\title{
The effects of phosphodiesterase inhibition on memory
}

Citation for published version (APA):

Rutten, K. (2007). The effects of phosphodiesterase inhibition on memory. [Doctoral Thesis, Maastricht University]. Universiteit Maastricht. https://doi.org/10.26481/dis.20070530kr

Document status and date:

Published: 01/01/2007

DOI:

10.26481/dis.20070530kr

Document Version:

Publisher's PDF, also known as Version of record

\section{Please check the document version of this publication:}

- A submitted manuscript is the version of the article upon submission and before peer-review. There can be important differences between the submitted version and the official published version of record.

People interested in the research are advised to contact the author for the final version of the publication, or visit the DOI to the publisher's website.

- The final author version and the galley proof are versions of the publication after peer review.

- The final published version features the final layout of the paper including the volume, issue and page numbers.

Link to publication

\footnotetext{
General rights rights.

- You may freely distribute the URL identifying the publication in the public portal. please follow below link for the End User Agreement:

www.umlib.nl/taverne-license

Take down policy

If you believe that this document breaches copyright please contact us at:

repository@maastrichtuniversity.nl

providing details and we will investigate your claim.
}

Copyright and moral rights for the publications made accessible in the public portal are retained by the authors and/or other copyright owners and it is a condition of accessing publications that users recognise and abide by the legal requirements associated with these

- Users may download and print one copy of any publication from the public portal for the purpose of private study or research.

- You may not further distribute the material or use it for any profit-making activity or commercial gain

If the publication is distributed under the terms of Article $25 \mathrm{fa}$ of the Dutch Copyright Act, indicated by the "Taverne" license above, 


\section{The Effects of Phosphodiesterase INHIBITION ON MEMORY}

Kris Rutten 
Kris Rutten, Maastricht, 2006

Coverdesign by Jim Rutten (www.jamesdesign.nl)

Typesetting by Michal Slawinski

ISBN 978-90-9021867-0

Printed in Poland 


\title{
The Effects of Phosphodiesterase INHIBITION ON MEMORY
}

\author{
Proefschrift
}

Ter verkrijging van de graad van doctor aan

de Universiteit Maastricht, op gezag

van de Rector Magnificus, Prof. Mr. G.P.M.F. Mols, volgens het besluit van het College van Decanen, in het openbaar te verdedigen op woensdag 30 mei 2007 om 14.00 uur.

door

Kris Rutten

Geboren op 18 september 1980 te Kerkrade 


\section{Promotor}

Prof. Dr. H.W.M. Steinbusch

\section{Co-promotor}

Dr. A. Blokland

\section{Beoordelingscomissie:}

Prof. Dr. W.J. Riedel

Prof. Dr. R. D’Hooge (Université de Liège, Belgium)

Dr. R. Scheiber (Sepracor Inc, USA)

Prof. Dr. J. Smits

Dr. J. de Vente 
If any one faculty of our nature may be called more wonderful then the rest, I do think it is memory. There seems something more speakingly incomprehensible in the powers, the failures, the inequalities of memory, than in any other of our intelligences. The memory is sometimes so retentive, so serviceable, so obedient at others, so bewildered and so weak - and at others again, so tyrannic, so beyond control! - We are to be sure a miracle every way - but our powers of recollecting and forgetting, do seem peculiarly past finding out.

Jane Austen, Mansfield Park, 1961 
The publication of this thesis was financially supported by

Böhringer Ingelheim $\mathrm{GmbH}$

Lilly Research Laboratories, UK

Noldus Information Technology B.V.

Novartis B.V.

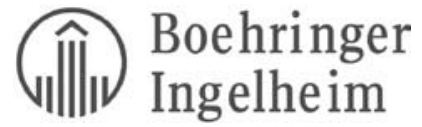

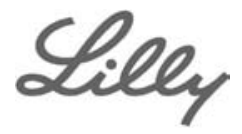

Noldus

(1) NOVARTIS 


\section{Contents}

1 General introduction

2 The Selective PDE5 inhibitor sildenafil improves object memory in Swiss mice and increase cGMP levels in hippocampal slices

3 Rolipram reverses scopolamine-induced and time-dependent memory deficits in object recognition by different mechanisms of action

4 Time-dependent involvement of cAMP and cGMP in consolidation of object memory: studies using selective phosphodiesterase type 2, 4 and 5 inhibitors

5 The PDE4 inhibitor rolipram reverses object memory impairment induced by acute tryptophan depletion in the rat

6 Behavioral effects of PDE4-D and PDE4-B knock-out mice in models of learning and memory

7 Selective PDE inhibitors sildenafil and rolipram improve object retrieval performance in unimpaired adult Cynomolgus macaques

8 General discussion

9 Summary

10 Samenvatting

11 Dankwoord

12 Publications

13 Curriculum vitae 


\section{ABbreviations}

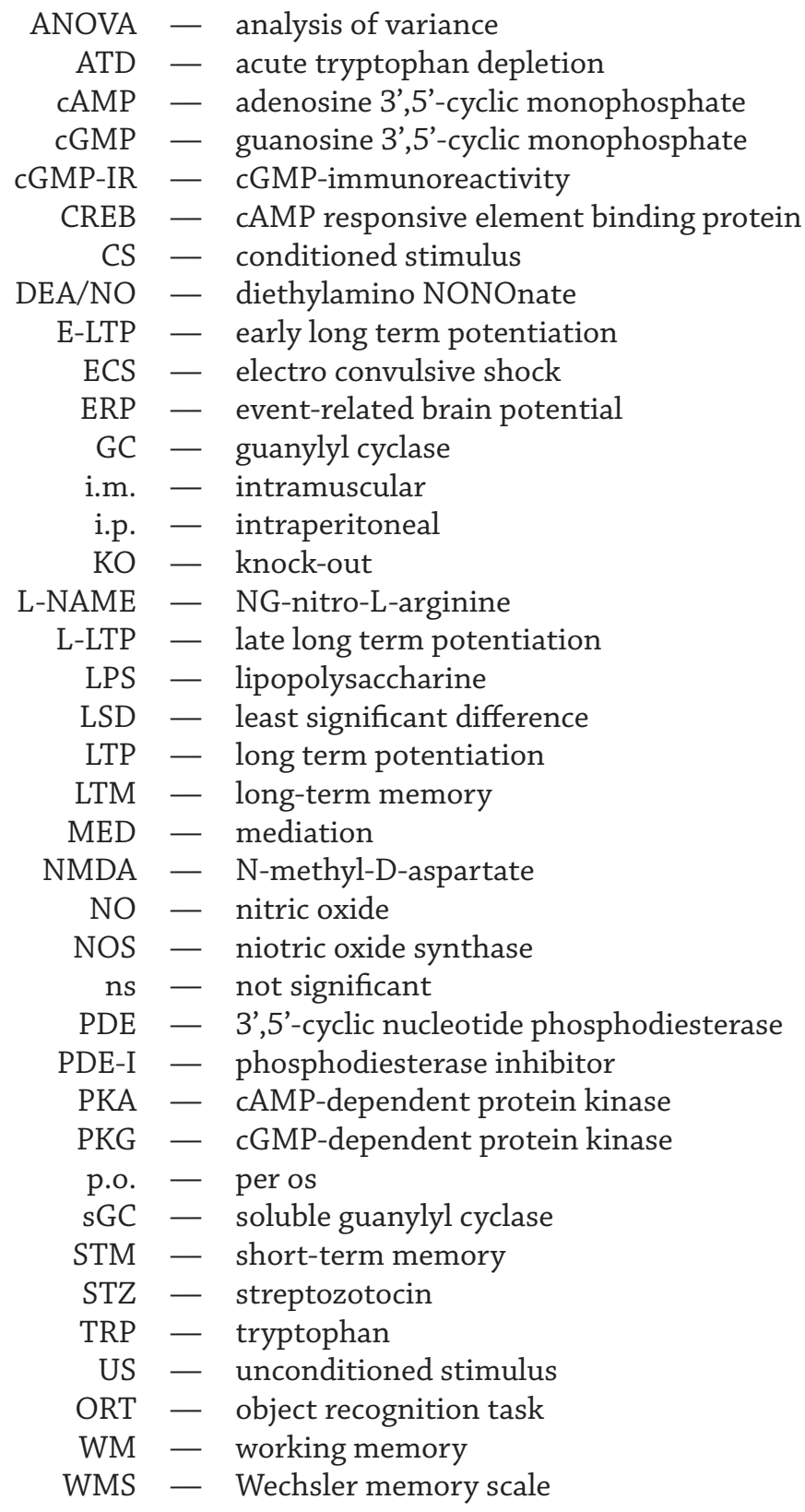




\section{GENERAL InTRODUCTION}




\section{GENERAL INTRODUCTION}

The memory system represents one of the most fundamental but also one of the most complex systems in the brain. Nearly all living organisms, from Drosophila to primates, exhibit some kind of learning and memory. Evolution has favored those organisms that learn from previous experience and found some way to store previous information for later use. The primitive mechanism of memory formation is believed to be comparable between species with regard to the underlying cellular mechanisms. Therefore, fundamental research using animal models of cognition in vivo or in vitro can realize better comprehension of the human memory system. Furthermore, pathological situations in which memory functioning is compromised provide valuable information about the memory system and its underlying mechanisms.

Memory impairment can occur as a result of normal aging or pathological conditions. Because life expectancy is increasing and the middle-aged cohort is greater than previous decades, the absolute number of old people will increase substantially. As a consequence of this double aging, the age-associated problems will increase. One of the more serious problems older people are facing is a decline in cognitive functions (Mattson et al. 2002). Memory impairments have a strong negative impact on the daily activities and quality of life of aged people. The loss of cognitive functioning is even more serious in pathological conditions such as Alzheimer's disease or other dementia. But also in depressed and schizophrenic patients, prominent memory deficits are present (Blaney 1986; Frith 1996). So far, several preventive strategies have been described which could ameliorate or slow down the cognitive decline resulting from brain aging. Research has focused on avoiding genetic and environmental factors that cause neuronal dysfunction and death or by enhancement of the ability of neurons to adapt to the aging process (Mattson et al. 2002). Examples of avoiding genetic factors are genetic counseling or germ line gene therapy and examples of avoiding environmental factors are dietary restrictions or behavioral modification. These strategies can induce successful ageing and can reduce the risk of cognitive decline and dementia (for a review see Mattson et al. 2002). Despite these strategies, there is a great need for drugs that counteract the processes involved in ageing and more specifically the decline of cognitive functions and memory.

For the enhancement of memory or reversal of cognitive deficits different drug targets have been suggested based on neurotransmitter systems. Serotonergic, cholinergic and dopaminergic neurotransmitter systems have been shown to be involved in memory. Furthermore, cognitive performance, including memory, can be facilitated by numerous biological factors. Memory can be improved or impaired for example by neurotransmitters, neuromodulators, intracellular molecules, hormones, plant extracts and nutritional ingredients (Cahill et al. 1994; Davis and Squire 1984; DeZazzo and Tully 1995; Izquierdo et al. 1998; McGaugh 1989; Messier 2004).

A still relatively novel and promising field in memory research focuses on the involvement of second messenger systems. Inhibition of phosphodiesterase (PDE) enzymes is a way 
to enhance second messenger signaling and consequently influence the pathways involved in learning and memory. A more detailed description of the different PDEs is given later.

In this thesis the effects of PDE inhibition (PDE-I) on memory are investigated in different animal models of cognition. PDE-I in mice, rats and monkeys is studied as well as the temporal effects of PDE-I. Studies were conducted to asses the effects of PDE-I on intact memory as well as deficit memory models. In general, the effects of cyclic adenosine monophosphate (cAMP) and cyclic guanosine monophosphate (cGMP) manipulations were studied on learning and memory by means of inhibition of specific PDEs.

\section{Memory systems}

There are several ways of classifying memory, based on the duration of storage (temporal basis), the nature (structure), and the physical domain of information to be stored. In Fig. 1 a schematic representation of the temporal and structural basis of memory is presented.

\section{Duration of storage}

A basic and generally accepted classification of memory is based on the duration of memory retention. This classification identifies three distinct types of memory: sensory store, shortterm memory, and long-term memory. In the sensory store, all the incoming information from the sensory organs is accumulated and by the process of attention certain items can be transferred to working memory. Sensory memory is characterized by the duration of memory retention which ranges from milliseconds up to $3 \mathrm{~s}$, whereas short-term memory can store information up to $15 \mathrm{~s}$. These stores generally have limited capacity and duration. However, stored information can be retrieved in a period of time which ranges from days to years; this type of memory is called long-term memory.

Short-term storage has also been referred to as working memory (Baddeley 2003). To store an item in long-term memory there is a transitional phase of consolidation. It is suggested that there are two stages for storing new information, i.e a early and a late consolidation (Ng et al. 1991; Prickaerts et al. 2004). It may be that short-term memory is supported by transient changes in neuronal communication, whereas long-term memories are maintained by more stable and permanent changes in neural structure that are dependent on protein synthesis.

\section{Nature of information}

Long-term memory can be divided into declarative (explicit) and procedural (implicit) memories (Squire et al. 1993; Zola-Morgan and Squire 1993). Declarative memory requires conscious recall, i.e. a conscious process to call back the information. It is sometimes called explicit memory, since it consists of information that is explicitly stored and retrieved. Declarative memory can be further sub-divided into semantic memory, which concerns facts 
taken independent of context; and episodic memory, which concerns information specific to a particular context, such as a time and place. In contrast, procedural memory (or implicit memory) is not based on the conscious recall of information, but on implicit learning (Schacter 1987). Procedural memory is primarily employed in learning motor skills and should be considered a subset of implicit memory.

\section{Physical domain of information}

The information stored in the memory system can also be classified based on its representative domain. Some examples of these domains are the visual, auditory, tactile, olfactory or spatial domain. Memory for a spatial location or a spatial map is stored in different cortical areas then for example the memory of faces. Specific lesions of the cortex can lead to impairment in the capability to recognize faces, prosopagnosia, whereas other memory functions remain unaffected.

\section{Measuring memory in behavioral experiments.}

In humans it is fairly easy to measure specific aspects of memory performance. Memory tests can be designed and subjects can be given specific instructions to perform optimally the test. To test memory performance in humans countless tests are available, and stan-

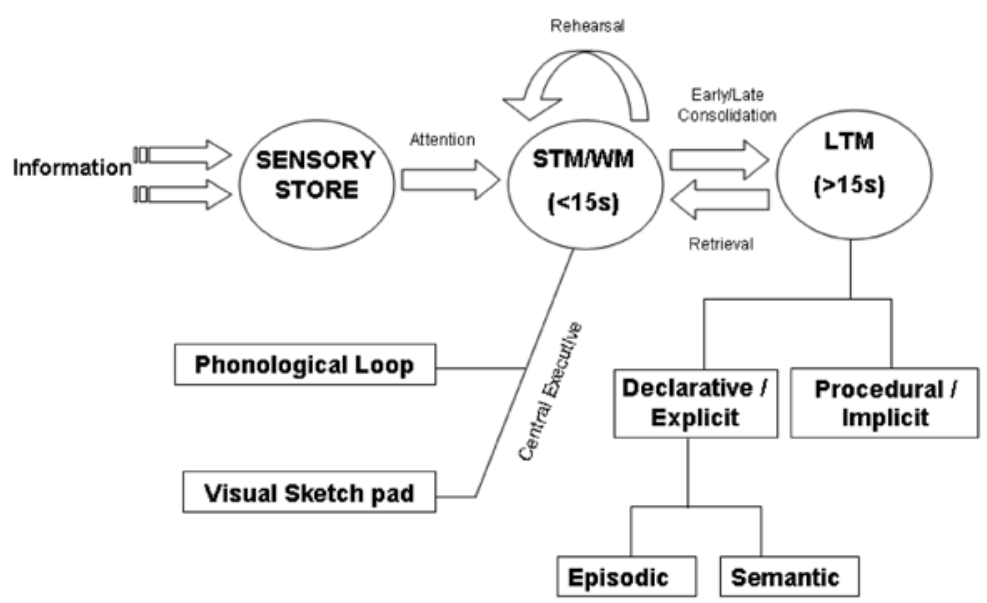

Figure 1: Schematic representation of the temporal features of memory and the nature of information. Forgetting can occur in the STM/ WM due to not attending to the new information. Forgetting can also occur in the LTM. Information can be transferred from STM to LTM after rehearsal by the process of consolidation. The working memory, according to Baddeley (2003) is composed of two parallel systems which are supervised by the Central Executive. These systems are only defined for humans. The long-term memory can be divided in different subsystems. The declarative memory system represents facts of a subject and the non-declarative system hold information about skills. The episodic memory is information that is unique for each individual subject whereas the semantic memory is information of general knowledge. STM: Short-term memory; WM: Working memory; LTM: Long-term memory. 
dardized batteries of memory tests are usually constructed so that all of the modalities of memory can be tested. Examples of these memory testing batteries are the Wechsler Memory Scale (WMS-I or WMS-II), Wechsler Memory Scale revised (WMS-R), Randt memory test or Guild Memory Test (for review see Lezak 1995).

In animal research testing memory function is not as straightforward, i.e. the predictive value of animal memory (i.e. does the outcome of the animal test predict the outcome in humans) and construct validity (i.e. does the test measure what it is supposed to measure) is more difficult. In respect to face validity, when studying memory processes in nonhuman subjects no instructions can be given and behavioral tests should therefore be designed in such a way that the animal's behavior directly reflects certain aspects of memory. In addition, several factors can be confounders in such tests, i.e. memory tests can be influenced among others by attention, motivation or anxiety-related behavior. Nevertheless several reliable memory tests, that investigate specific domains of memory, have been designed for memory assessment in nonhuman subjects. Box 1 gives an overview of the rodent memory tests used in the behavioral research described in this thesis. The examples of human and animal memory tests given above are not exhaustive and there are many more examples to be given. However it reaches beyond the scope of the present thesis to give a further detailed description of all these tests.

To assess the effects of possible pro-cognitive compounds, drugs can be tested in various behavioral test paradigms. A compound can be evaluated in healthy animals, in age impaired animals but also in genetic or drug induced disease models. A well known model for memory impairment is the scopolamine model (Bartus et al. 1985; Ebert and Kirch 1998). The anticholinergic agent scopolamine has shown to impair memory in several behavioral tests and is widely used to evaluate whether a novel compound is able to reverse the scopolamine deficit. In the present thesis we evaluated the effect of a PDE-I in the scopolamine model in the ORT. Another model that has shown to impair memory in both humans and rodents is acute tryptophan depletion (Lieben et al. 2005a; Lieben et al. 2004c; Park et al. 1994; Riedel et al. 1999; Sambeth et al. in press; Schmitt et al. 2000). In this model subjects are administered a diet that contains all essential amino acids except for tryptophan, the precursor of serotonin. The resulting tryptophan depletion in the blood causes a drop in brain tryptophan and consequently in central serotonin levels. These effects of acute tryptophan depletion are associated with impaired memory performance, especially consolidation of episodic memories. In this thesis we further investigated the acute tryptophan depletion model and tried to reverse its memory deficit with a PDE4-I.

Genetic modified or transgenic rats and mice are also often used to study mechanisms of pathology and basic brain functions. To evaluate the effects of the knockout of specific isoforms of the PDE4 gene we investigated two transgenic mouse strains. PDE4$B$ and PDE4-D mice were tested in a fear conditioning paradigm and a spatial water maze test. All these experiments add to the better understanding of the role of PDEs in learning and memory. 
Box 1: Behavioral tests used in this thesis for measuring learning and memory in rodents

Object Recognition Test: (Ennaceur and Delacour 1988)

In the training trial an animal is allowed to explore two similar objects in an arena. After a delay, usually 1 to $48 \mathrm{~h}$, the animal is re-exposed to the arena but this time with one familiar and one novel object. The times exploring the object are scored by an observer. When the animal remembers the familiar object it will spend more time exploring the novel object. This task is thought to be dependent on the hippocampus and rhinal cortex.

Fear Conditioning Test: Contextual and cue

Animals are placed in a testing chamber and allowed to acclimate for $2 \mathrm{~min}$. In the training trial an animal is subjected to one or more pairings of cue (i.e. tones, lights, the conditioning stimulus, CS) for about $30 \mathrm{~s}$ immediately followed by a noxious stimulus (i.e. a foot shock, the unconditioned stimulus, US). In the test session, usually $24 \mathrm{~h}$ later the animal is returned to the chamber for $5 \mathrm{~min}$ and no conditioning stimuli are presented. During the context test trial freezing behavior is measured (no movement except for breathing) which implicates the learned association between the foot shocks and the testing chamber. In the cue test, the animal is placed in a different chamber and is allowed to acclimate for $2 \mathrm{~min}$ after which it is exposed to the CS again for $3 \mathrm{~min}$. The difference in freezing behavior before and during the CS reflects the learned association of the CS (tone) and the foot shock. Both hippocampus and amygdala are involved in contextual fear conditioning, whereas cue conditioning is dependent on only the amygdala (LeDoux 2000).

\section{Water Escape Test (Morris 1984)}

Animals are exposed to a large (diameter about $2 \mathrm{~m}$ for rats and $1 \mathrm{~m}$ for mice) circular tank filled with water. Over several training sessions, animals learn the location of a submerged platform to escape the water. Based on external spatial cues the animals navigate the tank to find the platform that is placed at a fixed location. Swimming speed, escape latency and distance swum are calculated and are a measure for spatial learning. After (usually $24 \mathrm{~h}$ ) the learning trials a retention test can be applied in which the platform is removed from the tank and the time spent in the quadrant of the tank were the platform used to be is a measure for spatial memory retrieval. This task is believed to be hippocampus dependent, although the amygdala might also have a relevant role in successful spatial learning.

\section{Phosphodiesterases:}

Phosphodiesterases (PDEs) are enzymes that break down cyclic nucleotides, i.e. cAMP or cGMP. The family of PDEs is large and thus far eleven classes have been identified based on their substrate. PDEs can be selective for either cAMP or cGMP or both and these nucleotides play an important role in intracellular signaling and in processes of neuroplasticity, such as long term potentiation (LTP) (Frey et al. 1993b; Son et al. 1998). The difference be- 
tween PDE-Is as cognition enhancers and more conventional drugs is that most other drugs act on specific neurotransmitter systems whereas PDE-Is can modulate multiple biochemical systems through second messenger signaling. PDE-Is elevate concentrations of second messengers (cAMP and/or cGMP) which in turn trigger various intracellular mechanisms. As such, these second messengers are thought to be involved in processes of synaptic plasticity through the mechanism of LTP (Frey et al. 1993b; Impey et al. 1996b). The next section will focus on LTP and the role of PDEs in this process.

Table 1: Overview and properties of known enzymes of the cyclic nucleotide phosphodiesterases.

\begin{tabular}{|c|c|c|c|c|c|}
\hline Type & $\begin{array}{l}\text { Number } \\
\text { of Genes }\end{array}$ & Localization & Description & Substrate & $\begin{array}{l}\text { Selective } \\
\text { Inhibitors }\end{array}$ \\
\hline PDE1 & 3 & $\begin{array}{l}\text { brain, heart, smooth } \\
\text { muscle }\end{array}$ & $\begin{array}{l}\mathrm{Ca} 2+-\mathrm{CaM} \\
\text { stimulated }\end{array}$ & cAMP/cGMP & $\begin{array}{l}\text { calimidazolium, phenethiazines, } \\
\text { vinpocetine, SCH51866 }\end{array}$ \\
\hline PDE2 & 1 & $\begin{array}{l}\text { brain, heart, adrenal } \\
\text { cortex }\end{array}$ & cGMP stimulated & cAMP/cGMP & EHNA, Bay 60-7550 \\
\hline PDE3 & 2 & $\begin{array}{l}\text { brain, heart, smooth } \\
\text { muscle, adipose } \\
\text { platelets }\end{array}$ & cGMP inhibited & CAMP & $\begin{array}{l}\text { Amrinone, bucladesine, enoximone, } \\
\text { cilostamide, milrinone, SK\&F } 95654\end{array}$ \\
\hline PDE4 & 4 & ubiquitous & cAMP specific & CAMP & $\begin{array}{l}\text { rolipram, rofluminast, Ariflo, } \\
\text { MEM1018, MEM1091, HT0712 }\end{array}$ \\
\hline PDE5 & 1 & $\begin{array}{l}\text { brain, lung, platelets, } \\
\text { smooth muscle }\end{array}$ & cGMP specific & cGMP & $\begin{array}{l}\text { zaprinast, sildenafil, vardenafil, } \\
\text { tadelafil, SK\&F } 96231\end{array}$ \\
\hline PDE6 & 4 & $\begin{array}{l}\text { rod and cones photo } \\
\text { receptor }\end{array}$ & Photoreceptor & cGMP & (sildenafil, vardenafil) \\
\hline PDE7 & 2 & $\begin{array}{l}\text { brain, skeletal muscle, } \\
\text { kidney, T-cells, liver, } \\
\text { testis }\end{array}$ & $\begin{array}{l}\text { CAMP high } \\
\text { affinity }\end{array}$ & CAMP & $?$ \\
\hline PDE8 & 2 & $\begin{array}{l}\text { brain, liver, testis, } \\
\text { ovary }\end{array}$ & $\begin{array}{l}\text { CAMP high } \\
\text { affinity }\end{array}$ & CAMP & Dipyridamole \\
\hline PDE9 & 1 & brain, kidney & $\begin{array}{l}\text { cGMP high } \\
\text { affinity }\end{array}$ & cGMP & BAY 73-6691 \\
\hline PDE10 & 1 & brain, testis & cAMP-inhibited & cGMP & $?$ \\
\hline PDE11 & 1 & $\begin{array}{l}\text { skeletal muscle, kid- } \\
\text { ney, liver, pituitary }\end{array}$ & Dual substrate & cAMP/cGMP & (tadelafil) \\
\hline
\end{tabular}

Note that the list of tissues in the localization column is not exhaustive.

\section{Long term potentiation}

Long term potentiation (LTP) is a process in the brain that can explain certain aspects of synaptic plasticity. LTP is the increase in the chemical strength of a synapse after a tetanus stimulation that lasts for over an hour. Experimentally, a series of short, high frequency electric stimulation to a nerve cell synapse can strengthen, or potentiate, that synapse for minutes to hours. Hippocampal LTP has been proposed to be a neurophysiological correlate of memory (Bliss and Collingridge 1993). Studies that investigated the underlying molecular mechanisms of LTP have provided molecular 
tools for improving LTP and consequently memory. Among the various molecules involved in LTP, cAMP and cGMP play a prominent role (Bailey et al. 1996a; Chien et al. 2003; Son et al. 1998).

In general, LTP is often divided into two phases, an early phase (E-LTP), which is short lasting and a late phase (L-LTP), that lasts longer and depends on gene transcription and protein synthesis (Pang and Lu 2004; Voronin et al. 1995).

\section{Early LTP}

In general, E-LTP can be experimentally induced in the CA1 area of the hippocampus by applying a couple trains of tetanic stimulation to the synaptic connection between two neurons. E-LTP is typically induced by one or two trains of $100 \mathrm{~Hz}, 1$ s stimulation separated by $20 \mathrm{~s}$ (Lu and Hawkins 2002). This form of LTP lasts less than $3 \mathrm{~h}$ and requires no gene transcription or protein synthesis. Shortly, the induction process of E-LTP involves the activation of NMDA receptors, a subclass of glutamate receptors. Post-synaptic depolarization after short tetanus stimulation removes the voltage-dependent magnesium block of NMDA receptors. This results in an influx of $\mathrm{Ca} 2+$ through the NMDA receptor in the post-synaptic neuron (Pang and Lu 2004). Elevated intracellular Ca2+ levels trigger a cascade of reactions including the production of Nitric Oxide (NO) and activation of the Ca2+-calmodulin-dependent protein kinase II (CaMKII). Initially, cGMP was thought to act mainly pre-synaptically in the E-LTP as part of a NO/sGC/cGMP pathway. In this respect $\mathrm{NO}$ is regarded as a retrograde messenger. Elevation of cGMP could result in either more glutamate release via activation of pre-synaptic voltage-gated cGMP-dependent ion channels, or more glutamate synthesis via cGMP-dependent protein kinase (PKG). However, post-synaptic mechanisms of action are also suggested, via the insertion of post-synaptic AMPA receptors by activation of CaMKII (Lu and Hawkins 2002).

\section{Late LTP}

In the CA1 area of the hippocampus, L-LTP can be experimentally induced by a series of three or more trains of tetanic stimulation spaced roughly $10 \mathrm{~min}$ apart. L-LTP is typically induced by three or four trains of stimulation separated by 5-10 min. In contrast to E-LTP, LLTP requires activation of CAMP-dependent protein kinase (PKA) and results in synthesis of RNA and proteins (Lu and Hawkins 2002). Therefore, L-LTP has been proposed as a possible molecular analogue of long-term memory. Several pathways might be involved in L-LTP. cAMP response element binding protein (CREB) is thought to be the primary transcription factor in the cascade of gene expression that leads to permanent structural changes at the level of the synapse (Impey et al. 1996b).

Recently, it has been shown that a cGMP/PKG/CREB pathway is also involved in L-LTP (Lu and Hawkins 2002; Lu et al. 1999). Thus, cAMP and cGMP play an important role in intracellular signaling and in processes of neuroplasticity such as long term potentiation (LTP) (see Fig 2). 


\section{Pre-synaptic $\longrightarrow$ Post-synaptic}

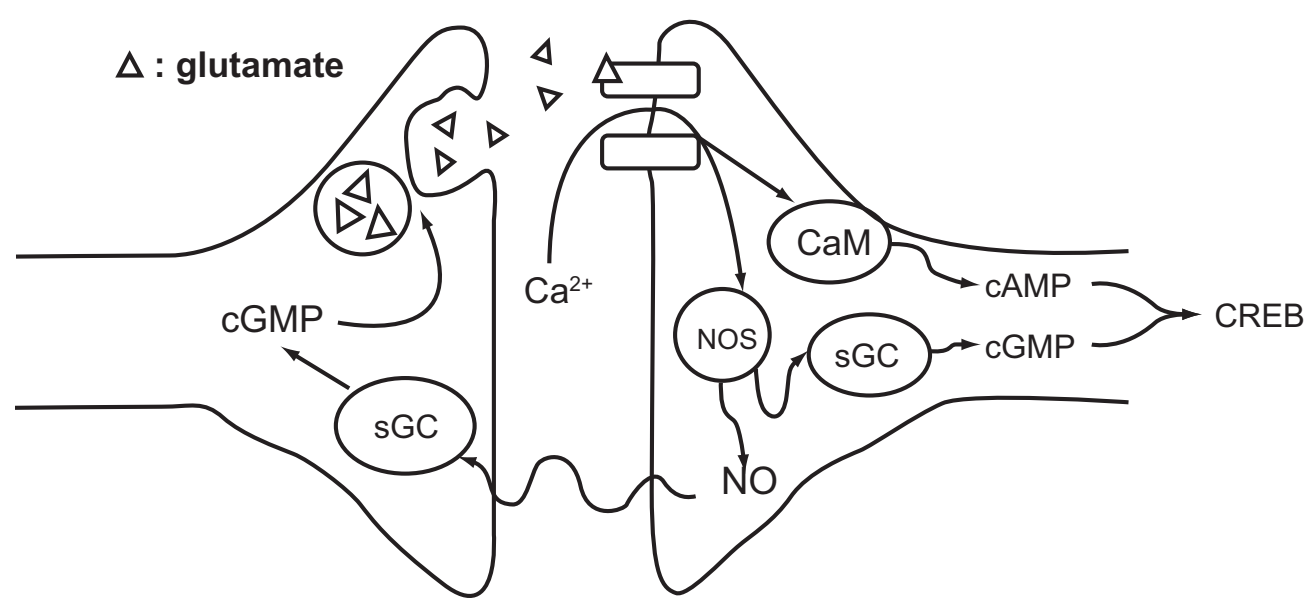

Figure 2: Simplified diagram of involvement of cGMP and cAMP in long-term potentiation (LTP). After the release of glutamate from the pre-synaptic neuron, it binds to AMPA and NMDA receptors. If the signal is strong enough, calcium (Ca2+) will enter the post-synaptic neuron through the NMDA receptor and activates calmodulin ( $\mathrm{CaM}$ ) which in turn stimulates adenylate cyclase (AC). Subsequently, cAMP is synthesized, which can lead to protein synthesis via activation of cAMP-response element binding protein (CREB). Besides activation of $\mathrm{CaM}, \mathrm{Ca} 2+$ activates constitutive nitric oxide synthase (NOS). After activation of NOS the gaseous molecule nitric oxide (NO) is formed, and it can have a dual action. First, NO can diffuse back to the pre-synaptic region and activate soluble guanylate cyclase (sGC). cGC increases cGMP levels which in turn can potentiate the release of glutamate. A second action of NO is the activation of sGC post-synaptically. This can also lead to protein synthesis (through the activation of CREB). These phenomena, including other molecular events, are generally assumed to underlie LTP. PDEs break down cGMP and cAMP. Selective PDE inhibitors can therefore increase cGMP levels pre-synaptically and/or increase cAMP and cGMP levels post-synaptically.

\section{PDE inhibition and LTP}

Two key players in LTP processes are the cyclic nucleotides cAMP and cGMP, because they play an important role in intracellular signaling (Bailey et al. 1996a; Chien et al. 2003; Son et al. 1998). Therefore the hypothesis that PDE inhibition could enhance memory through the process of LTP arose and several studies have been performed to investigate this possibility. A couple of very important studies provided the base for some of the behavioral experiments described in this thesis. These previous studies showed that intra-hippocampal infusion of 8Br-cAMP improved memory performance when injected 3 or $6 \mathrm{~h}$ after one-trial training, but not when injected directly after the training trial. In contrast, intra-hippocampal injections with 8Br-cGMP only improved memory performance when injected directly after the learning trial and not when injected $3 \mathrm{~h}$ or $6 \mathrm{~h}$ later (Bernabeu et al. 1997b; Bernabeu et al. 1996; Prickaerts et al. 2002a). The time dependent effects of cAMP and cGMP in memory performance may underlie different cellular mechanisms and we speculated that these mechanisms might be related to early and late consolidation processes. 


\section{Effects of PDE-I on cognition}

Many different classes of PDEs exists (See Table 1) and most of them are expressed in the brain (except for PDE6 and PDE11). By far, not all classes of PDEs have selective inhibitors and if they do then these cannot always cross the blood-brain barrier. For the scope of the present thesis three PDE-Is are of importance, namely PDE2-I, PDE4-I and PDE5-I. These inhibitors are widely available, can be administered peripherally and show central effects. The next section will focus on these three PDE-I and their effects on cognition. Of note, to our knowledge these are the only PDE-Is to have ever been tested in learning and memory research.

\section{Effects of PDE2-I on cognition}

PDE2 hydrolyses both cAMP and cGMP. Thus far, only a few studies have been published that investigated the effects of PDE2 inhibition in behavioral models. To our knowledge, BAY 60-7550 is the only selective PDE2 inhibitor which has been tested in learning and memory models (Boess et al. 2004; Rutten et al. 2006c). In vitro experiments showed that this compound increases both cAMP and cGMP levels in cortical neurons and hippocampal fibers (Boess et al. 2004).

\section{Recent findings}

Different behavioral tests were used to characterize the effects of Bay 60-7550 on memory performance (Boess et al. 2004). At a dose of $3 \mathrm{mg} / \mathrm{kg}$ (p.o.) Bay 60-7550 fully antagonized the spatial WM deficit in a T-maze after treatment with the NMDA antagonist dizocilpine (MK-801, $0.04 \mathrm{mg} / \mathrm{kg}$, i.p.).

When given immediately after training in tasks of object or social recognition, Bay 60-7550 improved object recognition in both rats ( 1 and $3 \mathrm{mg} / \mathrm{kg}$, p.o.) and mice (0.3 and $1 \mathrm{mg} / \mathrm{kg}$, p.o). Likewise, social recognition was improved in rats ( 1 and $3 \mathrm{mg} / \mathrm{kg}$, p.o.) as well as mice (0.6, 2 and $6 \mathrm{mg} / \mathrm{kg}$, p.o.). These effects of BAY 60-7550 on early consolidation processes may be mainly mediated by cGMP and not cAMP, since cGMP, but not cAMP, injections into the hippocampus immediately after training improved LTM in tasks of object recognition and passive avoidance learning. In the present thesis the effect of BAY 60-7550 (3 mg/kg, p.o.) on object recognition memory was further investigated, in particular the effect of time of treatment was studied (chapter 4).

\section{The effects of PDE4-I on cognition}

Ample evidence supports a role for the cAMP/PKA/CREB pathway in learning and memory processes (Barco et al. 2003; Tully et al. 2003). PDE4 inhibitors specifically inhibit cAMP and the underlying mechanism for their cognitive-enhancing effects may involve modulation of activity within the cAMP/PKA/CREB pathway (Imanishi et al. 1997; Nagakura et al. 2002). 
In the literature most studies use the prototypical PDE4 inhibitor, rolipram, to examine the effects of PDE4-I on memory (Table 2 for an overview). Furthermore, rolipram has good brain penetration and a relatively short half-life of 1-3 h(Krause and Kuhne 1988). Hippocampal slices treated with rolipram in vitro, showed that cAMP levels were increased (Barad et al. 1998; van Staveren et al. 2001). One of the perceived liabilities of rolipram is emesis (i.e. nausea), and second generation PDE4 inhibitors such as cilomilast (Ariflo ${ }^{\circledR}$ ) and roflumilast are thought to be less emetic. But these newer PDE4 inhibitors have been developed for peripheral indications, such as respiratory disorders (COPD), and so far no data have been published regarding their activity in memory models. Four new PDE4 inhibitors have recently been reported in the literature or presented at meetings: MEM1018, MEM1091, MEM1414 and HT0712; (Bourtchouladze et al. 2003; Trippodi and Rose 2002; Zhang et al. 2005). The review by Blokland et al (2006) gives an extensive review of the literature on PDE4-I and memory. The following section will add the latest recent studies from the literature and some studies presented in this thesis that add to the growing literature on PDE4-I and cognitive enhancement.

\section{Recent findings}

Apart from the studies of rolipram and HT0712 on short-term and long-term memory, a recent study by Zhang et al. (2005) showed memory enhancing effects of two novel PDE4 inhibitors MEM 1018, MEM 1091. In this study it was shown that these selective PDE4 inhibitors ameliorated the behavioral deficits caused by the NMDA receptor antagonist MK801 in the radial arm maze and the inhibitory avoidance test. These effects are likely to be caused by an enhancement of cAMP-mediated signaling in the brain (Zhang et al. 2005).

Furthermore, a novel study by Monti et al. (2005) for the first time showed behavioral effects after chronic rolipram treatment. Rolipram was administered through osmotic minipumps for 7 days and animals were tested in fear conditioning afterwards. Chronic rolipram treatment enhanced retention and slowed down extinction of conditioned fear. In addition hippocampal CREB and Arc were activated in slices after chronic rolipram treatment (Monti et al. 2006). These studies again show the involvement of cAMP, through PDE4 inhibition, in processes of synaptic plasticity and learning and memory.

Reviewing the available literature on rolipram there seemed to be a lack of a systematic and profound evaluation of the effects of PDE4 inhibition on acquisition, consolidation and retrieval of LTM. In the present thesis several experiments were carried out to elucidate some issues on the effects of rolipram on short-term and long-term memory and the processes of acquisition and consolidation in particular. Furthermore, we investigated the effects of PDE4-I in non-human primates. An overview of the available literature on the effects of PDE4-I on learning and memory is given in Table 2, which is an adapted and updated version of the overview in Blokland et al (2006). Results of the studies presented in this thesis were left out of the Table. 
To our knowledge, the effects of PDE4-Is on learning and memory performance have not been tested in human studies yet. A possible explanation for this might be that the most used PDE4-I in behavioral studies, rolipram, produces severe emetic side effects in humans. Novel PDE4-Is are thought to produce less negative side effects, but thus far no human memory studies have been reported.

Table 2: Effects of PDE4 inhibitors on learning and memory processes

\begin{tabular}{|c|c|c|c|c|}
\hline $\begin{array}{c}\text { Task } \\
\text { (memory process) }\end{array}$ & $\begin{array}{c}\text { Model } \\
\text { (species) }\end{array}$ & Treatment & Results & Reference \\
\hline $\begin{array}{c}\text { Morris water maze } \\
\text { (spatial, hippocampus- } \\
\text { dependent) }\end{array}$ & $\begin{array}{c}\text { Microsphere embo- } \\
\text { lism-induced cerebral } \\
\text { ischaemia } \\
\text { (rat) }\end{array}$ & $\begin{array}{c}\text { rolipram } 3 \text { mg/kg, ip, } \\
10 \text { days, after embolism }\end{array}$ & $\begin{array}{l}\text { Rolipram attenuates } \\
\text { acquisition deficit mea- } \\
\text { sured at days 7-9 }\end{array}$ & $\begin{array}{c}\text { (Nagakura et al. } \\
2002)\end{array}$ \\
\hline $\begin{array}{c}\text { Radial arm water maze } \\
\text { (spatial, hippocampus- } \\
\text { dependent) }\end{array}$ & $\begin{array}{l}\text { APP-PS1 Alzheimer } \\
\text { (mouse) }\end{array}$ & $\begin{array}{l}\text { rolipram } 0.1 \mathrm{uM} / \mathrm{kg} \\
\text { for } 3 \text { weeks }\end{array}$ & $\begin{array}{l}\text { Improvement wh en } \\
\text { tested at } 2 \text { months after } \\
\text { 3-week treatment }\end{array}$ & (Gong et al. 2004) \\
\hline $\begin{array}{c}\text { Barnes circular maze } \\
\text { (spatial, hippocampus- } \\
\text { dependent) }\end{array}$ & $\begin{array}{c}\text { Age-deficit } \\
\text { (18 months old mouse) }\end{array}$ & $\begin{array}{c}\text { rolipram } 0.016 \mathrm{mg} / \mathrm{kg} \text {, ip, } \\
40 \text { min before training }\end{array}$ & $\begin{array}{l}\text { More mice acquire the } \\
\text { task and number of er- } \\
\text { rors is reduced }\end{array}$ & (Bach et al. 1999) \\
\hline \multirow[t]{5}{*}{$\begin{array}{c}\text { Radial arm maze } \\
\text { (working \& reference } \\
\text { memory, hippocam- } \\
\text { pus-dependent) }\end{array}$} & $\begin{array}{c}\text { Scopolamine } 0.5 / 1.0 \mathrm{mg} / \\
\text { kg, ip, } \\
30 \text { min before test } \\
\text { (rat) }\end{array}$ & $\begin{array}{l}\text { rolipram } 0.01-1 \mathrm{mg} / \mathrm{kg} \text {, } \\
\text { ip, } 45 \mathrm{~min} \text { before test }\end{array}$ & $\begin{array}{l}\text { MED: } 0.1 \text { (working } \\
\text { memory) and >0.1 mg/ } \\
\text { kg (reference memory) }\end{array}$ & $\begin{array}{c}\text { (Zhang and } \\
\text { O'Donnell 2000) }\end{array}$ \\
\hline & $\begin{array}{c}\text { Scopolamine } 0.5 \mathrm{mg} / \mathrm{kg} \\
\text { ip, } 30 \mathrm{~min} \text { before test } \\
\text { (rat) }\end{array}$ & $\begin{array}{c}\text { ( } \pm \text { )-rolipram } \\
0.01-1 \mathrm{mg} / \mathrm{kg}, \mathrm{po} \\
\text { (-)-rolipram 0.005-1 mg/ } \\
\text { kg, po } \\
\text { (+)-rolipram (0.1-50 } \\
\mathrm{mg} / \mathrm{kg}, \mathrm{po})\end{array}$ & $\begin{array}{c}\text { MED (working memory): } \\
( \pm \text { )-rolipram } 0.02-0.2 \\
\mathrm{mg} / \mathrm{kg} \\
\text { (-)-rolipram } 0.01-0.02 \\
\text { and } 0.2 / 0.5 \mathrm{mg} / \mathrm{kg} \text { (bi } \\
\text { phasic) } \\
\text { (+)-rolipram } 20 / 50 \mathrm{mg} / \mathrm{kg}\end{array}$ & (Egawa et al. 1997) \\
\hline & $\begin{array}{c}\text { Glutamate antagonist } \\
\text { dizocilpine } 0.1 \mathrm{mg} / \mathrm{kg} \text {, ip, } \\
60 \text { min before test } \\
\text { (rat) }\end{array}$ & $\begin{array}{l}\text { rolipram } 0.01-0.1 \mathrm{mg} / \mathrm{kg} \text {, } \\
\text { ip, } 30 \mathrm{~min} \text { before test }\end{array}$ & $\begin{array}{l}\text { MED: } 0.05 \text { (working } \\
\text { memory) and } 0.1 \mathrm{mg} / \mathrm{kg} \\
\text { (reference memory) }\end{array}$ & (Zhang et al. 2000) \\
\hline & & $\begin{array}{c}\text { Rolipram } 0.1 \mathrm{mg} / \mathrm{kg}, \\
\text { MEM } 1018 \text { and MEM } \\
1091 \text { at } 0.1-2.5 \mathrm{mg} / \mathrm{kg} \text {, ip, } \\
45 \mathrm{~min} \text { before test }\end{array}$ & $\begin{array}{c}\text { MED: } 0.1 \mathrm{mg} / \mathrm{kg} \text { rolipram } \\
\text { working memory, } \\
\text { MED: } 2.5 \mathrm{mg} / \mathrm{kg} \text { MEM } \\
1018 \text { working and refer- } \\
\text { ence memory } \\
\text { MED: } 2.5 \mathrm{mg} / \mathrm{kg} \text { MEM } \\
1091 \text { on reference } \\
\text { memory. }\end{array}$ & (Zhang et al. 2005) \\
\hline & $\begin{array}{l}\text { MEK inhibitor UO126, } \\
8 \mathrm{ug} / \mathrm{rat} \text { into hippocam- } \\
\text { pus, given twice: } 60 \text { and } \\
30 \text { min before test (rat) }\end{array}$ & $\begin{array}{l}\text { Rolipram, 0.05, 0.1, mg/ } \\
\text { kg, ip, } 30 \text { min before test }\end{array}$ & $\begin{array}{c}\text { MED: } 0.1 \mathrm{mg} / \mathrm{kg} \text { (refer- } \\
\text { ence memory) }\end{array}$ & (Zhang et al. 2004a) \\
\hline \multirow[t]{2}{*}{$\begin{array}{l}\text { Passive avoidance } \\
\text { (inhibitory avoidance } \\
\text { learning, hippocam- } \\
\text { pus and amygdala } \\
\text { dependent) }\end{array}$} & $\begin{array}{c}\text { Scopolamine, } 3 \mathrm{mg} / \mathrm{kg} \text { ip, } \\
30 \text { min before retention } \\
\text { test } \\
\text { (rat) }\end{array}$ & $\begin{array}{l}\text { Given } 60 \text { min before } \\
\text { retention test. } \\
( \pm) \text {-rolipram 0.01- } \\
0.1 \mathrm{mg} / \mathrm{kg}, \text { po } \\
\text { (-)-rolipram } 0.005-0.02 \\
\mathrm{mg} / \mathrm{kg}, \text { po } \\
\text { (+)-rolipram } 0.3-10 \\
\mathrm{mg} / \mathrm{kg}, \text { po }\end{array}$ & 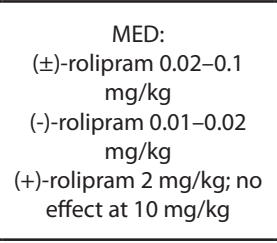 & (Egawa et al. 1997) \\
\hline & $\begin{array}{c}\text { Scopolamine, } 1.5 \mathrm{mg} / \mathrm{kg} \text {, } \\
\text { ip, immediately after } \\
\text { training } \\
\text { (mouse) }\end{array}$ & $\begin{array}{c}\text { Rolipram } 10 \text { and } 30 \\
\mathrm{mg} / \mathrm{kg} \text {, po, } 30 \text { min before } \\
\text { training }\end{array}$ & MED: 30 mg/kg & $\begin{array}{c}\text { (Ghelardini et al. } \\
\text { 2002) }\end{array}$ \\
\hline
\end{tabular}




\begin{tabular}{|c|c|c|c|c|}
\hline $\begin{array}{c}\text { Task } \\
\text { (memory process) }\end{array}$ & $\begin{array}{c}\text { Model } \\
\text { (species) }\end{array}$ & Treatment & Results & Reference \\
\hline & $\begin{array}{c}\text { Scopolamine, } 1 \mathrm{mg} / \mathrm{kg} \text {, ip } \\
30 \text { min before acquisition } \\
\text { (mouse) }\end{array}$ & $\begin{array}{l}\text { Rolipram, } 1-30 \mathrm{mg} / \mathrm{kg} \text {, ip, } \\
30 \mathrm{~min} \text { before acquisition }\end{array}$ & MED: $10 \mathrm{mg} / \mathrm{kg}$ & $\begin{array}{l}\text { (Imanishi et al. } \\
\text { 1997) }\end{array}$ \\
\hline & $\begin{array}{c}\text { Glutamate antagonist } \\
\text { dizocilpine } 0.1 \mathrm{mg} / \mathrm{kg}, \text { ip, } \\
60 \mathrm{~min} \text { before test } \\
\text { (rat) }\end{array}$ & $\begin{array}{l}\text { Rolipram } 0.1 \mathrm{mg} / \mathrm{kg} \text {, ip, } \\
30 \mathrm{~min} \text { before test }\end{array}$ & MED: $\leq 0.1 \mathrm{mg} / \mathrm{kg}$ & $\begin{array}{c}\text { (Zhang and } \\
\text { O'Donnell 2000) }\end{array}$ \\
\hline & & $\begin{array}{c}\text { Rolipram } 0.1 \mathrm{mg} / \mathrm{kg}, \text { MEM } \\
1018 \text { and MEM } 1091 \text { at } \\
0.1-2.5 \mathrm{mg} / \mathrm{kg} \text {, ip, } 45 \\
\text { min before test }\end{array}$ & $\begin{array}{c}\text { MED: Rolipram } 0.1 \mathrm{mg} / \mathrm{kg} \\
\text { MEM1018 } 0.1-2.5 \mathrm{mg} / \mathrm{kg} \\
\text { and MEM } 10910.5-2.5 \\
\mathrm{mg} / \mathrm{kg} \text { on reversal } \\
\text { latency }\end{array}$ & (Zhang et al. 2005) \\
\hline & $\begin{array}{l}\text { MEK inhibitor UO126, } \\
\text { 8ug/rat into hippocam- } \\
\text { pus, given twice: } 60 \text { and } \\
30 \text { min before test }\end{array}$ & $\begin{array}{c}\text { Rolipram, } 0.1, \mathrm{mg} / \mathrm{kg}, \mathrm{ip}, \\
30 \mathrm{~min} \text { before test or } 30 \\
\text { ug/rat into hippocampus, } \\
20 \text { min before test }\end{array}$ & $\begin{array}{l}\text { Reversal retention deficit } \\
\text { 48-h post training }\end{array}$ & (Zhang et al. 2004a) \\
\hline \multirow[t]{3}{*}{$\begin{array}{l}\text { 3-panel runway task } \\
\text { (working memory, hip- } \\
\text { pocampus- prefrontal } \\
\text { cortex dependent) }\end{array}$} & $\begin{array}{l}\text { Scopolamine, } 0.56 \\
\mathrm{mg} / \mathrm{kg} \text {, ip, } 15 \mathrm{~min} \text { before } \\
\text { first trial } \\
\text { (rat) }\end{array}$ & $\begin{array}{l}\text { Rolipram, } 0.032,0.1 \\
\mathrm{mg} / \mathrm{kg} \text {, ip, } 30 \mathrm{~min} \text { before } \\
\text { first trial }\end{array}$ & $\begin{array}{l}\text { MED: } 0.1 \mathrm{mg} / \mathrm{kg} \text { for } \\
\text { decrease errors }\end{array}$ & $\begin{array}{l}\text { (Imanishi et al. } \\
\text { 1997) }\end{array}$ \\
\hline & $\begin{array}{l}\text { Cerebral ischemia by } \\
\text { four-vessel occlusion } \\
\text { (rat) }\end{array}$ & $\begin{array}{l}\text { Rolipram, } 0.032,0.1 \\
\mathrm{mg} / \mathrm{kg}, \mathrm{ip}, 30 \text { min before } \\
\text { first trial (immediately } \\
\text { after reperfusion) }\end{array}$ & $\begin{array}{l}\text { MED: } 0.1 \mathrm{mg} / \mathrm{kg} \text { for } \\
\text { decrease errors }\end{array}$ & $\begin{array}{l}\text { (Imanishi et al. } \\
\text { 1997) }\end{array}$ \\
\hline & $\begin{array}{c}\text { ECS immediately after } \\
\text { training } \\
\text { (rat) }\end{array}$ & $\begin{array}{l}\text { Rolipram, } 0.1,0.32 \mathrm{mg} / \\
\text { kg, ip, just before ECS }\end{array}$ & $\begin{array}{l}\text { MED: } 0.32 \mathrm{mg} / \mathrm{kg} \text { for } \\
\text { decrease errors }\end{array}$ & $\begin{array}{l}\text { (Imanishi et al. } \\
\text { 1997) }\end{array}$ \\
\hline $\begin{array}{l}\text { Inhibitory avoidance } \\
\text { (hippocampus and } \\
\text { amygdala dependent) }\end{array}$ & $\begin{array}{l}\text { 1. Protein synthesis } \\
\text { inhibitor anisomycin, } 150 \\
\mathrm{mg} / \mathrm{kg} \text {, sc, } 30 \text { min before } \\
\text { training } \\
\text { 2. Low baseline } \\
\text { (mouse) }\end{array}$ & $\begin{array}{c}\text { Rolipram } 3,10 \mathrm{mg} / \mathrm{kg}, \\
\text { ip, immediately after } \\
\text { training or } 3 \text { hours after } \\
\text { training }\end{array}$ & $\begin{array}{l}\text { MED } 10 \mathrm{mg} / \mathrm{kg} \text {, given im- } \\
\text { mediately after training } \\
\qquad(1+2)\end{array}$ & (Randt et al. 1982) \\
\hline \multirow[t]{4}{*}{$\begin{array}{l}\text { Contextual fear-condi- } \\
\text { tioning } \\
\text { (hippocampus and } \\
\text { amygdala dependent) }\end{array}$} & $\begin{array}{l}\text { Unimpaired } \\
\text { (mouse) }\end{array}$ & $\begin{array}{l}\text { Rolipram } 0.03 \mathrm{mg} / \mathrm{kg}, \mathrm{sc} \\
30 \mathrm{~min} \text { before training }\end{array}$ & $\begin{array}{l}\text { Improved retention } 24 \mathrm{~h} \\
\text { after training }\end{array}$ & (Barad et al. 1998) \\
\hline & $\begin{array}{l}\text { Unimpaired } \\
\text { (rat) }\end{array}$ & $\begin{array}{c}\text { Rolipram } 0.5 \mathrm{mg} / \mathrm{kg} \text { per } \\
\text { day for } 7 \text { days chronic } \\
\text { delivery by osmotic mini- } \\
\text { pumps }\end{array}$ & $\begin{array}{c}\text { Improved memory } \\
\text { consolidation and slower } \\
\text { extinction of conditioned } \\
\text { fear }\end{array}$ & (Monti et al. 2006) \\
\hline & $\begin{array}{l}\text { Impaired TG2576 } \\
\text { Alzheimer mice } \\
\text { (mouse) }\end{array}$ & $\begin{array}{l}\text { Rolipram } 30 \mathrm{~min} \text { prior to } \\
\text { training at } 0.1 \mathrm{mg} / \mathrm{kg} \text { ip }\end{array}$ & $\begin{array}{l}\text { Improvement in mutants } \\
\text { and wild type }\end{array}$ & (Comery et al. 2005) \\
\hline & $\begin{array}{l}\text { APP-PS Alzheimer mice } \\
\text { (mouse) }\end{array}$ & $\begin{array}{c}\text { Rolipram } 0.1 \mathrm{uM} / \mathrm{kg} \text { for } \\
3 \text { weeks }\end{array}$ & $\begin{array}{l}\text { Improvement when } \\
\text { tested } 2 \text { months follow- } \\
\text { ing 3-week treatment }\end{array}$ & (Gong et al. 2004) \\
\hline \multirow[t]{2}{*}{$\begin{array}{c}\text { Novel object } \\
\text { recognition } \\
\text { (hippocampus and rhi- } \\
\text { nal cortex dependent) }\end{array}$} & Unimpaired young (rat) & $\begin{array}{l}\text { MEM1414 given: } \\
\text { 1. prior to training } \\
\text { 2. immediately after } \\
\text { training } \\
\text { 3. immediately prior to } \\
\text { testingrolipram }\end{array}$ & $\begin{array}{l}\text { Improvement when } \\
\text { given prior to or after } \\
\text { training }\end{array}$ & $\begin{array}{l}\text { (Trippodi and Rose } \\
\text { 2002) }\end{array}$ \\
\hline & $\begin{array}{c}\text { Unimpaired young and } \\
\text { aged } \\
\text { (rat) }\end{array}$ & $\begin{array}{c}\text { MEM1018 at } 0.05,0.5,5 \\
\mathrm{mg} / \mathrm{kg} \text {, ip }\end{array}$ & $\begin{array}{c}\text { MED: } \leq 0.05 \mathrm{mg} / \mathrm{kg} \\
\text { (young) and } 0.5 \mathrm{mg} / \mathrm{kg} \\
\text { (aged) }\end{array}$ & $\begin{array}{l}\text { (Trippodi and Rose } \\
\text { 2003) }\end{array}$ \\
\hline
\end{tabular}




\begin{tabular}{|c|c|c|c|c|}
\hline $\begin{array}{c}\text { Task } \\
\text { (memory process) }\end{array}$ & $\begin{array}{c}\text { Model } \\
\text { (species) }\end{array}$ & Treatment & Results & Reference \\
\hline & Unimpaired young (rat) & $\begin{array}{l}\text { Rolipram } 0.01,0.03 \text { and } \\
0.1 \mathrm{mg} / \mathrm{kg} \text { ip given: } \\
1.30 \mathrm{~min} \text { before training } \\
\text { 2. directly after training } \\
\text { 3. } 3 \mathrm{~h} \text { after training. }\end{array}$ & $\begin{array}{l}\text {-Results are presented in } \\
\text { present thesis- }\end{array}$ & $\begin{array}{c}\text { (Rutten et al. 2006b) } \\
\text { \& Chapter } 3\end{array}$ \\
\hline & Unimpaired young (rat) & $\begin{array}{c}\text { Rolipram } 0.03 \mathrm{mg} / \mathrm{kg} \text { ip. } \\
\text { Given: } \\
\text { 1. directly after training } \\
\text { 2. } 1 \mathrm{~h} \text { after training } \\
\text { 3. } 3 \mathrm{~h} \text { after training } \\
\text { 4. } 6 \mathrm{~h} \text { after training }\end{array}$ & $\begin{array}{c}\text {-Results are presented in } \\
\text { present thesis- }\end{array}$ & $\begin{array}{c}\text { (Rutten et al. 2006c) } \\
\text { \& Chapter } 4\end{array}$ \\
\hline & $\begin{array}{c}\text { Scopolamine }(0.1 \\
\mathrm{mg} / \mathrm{kg} \text {, i.p. } 30 \mathrm{~min} \text { before } \\
\text { training } \\
\text { (rat) }\end{array}$ & $\begin{array}{l}\text { Rolipram } 0.03,0 . \text { and } 0.3 \\
\mathrm{mg} / \mathrm{kg} \text {, i.p. } 30 \mathrm{~min} \text { before } \\
\text { training. }\end{array}$ & $\begin{array}{l}\text {-Results are presented in } \\
\text { present thesis- }\end{array}$ & $\begin{array}{c}\text { (Rutten et al. 2006b) } \\
\text { \& Chapter } 3\end{array}$ \\
\hline & $\begin{array}{c}\text { Acute Tryptophan Deple- } \\
\text { tion 3h before training } \\
\text { (rat) }\end{array}$ & $\begin{array}{c}\text { Rolipram } 0.03,0.1 \text { and } \\
0.3 \mathrm{mg} / \mathrm{kg} \text { ip } 30 \mathrm{~min} \\
\text { before training }\end{array}$ & $\begin{array}{c}\text {-Results are presented in } \\
\text { present thesis- }\end{array}$ & $\begin{array}{c}\text { (Rutten et al. in } \\
\text { press) \& Chapter } 5\end{array}$ \\
\hline & $\begin{array}{l}\text { Heterozygous CBP } \\
\text { mutants } \\
\text { (mouse) }\end{array}$ & $\begin{array}{l}\text { Rolipram } 0.1 \mathrm{mg} / \mathrm{kg}, \\
\text { ip; HT0712 } 0.001-0.5 \\
\mathrm{mg} / \mathrm{kg} \text {, ip } 20 \mathrm{~min} \text { before } \\
\text { training }\end{array}$ & $\begin{array}{l}\text { MED: } 0.1 \mathrm{mg} / \mathrm{kg} \text { for both } \\
\text { drugs. Improved object } \\
\text { recognition at } 24 \text { hours }\end{array}$ & $\begin{array}{l}\text { (Bourtchouladze } \\
\text { et al. 2003) }\end{array}$ \\
\hline $\begin{array}{c}\text { Object location } \\
\text { memory (hippocampal } \\
\text { dependent, spatial } \\
\text { memory) }\end{array}$ & $\begin{array}{c}\text { Unimpaired young and } \\
\text { aged-impaired } \\
\text { (rat) }\end{array}$ & $\begin{array}{c}\text { MEM1018 at 0.05, 0.5, } 5 \\
\mathrm{mg} / \mathrm{kg}, \text { ip }\end{array}$ & $\begin{array}{c}\text { MED: } \leq 0.05 \mathrm{mg} / \mathrm{kg} \\
\text { (young) and } 0.5 \mathrm{mg} / \mathrm{kg} \\
\text { (aged) }\end{array}$ & $\begin{array}{c}\text { (Trippodi } \\
\text { and Rose 2003) }\end{array}$ \\
\hline $\begin{array}{c}\text { Delayed responding } \\
\text { (prefrontal cortex } \\
\text { dependent, working } \\
\text { memory) }\end{array}$ & $\begin{array}{l}\text { Unimpaired young and } \\
\text { aged-impaired } \\
\text { (rhesus monkey) }\end{array}$ & $\begin{array}{l}\text { Rolipram } 0.01-100 \\
\text { ug/kg, im } 1 \text { hour before } \\
\text { testing }\end{array}$ & $\begin{array}{c}\text { At } 0.1 \mathrm{ug} / \mathrm{kg} \text {, trend for } \\
\text { improvement in young } \\
\text { Aged subjects impaired } \\
\text { by } 10 \mathrm{ug} / \mathrm{kg} \text {. }\end{array}$ & (Ramos et al. 2003) \\
\hline $\begin{array}{c}\text { Object retrieval } \\
\text { (prefrontal cortex } \\
\text { dependent, executive } \\
\text { functioning, response } \\
\text { inhibition) }\end{array}$ & $\begin{array}{c}\text { Unimpaired } \\
\text { (cynomolgus macaques) }\end{array}$ & $\begin{array}{c}\text { Rolipram } 0.003,0,01 \text { and } \\
0.03 \mathrm{mg} / \mathrm{kg} \text {, im } 30 \mathrm{~min} \\
\text { before testing }\end{array}$ & $\begin{array}{l}\text {-Results are presented in } \\
\text { present thesis- }\end{array}$ & Chapter 7 \\
\hline
\end{tabular}

Abbreviations: ip: intra peritoneal;sc: sub cutane; po: oral; im: intra muscular MED: mediation

\section{PDE5 and cognition}

\section{PDE5 inhibitors}

Prickaerts et al. (1997) for the first time described memory enhancing effects of PDE5 inhibition. In that study zaprinast was used to investigate memory enhancing effects, however zaprinast is not selective for P DE5, i.e. it also inhibits PDE1, 9, 10, and 11. Since then, more highly selective PDE5 inhibitors have been developed, but for the pharmacological treatment of erectile dysfunction. At the moment three PDE5 inhibitors are approved for use in several countries; sildenafil (Viagra), vardenafil (Levitra), and tadalafil (Cialis) (Blokland et al. 2006, in press). One review is available for a detailed discussion on the behavioral effects of PDE5-I (seePrickaerts et al. 2004). The next section will provide some of the more recent findings from the literature and from our own research, as pre- 
sented in this thesis. A complete summary of the available literature at present on PDE5-I and memory is shown in Table 3.

Thus far several studies have shown effects of selective PDE5 inhibitors on memory performance in the object recognition task in rats (Prickaerts et al. 2005; Prickaerts et al. 1997; Prickaerts et al. 2002b). Studies described in the present thesis extend these findings and investigated the effects of PDE5-I in mice (chapters 2 and 4).

Several studies have shown improvement in the elevated plus maze, a behavioral test that measures anxiety and spatial memory in rats and mice. Sildenafil and zaprinast improved performance in this task in rats (Singh and Parle 2003) and mice (Patil et al. 2004b), however another study failed to show an effect of sildenafil in this test and in the open field test (Volke et al. 2003). A possible explanation for this contradiction is that in the previous studies sildenafil was administered immediately after the learning trial and in this study sildenafil was administered 30 min before the first trial. This further supports the role of cGMP in early consolidation instead of acquisition processes (See Prickaerts et al. 2005). Sildenafil treatment also ameliorated the deficits induced by two different models for diabetes and electro convulsive shocks (Patil et al. 2006; Patil et al. 2004b).

Previous studies showed no effects of PDE5-I on spatial tasks, i.e. the water escape task or the Y maze (Prickaerts et al. 2004). However, in hyperammonemia or portacaval shunt deficit models for liver failure, both sildenafil and zaprinast reversed spatial recognition deficits in rats (Erceg et al. 2006; Erceg et al. 2005a; Erceg et al. 2005b).

Previous work showed that zaprinast reversed the deficits induced by the NOS inhibitor 7-nitroindazole in rats in the ORT (Prickaerts et al. 1997). Recent work adds to this in that sildenafil reversed the effects the NOS inhibitor L-NAME, in a complex maze learning paradigm (Devan et al. 2006). Furthermore, various studies investigated the effects of PDE5-I on active and passive avoidance learning in rats, mice and neonatal chicks. Memory impairments caused by scopolamine, a model for diabetes and electro convulsive shocks in rats were reversed by sildenafil treatment (Devan et al. 2004; Patil et al. 2006; Patil et al. 2004b). Although one study failed to show improvement in learning performance after sildenafil treatment in unimpaired and aged rats (Shafiei et al. 2006), others show improvement of learning and memory after treatment with PDE5-I in unimpaired and aged mice and in neonatal chicks (Campbell and Edwards 2006; Patil et al. 2004a). Taken together, a growing amount of evidence shows pro-cognitive effects of PDE5-I in several behavioral memory models. Most research so far has focused on rodent models and it would be of great importance to extend these findings into non-human primates or human clinical studies. Since PDE5-I are clinically accepted for the treatment of male erectile dysfunction, these drugs can be easily tested in a clinical experimental setup.

The effects of sildenafil (100 mg) on early information processing and memory processes in humans have only sporadically been studied. Thus far, no clear effects on the behavioral measures of attention and verbal recognition memory have been reported (Schultheiss et al. 2001). However, there are some methodological considerations since only STM was measured at an already optimal performance allowing a minimal window for treatment effects. 
Yet, in the same study, attention-related event-related brain potential (ERP) measures were enhanced by sildenafil. In addition, another study reported that the simple choice reaction time was faster in sildenafil-treated subjects (Schultheiss et al. 2001). Thus, early information processing in humans can be influenced by PDE5 inhibition, but these processes as well as memory-related processes clearly need more investigation. A recent study by our group, presented in this thesis, investigated the effects of sildenafil on performance in a prefrontal task in non-human primates (chapter 7).

Taken together, animal studies indicate that PDE5 inhibitors have the potential to improve early consolidation processes of LTM, although this may be excluded for spatial information. This memory improvement might be mediated by elevations in central cGMP levels. Sildenafil treatment in humans and primates suggests that information processing may be improved. Table 3 gives an overview of the available literature on the effects of PDE5-I on learning and memory. Recently obtained results by our group are described in the present thesis, but were left out of this table.

Table 3: Effects of PDE5 inhibitors on learning and memory processes

\begin{tabular}{|c|c|c|c|}
\hline $\begin{array}{l}\text { Task } \\
\text { (memory pro- } \\
\text { cess) }\end{array}$ & $\begin{array}{l}\text { Model } \\
\text { (species) }\end{array}$ & Treatment & Reference \\
\hline \multirow[t]{7}{*}{$\begin{array}{c}\text { Object Recognition } \\
\text { task } \\
\text { (hippocampus- } \\
\text { and rhinal cortex- } \\
\text { dependent) }\end{array}$} & Unimpaired (rat) & 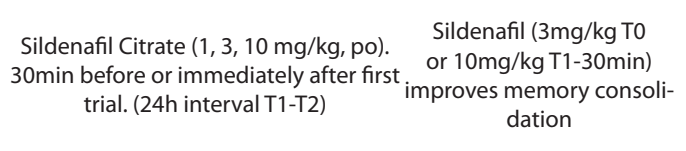 & $\begin{array}{c}\text { (Prickaerts et al. } \\
\text { 2005) }\end{array}$ \\
\hline & Unimpaired (rat) & 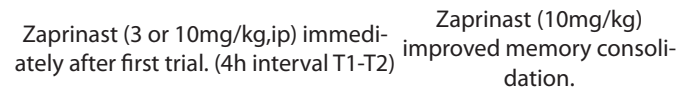 & $\begin{array}{l}\text { (Prickaerts et al. } \\
\text { 1997) }\end{array}$ \\
\hline & Unimpaired (rat) & $\begin{array}{c}\text { Sildenafil }(1,3,10 \mathrm{mg} / \mathrm{kg}, \mathrm{po}) \mathrm{im}- \\
\text { mediately after first trial. }(24 \mathrm{~h} \text { interval } \\
\text { T1-T2) }\end{array}$ & $\begin{array}{l}\text { (Prickaerts et al. } \\
\text { 2002b) }\end{array}$ \\
\hline & Unimpaired (rat) & $\begin{array}{l}\text { Vardenafil }(0.1,0.3,1,3 \mathrm{mg} / \mathrm{kg}, \mathrm{po}) \mathrm{im}-\quad \text { Vardenafil }(0.3 \mathrm{mg} / \mathrm{kg}) \\
\text { mediately after first trial. }(24 \mathrm{~h} \text { interval improved memory consoli- } \\
\text { T1-T2) } \\
\text { dation in ORT. }\end{array}$ & $\begin{array}{l}\text { (Prickaerts et al. } \\
\text { 2002b) }\end{array}$ \\
\hline & Unimpaired (rat) & $\begin{array}{c}\text { Vardenafil ( } 1 \mathrm{mg} / \mathrm{kg}, \mathrm{po}) \text { immediately } \\
\text { after, } 1 \mathrm{~h}, 3 \mathrm{~h} \text { or } 6 \mathrm{~h} \text { after first trial. ( } 24 \mathrm{~h} \\
\text { interval T1-T2) }\end{array}$ & $\begin{array}{l}\text { (Rutten et al. } \\
\text { 2006c) } \\
\text { \& Chapter } 4\end{array}$ \\
\hline & Unimpaired (mouse) & $\begin{array}{c}\text { Sildenafil }(0.3,1,3 \mathrm{mg} / \mathrm{kg}, \mathrm{po}) \mathrm{im}- \\
\text { mediately after first trial. (24h interval } \\
\text { T1-T2) }\end{array}$ & $\begin{array}{l}\text { (Rutten et al. } \\
\text { 2005) } \\
\text { \& Chapter } 2\end{array}$ \\
\hline & $\begin{array}{l}\text { Impaired by NOS } \\
\text { inhibitor (rat) }\end{array}$ & 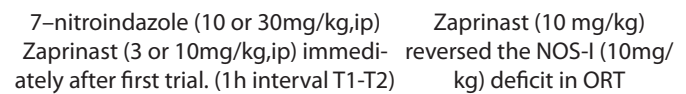 & $\begin{array}{l}\text { (Prickaerts et al. } \\
\text { 1997) }\end{array}$ \\
\hline
\end{tabular}




\begin{tabular}{|c|c|c|c|c|}
\hline $\begin{array}{c}\text { Task } \\
\text { (memory pro- } \\
\text { cess) }\end{array}$ & $\begin{array}{l}\text { Model } \\
\text { (species) }\end{array}$ & Treatment & Results & Reference \\
\hline \multirow[t]{7}{*}{$\begin{array}{l}\text { Elevated Plus-maze: } \\
\text { anxiety and spatial } \\
\text { memory. }\end{array}$} & Unimpaired (rat) & $\begin{array}{l}\text { Sildenafil }(2,4,8 \mathrm{mg} / \mathrm{kg} \text {, ip) } 30 \mathrm{~min} \\
\text { before or immediately after first trial. }\end{array}$ & $\begin{array}{l}\text { Sildenafil }(8 \mathrm{mg} / \mathrm{kg}) \text { before } \\
\text { T1 marginally increased } \\
\text { spatial memory acquisition. } \\
\text { Sildenafil }(2,4,8 \mathrm{mg} / \mathrm{kg}) \\
\text { imm. after } \mathrm{T} 1 \text { increased } \\
\text { spatial memory retention. }\end{array}$ & 2003) \\
\hline & $\begin{array}{l}\text { Unimpaired } \\
\text { (mouse) }\end{array}$ & $\begin{array}{c}\text { Sildenafil }(0.05-10 \mathrm{mg} / \mathrm{kg}, \mathrm{ip}) 30 \mathrm{~min} \\
\text { before test }\end{array}$ & $\begin{array}{l}\text { No effects on plus maze } \\
\text { performance. }\end{array}$ & (Volke et al. 2003) \\
\hline & $\begin{array}{l}\text { Unimpaired } \\
\text { (mouse) } \\
\text { Age impaired } \\
\text { (mouse) }\end{array}$ & $\begin{array}{l}\text { Sildenafil }(0.25,0.5,1 \mathrm{mg} / \mathrm{kg}, \mathrm{ip}) \mathrm{im}- \\
\text { mediately after first trial. }\end{array}$ & $\begin{array}{c}\text { Sildenafil improved spatial } \\
\text { memory performance in } \\
\text { young }(0.5 \text { and } 1.0 \mathrm{mg} / \mathrm{kg}) \\
\text { and aged }(0.25-1 \mathrm{mg} / \mathrm{kg}) \\
\text { animals. }\end{array}$ & (Patil et al. 2004a) \\
\hline & $\begin{array}{l}\text { Unimpaired } \\
\text { (mouse) } \\
\text { Age impaired } \\
\text { (mouse) }\end{array}$ & $\begin{array}{c}\text { Zaprinast }(0.5,1,2 \mathrm{mg} / \mathrm{kg}, \mathrm{ip}) \text { immedi- } \\
\text { ately after first trial }\end{array}$ & $\begin{array}{l}\text { Zaprinast improved spatial } \\
\text { memory performance in } \\
\text { young }(1.0 \text { and } 2.0 \mathrm{mg} / \mathrm{kg}) \\
\text { and aged }(0.5-2 \mathrm{mg} / \mathrm{kg}) \\
\text { animals. }\end{array}$ & (Patil et al. 2004a) \\
\hline & $\begin{array}{l}\text { Impaired by diabetes- } \\
\text { STZ (rat) }\end{array}$ & $\begin{array}{c}\text { Streptozotocin (STZ) }(60 \mathrm{mg} / \mathrm{kg}, \mathrm{ip}) \\
\text { Sildenafil }(0.25,0.5,1 \mathrm{mg} / \mathrm{kg}, \mathrm{ip}) \mathrm{im}- \\
\text { mediately after training. }\end{array}$ & $\begin{array}{l}\text { Sildenafil (all doses) re- } \\
\text { versed STZ spatial memory } \\
\text { deficits. }\end{array}$ & (Patil et al. 2006) \\
\hline & $\begin{array}{l}\text { Impaired by diabetes- } \\
\text { LPS } \\
\text { (mouse) }\end{array}$ & $\begin{array}{c}\text { Lipopolysaccharine (LPS: } 50 \mathrm{ug}, \mathrm{ip}) \text { and } \\
\text { sildenafil }(0.25,0.5,1 \mathrm{mg} / \mathrm{kg}, \mathrm{ip}) \text { or za- } \\
\text { prinast }(0.5,1,2 \mathrm{mg} / \mathrm{kg}, \mathrm{ip}) \mathrm{immediately} \\
\text { after training }\end{array}$ & $\begin{array}{l}\text { d Sildenafil }(0.5 \text { and } 1 \mathrm{mg} / \mathrm{kg} \text { ) } \\
\text { - and Zaprinast ( } 1 \text { and } 2 \mathrm{mg} / \\
\text { y } \mathrm{kg} \text { ) reversed LPS spatial } \\
\text { memory deficits. }\end{array}$ & (Patil et al. 2004b) \\
\hline & $\begin{array}{l}\text { Impaired by Electro } \\
\text { convulsive shock (rat) }\end{array}$ & $\begin{array}{l}\text { Shocks }(0.2 \mathrm{~mA}, 0.2 \mathrm{~s} / \text { day for } 15 \text { days }) \\
\text { Sildenafil }(0.5,1,2 \mathrm{mg} / \mathrm{kg}, \mathrm{ip}) \text { immedi- } \\
\text { ately after training. }\end{array}$ & $\begin{array}{l}\text { Sildenafil (all doses) } \\
\text { reversed spatial memory } \\
\text { deficits }\end{array}$ & (Patil et al. 2006) \\
\hline Open Field & $\begin{array}{l}\text { Unimpaired } \\
\text { (mouse) }\end{array}$ & $\begin{array}{c}\text { Sildenafil }(0.05-10 \mathrm{mg} / \mathrm{kg}, \mathrm{ip}) 30 \mathrm{~min} \\
\text { before test }\end{array}$ & No effects on anxiety & (Volke et al. 2003) \\
\hline \multirow[t]{4}{*}{$\begin{array}{l}\text { Y-maze: spatial rec- } \\
\text { ognition memory } \\
\text { (hippocampus / } \\
\text { cerebellum- depen- } \\
\text { dent) }\end{array}$} & Unimpaired (rat) & $\begin{array}{c}\text { Vardenfil (3mg/kg, po) daily after last } \\
\text { trial. }\end{array}$ & $\begin{array}{l}\text { No effects on spatial } \\
\text { recognition }\end{array}$ & $\begin{array}{l}\text { (Prickaerts et al. } \\
\text { 2004) }\end{array}$ \\
\hline & $\begin{array}{l}\text { Impaired by Hyperam- } \\
\text { monemia } \\
\text { (rat) }\end{array}$ & $\begin{array}{l}\text { Sildenafil }(50 \mathrm{mg} / \mathrm{L}) \text { in drinking water } \\
\text { two days before training. }\end{array}$ & $\begin{array}{l}\text { Sildenafil (in drink water) } \\
\text { reversed spatial recogni- } \\
\text { tion deficits. }\end{array}$ & (Erceg et al. 2006) \\
\hline & $\begin{array}{l}\text { Impaired by Hyperam- } \\
\text { monemia } \\
\text { (rat) }\end{array}$ & $\begin{array}{l}\text { Ammonium acetate containing diet } \\
\text { ( } 28 \text { days before testing) } \\
\text { Zaprinast ( } 50 \mathrm{uM}, 0.25 \mathrm{ul} / \mathrm{h}, 2 \text { days } \\
\text { before testing) in cerebral ventricle. }\end{array}$ & $\begin{array}{l}\text { Zaprinast (through mini- } \\
\text { pump) reversed spatial } \\
\text { recognition deficits. }\end{array}$ & $\begin{array}{l}\text { (Erceg et al. } \\
\text { 2005a) }\end{array}$ \\
\hline & $\begin{array}{l}\text { Impaired by Portacaval } \\
\text { Shunts } \\
\text { (rat) }\end{array}$ & $\begin{array}{l}\text { Portacaval shunt operation } 28 \text { days } \\
\text { before test. } \\
\text { Sildenafil }(50 \mathrm{mg} / \mathrm{L}) \text { in drinking water } \\
\text { two days before training. }\end{array}$ & $\begin{array}{l}\text { Sildenafil (in drink water) } \\
\text { reversed spatial recogni- } \\
\text { tion deficits. }\end{array}$ & $\begin{array}{l}\text { (Erceg et al. } \\
\text { 2005b) }\end{array}$ \\
\hline $\begin{array}{l}\text { Water Escape Task: } \\
\text { spatial memory } \\
\text { (hippocampus) }\end{array}$ & Unimpaired (rat) & $\begin{array}{c}\text { Zaprinast }(10 \mathrm{mg} / \mathrm{kg}, \mathrm{ip}) \text { daily after } \\
\text { last trial. }\end{array}$ & $\begin{array}{l}\text { No effects on acquisition } \\
\text { or retention of spatial } \\
\text { memory }\end{array}$ & $\begin{array}{l}\text { (Prickaerts et al. } \\
\text { 2004) }\end{array}$ \\
\hline
\end{tabular}




\begin{tabular}{|c|c|c|c|c|}
\hline $\begin{array}{l}\text { Task } \\
\text { (memory pro- } \\
\text { cess) }\end{array}$ & $\begin{array}{l}\text { Model } \\
\text { (species) }\end{array}$ & Treatment & Results & Reference \\
\hline $\begin{array}{l}\text { Complex Maze } \\
\text { Learning (hippo- } \\
\text { campus) }\end{array}$ & $\begin{array}{l}\text { Impaired by NOS } \\
\text { inhibitor (rat) }\end{array}$ & $\begin{array}{l}\text { L-NAME (60mg/kg,ip) } 30 \mathrm{~min} \text { before } \\
\text { training } \\
\text { Sildenafil }(1,1.5,3 \text {, or } 4.5 \mathrm{mg} / \mathrm{kg} \text {, ip) } \\
15 \mathrm{~min} \text { before training. }\end{array}$ & $\begin{array}{l}\text { Sildenafil }(1.5 \mathrm{mg} / \mathrm{kg}) \\
\text { attenuated the L-NAME } \\
\text { deficit in Maze learning. }\end{array}$ & $\begin{array}{l}\text { (Devan et al. } \\
\text { 2006) }\end{array}$ \\
\hline \multirow[t]{2}{*}{$\begin{array}{l}\text { Active Avoidance } \\
\text { learning (hippo- } \\
\text { campus) }\end{array}$} & $\begin{array}{l}\text { Impaired by Scopol- } \\
\text { amine (rat) }\end{array}$ & $\begin{array}{l}\text { Scop. (0.75mg/kg, i.p) } 30 \mathrm{~min} \text { before } \\
\text { training } \\
\text { Sildenafil }(1.5,3 \text { or } 4.5 \mathrm{mg} / \mathrm{kg}, \mathrm{ip}) 15 \mathrm{~min} \\
\text { before training. }\end{array}$ & $\begin{array}{l}\text { Sildenafil }(3 \mathrm{mg} / \mathrm{kg}) \\
\text { reversed the scopolamine } \\
\text { deficit in active avoidance } \\
\text { task. }\end{array}$ & $\begin{array}{l}\text { (Devan et al. } \\
\text { 2004) }\end{array}$ \\
\hline & $\begin{array}{l}\text { Unimpaired } \\
\text { (mouse) }\end{array}$ & $\begin{array}{c}\text { Sildenafil ( } 1,3,10 \text { or } 30 \text { mg/kg, i.p.) } 30 \\
\text { min before training or immediately } \\
\text { after training }\end{array}$ & $\begin{array}{l}\text { Sildenafil }(3 \mathrm{mg} / \mathrm{kg}) \mathrm{im} \text { - } \\
\text { proved performance (both } \\
\text { 30min before and imm. } \\
\text { after training) in active } \\
\text { avoidance. }\end{array}$ & $\begin{array}{l}\text { (Baratti and Boc- } \\
\text { cia 1999) }\end{array}$ \\
\hline \multirow[t]{7}{*}{$\begin{array}{l}\text { Passive Avoidance } \\
\text { (hippocampus) }\end{array}$} & Unimpaired (rat) & $\begin{array}{c}\text { Sildenafil }(1,3,10,20 \mathrm{mg} / \mathrm{kg}, \mathrm{ip}) \mathrm{im}- \\
\text { mediately after training in young and } \\
\text { old rats. }\end{array}$ & $\begin{array}{l}\text { Sildenafil has no effect on } \\
\text { retention performance in } \\
\text { passive avoidance. }\end{array}$ & $\begin{array}{l}\text { (Shafiei et al. } \\
\text { 2006) }\end{array}$ \\
\hline & $\begin{array}{l}\text { Unimpaired } \\
\text { (neonate chick) }\end{array}$ & $\begin{array}{l}\text { Zaprinast (0.1-750uM/side, ic) im- } \\
\text { mediately after training. }\end{array}$ & $\begin{array}{c}\text { Zaprinast (>100uM) en- } \\
\text { hanced early consolidation. }\end{array}$ & $\begin{array}{l}\text { (Campbell and } \\
\text { Edwards 2006) }\end{array}$ \\
\hline & $\begin{array}{l}\text { Unimpaired } \\
\text { (mouse) } \\
\text { Age impaired } \\
\text { (mouse) }\end{array}$ & $\begin{array}{c}\text { Sildenafil }(0.25,0.5,1 \mathrm{mg} / \mathrm{kg} \text {, ip) im- } \\
\text { mediately after first trial. }\end{array}$ & $\begin{array}{l}\text { Sildenafil improved } \\
\text { consolidation in young }(0.5 \\
\text { and } 1.0 \mathrm{mg} / \mathrm{kg}) \text { and aged } \\
(0.25-1 \mathrm{mg} / \mathrm{kg}) \text { animals. }\end{array}$ & (Patil et al. 2004a) \\
\hline & $\begin{array}{l}\text { Unimpaired } \\
\text { (mouse) } \\
\text { Age impaired } \\
\text { (mouse) }\end{array}$ & $\begin{array}{c}\text { Zaprinast }(0.5,1,2 \mathrm{mg} / \mathrm{kg}, \mathrm{ip}) \text { immedi- } \\
\text { ately after first trial }\end{array}$ & $\begin{array}{l}\text { Zaprinast improved spatial } \\
\text { memory performance in } \\
\text { young }(1.0 \text { and } 2.0 \mathrm{mg} / \mathrm{kg}) \\
\text { and aged }(0.5-2 \mathrm{mg} / \mathrm{kg}) \\
\text { animals. }\end{array}$ & (Patil et al. 2004a) \\
\hline & $\begin{array}{l}\text { Impaired by Diabetes } \\
\text { (rat) }\end{array}$ & $\begin{array}{c}\mathrm{STZ}(60 \mathrm{mg} / \mathrm{kg}, \mathrm{ip}) \\
\text { Sildenafil }(0.25,0.5,1 \mathrm{mg} / \mathrm{kg} \text {, ip) im- } \\
\text { mediately after training. }\end{array}$ & $\begin{array}{l}\text { Sildenafil (all doses) re- } \\
\text { versed STZ memory deficit } \\
\text { of diabetes. }\end{array}$ & (Patil et al. 2006) \\
\hline & $\begin{array}{l}\text { Impaired by Electro } \\
\text { convulsive shock (rat) }\end{array}$ & $\begin{array}{l}\text { Shocks }(0.2 \mathrm{~mA}, 0.2 \mathrm{~s} / \text { day for } 15 \text { days }) \\
\text { Sildenafil }(0.5,1,2 \mathrm{mg} / \mathrm{kg} \text {, ip) immedi- } \\
\text { ately after training. }\end{array}$ & $\begin{array}{l}\text { Sildenafil (all doses) } \\
\text { - reversed memory deficit of } \\
\text { diabetes. }\end{array}$ & (Patil et al. 2006) \\
\hline & $\begin{array}{l}\text { Impaired by diabetes- } \\
\text { LPS } \\
\text { (mouse) }\end{array}$ & \multicolumn{3}{|c|}{ 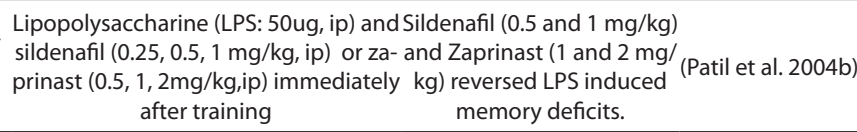 } \\
\hline $\begin{array}{l}\text { Object retrieval/ } \\
\text { detour task (pre- } \\
\text { frontal) }\end{array}$ & $\begin{array}{c}\text { Unimpaired } \\
\text { (cynomolgus macaque) }\end{array}$ & $\begin{array}{c}\text { Sildenafil }(0.3,1,3 \mathrm{mg} / \mathrm{kg} \text {, im }) 30 \mathrm{~min} \\
\text { before test. }\end{array}$ & $\begin{array}{l}\text {-Results are presented in } \\
\text { present thesis- }\end{array}$ & Chapter 7 \\
\hline $\begin{array}{l}\text { Verbal recognition } \\
\text { memory \& ERP }\end{array}$ & Unimpaired (human) & $\begin{array}{c}\text { Sildenafil (100mg) capsule } 1 \mathrm{~h} \text { before } \\
\text { test. }\end{array}$ & $\begin{array}{l}\text { ERP:Reduction of of nega- } \\
\text { tivity in } 150-250 \mathrm{~ms} \text { range. }\end{array}$ & $\begin{array}{l}\text { (Schultheiss et al. } \\
\text { 2001) }\end{array}$ \\
\hline $\begin{array}{c}\text { Auditory selective } \\
\text { attention }\end{array}$ & Unimpaired (human) & $\begin{array}{l}\text { Sildenafil (100mg) capsule } 1 \mathrm{~h} \text { before } \\
\text { test. }\end{array}$ & $\begin{array}{l}\text { ERP: indicative of enhanced } \\
\text { ability to focus attention }\end{array}$ & $\begin{array}{l}\text { (Schultheiss et al. } \\
\text { 2001) }\end{array}$ \\
\hline $\begin{array}{l}\text { Simple Choice reac- } \\
\text { tion test. }\end{array}$ & Unimpaired (human) & $\begin{array}{c}\text { Sildenfil (100mg) capsule } 1 \mathrm{~h} \text { before } \\
\text { test. }\end{array}$ & $\begin{array}{l}\text { Sildenafil enhanced simple } \\
\text { reaction times. }\end{array}$ & (Grass et al. 2001) \\
\hline
\end{tabular}

Abbreviations: ip: intra peritoneal;sc: sub cutane; po: oral; im: intra muscular; ERP: evoked response potential 


\section{Aim and outline of the Thesis}

Taken together the studies described above strongly indicate that PDE-Is can enhance the effects of cAMP and/or cGMP and may therefore improve learning and memory. The main question in this thesis was whether PDE-I enhances specific memory modalities and processes in different animal models.

As mentioned before the PDE5-I enhances memory in rats and mice. We investigated sildenafil in the object recognition task in Swiss mice and looked at the cGMP immunoreactivity (IR) in the hippocampus. Since the pre-synaptic mechanism of NO-cGMP is suggested in the early phase of LTP (see above) we tried to show a pre-synaptic co-localization of cGMP and a pre-synaptic marker (i.e. synaptophysin) (Chapter 2).

The effect of rolipram and the temporal effects on object memory were investigated in rats. Bernabeu et al. (1996) showed that intra-hippocampal injections of 8Br-cAMP were only effective 3 h after learning. We hypothesized that the PDE4 inhibitor rolipram, that enhances cAMP levels, should therefore also be effective around $3 \mathrm{~h}$ after learning. We investigated the administration time-dependent effects of rolipram on memory performance in the object recognition task. Furthermore we wanted to test the effects if rolipram in the scopolamine deficit model. (Chapter3).

To further examine the administration time related effects of PDE-Is and the time-dependent effects of cAMP and cGMP on object memory we examined the effects of three different PDE-Is, namely PDE-4, -5 , and -2 inhibitors in rats. Compounds were administered at different time points after training. (Chapter 4)

To test the notion that PDE4-I can also enhance memory by interaction with different neurotransmitter systems, for instance rolipram attenuated the scopolamine-induced memory deficit, we hypothesized that rolipram may also reverse the deficit caused by a different model for amnesia, namely acute trypthophan depletion. (Chapter 5)

To study the function of PDE4 in animal models, PDE4 knock-out (KO) mice have been generated (Jin et al. 2005). These $\mathrm{KO}$ mice have been generated for two different isoforms of PDE4, namely PDE4D and PDE4B that are widely distributed in the mouse, rat, monkey and human brain (Dlaboga et al. 2006; Perez-Torres et al. 2000). Based on the literature, it was hypothesized that PDE4D-KO animals have a pro-cognitive-antidepressive profile (Zhang et al. 2002). To see whether this hypothesis holds, we tested PDE4B and PDE4D KO mice in a fear conditioning paradigm. Animals were tested for LTM, STM and control experiments for locomotion and nociception (i.e pain perception) were conducted (Chapter 6). 
To further extend the knowledge on the cognitive enhancing effects of PDE4-I and PDE5-I we decided to investigate the effects of these compounds in Cynomolgus macaques. The model of object retrieval focuses on prefrontal mediated responses. We hypothesized that PDE -I may also produce enhancing effects in other brain regions, such as the prefrontal cortex (Chapter 7).

\section{References}

Austen J (1961) Mansfield Park. Mr. Egerton, Mr. Egerton

Bach ME, Barad M, Son H, Zhuo M, Lu YF, Shih R, Mansuy I, Hawkins RD, Kandel ER (1999) Age-related defects in spatial memory are correlated with defects in the late phase of hippocampal long-term potentiation in vitro and are attenuated by drugs that enhance the cAMP signaling pathway. Proc. Natl. Acad. Sci. USA 96: 5280-5

Baddeley A (2003) Working memory: looking back and looking forward. Nat. Rev. Neurosci. 4: 829-839

Bailey CH, Bartsch D, Kandel ER (1996) Toward a molecular definition of long-term memory storage. Proc. Natl. Acad. Sci. USA 93: 13445-52

Barad M, Bourtchouladze R, Winder DG, Golan H, Kandel E (1998) Rolipram, a type IV-specific phosphodiesterase inhibitor, facilitates the establishment of long-lasting long-term potentiation and improves memory. Proc. Natl. Acad. Sci. USA 95: 15020-15025

Baratti CM, Boccia MM (1999) Effects of sildenafil on long-term retention of an inhibitory avoidance response in mice. Behav. Pharmacol. 10: 731-737

Barco A, Pittenger C, Kandel ER (2003) CREB, memory enhancement and the treatment of memory disorders: promises, pitfalls and prospects. Expert. Opin. Ther. Targets. 7: 101-14

Bartus RT, Dean RL, Pontecorvo MJ, Flicker C (1985) The cholinergic hypothesis: a historical overview, current perspective, and future directions. Ann. N. Y. Acad. Sci. 444: 332-358

Bernabeu R, Bevilaqua L, Ardenghi P, Bromberg E, Schmitz P, Bianchin M, Izquierdo I, Medina JH (1997) Involvement of hippocampal cAMP/cAMP-dependent protein kinase signaling pathways in a late memory consolidation phase of aversively motivated learning in rats. Proc. Natl. Acad. Sci. USA 94: 7041-6

Bernabeu R, Schmitz P, Faillace MP, Izquierdo I, Medina JH (1996) Hippocampal cGMP and cAMP are differentially involved in memory processing of inhibitory avoidance learning. Neuroreport 7: 585-588

Blaney PH (1986) Affect and memory: a review. Psychol. Bull. 99: 229-246

Bliss TV, Collingridge GL (1993) A synaptic model of memory: long-term potentiation in the hippocampus. Nature 361: 31-9

Blokland A, Schreiber R, Prickaerts J (2006, in press) Improving Memory: A role for Phosphodiesterases. Curr. Pharm. Des.

Boess FG, Hendrix M, van der Staay FJ, Erb C, Schreiber R, van Staveren W, de Vente J, Prickaerts J, Blokland A, Koenig G (2004) Inhibition of phosphodiesterase 2 increases neuronal cGMP, synaptic plasticity and memory performance. Neuropharmacology 47: 1081-92

Bourtchouladze R, Lidge R, Catapano R, Stanley J, Gossweiler S, Romashko D, Scott R, Tully T (2003) A mouse model of Rubinstein-Taybi syndrome: defective long-term memory is ameliorated by inhibitors of phosphodiesterase 4. Proc. Natl. Acad. Sci. U S A 100: 10518-22

Cahill L, Prins B, Weber M, McGaugh JL (1994) Beta-adrenergic activation and memory for emotional events. Nature 371: 702-704

Campbell E, Edwards T (2006) Zaprinast consolidates long-term memory when administered to neonate chicks trained using a weakly reinforced single trial passive avoidance task. Behav. Brain. Res. 169: 181-5

Chien WL, Liang KC, Teng CM, Kuo SC, Lee FY, Fu WM (2003) Enhancement of long-term potentiation by a potent nitric oxide-guanylyl cyclase activator, 3-(5-hydroxymethyl-2-furyl)-1-benzyl-indazole. Mol. Pharmacol. 63: 1322-8

Comery TA, Martone RL, Aschmies S, Atchison KP, Diamantidis G, Gong X, Zhou H, Kreft AF, Pangalos MN, Sonnenberg-Reines J, Jacobsen JS, Marquis KL (2005) Acute gamma-secretase inhibition improves contextual fear conditioning in the Tg2576 mouse model of Alzheimer's disease. 25: 8898-902 
Davis HP, Squire LR (1984) Protein synthesis and memory: a review. Psychol. Bull. 96: 518-59

Devan BD, Bowker JL, Duffy KB, Bharati IS, Jimenez M, Sierra-Mercado D, Jr., Nelson CM, Spangler EL, Ingram DK (2006) Phosphodiesterase inhibition by sildenafil citrate attenuates a maze learning impairment in rats induced by nitric oxide synthase inhibition. Psychopharmacology (Berl) 183: 439-45

Devan BD, Sierra-Mercado D, Jr., Jimenez M, Bowker JL, Duffy KB, Spangler EL, Ingram DK (2004) Phosphodiesterase inhibition by sildenafil citrate attenuates the learning impairment induced by blockade of cholinergic muscarinic receptors in rats. Pharmacol. Biochem. Behav. 79: 691-9

DeZazzo J, Tully T (1995) Dissection of memory formation: from behavioral pharmacology to molecular genetics. Trends. Neurosci. 18: 212-218

Dlaboga D, Hajjhussein H, O’Donnell JM (2006) Regulation of phosphodiesterase-4 (PDE4) expression in mouse brain by repeated antidepressant treatment: comparison with rolipram. Brain Res. 1096: 104-112

Ebert U, Kirch W (1998) Scopolamine model of dementia: electroencephalogram findings and cognitive performance. Eur. J. Clin. Invest. 28: 944-949

Egawa T, Mishima K, Matsumoto Y, Iwasaki K, Fujiwara M (1997) Rolipram and its optical isomers, phosphodiesterase 4 inhibitors, attenuated the scopolamine-induced impairments of learning and memory in rats. Jpn. J. Pharmacol. 75: 275-281

Ennaceur A, Delacour J (1988) A new one-trial test for neurobiological studies of memory in rats. 1: Behavioral data. Behav. Brain Res. 31: 47-59

Erceg S, Monfort P, Cauli O, Montoliu C, Llansola M, Piedrafita B, Felipo V (2006) Role of extracellular cGMP and of hyperammonemia in the impairment of learning in rats with chronic hepatic failure. Therapeutic implications. Neurochem. Int. 48: 441-6

Erceg S, Monfort P, Hernandez-Viadel M, Llansola M, Montoliu C, Felipo V (2005a) Restoration of learning ability in hyperammonemic rats by increasing extracellular cGMP in brain. Brain. Res. 1036: 115-121

Erceg S, Monfort P, Hernandez-Viadel M, Rodrigo R, Montoliu C, Felipo V (2005b) Oral administration of sildenafil restores learning ability in rats with hyperammonemia and with portacaval shunts. Hepatology 41: 299-306

Frey U, Huang YY, Kandel ER (1993) Effects of cAMP simulate a late stage of LTP in hippocampal CA1 neurons. Science 260: 1661-4

Frith C (1996) Neuropsychology of schizophrenia, what are the implications of intellectual and experiential abnormalities for the neurobiology of schizophrenia? Br. Med. Bull. 52: 618-626

Ghelardini C, Galeotti N, Gualtieri F, Romanelli MN, Bucherelli C, Baldi E, Bartolini A (2002) DM235 (sunifiram): a novel nootropic with potential as a cognitive enhancer. Naunyn Schmiedebergs Arch. Pharmacol. 365:419-26

Gong B, Vitolo OV, Trinchese F, Liu S, Shelanski M, Arancio O (2004) Persistent improvement in synaptic and cognitive functions in an Alzheimer mouse model after rolipram treatment. J. Clin. Invest. 114: 1624-1634

Grass H, Klotz T, Fathian-Sabet B, Berghaus G, Engelmann U, Kaferstein H (2001) Sildenafil (Viagra): is there an influence on psychological performance? Int. Urol. Nephrol. 32: 409-412

Imanishi T, Sawa A, Ichimaru Y, Miyashiro M, Kato S, Yamamoto T, Ueki S (1997) Ameliorating effects of rolipram on experimentally induced impairments of learning and memory in rodents. Eur. J. Pharmacol. 321: 273-278

Impey S, Mark M, Villacres EC, Poser S, Chavkin C, Storm DR (1996) Induction of CRE-mediated gene expression by stimuli that generate long-lasting LTP in area CA1 of the hippocampus. Neuron 16: 973-82

Izquierdo I, Barros DM, Mello e Souza T, de Souza MM, Izquierdo LA, Medina JH (1998) Mechanisms for memory types differ. Nature 393: 635-636

Jin SL, Latour AM, Conti M (2005) Generation of PDE4 knockout mice by gene targeting. Methods Mol. Biol. 307: 191-210

Krause W, Kuhne G (1988) Pharmacokinetics of rolipram in the rhesus and cynomolgus monkeys, the rat and the rabbit. Studies on species differences. Xenobiotica 18: 561-71

LeDoux JE (2000) Emotion circuits in the brain. Annu. Rev. Neurosci. 23: 155-84

Lezak MD (1995) Neuropsychological Assesment, 3rd ed edn. Oxford University Press, Oxford University Press

Lieben CK, Blokland A, Sik A, Sung E, van Nieuwenhuizen P, Schreiber R (2005) The selective 5-HT6 receptor antagonist Ro4368554 restores memory performance in cholinergic and serotonergic models of memory deficiency in the rat. Neuropsychopharmacology 30: 2169-2179 
Lieben CK, van Oorsouw K, Deutz NE, Blokland A (2004) Acute tryptophan depletion induced by a gelatin-based mixture impairs object memory but not affective behavior and spatial learning in the rat. Behav. Brain. Res. 151: 53-64

Lu YF, Hawkins RD (2002) Ryanodine receptors contribute to cGMP-induced late-phase LTP and CREB phosphorylation in the hippocampus. J. Neurophysiol. 88: 1270-8

Lu YF, Kandel ER, Hawkins RD (1999) Nitric oxide signaling contributes to late-phase LTP and CREB phosphorylation in the hippocampus. J. Neurosci. 19: 10250-61

Mattson MP, Chan SL, Duan W (2002) Modification of brain aging and neurodegenerative disorders by genes, diet, and behavior. Physiol. Rev. 82: 637-672

McGaugh JL (1989) Dissociating learning and performance: drug and hormone enhancement of memory storage. Brain. Res. Bull. 23: 339-345

Messier C (2004) Glucose improvement of memory: a review. Eur. J. Pharmacol. 490: 33-57

Monti B, Berteotti C, Contestabile A (2006) Subchronic Rolipram Delivery Activates Hippocampal CREB and Arc, Enhances Retention and Slows Down Extinction of Conditioned Fear. Neuropsychopharmacology 31: 278-86

Morris RGM (1984) Developments of a water-maze procedure for studying spatial learning in the rat. J. Neurosci. Meth. 11: 47-60

Nagakura A, Niimura M, Takeo S (2002) Effects of a phosphodiesterase IV inhibitor rolipram on microsphere embolism-induced defects in memory function and cerebral cyclic AMP signal transduction system in rats. Br. J. Pharmacol. 135: 1783-93

Ng KT, Gibbs ME, Crowe SF, Sedman GL, Hua F, Zhao W, O’Dowd B, Rickard N, Gibbs CL, Sykova E, et al. (1991) Molecular mechanisms of memory formation. Mol. Neurobiol. 5: 333-350

Pang PT, Lu B (2004) Regulation of late-phase LTP and long-term memory in normal and aging hippocampus: role of secreted proteins tPA and BDNF. Ageing Res. Rev. 3: 407-430

Park SB, Coull JT, McShane RH, Young AH, Sahakian BJ, Robbins TW, Cowen PJ (1994) Tryptophan depletion in normal volunteers produces selective impairments in learning and memory. Neuropharmacology 33: 575-588

Patil CS, Jain NK, Singh VP, Kulkarni SK (2004a) Differential Effect of the PDE5 Inhibitors, Sildenafil and Zaprinast, in Aging- and Lippolysaccharide-Induced Cognitive Dysfunction in Mice. Drug. Dev. Res. 63: 66-75

Patil CS, Singh VP, Kulkarni SK (2006) Modulatory effect of sildenafil in diabetes and electroconvulsive shock-induced cognitive dysfunction in rats. Pharmacol. Rep. 58: 373-380

Patil CS, Singh VP, Singh S, Kulkarni SK (2004b) Modulatory Effect of the PDE-5 Inhibitor Sildenafil in Diabetic Neuropathy. Pharmacology 72: 192-195

Perez-Torres S, Miro X, Palacios JM, Cortes R, Puigdomenech P, Mengod G (2000) Phosphodiesterase type 4 isozymes expression in human brain examined by in situ hybridization histochemistry and[3H]rolipram binding autoradiography. Comparison with monkey and rat brain. J. Chem. Neuroanat. 20: 349-74

Prickaerts J, de Vente J, Honig W, Steinbusch HW, Blokland A (2002a) cGMP, but not cAMP, in rat hippocampus is involved in early stages of object memory consolidation. Eur. J. Pharmacol. 436: 83-87

Prickaerts J, Sik A, van der Staay FJ, de Vente J, Blokland A (2005) Dissociable effects of acetylcholinesterase inhibitors and phosphodiesterase type 5 inhibitors on object recognition memory: acquisition versus consolidation. Psychopharmacology (Berl) 177: 381-390

Prickaerts J, Sik A, van Staveren WC, Koopmans G, Steinbusch HW, van der Staay FJ, de Vente J, Blokland A (2004) Phosphodiesterase type 5 inhibition improves early memory consolidation of object information. Neurochem. Int. 45: 915-928

Prickaerts J, Steinbusch HW, Smits JF, de Vente J (1997) Possible role of nitric oxide-cyclic GMP pathway in object recognition memory: effects of 7-nitroindazole and zaprinast. Eur. J. Pharmacol. 337: 125-136

Prickaerts J, van Staveren WC, Sik A, Markerink-van Ittersum M, Niewohner U, van der Staay FJ, Blokland A, de Vente $\mathrm{J}$ (2002b) Effects of two selective phosphodiesterase type 5 inhibitors, sildenafil and vardenafil, on object recognition memory and hippocampal cyclic GMP levels in the rat. Neuroscience 113: 351-361

Ramos BP, Birnbaum SG, Lindenmayer I, Newton SS, Duman RS, Arnsten AF (2003) Dysregulation of protein kinase a signaling in the aged prefrontal cortex: new strategy for treating age-related cognitive decline. Neuron 40: 835-45

Randt CT, Judge ME, Bonnet KA, Quartermain D (1982) Brain cyclic AMP and memory in mice. Pharmacol. Biochem. Behav. 17: 677-80 
Riedel WJ, Klaassen T, Deutz NE, van Someren A, van Praag HM (1999) Tryptophan depletion in normal volunteers produces selective impairment in memory consolidation. Psychopharmacology (Berl) 141: 362-369

Rutten K, Lieben C, Smits L, Blokland A (in press) The PDE4 inhibitor rolipram reverses the object memory impairment induced by acute tryptophan depletion. Neuropharmacology

Rutten K, Prickaerts J, Blokland A (2006a) Rolipram reverses scopolamine-induced and time-dependent memory deficits in object recognition by different mechanisms of action. Neurobiol. Learn. Mem. 85: 132-8

Rutten K, Prickaerts J, Hendrix M, van der Staay FJ, Sik A, Blokland A (2006b) Time-dependent involvement of cAMP and cGMP in consolidation of object memory: Studies using selective phosphodiesterase type 2, 4 and 5 inhibitors. Eur. J. Pharmacol.

RuttenK,VenteJD,SikA,IttersumMM,PrickaertsJ,BloklandA(2005)TheselectivePDE5inhibitor, sildenafil,improves objectmemoryinSwissmiceandincreasescGMPlevelsinhippocampalslices. Behav.Brain. Res.164:11-6

Sambeth A, Blokland A, Harmer C, Klilkens T, Nathan P, Porter R, Schmitt J, Scholtissen B, Sobczak S, Young A, Riedel W (in press) Sex differences in the effect of acute tryptophan depletion on declarative episodic memory: A pooled analysis of nine studies. Neurosci. Biobehav. Rev.

Schacter DL (1987) Implicit memory: history and current status. Journal of experimental psychology: Learning, memory and cognition 13: 501-518

Schmitt JA, Jorissen BL, Sobczak S, van Boxtel MP, Hogervorst E, Deutz NE, Riedel WJ (2000) Tryptophan depletion impairs memory consolidation but improves focussed attention in healthy young volunteers. J. Psychopharmacol. 14: 21-29

Schultheiss D, Muller SV, Nager W, Stief CG, Schlote N, Jonas U, Asvestis C, Johannes S, Munte TF (2001) Central effects of sildenafil (Viagra) on auditory selective attention and verbal recognition memory in humans: a study with event-related brain potentials. World J. Urol. 19: 46-50

Shafiei M, Mahmoudian M, Rostami P, Nemati F (2006) Effect of sildenafil (Viagra) on memory retention of a passive avoidance response in rats. Acta Physiol. Hung. 93: 53-59

Singh N, Parle M (2003) Sildenafil improves acquisition and retention of memory in mice. Indian J. Physiol. Pharmacol. 47: 318-324

Son H, Lu YF, Zhuo M, Arancio O, Kandel ER, Hawkins RD (1998) The specific role of cGMP in hippocampal LTP. Learn. Mem. 5: 231-45

Squire LR, Knowlton B, Musen G (1993) The structure and organization of memory. Annu. Rev. Psychol. 44: 453-495

Trippodi C, Rose GM (2002) evaluation of MEM 1414 in novel object recognition memory. Soc. Neurosci. Abst. 80.4

Trippodi C, Rose GM (2003) Object Recognition and Object Location Memory in Young and Aged Sprague Dawley Rats. Soc. Neurosci. Abst. 625.9

Tully T, Bourtchouladze R, Scott R, Tallman J (2003) Targeting the CREB pathway for memory enhancers. Nat. Rev. Drug. Discov. 2: 267-277

van Staveren WC, Markerink-van Ittersum M, Steinbusch HW, de Vente J (2001) The effects of phosphodiesterase inhibition on cyclic GMP and cyclic AMP accumulation in the hippocampus of the rat. Brain. Res. 888: 275-286

Volke V, Wegener G, Vasar E (2003) Augmentation of the NO-cGMP cascade induces anxiogenic-like effect in mice. J. Physiol. Pharmacol. 54: 653-660

Voronin L, Byzov A, Kleschevnikov A, Kozhemyakin M, Kuhnt U, Volgushev M (1995) Neurophysiological analysis of long-term potentiation in mammalian brain. Behav. Brain Res. 66: 45-52

Zhang HT, Crissman AM, Dorairaj NR, Chandler LJ, O’Donnell JM (2000) Inhibition of cyclic AMP phosphodiesterase (PDE4) reverses memory deficits associated with NMDA receptor antagonism. Neuropsychopharmacology 23: 198-204

Zhang HT, Huang Y, Jin SL, Frith SA, Suvarna N, Conti M, O’Donnell JM (2002) Antidepressant-like profile and reduced sensitivity to rolipram in mice deficient in the PDE4D phosphodiesterase enzyme. Neuropsychopharmacology 27: 587-95

Zhang HT, Huang Y, Suvarna NU, Deng C, Crissman AM, Hopper AT, De Vivo M, Rose GM, O’Donnell J M (2005) Effects of the novel PDE4 inhibitors MEM1018 and MEM1091 on memory in the radial-arm maze and inhibitory avoidance tests in rats. Psychopharmacology (Berl)

Zhang HT, O’Donnell JM (2000) Effects of rolipram on scopolamine-induced impairment of working and reference memory in the radial-arm maze tests in rats. Psychopharmacology (Berl) 150: 311-316 
Zhang HT, Zhao Y, Huang Y, Dorairaj NR, Chandler LJ, O’Donnell JM (2004) Inhibition of the phosphodiesterase 4 (PDE4) enzyme reverses memory deficits produced by infusion of the MEK inhibitor U0126 into the CA1 subregion of the rat hippocampus. Neuropsychopharmacology 29: 1432-9

Zola-Morgan S, Squire LR (1993) Neuroanatomy of memory. Annu. Rev. Neurosci. 16: 547-563 


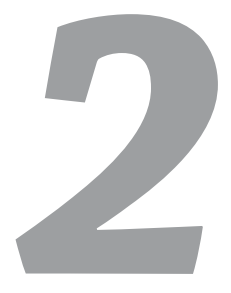

\title{
The SElective PDE5 INHIBITOR
} SILDENAFIL IMPROVES OBJECT MEMORY IN SWISS MICE AND INCREASE CGMP LEVELS IN HIPPOCAMPAL SLICES

\author{
K. Rutten, J. De Vente, A. Şik, M. Markerink-van Ittersum, \\ J. Prickaerts And A. Blokland
}

Behavioral Brain Research (2005) 164: 1-16

Previous studies have shown memory enhancing effects of phosphodiesterase type 5 (PDE5) inhibitors in rats. However, differences in nitric oxide (NO)-mediated cyclic GMP (cGMP) signaling in the hippocampus have been described between rats and mice. In the present study we investigated the memory enhancing effects of the PDE5 inhibitor, sildenafil on memory performance in Swiss mice using the object recognition task. Sildenafil (0.3, 1 and $3 \mathrm{mg} / \mathrm{kg})$ was administered orally directly after the first trial. The memory for the objects was retested 24-h later when mice show no memory for the familiar object. Sildenafil improved the object discrimination performance of Swiss mice at a dose of $1 \mathrm{mg} / \mathrm{kg}$. Hippocampal slices of Swiss mice incubated with sildenafil $(10 \mu \mathrm{M})$ increased cGMP levels in varicosities in the $C A 3$ region of the hippocampus and a number of short, thin fibers. Addition of DEA/NO, an NO donor $(10 \mu \mathrm{M})$, in the presence of sildenafil $(10 \mu \mathrm{M})$ strongly increased cGMP immunoreactivity of varicosities in the CA3 region. Double immunostaining of cGMP with the presynaptic marker synaptophysin did not reveal any co-localization of these markers under any circumstance. Taken together, inhibition of PDE5 improves object recognition memory in mice. Furthermore, a postsynaptic role of cGMP could be involved in this respect. 


\section{Introduction}

Recently, evidence has been accumulating that cyclic GMP (cGMP) plays a role in memory processes (e.g Bernabeu et al. 1996; Prickaerts et al. 2002a). Accordingly, inhibition of the cGMP hydrolysing phosphodiesterase type 5 (PDE5) may be an important tool to improve early consolidation of memory (see Prickaerts et al. 2004).

In vitro experiments demonstrated that the selective PDE5 inhibitors zaprinast, vardenafil and sildenafil increase NO-mediated cGMP accumulation in the dorsal hippocampus of rats as assessed with radioimmunoassay and immunocytochemistry (de Vente et al. 1996; Prickaerts et al. 2002a; van Staveren et al. 2001).

All these experiments have been performed in rat tissues. Recently, we observed that in the mouse hippocampus slice preparation cGMP-immunoreactivity was already observed in astrocytes without stimulation of a NO donor (van Staveren et al. 2004). Under similar conditions, such a pattern of cGMP-immunoreactivity has never been observed in the rat hippocampus. Thus, there are differences in the cellular localisation and activity of NO-mediated cGMP signalling between mouse and rat hippocampus. Nevertheless, the expression pattern of PDE 5 mRNA were not different between the species (van Staveren et al. 2004).

Considering the differences in NO mediated cGMP signalling mentioned above, the aim of the present study was to examine the memory-enhancing properties of PDE5 inhibitors in mice. For the first time the object recognition task (ORT) was used to study the effects of PDE5 inhibition, i.e. sildenafil, on the delay-dependent forgetting in mice.

In addition to the behavioural study, we evaluated the effects of PDE5 inhibition on cGMP-immunoreactivity (cGMP-IR) in hippocampal slices using cGMP immunocytochemistry in a separate experiment. Since NO, as a retrograde messenger, is assumed to mediate a presynaptic effect (Arancio et al. 2001; Son et al. 1998), we also analyzed whether cGMP immunoreactivity co-localized with the presynaptic marker synaptophysin.

\section{Materials and methods}

\section{Animals}

All experimental procedures were approved by the local ethical committee of the Maastricht University for animal experiments and met governmental guidelines. Ten 6-month-old male Swiss mice (Charles River, NL) were used for behavioral testing and four mice were used for immunocytochemistry. The animals were housed individually in standard Makrolon cages on sawdust bedding in an air-conditioned room (about $20^{\circ} \mathrm{C}$ ). The mice were not housed in the same room in which they were tested. A radio, which was playing softly, provided background noise in all rooms. All testing was done between 9.00 and maximally $16.00 \mathrm{~h}$. The animals were kept under a reversed 12/12-hour light/dark cycle (lights on from 18.00 to $6.00 \mathrm{~h}$ ) and had free access to food and water. 


\section{Object recognition memory}

The object recognition test was performed as described elsewhere (Sik et al. 2003). The apparatus consisted of a circular arena, $43 \mathrm{~cm}$ in diameter. Half of the $40 \mathrm{~cm}$ high wall was made of white polyvinyl chloride, the other half of transparent polyvinyl chloride. Fluorescent red tubes and a light bulb provided a constant illumination of about 20 lux on the floor of the apparatus. Two objects were placed symmetrically about $5 \mathrm{~cm}$ away from the white wall. Each object was available in triplicate. We used four different sets of objects. The different objects were: 1) a cone made of brass (maximal diameter $6 \mathrm{~cm}$ and total height $3.8 \mathrm{~cm}$ ), 2) a transparent glass bottle (diameter $2.7 \mathrm{~cm}$, height $8.5 \mathrm{~cm}$ ) filled with sand, 3) a massive metal cube $(2.5 \times 5 \times 7.5 \mathrm{~cm})$ with two holes (diameter $1.5 \mathrm{~cm})$, and 4$)$ a massive aluminum cube with a tapering top $(4.5 \times 4.5 \times 8.5 \mathrm{~cm})$. The objects could not be displaced by a mouse.

In the first week, the animals were handled daily and were adapted to the procedure in three days, i.e. they were allowed to explore the apparatus (without any objects) twice for $5 \mathrm{~min}$ each day. In the following two weeks, the mice were tested until they showed a good discrimination performance. A saline injection $(0.4 \mathrm{ml})$ was always given after the first exploration period to adapt the mice to the p.o. administrations. The next week, testing of the drugs began.

A testing session comprised of two trials. The duration of each trial was 3 min. During the first trial (T1) the apparatus contained two identical objects (samples). A mouse was always placed in the apparatus facing the wall at the middle of the front (transparent) segment. After the first exploration period, the mouse was put back in its home cage. Subsequently, after a predetermined delay interval (24h), the mouse was put back in the apparatus for the second trial (T2), but now with two dissimilar objects, a familiar one (the sample) and a new one. The times spent exploring each object during $\mathrm{T} 1$ and $\mathrm{T} 2$ were recorded manually using a personal computer.

Exploration was defined as follows: directing the nose to the object at a distance of no more than $2 \mathrm{~cm}$ and/or touching the object with the nose. Sitting on the object was not considered as exploratory behavior. In order to avoid the presence of olfactory cues the objects were always thoroughly cleaned before each trial. All combinations and locations of objects were used in a balanced manner to reduce potential biases due to preferences for particular locations or objects.

\section{Treatments}

The effects of sildenafil treatment on object memory performance were tested at different doses $(0.3,1$, and $3 \mathrm{mg} / \mathrm{kg}$ ). Sildenafil was freshly suspended in $1 \%$ Tylose (methyl-cellulose) on every experimental day. Since we expected sildenafil to improve memory performance, a $24 \mathrm{~h}$ delay interval between $\mathrm{T} 1$ and $\mathrm{T} 2$ was chosen. Administrations were always given immediately after the first trial (p.o.; in $5 \mathrm{ml} / \mathrm{kg}$ ). Two testing sessions were given each week, one session comprising Monday and Tuesday and the other one comprising Thursday and Friday. The doses were tested in a random order. Each dose condition was tested twice and the scores per condition were pooled for each mouse. 


\section{Tissue preparation}

The mice were decapitated and their brains were immediately transferred into ice-cold KrebsRinger bicarbonate buffer (Krebs buffer) of the following composition: $121.1 \mathrm{mM} \mathrm{NaCl}$, $1.87 \mathrm{mM} \mathrm{KCl}, 1.17 \mathrm{mM} \mathrm{KH}_{2} \mathrm{PO}_{4}, 1.15 \mathrm{mM} \mathrm{MgSO}_{4}, 26.2 \mathrm{mM} \mathrm{NaHCO}_{3}, 2.0 \mathrm{mM} \mathrm{CaCl}_{2}$ and $11.0 \mathrm{mM}$ glucose, aerated with $95 \% \mathrm{O}_{2}$ and $5 \% \mathrm{CO}_{2}$ at $\mathrm{pH} 7.4$.

Hippocampal slices $(300 \mu \mathrm{m})$ were cut using a Vibroslicer (Campden Instruments). Throughout the procedure, slices were kept under aeration with $95 \% \mathrm{O}_{2}$ and $5 \% \mathrm{CO}_{2}$. After sectioning in ice-cold Krebs buffer, slices were brought to room temperature and then transferred to incubation wells and incubated for 30 minutes at $35.5^{\circ} \mathrm{C}$ in Krebs buffer in the presence or absence of $10 \mu \mathrm{M}$ sildenafil. Next, the slices were incubated for another 10 minutes with or without $10 \mu \mathrm{M}$ diethylamino-NONOate (DEA/NO). Sildenafil was dissolved in DMSO and the controls contained the appropriate concentration of DMSO.

\section{Immunocytochemistry}

After the incubation period, slices were fixed with ice-cold fixative solution of $4 \%$ freshly prepared depolymerised paraformaldehyde in $0.1 \mathrm{M}$ phosphate buffer ( $\mathrm{pH} 7.4$ ) for 30 minutes at $4^{\circ} \mathrm{C}$. Thereafter, slices were fixed for another 90 minutes with $4 \%$ paraformaldehyde containing $10 \%$ sucrose. After washing at $4^{\circ} \mathrm{C}$ in $0.1 \mathrm{M}$ phosphate buffer $(\mathrm{pH} 7.4)$ containing $10 \%$ sucrose, slices were aligned in a plane and snap-frozen with $\mathrm{CO}_{2}$ in Tissue-Tek O.C.T. compound. Cryostat sections $(10 \mu \mathrm{m})$ were cut and thawed onto chromealumn/gelatin coated slides and processed for immunocytochemistry.

Frozen sections were dried for 20 minutes at room temperature, followed by three 5 min. washes with Tris-buffered saline (TBS). Sections were incubated overnight at $4^{\circ} \mathrm{C}$ with primary antibodies diluted in TBS containing 0.3\% Triton X-100 (TBS-T). cGMP was visualized with sheep anti-formaldehyde fixed cGMP (1:4000). The specificity of the cGMP antibody has been detailed elsewhere (De Vente et al. 1998). Sections were incubated with the anti-cGMP alone or in combination with anti-synaptophysin (1:500 in TBST). After incubation with primary antibodies, sections were washed with TBS-T, TBS and TBS-T; each step lasted at least $10 \mathrm{~min}$. For the visualization of the primary antibodies, sections were incubated with Alexa fluor 488 donkey anti-sheep IgG conjugate (1:100) for sheep antibodies, whereas anti-synaptophysin antiserum was visualized with CY-3 conjugated donkey anti-rabbit antiserum (1:800). Incubations with the secondary antibodies lasted for $90 \mathrm{~min}$ in the dark at room temperature. Thereafter, sections were washed 2 times in TBS-T and 1 time in TBS, and mounted with TBS-glycerol. Sections were examined using an Olympus AX-70 microscope equipped with an F-view cooled CCD camera. Images were stored as 8-bit files using Analysis ${ }^{\circledR}$ software, assembled using Adobe Photoshop 7.0.1, adjusting contrast and brightness both at a level of +30 . 


\section{Statistical analysis}

The basic measures were the times spent by mice exploring an object during T1 and T2. The time spent exploring the two identical samples will be represented by ' $a 1$ ' and ' $a 2$ '. The time spent in T2 exploring the sample and new object will be represented by ' $a$ ' and ' $b$ ', respectively. Based on these exploration times different parameters were calculated (see Table 1) (Sik et al. 2003).

Table 1. Measures involved in the object recognition test

\begin{tabular}{ccc}
\hline Exploration & Habituation & Discrimination \\
\hline$e 1=a 1+a 2$ & $h 1=e 1-e 2$ & $d 2=b-a / e 2$ \\
$e 2=a+b$ & & \\
\hline
\end{tabular}

$e 1$ is the measure of the time spent exploring both identical objects ( $a 1$ and $a 2$ ) in the first trial, and $e 2$ is the measure of the time spent exploring both the familiar (a) and new object $(b)$ in the second trial; $h 1$ is the measure of global habituation from trial 1 to trial $2 ; d 1$ and $d 2$ are the measures of discrimination between the new and familiar objects. In fact, $d 2$ is a relative measure of discrimination which corrects $d 1$ for exploration activity (e2). Since the nature of the exploration and discrimination measures is different, they were analyzed differently. For $e 1, e 2$ and $h 1$ the effects of the different dose conditions were analyzed with a within-subject repeated measures design (General Linear Model, GLM). Differences between dose conditions were calculated in more detail using a Bonferroni post-hoc test.

When assessing the discrimination performance, we are only interested whether the dose conditions differ from the untreated vehicle condition. To evaluate the discrimination we compared the $\mathrm{d} 2$ values of the different doses with the vehicle group using independent sample t-tests. To control for multiple comparisons, the critical $\alpha$ was divided by the number of comparisons made. Since three comparisons were made between the vehicle group and the three dose groups, the critical $\alpha$ was $0.05 / 3=0.017$.

\section{Results}

\section{Effects of Sildenafil treatment in the ORT}

The results of treatment with sildenafil are summarized in Table 2. Additional analysis of measures of location preference (left or right side of arena) or object preference showed no differences between conditions (data not shown). In T1 there was no difference between treatment sessions on the total level of exploration $(e 1: \mathrm{F}(3,27)=2.92$, n.s.). However, the total level of exploration $24 \mathrm{~h}$ after $\mathrm{T} 1$ was different between treatment conditions 
(e2: $\mathrm{F}(3,27)=5.51, P<0.01)$. Post-hoc comparisons showed that the level of exploration in the highest dose condition $(3 \mathrm{mg} / \mathrm{kg}$ ) was higher than in the vehicle condition. The exploration level in the other treatment conditions did not differ from the exploration level in the vehicle condition. The index measure of habituation of exploratory behavior h1 did not differ between treatment conditions (h1: $\mathrm{F}(3,27)=2.14$, n.s.).

Table 2. Results of treatment with Sildenafil on the measures of the object recognition test. Swiss mice ( $n=10$ per dose) received a p.o. injection of sildenafil at doses of $0,0.3,1$ or $3 \mathrm{mg} / \mathrm{kg}$ directly after the first trial. The delay between the first and the second trial was $24 \mathrm{~h}$.

\begin{tabular}{|c|c|c|c|c|}
\hline & VEHICLE & $0.3 \mathrm{mg} / \mathrm{kg}$ & $1 \mathrm{mg} / \mathrm{kg}$ & $3 \mathrm{mg} / \mathrm{kg}$ \\
\hline \multicolumn{5}{|c|}{ Mean values ( \pm S.E.M.) of total exploration time (s) during the first $(e 1)$ and second trial $(e 2)$} \\
\hline el & $13.15(1.98)$ & $17.73(2.39)$ & $11.96(1.55)$ & 15.69 \\
\hline e2 & $9.43(1.21)$ & $16.88(2.17)$ & $15.60(2.26)$ & $21.82(3.44)$ \\
\hline \multicolumn{5}{|c|}{ Mean values ( \pm S.E.M) of the global index of habituation $(h 1)$ from the first to the second trial } \\
\hline$h 1$ & $3.72(2.26)$ & $0.85(3.11)$ & $-3.64(3.01)$ & $-6.13(3.29)$ \\
\hline
\end{tabular}

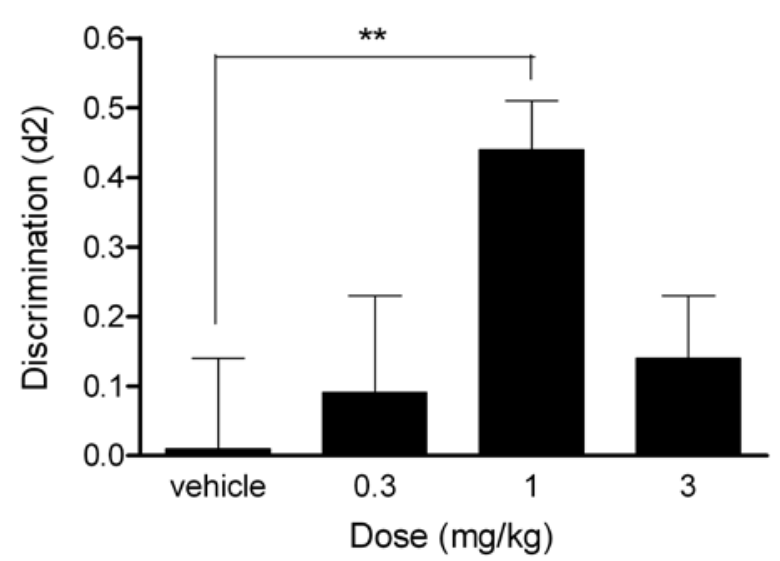

Figure 1: Effects of sildenafil treatment on the discrimination performance in an object recognition task in Swiss mice (means + S.E.M.). In the vehicle session, mice were treated with $0.1 \%$ Tylose solution. In the drug session, animals were treated with doses of $0.3,1$ and 3 $\mathrm{mg} / \mathrm{kg}$ sildenafil. Sildenafil improved the performance of the mice at the dose of $1 \mathrm{mg} / \mathrm{kg}$. Differences from the vehicle group are depicted by asterisks (** $\mathrm{d} 2>$ vehicle group; $\mathrm{P}<0.01$ ). 
The effects of treatment with sildenafil on the $d 2$ index are presented in figure 1 . When comparing the $d 2$ indices of the three dose conditions to the vehicle condition, only the $d 2$ value of the medium dose $(1 \mathrm{mg} / \mathrm{kg})$ was higher than the vehicle group $(\mathrm{t}=-2.86 ; P<0.01)$.

\section{Immunocytochemistry}

Incubation of mouse hippocampal slices in vitro in the absence of PDE inhibitors resulted in cGMP-positive astrocytes mainly in the CA1 area (not shown, see van Staveren et al. 2004). However, when the slices were incubated in the presence of $10 \mu \mathrm{M}$ sildenafil, cGMP-IR was additionally visualized in varicosities in the CA3 region of the hippocampus (Fig. 2a) and a number of short, thin fibers (Fig. 2c). Addition of $10 \mu \mathrm{M}$ DEA/NO to the incubation medium in the presence of $10 \mu \mathrm{M}$ sildenafil strongly increased the number of cGMP-IR varicosities in the CA3 region (Fig. 2e). Double immunostaining of cGMP-IR with synaptophysin did not reveal any co-localization of these markers under any circumstance (Fig. 2b, $d$ and f).

\section{Discussion}

\section{Behavioral studies}

As shown in a previous study, mice can be tested in the ORT and the relative discrimination index (d2) can be used as a measure of object memory in mice (Sik et al. 2003). The present study investigated the effect of the selective PDE5 inhibitor sildenafil on the object recognition task in mice. The levels of exploration did not differ between treatment conditions in the first trial. However, in the second trial the level of exploration for the vehicle condition was lower than for the highest dose condition $(3 \mathrm{mg} / \mathrm{kg}$ ). We do not have a clear explanation for the low exploration value for the vehicle group in the second trial, but levels of exploration were sufficient for a reliable assessment of discrimination performance in all treatment conditions. The habituation index is a measure for the difference in exploration times between T1 and T2. The measure of global habituation (h1) showed no differences between treatment conditions. Of note, the corrected discrimination index (d2) is regarded the key parameter for assessing discrimination performance.

This study shows that selective PDE5 inhibitors improve object memory performance in mice. In the vehicle treatment conditions the mice show no memory of the familiar object after 24 hours. However, administration of sildenafil (p.o.) directly after the first trial, improved object memory at the dose of $1 \mathrm{mg} / \mathrm{kg}$. Our findings corroborate previous data showing that sildenafil improves the performance in a passive avoidance task (Baratti and Boccia 1999). In addition, the present data extends the notion that inhibition of PDE5 can improve object memory in different species. 

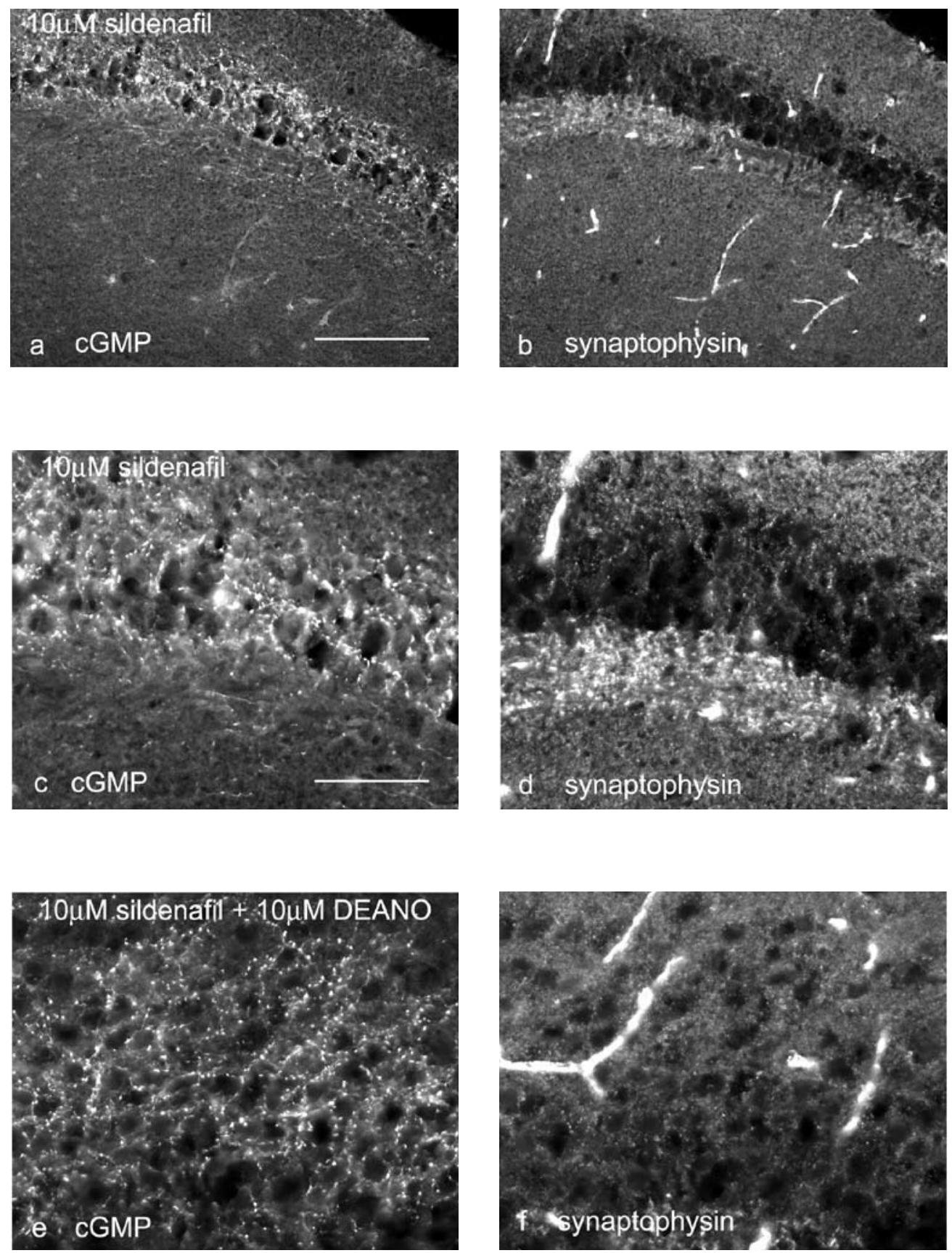

Figure 2: $c G M P-I R$ in hippocampal slices of the CA3 area. a,c) Slices incubated with $10 \mu \mathrm{M}$ sildenafil. 2e) Slices incubated with $10 \mu \mathrm{M}$ sildenafil and $10 \mu \mathrm{M}$ DEA/NO. b,d,f) Synaptophysin immunostaining of the same areas of the same sections as shown in a, c and e. Bars: $50 \mu \mathrm{m}$ for $\mathrm{a}$ and $\mathrm{b} ; 25 \mu \mathrm{m}$ for $\mathrm{c}-\mathrm{f}$. 


\section{Immunocytochemistry}

As discussed earlier, using rat brain slices and a selective PDE5 inhibitor, a NO donor is necessary for cGMP detection in the hippocampus (van Staveren et al. 2004). In the mouse hippocampus cGMP levels are already detectable without $\mathrm{NO}$ administration and even without PDE inhibitors in astrocytes. After administration of $10 \mu \mathrm{M}$ sildenafil, cGMP-IR was visualized in varicosities in the CA3 region of the hippocampus. Addition of a NO donor strongly increased cGMP-IR. In contrast to the differences in the levels of cGMP with or without stimulation with an NO donor in rats and mice, this effect of sildenafil appears to show a similarity between these two species. Accordingly, it can be suggested that the PDE5 inhibition leads to enhanced cGMP levels in varicosities in the hippocampal region in rodents. At present it is unknown whether the expression of cGMP in varicosities after PDE5 inhibition occurs in the same type of neurons.

Current concepts on the working mechanism of $\mathrm{NO}$ in strengthening synaptic contacts define a presynaptic effect of NO, in conjunction with the retrograde messenger role of NO (Garthwaite and Boulton 1995). The hippocampal slices incubated in the presence of $10 \mu \mathrm{M}$ sildenafil showed cGMP-IR within varicosities in the CA3 region of the hippocampus. Our present results do not demonstrate a colocalization of cGMP with synaptophysin in the CA3 region of the mouse hippocampus. However, when using $1 \mathrm{mM}$ IBMX as a PDE inhibitor we observed an occasional presence of cGMP in presynaptic structures identified by synaptophysin (van Staveren et al. 2004). Our results might indicate either that PDE5 is not present in presynaptic structures, or that cGMP cannot be detected in presynaptic structures under the prevailing conditions. This latter possibility is reminiscent to the situation observed in cerebellar Purkinje cells, where NO-mediated cGMP synthesis has been demonstrated (Hartell et al. 2001), although cGMP-IR has never been convincingly demonstrated in these cells for unknown reasons. It has been stated that the sensitivity of the immunocytochemical method might be too low to detect low levels of cGMP in these cells (see de Vente and Steinbusch 1992 for a detailed discussion). Nevertheless, it has also been argued that the detection level of the method might be between 0.1 and $1.0 \mu$ M cGMP (Tanaka et al. 1997), which is within the range of cGMP levels observed after stimulation of sGC. Although no colocalisation with synaptophysin and cGMP was found, the present findings do not rule out possible pre-synaptic cGMP activity. The presynaptic action of NO/sGC/cGMP is assumed to be part of the mechanism of E-LTP. Evidence has been presented that improvement of object recognition after sildenafil might in part be mediated by an effect on E-LTP (Ingram et al. 1996). The effects of sildenafil on memory we have observed are longer lasting, which implies that after induction of E-LTP its effects on memory outlast the period of E-LTP duration. It is possible that E-LTP is converted into L-LTP, as has been observed recently (Pang et al. 2004). Of note, the latter is associated with a postsynaptic localization. Considering the absence of colocalization of cGMP-immunoreactivity with synaptophysin, we conclude that sildenafil also acts postsynaptically. Recently, it was demonstrated that NO and cGMP act both pre- and postsynaptically during induction of a form of E-LTP (Wang et al. 2005). In ad- 
dition, a recent study (Lu and Hawkins 2002) showed that post synaptically localized cGMP contributes to L-LTP. To resolve this issue, studies are needed in which the PDE5 enzyme is localized at a subcellular level using a selective PDE5 antibody.

Moreover, the present study focused on the effects of PDE5 inhibition on cGMP-IR and memory function in the hippocampus. However, although cGMP activity was shown in the hippocampal slices, the involvement of other brain regions, such as the cerebellum or the peri/post-rhinal cortex, cannot be excluded on basis of the present data.

PDE5 inhibitors are known to result in vasodilatation, probably through cGMP in rats (Dundore et al. 1993; Dundore et al. 1992). Thus, the memory improving effect of PDE5 inhibitors may alternatively result from the increased blood flow, and consequently glucose metabolism in the brain. However, the PDE5 inhibitor zaprinast clearly improved object memory in rats at $10 \mathrm{mg} / \mathrm{kg}$ (i.p.) but did not affect mean arterial blood pressure at this dosage (Prickaerts et al. 1997). Similar results on object memory and blood pressure have been observed for sildenafil administration in rats (Prickaerts et al. 2004). Taking this into account, it is unlikely that the memory enhancing effects of PDE5 inhibitors in mice can simply be explained through changes in blood flow or blood pressure (for a more detailed review see: (Prickaerts et al. 2004). So far, no studies have investigated the effects of PDE5 inhibitors on arterial blood pressure and cerebral blood flow in mice.

In conclusion, PDE5 inhibition is an effective way to improve object recognition memory in both rats and mice. Further experiments will be required to investigate the pathways underlying PDE5 inhibition and the localization of PDE5 and cGMP in the hippocampal neurons.

\section{References}

Arancio O, Antonova I, Gambaryan S, Lohmann SM, Wood JS, Lawrence DS, Hawkins RD (2001) Presynaptic role of cGMP-dependent protein kinase during long-lasting potentiation. J. Neurosci. 21: 143-9

Baratti CM, Boccia MM (1999) Effects of sildenafil on long-term retention of an inhibitory avoidance response in mice. Behav. Pharmacol. 10: 731-737

Bernabeu R, Schmitz P, Faillace MP, Izquierdo I, Medina JH (1996) Hippocampal cGMP and cAMP are differentially involved in memory processing of inhibitory avoidance learning. Neuroreport 7: 585-588

De Vente J, Hopkins DA, Markerink-van Ittersum M, Emson PC, Schmidt HHW, Steinbusch H (1998) Distribution of nitric oxidesynthase and nitric oxide-receptive, cyclic GMP-producing structures in the rat brain. Neuroscience 87: 207-241

de Vente J, Hopkins DA, Markerink-van Ittersum M, Steinbusch HW (1996) Effects of the 3',5'-phosphodiesterase inhibitors isobutylmethylxanthine and zaprinast on NO-mediated cGMP accumulation in the hippocampus slice preparation: an immunocytochemical study. J. Chem. Neuroanat 10: 241-248

de Vente J, Steinbusch HW (1992) On the stimulation of soluble and particulate guanylate cyclase in the rat brain and the involvement of nitric oxide as studied by cGMP immunocytochemistry. Acta Histochem. 92: 13-38

Dundore RL, Clas DM, Wheeler LT, Habeeb PG, Bode DC, Buchholz RA, Silver PJ, Pagani ED (1993) Zaprinast increases cyclic GMP levels in plasma and in aortic tissue of rats. Eur. J. Pharmacol. 249: 293-7

Dundore RL, Habeeb PG, Pratt PF, Becker LT, Clas DM, Buchholz RA (1992) Differential hemodynamic responses to selective inhibitors of cyclic nucleotide phosphodiesterases in conscious rats. J. Cardiovasc. Pharmacol. 19: 937-44 
Garthwaite J, Boulton CL (1995) Nitric oxide signaling in the central nervous system. Annu. Rev. Physiol. 57: 683-706

Hartell NA, Furuya S, Jacoby S, Okada D (2001) Intercellular action of nitric oxide increases cGMP in cerebellar Purkinje cells. Neuroreport 12: 25-28

Ingram DK, Shimada A, Spangler EL, Ikari H, Hengemihle J, Kuo H, Greig N (1996) Cognitive enhancement. New strategies for stimulating cholinergic, glutamatergic, and nitric oxide systems. Ann. N. Y. Acad. Sci. 786:348-61

Lu YF, Hawkins RD (2002) Ryanodine receptors contribute to cGMP-induced late-phase LTP and CREB phosphorylation in the hippocampus. J. Neurophysiol. 88: 1270-8

Pang PT, Teng HK, Zaitsev E, Woo NT, Sakata K, Zhen S, Teng KK, Yung WH, Hempstead BL, Lu B (2004) Cleavage of proBDNF by tPA/plasmin is essential for long-term hippocampal plasticity. Science 306: 487-91

Prickaerts J, de Vente J, Honig W, Steinbusch HW, Blokland A (2002) cGMP, but not cAMP, in rat hippocampus is involved in early stages of object memory consolidation. Eur. J. Pharmacol. 436: 83-87

Prickaerts J, Sik A, van Staveren WC, Koopmans G, Steinbusch HW, van der Staay FJ, de Vente J, Blokland A (2004) Phosphodiesterase type 5 inhibition improves early memory consolidation of object information. Neurochem. Int. 45: 915-928

Prickaerts J, Steinbusch HW, Smits JF, de Vente J (1997) Possible role of nitric oxide-cyclic GMP pathway in object recognition memory: effects of 7-nitroindazole and zaprinast. Eur. J. Pharmacol. 337: 125-136

Sik A, van Nieuwehuyzen P, Prickaerts J, Blokland A (2003) Performance of different mouse strains in an object recognition task. Behav. Brain. Res. 147: 49-54

Son H, Lu YF, Zhuo M, Arancio O, Kandel ER, Hawkins RD (1998) The specific role of cGMP in hippocampal LTP. Learn. Mem. 5: 231-45

Tanaka J, Markerink-van Ittersum M, Steinbusch HW, De Vente J (1997) Nitric oxide-mediated cGMP synthesis in oligodendrocytes in the developing rat brain. Glia 19: 286-297

van Staveren WC, Markerink-van Ittersum M, Steinbusch HW, de Vente J (2001) The effects of phosphodiesterase inhibition on cyclic GMP and cyclic AMP accumulation in the hippocampus of the rat. Brain. Res. 888: 275-286

van Staveren WC, Steinbusch HW, Markerink-van Ittersum M, Behrends S, de Vente J (2004) Species differences in the localization of cGMP-producing and NO-responsive elements in the mouse and rat hippocampus using cGMP immunocytochemistry. Eur. J. Neurosci. 19: 2155-2168

Wang HG, Lu FM, Jin I, Udo H, Kandel ER, de Vente J, Walter U, Lohmann SM, Hawkins RD, Antonova I (2005) Presynaptic and postsynaptic roles of NO, cGK, and RhoA in long-lasting potentiation and aggregation of synaptic proteins. Neuron 45: 389-403 



\title{
ROLIPRAM REVERSES SCOPOLAMINE-INDUCED AND TIME-DEPENDENT MEMORY DEFICITS IN OBJECT RECOGNITION BY DIFFERENT MECHANISMS OF ACTION
}

\author{
K. Rutten, J. Prickaerts And A. Blokland.
}

Neurobiology of Learning and Memory (2006) 85: 132-138

In this study, the effect of the selective phosphodiesterase type 4 (PDE4) inhibitor rolipram on memory performance was investigated using the object recognition task. First, three doses of rolipram $(0.01,0.03$ or $0.1 \mathrm{mg} / \mathrm{kg}$ ) were tested with a $24 \mathrm{~h}$ delay between the learning (T1) and the test (T2) trial. Doses of rolipram were injected at different time points (30 min before T1, immediately after T1 or $3 \mathrm{~h}$ after T1). In a second experiment, the effects of rolipram $(0.03,0.1$ or $0.3 \mathrm{mg} / \mathrm{kg})$ were tested in combination with scopolamine $(0.1 \mathrm{mg} / \mathrm{kg})$ applying a $1 \mathrm{~h}$ delay between trials. Both substances were administered 30 min before T1. Using a $24 \mathrm{~h}$ interval, rolipram showed an improvement in long-term memory performance when injected $3 \mathrm{~h}$ after T1 at a dose of $0.03 \mathrm{mg} / \mathrm{kg}$. Further, rolipram reversed the scopolamine-induced short-term memory deficit at a dose of $0.1 \mathrm{mg} / \mathrm{kg}$. Although the improved memory performance in both conditions is likely to be explained by elevated cAMP levels, two separate working mechanisms might explain these effects. 


\section{Introduction}

Cyclic adenosine monophosphate (cAMP) plays an important role in intracellular signaling (Bailey et al. 1996) and in processes of neuroplasticity such as long term potentiation (LTP). Hippocampal LTP has been proposed to be a neurophysiological correlate of memory (Bliss and Collingridge 1993). LTP consists of two phases, an early phase (E-LTP), which does not require gene transcription and lasts less than 3 hours and a late phase (L-LTP) depending on gene transcription and protein synthesis and which lasts longer ( $>3 \mathrm{~h}$ ). The postsynaptic cAMP/ protein kinase A (PKA)/cAMP responsive element binding protein (CREB) pathway, as well as the postsynaptic cGMP/PKG/CREB pathway, are involved in L-LTP (Frey et al. 1993; Impey et al. 1996; Lu and Hawkins 2002; Lu et al. 1999; Slack and Walsh 1995).

Rolipram is a selective inhibitor of the phosphodiesterase type 4 (PDE4) enzyme, which hydrolyzes cAMP. Thus, PDE4 inhibition enhances the intracellular availability of cerebral cAMP in the absence of direct stimulation of neurotransmitter receptors (Silvestre et al. 1999). Studies investigating PDE4 function using rolipram indicate that CAMP is involved in neural processes that underlie learning and memory (Bach et al. 1999; Barad et al. 1998; Zhang and O'Donnell 2000). Accordingly, a substantial amount of studies have shown a positive effect of PDE4 inhibition on spatial memory (Bach et al. 1999; Gong et al. 2004; Nagakura et al. 2002), inhibitory avoidance learning (Egawa et al. 1997; Ghelardini et al. 2002; Imanishi et al. 1997; Randt et al. 1982; Zhang et al. 2000; Zhang and O’Donnell 2000), contextual fear conditioning (Barad et al. 1998; Gong et al. 2004) and object recognition memory (Bourtchouladze et al. 2003). Moreover, several studies have shown an involvement of PDE4 inhibitiors in working and reference memory (Egawa et al. 1997; Zhang et al. 2000; Zhang and O'Donnell 2000; Zhang et al. 2004).

Previous work showed that intra-hippocampal infusion of 8Br-cAMP improved memory performance when injected 3 or $6 \mathrm{~h}$ after one-trial training, but not when injected directly after the training trial (Bernabeu et al. 1997; Bernabeu et al. 1996; Prickaerts et al. 2002a). There is additional evidence that the late phase of memory consolidation is modulated by a cAMP/PKA signaling pathway in the hippocampus (Bernabeu et al. 1997). To our knowledge, all studies that claim to improve memory performance via the cAMP/PKA pathway administered rolipram before the training trial. However, the late phase of memory consolidation, in which the cAMP/PKA pathway is involved, occurs approximately three hours after training. At this time point cAMP levels are probably minimal due to its metabolic clearance (T1/2 = 1-3 h, Krause and Kuhne 1988). Therefore, another mechanism of action is probably responsible for the memory enhancing effects of rolipram when injected before T1. However, to our knowledge there is no profound evaluation of the effects of cAMP on early versus late consolidation. Furthermore, most cAMP evaluating studies have investigated the effects of cAMP via rolipram treatment in a scopolamine-induced short-term memory deficit model. Therefore, we decided to test the effects of rolipram on long-term memory performance by administering the drug at different time points. 
To study the memory enhancing properties of rolipram we investigated its effects in an object recognition task (ORT) (Ennaceur and Delacour 1988). The ORT is a memory test that relies on a rat's innate explorative behavior. In the first trial the animal is presented two objects. In the second trial, after a variable delay, one familiar and one new object are presented. In both trials the amount of time spent exploring the objects is recorded. If an animal has memory of the objects presented in trial 1 (T1), it will explore the novel object more in the second trial (T2). Depending on the time of treatment, drug effects on acquisition, consolidation or retrieval of object memory can be tested (Prickaerts et al. 2005). Treatments before the first trial influence acquisition or early consolidation processes, whereas treatments after T1 will affect early or late consolidation processes. The present study investigated the effects of different doses of rolipram on different long-term memory processes, i.e. acquisition (by injecting the drug 30 min before T1), early (by injecting the drug immediately after $\mathrm{T} 1$ ) and late (by injecting the drug $3 \mathrm{~h}$ after T1) consolidation, by using a $24 \mathrm{~h}$ delay. In addition, rolipram was tested in the scopolamine model for short-term memory deficits using a 1 h delay. This was done to replicate previous findings and for comparison of different doseresponse curves, i.e. long-term vs. short-term memory. Of note, the effects of rolipram on the scopolamine deficit model were never before examined in the object recognition task.

\section{Methods}

\section{Experiment 1: Effects of rolipram on long-term memory, using a $24 \mathrm{~h}$ interval in the ORT}

\section{Animals}

All experimental procedures were approved by the local ethical committee of the Maastricht University for animal experiments according to governmental guidelines. Twelve 5-monthold male Wistar rats (Charles River, The Netherlands) were used (413-464g). The animals were housed individually in standard type 3 Makrolon cages on sawdust bedding in an airconditioned room (about $20^{\circ} \mathrm{C}$ ). They were kept under a reversed 12/12-hour light/dark cycle (lights on from 18.00 to $6.00 \mathrm{~h}$ ) and had free access to food and water. Rats were housed in the same room as where the animals were tested. A radio, that played softly, provided background noise in all rooms. All testing was done between 9.00 and 17.00h.

\section{Object recognition memory}

The object recognition test was performed as described elsewhere (Prickaerts et al. 2002a). The apparatus consisted of a circular arena, $83 \mathrm{~cm}$ in diameter. Half of the $40 \mathrm{~cm}$ high wall was made of grey polyvinyl chloride, the other half of transparent polyvinyl chloride. A light bulb was switched on during testing only and provided a light intensity (20 lux) which was equal in the different parts of the apparatus. Two objects were placed in a symmetrical posi- 
tion about $10 \mathrm{~cm}$ away from the grey wall. We used four different sets of objects. The different objects were: 1) a cone consisting of a grey polyvinyl chloride base (maximal diameter $18 \mathrm{~cm}$ ) with a collar on top made of brass (total height $16 \mathrm{~cm}$ ), 2) a standard 11 transparent glass bottle (diameter $10 \mathrm{~cm}$, height $22 \mathrm{~cm}$ ) filled with sand, 3) a massive metal cube $(10.0 \times 5.0 \times 7.5 \mathrm{~cm})$ with two holes (diameter $1.9 \mathrm{~cm})$, and 4$)$ a massive aluminum cube with a tapering top $(13.0 \times 8.0 \times 8.0 \mathrm{~cm})$. The objects could not be displaced by a rat.

In the first week, the animals were handled daily and were adapted to the procedure in two days, i.e., they were allowed to explore the apparatus (without any objects) twice for 3 min each day. In the two following weeks the rats were adapted to the testing and i.p. administration procedure by a saline injection $(0.4 \mathrm{ml})$ immediately after the first trial until they showed a stable discrimination performance, i.e., good object discrimination at a 1 -h interval. Subsequently, testing of the drugs began.

A testing session comprised two trials. The duration of each trial was 3 min. During the first trial (T1) the apparatus contained two identical objects (samples). A rat was always placed in the apparatus facing the wall in the centre of the transparent front segment. After the first exploration period the rat was put back in its home cage. Subsequently, after a delay interval, the rat was put back in the apparatus for the second trial (T2), but now with two dissimilar objects, a familiar one (the sample) and a new one. The times spent exploring each object during T1 and T2 were recorded manually with a personal computer.

Exploration was defined as follows: directing the nose to the object at a distance of no more than $2 \mathrm{~cm}$ and/or touching the object with the nose. Sitting on the object was not considered exploratory behavior. In order to avoid the presence of olfactory trails the objects were always thoroughly cleaned. Moreover, each object was available in triplicate so neither of the two objects from the first trial had to be used as the familiar object in the second trial. In addition, all combinations and locations of objects were used in a balanced manner to reduce potential biases due to preferences for particular locations or objects.

Since we expected the drug treatments to improve long-term memory performance we needed a delay interval at which no more discrimination between the objects occurs. Therefore, we selected a delay interval of $24 \mathrm{~h}$, since Wistar rats show virtually no discrimination between the two objects after this interval (Prickaerts et al. 2002b). In one week two testing sessions were given, one session comprised Monday and Tuesday and the other one comprised Thursday and Friday.

In the first experiment we investigated the effects of rolipram on object recognition memory using a 24h delay interval and three different times of administration.

\section{Treatment with rolipram}

Rolipram was freshly suspended in 5\% ethanol, 1\% tylose (methyl-cellulose) and 94\% distilled water on every experimental day. The following doses of rolipram were tested: 0.01 , 0.03 or $0.1 \mathrm{mg} / \mathrm{kg}$. Administrations were always i.p. (injection volume $2 \mathrm{ml} / \mathrm{kg}$ ) at three different time points. First, effects of rolipram were investigated when injected 30 minutes before T1. Next, rolipram was injected immediately after T1 and in the final study injections 
took place three hours after T1. Each dose condition was tested once. The order of the dose testing was randomly chosen.

\section{Statistical analysis}

The basic measures were the times spent by rats in exploring an object during $\mathrm{T} 1$ and T2. Table 1 shows the measures involved in the object recognition task (Prickaerts et al. 1997). $e 1$ and $e 2$ are measures of the total exploration time of both objects during $\mathrm{T} 1$ and $\mathrm{T} 2$ respectively. $\mathrm{d} 2$ was considered as index measures of discrimination between the new and the familiar objects. In fact, $d 2$ is a relative measure of discrimination which corrects the difference between exploring the old and the novel object for exploration activity (e2).

For all parameters the effects of the different dose conditions were analyzed with a one way ANOVA. Dose effects were analyzed in more detail with t-test using Duncan post hoc test correction.

Table 1. Measures involved in the object recognition test $e 1$ is the measure of the time spent in exploring both identical objects ( $a 1$ and $a 2$ ) in T1, and $e 2$ is the measure of the time spent in exploring both the familiar ( $a$ ) and new object $(b)$ in T2; $d 2$ is the measure of discrimination between the new and familiar objects.

\begin{tabular}{cc}
\hline Exploration & Discrimination \\
\hline$e 1=a 1+a 2$ & $d 2=b-a / e 2$ \\
$e 2=a+b$ & \\
\hline
\end{tabular}

\section{Experiment 2: Effect of rolipram on short-term memory in the scopolamine model for amnesia, using a $1 \mathrm{~h}$ delay in the ORT.}

\section{Animals}

For this experiment twelve 4-month-old male Wistar rats (390-452g) were used. Housing conditions were identical to those described in Experiment 1.

\section{Object recognition memory}

The apparatus and procedures of the object recognition test were identical to those described in Experiment 1 (see above). However, the second experiment was based on a one hour delay interval between T1 and T2. Under normal conditions, Wistar rats show a good memory performance using this interval. Therefore, the effects of rolipram were investigated in a scopolamine-induced memory deficit model. 


\section{Treatment with scopolamine and rolipram}

Scopolamine (0.1 mg/kg in saline; s.c.) in combination with rolipram $0.03,0.1$ or $0.3 \mathrm{mg} / \mathrm{kg}$ in vehicle (see exp. 1; i.p.) were administrated 30 minutes before T1. Each treatment combination was tested once. The order of dose-testing was chosen randomly.

\section{Statistical analysis}

The parameters in the second experiment were identical to those described in Experiment 1 (see above). For all parameters the effects of the different dose conditions were analyzed with a one way ANOVA. Post-hoc comparisons were made in case of significance (LSD).

\section{Results}

\section{Experiment 1: Effects of Rolipram in the 24h delay ORT}

\section{Treatment: 30 minutes before $\mathrm{T} 1$}

The results of treatment with rolipram 30 minutes before the first trial are summarized in Table 2A. No location preference was found in any of the treatment sessions (data not shown). In $\mathrm{T} 1$ the total level of exploration was different between treatment conditions $(e 1: F(3,43)=5.17, P<0.01)$. Post-hoc comparisons showed that the level of exploration in the highest dose condition $(0.1 \mathrm{mg} / \mathrm{kg})$ was lower than in the other treatment conditions (Duncan post-hoc). For T2 no difference between treatment sessions in the total level of exploration was observed (e2: $\mathrm{F}(3,43)=2.34$, n.s. $)$.

The effects of treatment with rolipram, 30 minutes before $\mathrm{T} 1$, on the $d 2$ index are presented in Figure 1A. A between group comparison (ANOVA) showed no significant dose effect for d2 $(d 2: F(4,43)=0.31$; n.s.). There were no differences in discrimination performance between treatment conditions.

\section{Treatment: immediately after $\mathrm{T} 1$}

When rolipram was administered immediately after $\mathrm{T} 1$ no location preference was found in any of the treatment sessions (data not shown). In $\mathrm{T} 1$ there was a difference between treatment sessions in the total level of exploration $(e 1: \mathrm{F}(3,46)=5.63, P<0.01)$ (Table 2B). In a post-hoc analysis we found that the level of exploration was higher for the $0.1 \mathrm{mg} / \mathrm{kg}$ dose condition than for the $0.03 \mathrm{mg} / \mathrm{kg}$ dose condition (Duncan test). There were no differences between the other dose conditions. It is very likely that the effect on e1 before rolipram treatment is an incidental statistical effect which, cannot be linked to rolipram since it was given after $\mathrm{T} 1$. The level of exploration in $\mathrm{T} 2$ did not differ between treatment sessions $(e 2: \mathrm{F}(3,46)=1.51$, n.s. $)$. 
The effects of treatment with rolipram, immediately after $\mathrm{T} 1$, on the $\mathrm{d} 2$ index are presented in Figure 1B. A between group comparison (ANOVA) showed no significant dose effect for $d 2(d 2: F(4,46)=0.90 ;$ n.s. $)$ when rolipram was injected immediately after T1. None of the treatment conditions differed in discrimination performance.

Table 2. Results of treatment with rolipram on the exploration measures of the object recognition test. Wistar rats ( $\mathrm{n}=12$ per dose) received an i.p. injection of rolipram at doses of 0, 0.01, 0.03 or $0.1 \mathrm{mg} / \mathrm{kg}$. The delay between the first and the second interval was $24 \mathrm{~h}$.

${ }^{*} P<0.05$ : different from vehicle (Duncan); \# $P<0.05$ : different from $0.03 \mathrm{mg} / \mathrm{kg}$ (Duncan) Mean values ( \pm S.E.M.) of total exploration time (s) during the first (e1) and second trial (e2)

\begin{tabular}{|c|c|c|c|c|}
\hline & VEHICLE & $0.01 \mathrm{mg} / \mathrm{kg}$ & $0.03 \mathrm{mg} / \mathrm{kg}$ & $0.1 \mathrm{mg} / \mathrm{kg}$ \\
\hline \multicolumn{5}{|c|}{ A) Injection 30 min before $\mathrm{T} 1$} \\
\hline el & $23.85(4.07)$ & $15.97(3.18)$ & $18.46(2.52)$ & $7.00(1.48) *$ \\
\hline$e 2$ & $29.55(3.78)$ & $17.67(1.89)$ & $25.53(3.24)$ & $22.69(3.42)$ \\
\hline \multicolumn{5}{|c|}{ B) Injection immediately after T1 } \\
\hline el & $15.63(2.02)$ & $18.38(1.70)$ & $11.93(0.97)$ & $21.86(2.20) \#$ \\
\hline$e 2$ & $15.73(2.22)$ & $20.51(2.23)$ & $20.43(2.13)$ & $16.61(1.53)$ \\
\hline \multicolumn{5}{|c|}{ C) Injection 3h after T1 } \\
\hline el & $31.52(2.95)$ & $24.67(2.72)$ & $32.18(3.14)$ & $30.20(2.39)$ \\
\hline$e 2$ & $33.24(3.42)$ & $27.27(2.24)$ & $27.62(2.71)$ & $31.82(3.73)$ \\
\hline
\end{tabular}
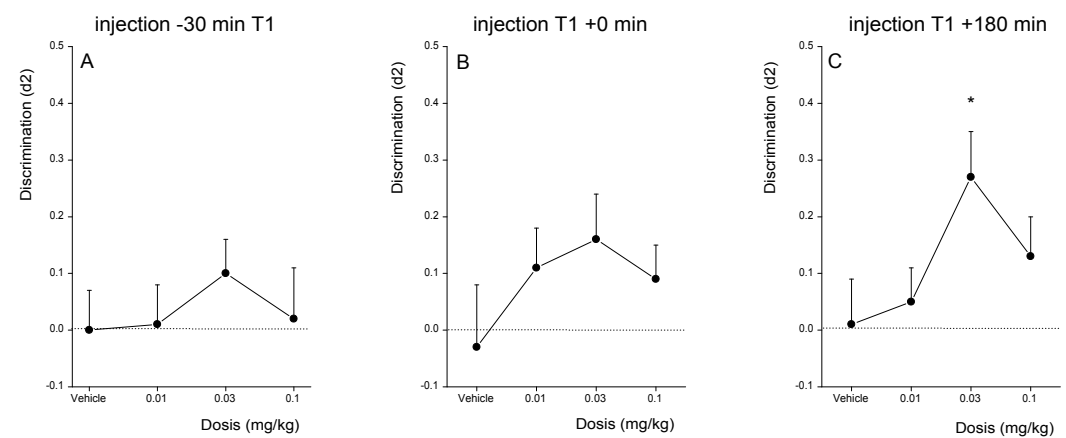

Figure 1: Effects of rolipram treatment on the discrimination performance in the object recognition task (means + S.E.M.). The delay between the learning trial (T1) and the test trial (T2) was $24 \mathrm{~h}$. In the vehicle session, rats were treated with 5\% ethanol, 1\% tylose (methylcellulose) solution (i.p.). In the drug session, rats were treated with doses of $0.01,0.03$ or $0.10 \mathrm{mg} / \mathrm{kg}$. Rolipram, when injected $30 \mathrm{~min}$ before T1 (A) or immediately after T1 (B) did not improve the performance of the animals at any dose condition. (C) Administration of rolipram $3 \mathrm{~h}$ after $\mathrm{T} 1 \mathrm{improved}$ the performance of the animals at the dose of $0.03 \mathrm{mg} / \mathrm{kg}$. Differences from the vehicle group are depicted as asterisks (One sample t-test; ${ }^{*} \mathrm{P}<0.05$ ). 


\section{Treatment: 3 h after T1}

The results of treatment with rolipram 3 hours after T1 are summarized in Table 2C. No location preference was found in any of the treatment conditions (not shown). There were no differences between treatment conditions in the total levels of exploration in $\mathrm{T} 1$ (e1: $\mathrm{F}(3.47)=1.47$, n.s.). Furthermore, no differences were observed between the dose conditions in the total level of exploration in $\mathrm{T} 2(e 2: \mathrm{F}(3,47)=0.95$, n.s.).

The effects of treatment with rolipram, $3 \mathrm{~h}$ after $\mathrm{T} 1$, on the $\mathrm{d} 2$ index are presented in Figure 1C. Between group analysis showed an effect of dose on the $\mathrm{d} 2$ values ( $d 2$ : $\mathrm{F}(3,47)=2.80 ; P<0.05)$ When comparing the different doses with the vehicle group with a post-hoc test, the $\mathrm{d} 2$ value of the medium dose $(0.03 \mathrm{mg} / \mathrm{kg})$ was higher than that of the vehicle group (Duncan test). Thus, 24 hours after training, only the rats treated with 0.03 $\mathrm{mg} / \mathrm{kg}$ rolipram were able to discriminate between the objects.

\section{Experiment 2: Effects of Rolipram on the scopolamine-induced memory impairment in the $1 \mathrm{~h}$ delay ORT}

The results of scopolamine treatment in combination with rolipram on the measures of exploration are shown in Table 3. When comparing between treatment groups an effect of dose on the levels of exploration in T1 was found ( $e 1$ : $F(4,53)=2.70 ; P<0.05)$. Post-hoc analysis showed that the level of exploration of the animals treated with the highest dose of rolipram $(0.3 \mathrm{mg} / \mathrm{kg})$ was lower than the other treatment conditions in T1 (LSD). The level of exploration in T2 did not differ between the different treatment conditions (e2: $\mathrm{F}(4,53)=0.87 ;$ n.s. $)$.

The effects of scopolamine and rolipram treatment on the $d 2$ index for object recognition are shown in Figure 2. Between group analysis showed a tendency of dose-effect on the $d 2$ values $(F(4,53)=1.86$; n.s. $)$. However, when comparing the different doses with post-hoc analysis, the $d 2$ values of the medium dose $(0.1 \mathrm{mg} / \mathrm{kg})$ and the no drugs condition (saline/ vehicle) were significantly higher than the $d 2$ value of the virtual group (LSD: $P<0.05$ ). Thus, scopolamine clearly impaired memory performance in a one hour delay version of the ORT and $0.1 \mathrm{mg} / \mathrm{kg}$ rolipram effectively reversed this memory deficit (Figure 2).

\section{Discussion}

In the present study we found that rolipram reverses the time-dependent decreased memory performance in object recognition when injected $3 \mathrm{~h}$ after the acquisition trial. Since rolipram did not improve memory when injected 30 min before T1 or immediately after T1 it is assumed that PDE4 inhibition improves late-phase consolidation. Corroborating previous studies, rolipram reversed the scopolamine-induced deficit. Notably, the dose of rolipram required to reverse the scopolamine deficit $(0.1 \mathrm{mg} / \mathrm{kg})$ was higher when compared to the dose required to reverse the time-dependent deficit $(0.03 \mathrm{mg} / \mathrm{kg})$. 
Table 3: Results of treatment with scopolamine in combination with rolipram on the exploration measures of the object recognition test. Wistar rats ( $\mathrm{n}=12$ per dose) received injections of scopolamine $(0.1 \mathrm{mg} / \mathrm{kg}$; s.c.) immediately followed by rolipram at doses of $0,0.03,0.1$ or $0.3 \mathrm{mg} / \mathrm{kg}$ (i.p.). The delay between the first and the second interval was 1 h. ${ }^{*} P<0.05$ : different from all other treatment conditions (LSD). Mean values ( \pm S.E.M.) of total exploration time (s) during the first (e1) and second trial (e2)

\begin{tabular}{cccccc}
\hline Scopolamine & $0 \mathrm{mg} / \mathrm{kg}$ & $0.1 \mathrm{mg} / \mathrm{kg}$ & $0.1 \mathrm{mg} / \mathrm{kg}$ & $0.1 \mathrm{mg} / \mathrm{kg}$ & $0.1 \mathrm{mg} / \mathrm{kg}$ \\
Rolipram & $0 \mathrm{mg} / \mathrm{kg}$ & $0 \mathrm{mg} / \mathrm{kg}$ & $0.03 \mathrm{mg} / \mathrm{kg}$ & $0.1 \mathrm{mg} / \mathrm{kg}$ & $0.3 \mathrm{mg} / \mathrm{kg}$ \\
\hline e1 & $19.46(2.61)$ & $16.25(2.23)$ & $24.01(3.90)$ & $17.90(6.84)$ & $5.80(9.07)^{*}$ \\
$e 2$ & $23.23(2.69)$ & $21.73(2.70)$ & $28.01(4.42)$ & $23.45(3.19)$ & $20.14(2.10)$ \\
\hline
\end{tabular}

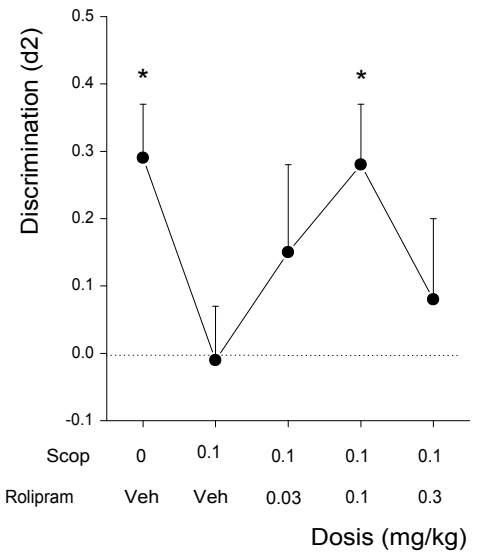

Rolipram increases intracellular cAMP levels in hippocampal slices (Barad et al. 1998). In the hippocampus cAMP is involved in L-LTP via the cAMP/PKA/CREB pathway (Bailey et al. 1996; Frey et al. 1993; Impey et al. 1996). Since the hippocampus plays an important role in long-term object recognition memory (Hammond et al. 2004; Prickaerts et al. 2002a), our results may imply an effect of rolipram in the process of hippocampal L-LTP, which is most effective when administered $3 \mathrm{~h}$ after T1. This effect was also shown to be dose-dependent.

Our data corroborate the findings of Bernabeu (1997) that intra-hippocampal injections of 8 Br-cAMP were only effective when administered 3 or 6 hours after training in the passive avoidance task. Along similar lines, administration of 8Br-cAMP was ineffective when given immediately after training in the ORT (Prickaerts et al. 2002a). Taking into account that the half-life of rolipram is approximately 1-3 h (Krause and Kuhne 1988), administering rolipram before or immediately after training in the object recognition task is not likely to enhance memory processes via cAMP. 
Mice carrying a truncated form of CREB-binding protein (CBP) show defective longterm object recognition memory. Treatment of these $\mathrm{CBP}^{+/-}$mice with rolipram reverses the long-term memory deficits (Bourtchouladze et al. 2003). In that study rolipram was administered 20 min before the first trial, thus possibly affecting acquisition or early consolidation processes. However, acquisition or early consolidation processes were not affected by rolipram in our experiment applying a $24 \mathrm{~h}$ delay, since administration of rolipram $30 \mathrm{~min}$ before $\mathrm{T} 1$ or immediately after T1 did not improve object recognition memory. Most probably the effects in the $\mathrm{CBP}+$ /- mice cannot be explained by rolipram enhancing late-phase consolidation. Thus, late consolidation occurs $3 \mathrm{~h}$ after $\mathrm{T} 1$ when rolipram levels are probably too low to affect cAMP levels in the brain. However, the effective dose for rolipram in that study was $0.1 \mathrm{mg} / \mathrm{kg}$, which is higher than the $0.03 \mathrm{mg} / \mathrm{kg}$ used in our time-dependent experiment. Therefore, it could be suggested that rolipram enhances neurotransmitter levels (see below) and this may explain the effects of rolipram on long-term memory in these mice.

Several studies have shown an ameliorating effect of rolipram on the scopolamineinduced memory deficit (Imanishi et al. 1997; Silvestre et al. 1999; Zhang and O’Donnell 2000). In the present study we also investigated the effects of rolipram on a scopolamineinduced deficit in the ORT. When rolipram $(0.1 \mathrm{mg} / \mathrm{kg})$ was administered together with scopolamine 30 minutes before training, rats were able to discriminate between the familiar and novel object. Several others have found ameliorating effects of rolipram on the scopolamine deficit in behavioral testing, using the similar doses of rolipram (Barad et al. 1998; Egawa et al. 1997; Imanishi et al. 1997; Silvestre et al. 1999; Zhang and O’Donnell 2000). However, this has never been shown before in the ORT. Since in this paradigm of the ORT short-term memory is examined, no gene transcription or protein synthesis is required. Thus, the CAMP/PKA/CREB pathway may not be involved. Of note, rolipram also affects the cholinergic system that is specifically disrupted by the treatment with scopolamine and this is mediated via an elevation of intracellular cAMP (Silvestre et al. 1999). Accordingly, cAMP analogues have been reported to promote the activity of cholinergic neurons and to potentiate acetylcholine (ACh) responses (Imanishi et al. 1997). Since, PDE4 inhibitors are able to increase cAMP levels and thus enhance ACh release and synthesis in the brain, it can be assumed that some of the pharmacological and behavioral effects of rolipram in the scopolamine model could be mediated by this neurotransmitter (Silvestre et al. 1999).

From the literature it is known that rolipram can have sedative side-effects at higher doses, shown by dose-dependent hypo activity in the open field task (Griebel et al. 1991; Silvestre et al. 1999). Since the object recognition performance can only be determined if the animals show sufficient exploration (Sik et al. 2003), we also evaluated the exploration levels of the animals. In our time-dependent experiment with untreated animals, a dose of $0.1 \mathrm{mg} / \mathrm{kg}$ rolipram, given $30 \mathrm{~min}$ before $\mathrm{T} 1$, resulted in a substantial decrease in exploratory activity. This finding may be indicative of a sedative effect at this dose. However, in the second experiment in which the animals were treated with scopolamine as well, no effects on exploratory behavior were observed at this dose. These findings are in line with previous studies that do not report behavioral side effects of even higher rolipram doses (> $0.1 \mathrm{mg} / \mathrm{kg}$ ) 
in combination with similar doses of scopolamine (Imanishi et al. 1997; Silvestre et al. 1999; Zhang and O'Donnell 2000). However, in our second experiment side effects were observed again at a dose of $0.3 \mathrm{mg} / \mathrm{kg}$ rolipram in the scopolamine model. Assuming that the side-effects are mediated by the neurotransmitter ACh, the cholinergic side-effects of this dose of rolipram are possibly no longer fully antagonized by scopolamine. Since the difference in doses between side effects and cognition enhancing effects of rolipram is only a factor three, this implies a steep dose-response curve for rolipram to affect neurotransmitter levels or activating PKA.

On the basis of the different dose-response curves of rolipram in both experiments, we assume that the effects of rolipram on memory performance might be mediated by two different processes. The first mechanism works via cAMP activated PKA, which plays a key role in the induction of L-LTP and long-lasting neuronal changes. The activation of the cAMPPKA system is specifically required at about $3 \mathrm{~h}$ after training. Thus during the process of late memory consolidation the CAMP-PKA pathway cascade is believed to trigger events, including the activation of transcription factors such as CREB (Friedrich et al. 2004).

The second mechanism by which rolipram could affect learning and memory is via its ability to influence different neurotransmitter systems. The effectiveness of rolipram is thought to be due to a stimulatory effect on cholinergic transmission by both enhancement of cholinergic turnover presynaptically and inhibition of cAMP degradation postsynaptically (Imanishi et al. 1997). Furthermore, elevated intracellular cAMP levels are thought to excite noradrenergic and dopaminergic (Schoffelmeer et al. 1985) neurotransmitter systems and thus increasing their availability, hence also enhancing synaptic transmission.

In summary, this study suggests that rolipram improves object recognition memory performance by two different mechanisms of action. Clearly, further neurochemical studies are required to support this notion.

\section{References}

Bach ME, Barad M, Son H, Zhuo M, Lu YF, Shih R, Mansuy I, Hawkins RD, Kandel ER (1999) Age-related defects in spatial memory are correlated with defects in the late phase of hippocampal long-term potentiation in vitro and are attenuated by drugs that enhance the cAMP signaling pathway. Proc. Natl. Acad. Sci. USA 96: 5280-5

Bailey CH, Bartsch D, Kandel ER (1996) Toward a molecular definition of long-term memory storage. Proc. Natl. Acad. Sci. USA 93: 13445-52

Barad M, Bourtchouladze R, Winder DG, Golan H, Kandel E (1998) Rolipram, a type IV-specific phosphodiesterase inhibitor, facilitates the establishment of long-lasting long-term potentiation and improves memory. Proc. Natl. Acad. Sci. USA 95: 15020-15025

Bernabeu R, Bevilaqua L, Ardenghi P, Bromberg E, Schmitz P, Bianchin M, Izquierdo I, Medina JH (1997) Involvement of hippocampal cAMP/cAMP-dependent protein kinase signaling pathways in a late memory consolidation phase of aversively motivated learning in rats. Proc. Natl. Acad. Sci. USA. 94: 7041-6

Bernabeu R, Schmitz P, Faillace MP, Izquierdo I, Medina JH (1996) Hippocampal cGMP and cAMP are differentially involved in memory processing of inhibitory avoidance learning. Neuroreport 7: 585-588

Bliss TV, Collingridge GL (1993) A synaptic model of memory: long-term potentiation in the hippocampus. Nature 361: 31-9 
Bourtchouladze R, Lidge R, Catapano R, Stanley J, Gossweiler S, Romashko D, Scott R, Tully T (2003) A mouse model of Rubinstein-Taybi syndrome: defective long-term memory is ameliorated by inhibitors of phosphodiesterase 4. Proc. Natl. Acad. Sci. U S A 100: 10518-22

Egawa T, Mishima K, Matsumoto Y, Iwasaki K, Fujiwara M (1997) Rolipram and its optical isomers, phosphodiesterase 4 inhibitors, attenuated the scopolamine-induced impairments of learning and memory in rats. Jpn. J. Pharmacol. 75: 275-281

Ennaceur A, Delacour J (1988) A new one-trial test for neurobiological studies of memory in rats. 1: Behavioral data. Behav. Brain Res. 31: 47-59

Frey U, Huang YY, Kandel ER (1993) Effects of cAMP simulate a late stage of LTP in hippocampal CA1 neurons. Science 260: 1661-4

Friedrich A, Thomas U, Muller U (2004) Learning at different satiation levels reveals parallel functions for the cAMP-protein kinase A cascade in formation of long-term memory. J. Neurosci. 24: 4460-8

Ghelardini C, GaleottiN, GualtieriF, RomanelliMN, BucherelliC, BaldiE, BartoliniA(2002)DM235 (sunifiram): a novel nootropic with potential as a cognitive enhancer. Naunyn Schmiedebergs Arch. Pharmacol. 365:419-26

Gong B, Vitolo OV, Trinchese F, Liu S, Shelanski M, Arancio O (2004) Persistent improvement in synaptic and cognitive functions in an Alzheimer mouse model after rolipram treatment. J. Clin. Invest. 114: 1624-1634

GriebelG, Misslin R, VogelE, BourguignonJJ (1991) Behavioral effects of rolipram and structurallyrelated compounds in mice: behavioral sedation of cAMP phosphodiesterase inhibitors. Pharmacol. Biochem. Behav. 39:321-3

Hammond RS, Tull LE, Stackman RW (2004) On the delay-dependent involvement of the hippocampus in object recognition memory. Neurobiol. Learn. Mem. 82: 26-34

Imanishi T, Sawa A, Ichimaru Y, Miyashiro M, Kato S, Yamamoto T, Ueki S (1997) Ameliorating effects of rolipram on experimentally induced impairments of learning and memory in rodents. Eur. J. Pharmacol. 321: 273-278

Impey S, Mark M, Villacres EC, Poser S, Chavkin C, Storm DR (1996) Induction of CRE-mediated gene expression by stimuli that generate long-lasting LTP in area CA1 of the hippocampus. Neuron 16: 973-82

Krause W, Kuhne G (1988) Pharmacokinetics of rolipram in the rhesus and cynomolgus monkeys, the rat and the rabbit. Studies on species differences. Xenobiotica 18: 561-71

Lu YF, Hawkins RD (2002) Ryanodine receptors contribute to cGMP-induced late-phase LTP and CREB phosphorylation in the hippocampus. J. Neurophysiol. 88: 1270-8

Lu YF, Kandel ER, Hawkins RD (1999) Nitric oxide signaling contributes to late-phase LTP and CREB phosphorylation in the hippocampus. J. Neurosci. 19: 10250-61

Nagakura A, Niimura M, Takeo S (2002) Effects of a phosphodiesterase IV inhibitor rolipram on microsphere embolism-induced defects in memory function and cerebral cyclic AMP signal transduction system in rats. Br. J. Pharmacol. 135: 1783-93

Prickaerts J, de Vente J, Honig W, Steinbusch HW, Blokland A (2002a) cGMP, but not cAMP, in rat hippocampus is involved in early stages of object memory consolidation. Eur. J. Pharmacol. 436: 83-87

Prickaerts J, Sik A, van der Staay FJ, de Vente J, Blokland A (2005) Dissociable effects of acetylcholinesterase inhibitors and phosphodiesterase type 5 inhibitors on object recognition memory: acquisition versus consolidation. Psychopharmacology 177: 381-390

Prickaerts J, Steinbusch HW, Smits JF, de Vente J (1997) Possible role of nitric oxide-cyclic GMP pathway in object recognition memory: effects of 7-nitroindazole and zaprinast. Eur. J. Pharmacol. 337: 125-136

Prickaerts J, van Staveren WC, Sik A, Markerink-van Ittersum M, Niewohner U, van der Staay FJ, Blokland A, de Vente J (2002b) Effects of two selective phosphodiesterase type 5 inhibitors, sildenafil and vardenafil, on object recognition memory and hippocampal cyclic GMP levels in the rat. Neuroscience 113: 351-361

Randt CT, Judge ME, Bonnet KA, Quartermain D (1982) Brain cyclic AMP and memory in mice. Pharmacol. Biochem. Behav. 17: 677-80

Schoffelmeer AN, Wardeh G, Mulder AH (1985) Cyclic AMP facilitates the electrically evoked release of radiolabelled noradrenaline, dopamine and 5-hydroxytryptamine from rat brain slices. Naunyn Schmiedebergs Arch. Pharmacol. 330: 74-6

Sik A, van Nieuwehuyzen P, Prickaerts J, Blokland A (2003) Performance of different mouse strains in an object recognition task. Behav. Brain. Res. 147: 49-54 
Silvestre JS, Fernandez AG, Palacios JM (1999) Preliminary evidence for an involvement of the cholinergic system in the sedative effects of rolipram in rats. Pharmacol. Biochem. Behav. 64: 1-5

Slack JR, Walsh C (1995) Effects of a cAMP analogue simulate the distinct components of long-term potentiation in CA1 region of rat hippocampus. Neurosci. Lett. 201: 25-8

Zhang HT, Crissman AM, Dorairaj NR, Chandler LJ, O'Donnell JM (2000) Inhibition of cyclic AMP phosphodiesterase (PDE4)reversesmemorydeficitsassociatedwithNMDAreceptorantagonism.Neuropsychopharm.23:198-204

Zhang HT, O'Donnell JM (2000) Effects of rolipram on scopolamine-induced impairment of working and reference memory in the radial-arm maze tests in rats. Psychopharm. 150: 311-316

Zhang HT, Zhao Y, Huang Y, Dorairaj NR, Chandler LJ, O'Donnell JM (2004) Inhibition of the phosphodiesterase 4 (PDE4) enzyme reverses memory deficits produced by infusion of the MEK inhibitor U0126 into the CA1 subregion of the rat hippocampus. Neuropsychopharm. 29: 1432-9 



\title{
TIME-DEPENDENT INVOLVEMENT OF CAMP AND CGMP IN CONSOLIDATION OF OBJECT MEMORY: STUDIES USING SELECTIVE PHOSPHODIESTERASE TYPE 2, 4 AND 5 INHIBITORS
}

K. Rutten, J. Prickaerts, M. Hendrix, F.j. Van Der Staay, A. Şik And A. Blokland

European Journal of Pharmacology (2007) 558: 107-112

\begin{abstract}
The present study investigated the time dependent memory enhancing properties of three selective phosphodiesterase inhibitors (PDE-I) vardenafil (PDE5-I), rolipram (PDE4-I) and BAY 60-7550 (PDE2-I) in the object recognition task. In particular, the time-dependent involvement of cAMP and cGMP in memory consolidation were assessed by altering the time points of drug administration. Vardenafil ( $1 \mathrm{mg} / \mathrm{kg}$, p.o.), rolipram (0.03 mg/kg, i.p.), and BAY 60-7550 (3 mg/kg, p.o.) were tested in rats with a $24 \mathrm{~h}$ delay between the learning and the test trial. The PDE-Is were administered at different time points, i.e. directly after, $1 \mathrm{~h}, 3 \mathrm{~h}$ and $6 \mathrm{~h}$ after the first trial. Using a $24 \mathrm{~h}$ interval, vardenafil only showed an effect on object memory when injected directly after trial 1, rolipram only showed an improvement when injected $3 \mathrm{~h}$ after trial1 and BAY 60-7550 improved memory when injected either directly after or $3 \mathrm{~h}$ after trial 1. No treatment effects were found when the compounds were administered 1h or $6 \mathrm{~h}$ after the first trial. Our results extend our previous data that different types of PDE-Is affect different stages of memory consolidation. Moreover, the present study provides further support that selective PDEIs can influence memory consolidation in a time dependant manner, assumingly by elevating central cAMP and cGMP levels.
\end{abstract}




\section{Introduction}

Recently, evidence has been accumulating that the second messenger molecules, cyclic GMP (cGMP) and cyclic AMP (cAMP) are differentially involved in learning and memory processes. In a one-trial learning paradigm intra-hippocampal infusions of 8-Br-cAMP directly after the first, i.e acquisition trial, did not improve memory performance in the second, i.e. retention trial. In contrast, infusions of 8-Br-cGMP directly after the first trial improved memory performance (Prickaerts et al. 2002a). Moreover, when 8-Br-cAMP was injected 3h after trial 1, memory enhancement was observed but for 8-Br-cGMP this was not the case (Bernabeu et al. 1997). These findings imply different temporal effects of cGMP and cAMP on memory. It has been suggested that inhibition of phosphodiesterases (PDEs), which selectively hydrolyze cyclic nucleotides, may be a reliable method to enhance memory performance (Prickaerts et al. 2004).

Eleven subclasses of PDEs have been identified so far, but hitherto only the PDE4, 5 and recently PDE2 have been demonstrated to be effective in memory enhancement (Blokland et al. 2006a). Selective PDE4 inhibitors (PDE4-I) selectively inhibit the hydrolysis of cAMP. Ample evidence suggests a role for the cAMP/PKA/CREB pathway in the cognition enhancing abilities of PDE4-I (Imanishi et al. 1997; Tully et al. 2003). In particular, the selective PDE4-I rolipram has been widely tested in cognition studies (for review see: Blokland et al. 2006a).

A recent study from our group showed memory enhancement after rolipram (selective PDE4-I) treatment in the object recognition task (Rutten et al. 2006a). This effect was found when rolipram was injected $3 \mathrm{~h}$, but not when it was injected directly after trial 1 , suggesting that the time of injection is of great importance in this respect.

PDE5 inhibitors (PDE5-I) such as sildenafil (Viagra ${ }^{\circledR}$ ) and vardenafil (Levitra ${ }^{\circledR}$ ) have not only been shown to be effective in the treatment of erectile dysfunction, but they are also candidate drugs for cognition enhancement. For instance, the specific PDE5-Is sildenafil and vardenafil have been shown to improve object recognition memory when injected immediately following the first trial (Prickaerts et al. 2002b). PDE5-Is are assumed to improve early processes of memory consolidation via either a presynaptic or a postsynaptic mechanism. The presynaptic mechanism acts through the Nitric Oxide (NO)-cGMP signalling pathway and the postsynaptic mechanism through the cGMP/ Protein Kinase G/cAMP Response Element Binding protein (cCMP/PKG/CREB) signalling pathway (Prickaerts et al. 2004).

Most recently another type of PDE-Is has been proposed for cognition enhancement, namely PDE 2 inhibitors (PDE2-I). PDE2 enzymes hydrolyze both cAMP and cGMP and therefore inhibition of PDE2 may selectively increase both cAMP and cGMP levels, which influence synaptic plasticity and memory formation. The novel selective PDE2 inhibitor 2-(3,4-dimethoxybenzyl)-7-\{(1R)-1-[(1R)-1-hydroxyethyl]-4-phenylbutyl\}-5-methyl imidazo[5,1-f][1,2,4]triazin-4(3H)-one (BAY 60-7550) revealed cognition enhancing properties in one-trial learning tests, such as social and object recognition (Boess et al. 2004). In this study it was shown that BAY 60-7550 was effective when injected directly after trial 1 . 
Since PDE5-Is also improve memory when injected after trial 1 in an object recognition task, it was assumed that the effects of PDE2 inhibition were mediated via cGMP.

In the present study we investigated the time-dependent involvement of cAMP and cGMP in memory consolidation by directly comparing the effects of three different types of PDE-Is: PDE5, PDE4 and PDE2. By altering the time of drug administration, the differential temporal effects of the PDE-Is vardenafil, rolipram and BAY 60-7550 were assessed.

\section{Materials and methods}

\section{Animals}

All experimental procedures were approved by the local ethical committee of the Maastricht University for animal experiments according to governmental guidelines. A total of 66 young adult male Wistar rats (Charles River, The Netherlands) were used in this study. The animals were divided into three experimental groups ( $\mathrm{n}=22$ /group) for behavioral drug testing. The animals were housed individually in standard type 3 Makrolon cages on sawdust bedding in an air-conditioned room (about $20^{\circ} \mathrm{C}$ ). They were kept under a reversed 12/12-hour light/dark cycle (lights on from 18.00 to $6.00 \mathrm{~h}$ ) and had free access to food and water. Rats were housed in the room where they were tested. A radio that played softly provided background noise in all rooms. All testing was done between 9.00 and $17.00 \mathrm{~h}$ under red light conditions.

\section{Object recognition memory}

The object recognition test was performed as described elsewhere (Ennaceur and Delacour 1988). The apparatus consisted of a circular arena, $83 \mathrm{~cm}$ in diameter. Half of the $40 \mathrm{~cm}$ high wall was made of grey polyvinyl chloride, the other half of transparent polyvinyl chloride. The light intensity (20 lux) was equal in the different parts of the apparatus. Two objects were placed in a symmetrical position about $10 \mathrm{~cm}$ away from the grey wall. We used four different sets of objects. The different objects were: 1) a cone consisting of a grey polyvinyl chloride base (maximal diameter $18 \mathrm{~cm}$ ) with a collar on top made of brass (total height 16 $\mathrm{cm}), 2$ ) a standard 11 transparent glass bottle (diameter $10 \mathrm{~cm}$, height $22 \mathrm{~cm}$ ) filled with sand, 3) a massive metal cube $(10.0 \times 5.0 \times 7.5 \mathrm{~cm})$ with two holes (diameter $1.9 \mathrm{~cm})$, and 4) a massive aluminium cube with a tapering top $(13.0 \times 8.0 \times 8.0 \mathrm{~cm})$. The objects could not be displaced by a rat.

In the first week, the animals were handled daily and were adapted to the observation arena on two successive days, i.e., they were allowed to explore the apparatus (without any objects) twice for $3 \mathrm{~min}$ each day. In the next two weeks the rats were adapted to the testing and intra peritoneal (i.p.) and oral (p.o.) administration procedures by a saline injection ( $0.4 \mathrm{ml})$ immediately after the first trial until they showed a stable discrimination performance, i.e., good object discrimination at a 1-h interval. Subsequently, testing of the drugs began. 
A testing session comprised two trials. The duration of each trial was 3 min. During the first trial the apparatus contained two identical objects (samples). A rat was always placed in the apparatus facing the wall in the centre of the transparent front segment. After the first exploration period the rat was put back in its home cage. Subsequently, after a delay interval, the rat was put back in the apparatus for the second trial, but now with two dissimilar objects, a familiar one (the sample) and a new one. The times spent exploring each object during the first and the second trial were recorded manually using a personal computer.

Exploration was defined as follows: directing the nose to the object at a distance of no more than $2 \mathrm{~cm}$ and/or touching the object with the nose. Sitting on the object was not considered exploratory behaviour. In order to avoid the presence of olfactory trails the objects were thoroughly cleaned after each trial. Moreover, each object was available in triplicate so none of the two objects from the first trial had to be used as the familiar object in the second trial. In addition, all combinations and locations of objects were used in a balanced manner to reduce potential biases due to preferences for particular locations or objects.

Since we expected the drug treatments to improve long term memory performance we needed a delay interval at which rats did not discriminate between the objects above chance level. Therefore, we selected a delay interval of $24 \mathrm{~h}$, since Wistar rats show no discrimination between the two objects after this interval (Prickaerts et al. 2002b). Each week two testing sessions were given, one session comprised Monday (trial 1) and Tuesday (trial 2) and the other one comprised Thursday (trial 1) and Friday (trial 2).

\section{Treatments}

All substances were dissolved in their vehicles and were administered at one of four time points per condition. The time points of administration for each substance were: immediately after the first trial , or $1 \mathrm{~h}, 3 \mathrm{~h}$, or $6 \mathrm{~h}$ after the first trial. The order of treatment conditions was randomly chosen. Each time point of administration was tested once in all 22 animals. Each of the three different PDE-Is was tested in a separate group of 22 animals.

The PDE5-I vardenafil was prepared daily and dissolved in $1 \%$ tylose (methylcellulose) and 99\% distilled water on every experimental day. The substance was tested at an optimal dose of $1 \mathrm{mg} / \mathrm{kg}$ (Prickaerts et al. 2002b), administered orally (p.o.) by means of a canule in an application volume of $2 \mathrm{ml} / \mathrm{kg}$.

The PDE4-I rolipram was freshly suspended in 5\% ethanol, 1\% tylose (methylcellulose) and $94 \%$ distilled water on every experimental day. Rolipram was tested at the dose of $0.03 \mathrm{mg} / \mathrm{kg}$. This is the most optimal dose for a memory enhancing effect when injected $3 \mathrm{~h}$ after the first trial (Rutten et al. 2006a). Rolipram was always administered i.p. in an application volume of $2 \mathrm{ml} / \mathrm{kg}$.

The PDE2-I Bay 60-7550 was prepared daily and dissolved in 10\% solutol, 5\% ethanol and 85\% distilled water. Bay 60-7550 was tested at a dose of $3 \mathrm{mg} / \mathrm{kg}$ because this dose was shown to be effective in the object recognition test when injected im- 
mediately after the first trial (Boess et al. 2004). The compound was administered p.o. in an injection volume of $5 \mathrm{ml} / \mathrm{kg}$.

\section{Statistical analysis}

The basic measures were the times spent by rats in exploring an object during trial 1 and trial 2. Table 1 shows the measures involved in the object recognition task (Prickaerts et al. 1997). $e 1$ and $e 2$ are measures of the total exploration time of both objects during trial 1 and trial 2 respectively. D2 was considered as index measure of discrimination between the new and the familiar objects. In fact, $d 2$ is a relative measure of discrimination which corrects the difference between exploring the old and the novel object for exploration activity (e2). Animals that did not explore sufficiently in the second trial (i.e. less than 5s) were excluded from the data analysis for that particular delay condition.

For all parameters the effects of the different administration time points (vehicle, directly after trial 1 vs. drug, directly after trial 1, or 1-, 3-, or 6-hours after trial 1) were analyzed with a one way ANOVA. Drug effects with respect to vehicle treatment were analyzed in more detail using the Bonferroni post hoc t-test.

Table 1. Measures involved in the object recognition test

\begin{tabular}{cc}
\hline Exploration & Discrimination \\
\hline$e 1=a 1+a 2$ & $d 2=b-a / e 2$ \\
$e 2=a+b$ & \\
\hline
\end{tabular}

$e 1$ is the measure of the time spent in exploring both identical objects ( $a 1$ and $a 2$ ) in T1,

$e 2$ is the measure of the time spent in exploring both the familiar ( $a$ ) and new object $(b)$ in T2;

$d 2$ is the measure of discrimination between the new and familiar objects.

\section{Results}

\section{PDE5 inhibition}

The results of treatment with the PDE5 inhibitor vardenafil on exploration times are shown in Table 2A. In the first trial differences in exploration times were observed between the different administration conditions $(e 1: \mathrm{F}(4,108)=5.83 ; P<0.01)$. Post-hoc analysis showed that the level of exploration for animals treated $3 \mathrm{~h}$ after trial 1 was higher than all other treatment conditions except when the animals were treated directly after trial 1.

Also, in the second trial there were differences between treatment conditions in the level of exploration $(e 2: \mathrm{F}(4,108)=5.35 ; P<0.01)$. The animals in the vehicle condition explored less than the animals treated with vardenafil one or three hours after the first trial.

Figure 1 (left panel) shows the time dependent effects of vardenafil treatment on object recognition performance. Differences between treatment conditions on the discrimi- 
nation index were observed $(d 2: \mathrm{F}(4,108)=3.00 ; P<0.05)$. Post-hoc analysis showed that vardenafil, administered directly the first trial improved the object recognition performance; whereas injection of vardenafil at other time points had no effect on recognition memory.

Table 2. Results of treatment with three different PDE inhibitors on the exploration measures (in s) of the object recognition test.

\begin{tabular}{|c|c|c|c|c|c|}
\hline & VEHICLE & DRUG & DRUG & DRUG & DRUG \\
\hline & $\mathrm{T} 1+0 \mathrm{~h}$ & $\mathrm{~T} 1+0 \mathrm{~h}$ & $\mathrm{~T} 1+1 \mathrm{~h}$ & $\mathrm{~T} 1+3 \mathrm{~h}$ & $T 1+6 h$ \\
\hline \multicolumn{6}{|c|}{ A) Vardenafil (PDE5 inhibitor) } \\
\hline el & $15.73(1.05)$ & $20.19(1.35)$ & $17.05(1.42)$ & $23.28(1.50) a$ & $15.90(1.44)$ \\
\hline e2 & $18.04(1.15)$ & $24.52(2.22)$ & $24.37(1.31) \mathrm{a}$ & $28.54(1.82) a$ & $22.82(1.65)$ \\
\hline \multicolumn{6}{|c|}{ B) Rolipram (PDE4 inhibitor) } \\
\hline el & $16.54(0.77)$ & $20.01(1.13)$ & $18.95(1.47)$ & $17.70(1.27)$ & $18.79(1.43)$ \\
\hline$e 2$ & $21.69(1.12)$ & $29.38(1.94) a$ & $20.43(1.72)$ & $24.79(1.24)$ & $27.39(1.76)$ \\
\hline \multicolumn{6}{|c|}{ C) BAY 60-7550 (PDE2 inhibitor) } \\
\hline el & $19.58(1.59)$ & $19.40(1.33)$ & $20.44(2.02)$ & $17.48(1.67)$ & $21.70(1.01)$ \\
\hline e2 & $20.93(1.76)$ & $18.40(1.65)$ & $27.64(1.93) a$ & $21.39(1.30)$ & $26.16(2.15) \mathrm{a}$ \\
\hline
\end{tabular}

Wistar rats ( $n=22$ per drug group) received drug administrations at different time points after T1. The delay between the first and the second interval was $24 \mathrm{~h}$. Entries are means ( \pm S.E.M.) (a depicts differences from vehicle, $P<0.05$ Bonferonni t-tests).

\section{PDE4 inhibition}

Effects of administering rolipram at different time points on the exploration times are presented in Table 2B. Exploration in the first trial was unaffected (e1: $\mathrm{F}(4,109)=1.14$; n.s.). However, differences in exploration time were observed in the second trial $(e 2: \mathrm{F}(4,109)=$ 5.60; $P<0.01$ ). Post-hoc analysis showed that the level of exploration was higher when the animals were injected with rolipram directly after the first trial than when the animals were treated with vehicle or with rolipram 1 h after the first trial. The effects of rolipram administered at different time points after the first trial on the memory performance are depicted in Figure 1 (center panel). A between treatment time points analysis of the $d 2$ values showed a time-dependent effect $(d 2: F(4,109)=2.80 ; P<0.05)$. Post-hoc comparisons between the different drug administration time points and the vehicle condition showed that only the animals treated $3 \mathrm{~h}$ after trial 1 discriminated between the novel and the familiar object.

\section{PDE2 inhibition}

The results of treatment with the PDE2 inhibitor, Bay 60-7550 on the exploration times are summarized in Table 2 (right panel). The total level of exploration during the first trial 

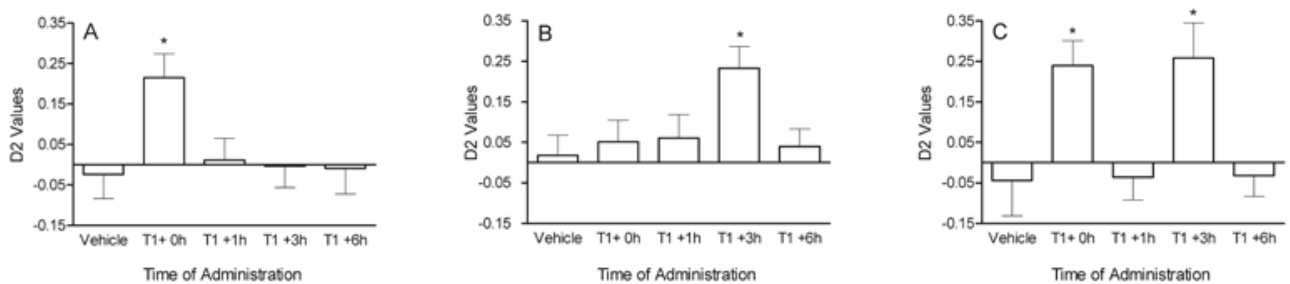

Figure 1: Effects of three PDE inhibitors on the discrimination performance in the object recognition task (means + S.E.M.). The delay between the learning trial (trial 1) and the test trial (trial 2) was $24 \mathrm{~h}$. Rats were treated with PDE inhibitors at four different points of administration after the first trial. The time points were directly after trial 1, $1 \mathrm{~h}$ after trial $1,3 \mathrm{~h}$ after trail 1 or $6 \mathrm{~h}$ after trial 1. (left panel) Treatment with the PDE5 inhibitor vardenafil (1 mg/kg), (center panel) Treatment with the PDE4 inhibitor rolipram $(0.03 \mathrm{mg} / \mathrm{kg})$ and (right panel) Treatment with the PDE2 inhibitor Bay 60-7550 (3 mg/kg). Differences from the vehicle condition are depicted as asterisks (Bonferroni t-test; $\left.{ }^{*} P<0.05\right)$.

was similar between sessions $(e 1: \mathrm{F}(4,106)=1.01$; n.s.). In the second trial there was a difference between the treatment conditions $(e 2: \mathrm{F}(4,106)=4.98 ; P<0.01)$. Post-hoc analysis showed that the level of exploration for the group that was administered directly after trial 1 was lower than the groups that were administered 1 h or $6 \mathrm{~h}$ after trial 1 . The results of Bay 60-7550 treatment on the $d 2$ index of object discrimination are depicted in Figure $1 C$. The $\mathrm{d} 2$ indices were affected by the different time points of drug administration $(\mathrm{F}(4,106)=$ 4.91; $P<0.01$ ). Post-hoc analysis revealed that the $d 2$ values were higher than those of the vehicle condition, when the rats were injected with the PDE2-I directly after, or 3 h after trial 1 , but not when injected 1 h or 6 h after trial 1.

\section{Discussion}

In the present study we found that PDE2-, 4- and 5 inhibitors can reverse the timedependent forgetting in the object recognition test in rats. However, the efficacy of the different PDE-Is appeared to depend on the time point of administration after acquisition (trial 1).

When injected with vehicle, all three groups of Wistar rats had no memory of the familiar object in the second trial. In a previous time-dependent study with rolipram, we found that the dose of $0.03 \mathrm{mg} / \mathrm{kg}$ was the optimal dose in the object recognition task, when injected $3 \mathrm{~h}$ after the first trial (Rutten et al. 2006a). The present study confirmed this earlier finding. When rolipram was injected directly after, 1 h or $6 \mathrm{~h}$ after trial 1 , no memory enhancement was observed. As expected, a dose of $1 \mathrm{mg} / \mathrm{kg}$ vardenafil administered directly after the first trial improved memory, corroborating our earlier findings (Prickaerts et al. 2002b). However, when vardenafil was administered at a later time point after training (i.e. 1h, 3h, or 6 h after trial 1) no memory enhancing effects were observed. Finally, we examined the effects of the selective PDE2-I BAY 60-7550 in the object recognition task. A previous study showed that the effective dose when injected directly after the first trial 
was $3 \mathrm{mg} / \mathrm{kg}$ (Boess et al. 2004). The present study corroborates these findings and shows that this PDE2-I is also active when injected 3 h after trial 1. Surprisingly, when BAY 60-7550 was injected 1 h after trial 1 or $6 \mathrm{~h}$ after trial 1 no effects on object recognition memory were found. These findings may be explained by the underlying mechanisms of action and the pharmacokinetics of these different drugs.

\section{PDE5 inhibition}

There is ample evidence that cGMP and cAMP are differentially involved in the memory consolidation processes (Prickaerts et al. 2004). Several studies have found memory enhancing effects of PDE5-Is when injected before or directly after training (e.g. Campbell and Edwards 2006; Devan et al. 2006; Devan et al. 2004; Prickaerts et al. 2005; Prickaerts et al. 1997; Rutten et al. 2005). Initially, cGMP was thought to act mainly pre-synaptically in the early phase of long term potentiation, via the NO/sGC/cGMP pathway. This form of long term potentiation lasts less than $3 \mathrm{~h}$ and requires no gene transcription or protein synthesis. Alternatively, the cGMP/PKG pathway has repeatedly been proposed as the underlying mechanism of action for early memory consolidation (Izquierdo and Medina 1997; Prickaerts et al. 2002b; Zhuo et al. 1994). Recently, it has been shown that the cGMP/PKG/CREB pathway is also involved in late phase long term potentiation, which lasts longer than $3 \mathrm{~h}$ (Lu and Hawkins 2002; Lu et al. 1999). This pathway may also be involved in early consolidation processes and may thus be mediated by sustained elevated cGMP levels in the object recognition task, i.e. cGMP is only effective when administered immediately after one-trial learning (Bernabeu et al. 1997; Prickaerts et al. 2002a). At present, it is unclear which pathway is underlying the memory enhancing effects of selective PDE5 inhibition. Studies are underway to localize the PDE5 enzyme at the subcellular level.

No data are currently available about the half-life of vardenafil in rats. Since in humans vardenafil and sildenafil have similar half lives (approximately $4 \mathrm{~h}$ ), after oral administration (Corbin and Francis 2002), it is assumed that half lives of these two compounds are similar in rats. Considering the short half life of sildenafil, approximately $0.4 \mathrm{~h}$ in male rats (Walker et al. 1999) we speculate that the time window for modulating the early consolidation processes via cGMP is narrow (between 0 and 1 h). When vardenafil was injected directly after learning memory enhancement was observed, but when the injection was delayed (1, 3, or 6h) memory was not affected, which is in agreement with the active time window of cGMP.

\section{PDE4 inhibition}

The data of rolipram are assumed to be related to elevated cAMP levels (Barad et al. 1998). cAMP is involved in late phase long term potentiation via the CAMP/PKA/CREB pathway (Bailey et al. 1996; Frey et al. 1993; Impey et al. 1996). Furthermore, it has been suggested 
that specifically late consolidation processes are affected by cAMP at $3 \mathrm{~h}$ after acquisition (Bernabeu et al. 1997; Prickaerts et al. 2002a). The findings of the present study support this notion. The half life of i.p. injected rolipram is approximately 1-3h (Krause and Kuhne 1988) and since rolipram has no effect on memory when injected earlier than the 3h time point (immediately after or $1 \mathrm{~h}$ after the first trial) or later than $3 \mathrm{~h}$ (i.e. $6 \mathrm{~h}$ ), the time window of rolipram for influencing the late consolidation processes of memory is quite specific, as is also the case for the active time window of cAMP.

\section{PDE2 inhibition}

In vitro studies have shown that BAY 60-7550 increased both cGMP and cAMP levels in hippocampal slices (Boess et al. 2004). We found an effect of BAY 60-7550 on object memory when it was given directly after training. This might be related to elevated cGMP levels, as the effect was observed at a drug administration time point where vardenafil affected recognition memory. In addition, improved object memory was observed when the PDE2-I was injected $3 \mathrm{~h}$ after training. Similar to the results of the rolipram study, these effects might be mediated by the elevation of cAMP levels and the process of late consolidation. When the short elimination half life of approximately 45 min after p.o. injection of BAY 60-7550 in rats (unpublished data) is taken into account, it appears once again that time windows for influencing early consolidation processes, possibly via cGMP and late consolidation processes, possibly through cAMP, are specific and narrow. The results from the experiment with this PDE2-I support the notion of a specific and time-critical role of cGMP and cAMP in memory consolidation and are consistent with the results obtained after treatment with rolipram or vardenafil.

Most probably, the dissociable effects of the three different classes of PDE-Is are not due to differences in pharmacokinetics, but to differences in the underlying mechanisms of action. All three PDE-Is have a relatively low half-life. This ensures that they affect processes during a restricted time window after drug administration and enables investigation of time-critical processes during the consolidation process. We believe that PDE5 inhibition (i.e. elevated cGMP levels) has an effect on early consolidation processes either pre-synaptically (through the cGMP/NO/sGC pathway) or post-synaptically (through the cGMP/PKG/CREB pathway). PDE4 inhibition generates its effects through elevated cAMP levels and the late consolidation processes of CAMP/PKA/CREB. PDE2-Is exert their effect both via cGMP and cAMP. This explains why the PDE2 inhibitor is effective when injected directly after (early consolidation) and $3 \mathrm{~h}$ after (late consolidation) the first trial. In addition, studies with intra-hippocampal infusions of cAMP and cGMP analogues have shown comparable behavioral effects (Bernabeu et al. 1997; Bernabeu et al. 1996; Prickaerts et al. 2002a) and underscore the notion that these intracellular second messengers have a time dependent role in memory consolidation. 


\section{Conclusions}

Summarizing, the timing of treatment modulates the effects on memory and strongly supports a role for cGMP in early stages of memory formation whereas for cAMP a role in the late stages of memory formation is presumed. Our study of time dependent administration of three different PDE-Is advocates specific roles of cAMP and cGMP in the long term memory consolidation processes within narrow time windows. Further, our data suggest that different types of PDE-Is can affect different stages of memory consolidation.

\section{References}

Bailey CH, Bartsch D, Kandel ER (1996) Toward a molecular definition of long-term memory storage. Proc. Natl. Acad. Sci. USA 93: 13445-52

Barad M, Bourtchouladze R, Winder DG, Golan H, Kandel E (1998) Rolipram, a type IV-specific phosphodiesterase inhibitor, facilitates the establishment of long-lasting long-term potentiation and improves memory. Proc. Natl. Acad. Sci. USA 95: 15020-15025

Bernabeu R, Bevilaqua L, Ardenghi P, Bromberg E, Schmitz P, Bianchin M, Izquierdo I, Medina JH (1997) Involvement of hippocampal cAMP/cAMP-dependent protein kinase signaling pathways in a late memory consolidation phase of aversively motivated learning in rats. Proc. Natl. Acad. Sci. USA 94: 7041-6

Bernabeu R, Schmitz P, Faillace MP, Izquierdo I, Medina JH (1996) Hippocampal cGMP and cAMP are differentially involved in memory processing of inhibitory avoidance learning. Neuroreport 7: 585-588

Blokland A, Schreiber R, Prickaerts J (2006) Improving Memory: A role for Phosphodiesterases. Curr. Pharm. Des. 12: 2511-2523

Boess FG, Hendrix M, van der Staay FJ, Erb C, Schreiber R, van Staveren W, de Vente J, Prickaerts J, Blokland A, Koenig G (2004) Inhibition of phosphodiesterase 2 increases neuronal cGMP, synaptic plasticity and memory performance. Neuropharmacology 47: 1081-92

Campbell E, Edwards T (2006) Zaprinast consolidates long-term memory when administered to neonate chicks trained using a weakly reinforced single trial passive avoidance task. Behav. Brain. Res. 169: 181-5

Corbin JD, Francis SH (2002) Pharmacology of phosphodiesterase-5 inhibitors. Int. J. Clin. Pract. 56: 453-9

Devan BD, Bowker JL, Duffy KB, Bharati IS, Jimenez M, Sierra-Mercado D, Jr., Nelson CM, Spangler EL, Ingram DK (2006) Phosphodiesterase inhibition by sildenafil citrate attenuates a maze learning impairment in rats induced by nitric oxide synthase inhibition. Psychopharmacology (Berl) 183: 439-45

Devan BD, Sierra-Mercado D, Jr., Jimenez M, Bowker JL, Duffy KB, Spangler EL, Ingram DK (2004) Phosphodiesterase inhibition by sildenafil citrate attenuates the learning impairment induced by blockade of cholinergic muscarinic receptors in rats. Pharmacol. Biochem. Behav. 79: 691-9

Ennaceur A, Delacour J (1988) A new one-trial test for neurobiological studies of memory in rats. 1: Behavioral data. Behav. Brain Res. 31: 47-59

Frey U, Huang YY, Kandel ER (1993) Effects of cAMP simulate a late stage of LTP in hippocampal CA1 neurons. Science 260: 1661-4

Imanishi T, Sawa A, Ichimaru Y, Miyashiro M, Kato S, Yamamoto T, Ueki S (1997) Ameliorating effects of rolipram on experimentally induced impairments of learning and memory in rodents. Eur. J. Pharmacol. 321: 273-278

Impey S, Mark M, Villacres EC, Poser S, Chavkin C, Storm DR (1996) Induction of CRE-mediated gene expression by stimuli that generate long-lasting LTP in area CA1 of the hippocampus. Neuron 16: 973-82

Izquierdo I, Medina JH (1997) Memory formation: the sequence of biochemical events in the hippocampus and its connection to activity in other brain structures. Neurobiol. Learn. Mem. 68: 285-316

Krause W, Kuhne G (1988) Pharmacokinetics of rolipram in the rhesus and cynomolgus monkeys, the rat and the rabbit. Studies on species differences. Xenobiotica 18: 561-71 
Lu YF, Hawkins RD (2002) Ryanodine receptors contribute to cGMP-induced late-phase LTP and CREB phosphorylation in the hippocampus. J. Neurophysiol. 88: 1270-8

Lu YF, Kandel ER, Hawkins RD (1999) Nitric oxide signaling contributes to late-phase LTP and CREB phosphorylation in the hippocampus. J. Neurosci. 19: 10250-61

Prickaerts J, de Vente J, Honig W, Steinbusch HW, Blokland A (2002a) cGMP, but not cAMP, in rat hippocampus is involved in early stages of object memory consolidation. Eur. J. Pharmacol. 436: 83-87

Prickaerts J, Sik A, van der Staay FJ, de Vente J, Blokland A (2005) Dissociable effects of acetylcholinesterase inhibitors and phosphodiesterase type 5 inhibitors on object recognition memory: acquisition versus consolidation. Psychopharmacology (Berl) 177: 381-390

Prickaerts J, Sik A, van Staveren WC, Koopmans G, Steinbusch HW, van der Staay FJ, de Vente J, Blokland A (2004) Phosphodiesterase type 5 inhibition improves early memory consolidation of object information. Neurochem. Int. 45: 915-928

Prickaerts J, Steinbusch HW, Smits JF, de Vente J (1997) Possible role of nitric oxide-cyclic GMP pathway in object recognition memory: effects of 7-nitroindazole and zaprinast. Eur. J. Pharmacol. 337: 125-136

Prickaerts J, van Staveren WC, Sik A, Markerink-van Ittersum M, Niewohner U, van der Staay FJ, Blokland A, de Vente J (2002b) Effects of two selective phosphodiesterase type 5 inhibitors, sildenafil and vardenafil, on object recognition memory and hippocampal cyclic GMP levels in the rat. Neuroscience 113: 351-361

Rutten K, Prickaerts J, Blokland A (2006) Rolipram reverses scopolamine-induced and time-dependent memory deficits in object recognition by different mechanisms of action. Neurobiol. Learn. Mem. 85: 132-8

Rutten K, Vente JD, Sik A, Ittersum MM, Prickaerts J, Blokland A (2005) The selective PDE5 inhibitor, sildenafil, improves object memory in Swiss mice and increases cGMP levels in hippocampal slices. Behav. Brain. Res. 164: 11-6

Tully T, Bourtchouladze R, Scott R, Tallman J (2003) Targeting the CREB pathway for memory enhancers. Nat. Rev. Drug. Discov. 2: 267-277

Walker DK, Ackland MJ, James GC, Muirhead GJ, Rance DJ, Wastall P, Wright PA (1999) Pharmacokinetics and metabolism of sildenafil in mouse, rat, rabbit, dog and man. Xenobiotica 29: 297-310

Zhuo M, Hu Y, Schultz C, Kandel ER, Hawkins RD (1994) Role of guanylyl cyclase and cGMP-dependent protein kinase in long-term potentiation. Nature 368: 635-9 



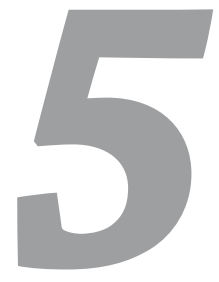

THE PDE4 INHIBITOR ROLIPRAM REVERSES OBJECT MEMORY IMPAIRMENT INDUCED BY ACUTE TRYPTOPHAN DEPLETION IN THE RAT

\author{
K. Rutten, C. Lieben, L. Smits, A. Blokland
}

Psychopharmacology (2007) in press

Rationale: The selective type IV phosphodiesterase (PDE) inhibitor, rolipram, has been shown to improve long-term memory and can reverse the cholinergic deficit caused by scopolamine. However underlying mechanisms of action of rolipram remain obscure. OBJECTIVES: The present study investigates the effect of rolipram in a serotonergic deficit model of acute tryptophan depletion (ATD). In addition, the levels of plasma tryptophan (TRP) were compared to object recognition performance. Materials and methods: The experiments were conducted using male Wistar rats. The time dependent effect of ATD treatment (a gelatin based protein mixture) on plasma TRP levels ( $0,1,3$ and $6 \mathrm{~h}$ after injection) and object recognition (ORT) performance $(0.5,1,3$ and $6 \mathrm{~h}$ after ATD treatment) was examined. The effect of rolipram (0, 0.01, 0.03 and $0.1 \mathrm{mg} / \mathrm{kg}$, i.p.) was tested in the condition in which ATD induced a clear memory deficit. Results: ATD significantly lowered the plasma TRP ratio (TRP/ LLNAA) with a maximum of 48\%, approximately $1 \mathrm{~h}$ after administration. Furthermore ATD impairs ORT performance when administered $3 \mathrm{~h}$ before testing. Rolipram $(0.1 \mathrm{mg} / \mathrm{kg})$ reversed the memory deficit induced by ATD in a dose dependent manner. Conclusions: On basis of previous studies and the ability to reverse a serotonergic deficit we suggest that rolipram may act through elevation of cAMP levels and subsequent increase in neurotransmitter release. 


\section{Introduction}

Inhibition of phosphodiesterase type 4 (PDE4) leads to an increase in intracellular cyclic adenosine monophosphate (cAMP) availability (Silvestre et al. 1999). cAMP is an important second messenger molecule in the process of intracellular signal transduction mechanisms (Bailey et al. 1996). Several studies have shown that rolipram, a selective PDE4 inhibitor, improves cognitive performance in young rats (Blokland et al. 2006a; Imanishi et al. 1997; Rose et al. 2005; Zhang et al. 2000; Zhang et al. 2004) and ameliorates scopolamine-induced memory deficits (Egawa et al. 1997; Imanishi et al. 1997; Rutten et al. 2006a; Zhang and O’Donnell 2000).

In a previous study we have shown that rolipram reversed a scopolamine-induced deficit in an object recognition task in male Wistar rats (Rutten et al. 2006a). It was suggested that these effects may be related to the effects of elevated cAMP levels on neurotransmitter release. There is also evidence that there is a link between PDE4 inhibition and serotonergic neurotransmission (Schoffelmeer et al. 1985; West and Galloway 1996). The adenylate cyclase activator forskolin as well as 8-bromo-cyclic AMP can enhance the electrically evoked release of 3H-5-hydroxytryptamine (Schoffelmeer et al. 1985). Thus elevating cAMP levels by a selective PDE4 inhibitor could exert a general facilitatory effect on 5-HT release. Based on these findings we argued that rolipram may also reverse memory deficits induced by a lowered 5-HT neurotransmission.

Acute tryptophan depletion (ATD) is a well established model to assess the role of serotonin in cognitive and affective functioning (Booij et al. 2003). The neurotransmitter serotonin is synthesized from its amino acid precursor tryptophan (TRP), which is obtained from our food. Free TRP is transported into the brain across the blood-brain barrier but has to compete for entrance with five other large neutral amino acids (LNAAs: valine, leucine, isoleucine, phenylalanine, and tyrosine). The ratio of TRP and these other LNAAs (TRP/ ILNAA ratio) is thought to be a more sensitive index of brain TRP availability (Fernstrom 1981; Wurtman et al. 1980). Since 5-HT is synthesized from TRP, through the rate limiting enzyme TRP-hydroxylase, the availability of TRP in the brain determines the amount of central 5-HT (Wurtman et al. 1980). Due to its reversible and non-intrusive effects, the method of ATD can be repeatedly used in animals and humans.

In humans acute tryptophan depletion (ATD) has a negative effect on memory consolidation (Park et al. 1994; Riedel et al. 1999; Schmitt et al. 2000). Furthermore, memory impairments in the object recognition task (ORT) have been observed in rats after ATD (Lieben et al. 2005b; Lieben et al. 2004b). Therefore, we hypothesized that rolipram could reverse an ATD induced memory deficit in rats by elevating 5-HT release in the brain. 
In addition to this aim of the study, we further examined the relation between peripheral TRP and memory performance. We investigated the effects of different pretreatment times of the TRP depleted mixture on object recognition memory. These data should provide more experimental support for a relation between plasma TRP, and consequently central 5-HT, and memory performance.

\section{Methods}

\section{Animals}

All experimental procedures were approved by the local ethical committee of the Maastricht University for animal experiments according to governmental guidelines. A total of forty-two 4-month-old male Wistar rats (Charles River, The Netherlands) were used (410-450 g). Rats were randomly assigned to either the biochemistry $(n=18)$ or the behavior group $(n=24)$. In the biochemistry groups the animals were randomly subdivided over three treatment groups, i.e. saline, TRP+, or TRP- ( $\mathrm{n}=6$ /group). The animals were housed individually in standard type 3 Makrolon cages on sawdust bedding in an air-conditioned room (about $20^{\circ} \mathrm{C}$ ). They were kept under a reversed 12/12-hour light/dark cycle (lights on from 18.00 to $6.00 \mathrm{~h}$ ) and had free access water. Rats were housed in the same room as where they were tested. A radio, that played softly, provided background noise in all rooms. All testing was done between 9.00 and $17.00 \mathrm{~h}$.

\section{Drugs and chemicals}

The Gelatin hydrolysate (Solugel C) was obtained from PB Gelatins (Tessenderlo, Belgium). Glucodry 210 was obtained from the Amylumgroup (Koog aan de Zaan, The Netherlands). L-tryptophan and rolipram was obtained from Sigma-Aldrich (Zwijndrecht, The Netherlands). Kaliumchloride $(\mathrm{KCl})$, calciumchloride-dihydrate $\left(\mathrm{CaCl}_{2} \cdot 2 \mathrm{H}_{2} \mathrm{O}\right)$ and 5-sulfosalicylic acid dihydrate were purchased from Merck (Darmstadt, Germany).

\section{Treatment}

During a period of two weeks preceding the experiment, the rats were handled and habituated to oral injections with normal tap water $(10 \mathrm{ml} / \mathrm{kg})$. On experimental days, the rats were fasted $14 \mathrm{~h}$ prior treatment until the testing period was completed. This was done to minimize the availability of TRP from food which would counteract the effects of the ATD treatment. The rats were orally treated with a protein-carbohydrate mixture containing TRP (TRP + group; in which $0.28 \% \mathrm{TRP}$ of the total protein was added to the mixture) or one lacking TRP (TRP- group; no TRP added to the mixture), or with saline. The composition of the nutritional mixture is shown in Table 1. 
In every experiment, each dose contained $4.0 \mathrm{~g}$ Solugel C/kg and $2.0 \mathrm{~g}$ Glucodry $/ \mathrm{kg}$ of the body weight and was given in a volume of $10 \mathrm{ml} / \mathrm{kg}$ between 8.30 and $12.30 \mathrm{~h}$. Blood samples were taken at baseline (20 min before treatment) and $60 \mathrm{~min}, 180 \mathrm{~min}$, and 360 min after the first treatment. For the behavioral studies in the object recognition task, the mixture was administered at different time points (see below).

Rolipram was freshly suspended in 5\% ethanol, 1\% tylose (methyl-cellulose) and 94\% distilled water on every experimental day. The following doses of rolipram were tested 0 , $0.01,0.03$ or $0.1 \mathrm{mg} / \mathrm{kg}$ always in combination with the TRP- mixture (3h before T1). Rolipram was always administered $30 \mathrm{~min}$ before T1 (i.p., injection volume $2 \mathrm{ml} / \mathrm{kg}$ ).

Table 1: Composition of mixture and determination of the amino acids in gelatin-based protein (mol).

\begin{tabular}{|c|c|}
\hline Protein (Solugel) in $100 \mathrm{ml}$ water & $100 \mathrm{~g}$ \\
\hline Aspartic acid & 4.8 \\
\hline Glutamic acid & 10.3 \\
\hline Hydroxyproline & 11.4 \\
\hline Serine & 3.4 \\
\hline Glycine & 23.2 \\
\hline Histidine & 0.8 \\
\hline Arginine & 10.0 \\
\hline Threonine & 2.0 \\
\hline Alanine & 10.4 \\
\hline Proline & 12.0 \\
\hline Tyrosine & 0.4 \\
\hline Valine & 2.2 \\
\hline Methionine & 0.7 \\
\hline Isoleucine & 1.0 \\
\hline Leucine & 2.5 \\
\hline Hydroxylysine & 0.9 \\
\hline Phenylalanine & 1.1 \\
\hline Lysine & 2.9 \\
\hline Carbohydrate (Glucodry 210) in $80 \mathrm{ml}$ water & 50.0 \\
\hline $\mathrm{KCl}$ & 0.094 \\
\hline $\mathrm{CaCl} 2.2 \mathrm{H} 2 \mathrm{O}$ & 2.32 \\
\hline L-tryptophan (TRP- group) & 0 \\
\hline L-tryptophan (TRP+ group) & 0.28 \\
\hline
\end{tabular}

The composition of the mixture $(\mathrm{g})$ used in this experiment is described in bold. The aminoacid spectrum (\%) of the Solugel protein was obtained from PB Gelatins, Tessenderlo, Belgium. 


\section{Biochemistry}

For the determination of plasma amino acid levels blood samples were taken at resting values and repeated at several points in time. Blood sampling was done via a tail-incision method (Fluttert et al. 2000). Promptly after collection of blood in sodium heparin tubes (Microvette ${ }^{\circledR}$ CB 300, Sarstedt, Germany), the samples were kept on ice. After centrifugation of the blood samples (at $4^{\circ} \mathrm{C}$ for $15 \mathrm{~min}$ at $3000 \mathrm{~g}$ in a Hettich EBA 12 centrifuge), plasma was deproteinised with cups containing dry 5 -sulfosalicylic acid ( $6 \mathrm{mg} / 100 \mu \mathrm{l}$ plasma) and the protein was spun down. Samples were frozen in liquid nitrogen and stored at $-80^{\circ} \mathrm{C}$. Before analysis, samples were thawed at $4^{\circ} \mathrm{C}$, vortex-mixed vigorously and centrifuged at 50,000 g in a Hereaus Model Biogufe Stratos for $10 \mathrm{~min}$ at $4^{\circ} \mathrm{C}$. From the clear supernatant $20 \mu \mathrm{l}$ was mixed with $1960 \mu \mathrm{l}$ water and $20 \mu \mathrm{l}$ norvaline and stored in the cooled $\left(7^{\circ} \mathrm{C}\right)$ sample compartment until analysis.

In addition to total plasma TRP, the concentrations of several other amino acids were determined with a fully automated high-performance liquid chromatrography (HPLC) system after precolumn derivatization with ophthaldialdehyde (OPA) (Van Eijk et al. 1993). OPA-AA derivates were quantified with fluorescence detection. The concentrations of the total plasma amino acids were expressed as $\mu \mathrm{mol} / \mathrm{l}$.

\section{Object recognition memory}

The object recognition test was performed as described elsewhere (Prickaerts et al. 2002a). The apparatus consisted of a circular arena, $83 \mathrm{~cm}$ in diameter. Half of the $40 \mathrm{~cm}$ high wall was made of grey polyvinyl chloride, the other half of transparent polyvinyl chloride. A light bulb was switched on during testing only and provided a light intensity (20 lux) which was equal in the different parts of the apparatus. Two objects were placed in a symmetrical position about $10 \mathrm{~cm}$ away from the grey wall. We used four different sets of objects. The different objects were: 1) a cone consisting of a grey polyvinyl chloride base (maximal diameter $18 \mathrm{~cm}$ ) with a collar on top made of brass (total height $16 \mathrm{~cm}$ ), 2) a standard 11 transparent glass bottle (diameter $10 \mathrm{~cm}$, height $22 \mathrm{~cm}$ ) filled with sand, 3) a massive metal cube $(10.0 \times 5.0 \times 7.5 \mathrm{~cm})$ with two holes (diameter $1.9 \mathrm{~cm})$, and 4$)$ a massive aluminum cube with a tapering top $(13.0 \times 8.0 \times 8.0 \mathrm{~cm})$. The objects could not be displaced by a rat.

In the first week, the animals were handled daily and were adapted to the procedure in two days, i.e., they were allowed to explore the apparatus (without any objects) twice for 3 min each day. In the two following weeks the rats were adapted to the testing and i.p. administration procedure by a saline injection $(0.4 \mathrm{ml}) 30 \mathrm{~min}$ before the first trial until they showed a stable discrimination performance, i.e., good object discrimination (a d2 value of about 0.30 , see below) at a $1 \mathrm{~h}$ interval on two successive sessions. Subsequently, testing of the drugs began. 
A testing session comprised two trials. The duration of each trial was 3 min. During the first trial (T1) the apparatus contained two identical objects (samples). A rat was always placed in the apparatus facing the wall in the centre of the transparent front segment. After the first exploration period the rat was put back in its home cage. Subsequently, after a delay interval, the rat was put back in the apparatus for the second trial (T2), but now with two dissimilar objects, a familiar one (the sample) and a new one. The times spent exploring each object during T1 and T2 were recorded manually with a personal computer.

Exploration was defined as follows: directing the nose to the object at a distance of no more than $2 \mathrm{~cm}$ and/or touching the object with the nose. Sitting on the object was not considered exploratory behavior. In order to avoid the presence of olfactory trails the objects were always thoroughly cleaned with alcohol (70\%). Moreover, each object was available in triplicate so neither of the two objects from the first trial had to be used as the familiar object in the second trial. In addition, all combinations and locations of objects were used in a balanced manner to reduce potential biases due to preferences for particular locations or objects.

Since we expected ATD to impair memory performance we needed a delay interval at which normal rats discriminate between the novel and familiar object. Therefore, we selected a delay interval of $1 \mathrm{~h}$, since Wistar rats show good discrimination between the two objects after this interval (Rutten et al. 2006a). Furthermore we hypothesized that rolipram may reverse deficits induced by ATD in a 1 h delay ORT. In one week three testing sessions were given with a $48 \mathrm{~h}$ washout period in between. Tests were always conducted on Mondays, Wednesdays and Fridays.

In the first behavioral experiment we investigated the effects of administration with TRP+ or TRP- mixture at different time points (i.e. $30 \mathrm{~min}, 1 \mathrm{~h}, 3 \mathrm{~h}$ or $6 \mathrm{~h}$ ) before testing in the ORT. Each rat always participated in each condition and the order of test conditions was decided at random.

The second behavioral experiment examined the effect of rolipram (30 min before T1) on object recognition performance in combination with the TRP- mixture at the most effective time-point (i.e. $3 \mathrm{~h}$ before T1). Thus, 5 treatment conditions were tested, i.e. saline, vehicle and TRP-, rolipram $0.01 \mathrm{mg} / \mathrm{kg}$ and TRP-, rolipram $0.03 \mathrm{mg} / \mathrm{kg}$ and TRP-, and rolipram $0.1 \mathrm{mg} / \mathrm{kg}$ and TRP-. Each rat was tested in each condition and the order of treatment conditions was decided at random. The same animals $(n=24)$ were used for both behavioral experiments, thus control conditions (TRP+) from experiment 1 can and saline from experiment 2 can be compared to each other. 


\section{Statistical analysis}

\section{Biochemistry}

The mean concentrations of plasma amino acids were determined for each treatment and time condition separately. The extent of reduction (expressed in absolute values and in percentage decline from resting values) was calculated for total plasma TRP concentrations and for the TRP/ $\Sigma$ LNAA ratio. Extreme values, as determined by an extremity test (see Dixon 1959), were excluded from statistical analysis. Differences in plasma amino acid concentrations were analyzed with GLM, with main factor 'treatment' and repeated measure factor 'time'. Separate one way analyses of variance (ANOVA) were performed to analyze differences between treatment conditions per time point. A post-hoc Bonferroni test was used to further characterize the differences between treatment conditions. Differences were regarded as statistically significant if $\mathrm{p}<0.05$.

\section{Behavior}

The basic measures were the times spent by rats exploring an object during T1 and T2. Table 2 shows the measures involved in the object recognition task (Prickaerts et al. 1997). el and $e 2$ are measures of the total exploration time of both objects during $\mathrm{T} 1$ and $\mathrm{T} 2$ respectively. $d 2$ was considered as index measures of discrimination between the new and the familiar objects. $d 2$ is a relative measure of discrimination which corrects the difference between exploring the old and the novel object for exploration activity (e2), and appears to be independent of the total exploration times (see Sik et al. 2003). In the object recognition task, results are not reliable if an animal explores both objects in the second trial for less than $5 \mathrm{~s}$ (Sik et al. 2003). Therefore in every session, animals that explored less than $5 \mathrm{~s}$ in the second trial (i.e. $e 2<5$ ) were excluded from analysis. For all parameters the effects of the different treatment, time and interactions were analyzed with univariate ANOVA for the first experiment and one-way ANOVA for the second experiment. Significant effects were analyzed in more detail using the Bonferroni correction. To compare control conditions, i.e the TRP+ (3h before the first trial) condition of the first experiment with the saline condition of the second experiment a t-test was performed. Differences were regarded as statistically significant if $p<0.05$.

Table 2. Measures involved in the object recognition test. $\mathrm{e} 1$ is the measure of the time spent in exploring both identical objects ( $a 1$ and $a 2$ ) in T1, $e 2$ is the measure of the time spent in exploring both the familiar (a) and new object (b) in T2; $d 2$ is the measure of discrimination between the new and familiar objects.

\begin{tabular}{cc}
\hline Exploration & Discrimination \\
\hline$e 1=a 1+a 2$ & $d 2=b-a / e 2$ \\
$e 2=a+b$ & \\
\hline
\end{tabular}




\section{Results}

\section{Plasma TRP values}

The plasma TRP/ $L$ LNAA ratio is shown in Figure 1 . TRP/ $/$ LNAA levels changed over the 6 hours $(\mathrm{F}(3,60)=4.92 ; P<0.01)$. There was a treatment effect for TRP/ $L$ LNAA ratio $(\mathrm{F}(2,60)=36.72, P<0.01)$. Post hoc analysis showed that the TRP- condition was significantly different than the TRP + and the saline condition (Bonferroni, $\mathrm{P}<0.05$ ). In addition, the Time $\mathrm{x}$ Treatment interaction was also significant for the TRP/ $\mathrm{LNAA}$ ratio $(\mathrm{F}(6,60)=7.80$; $P<0.01$ ). Separate one-way ANOVA analyses for each treatment time point showed differences between treatment conditions at the $1 \mathrm{~h}$ time point $(\mathrm{F}(2,17)=31.44 ; P<0.01)$ and the $3 \mathrm{~h}$ time point $(\mathrm{F}(2,16)=6.79 ; P<0.01)$. However, no differences between treatment conditions were observed at the baseline time point $(-20 \mathrm{~min})(\mathrm{F}(2,15)=2.03$; n.s. $)$ or the $6 \mathrm{~h}$ time point $(\mathrm{F}(2.17)=3.33 ;$ n.s. $)$ (see Figure1). Furthermore, post hoc analysis showed that the TRP/ $L$ LNAA ratio of the TRP- treated animals was lower than the TRP + or saline treated animals at the $1 \mathrm{~h}$ time point (Bonferroni; $P<0.01$ ) and the $3 \mathrm{~h}$ time point (Bonferroni; $P<0.05$ ).

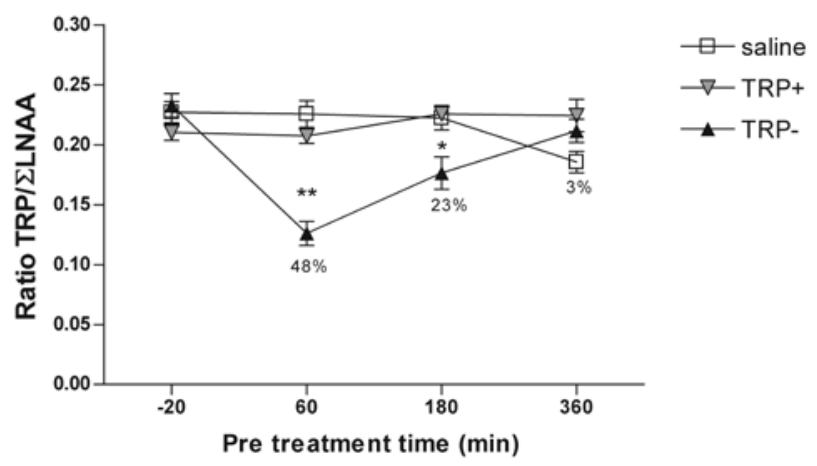

Figure 1: The effects of treatment time on the ratio plasma TRP/ $L$ LNAA (mean values and SEM). Percentages indicate the difference from baseline levels in the TRP- conditions. Asterisks indicate significant differences from baseline $\left({ }^{*} P<0.05\right.$; $\left.{ }^{* *} P<0.01\right)$

\section{Behavioral experiment 1}

The effects of ATD on ORT performance are shown in Figure 2 and Table 3. There was a general treatment effect on ORT performance $(\mathrm{F}(1,165)=36.44 ; P<0.01)$. In addition, a time effect was observed on ORT performance $(\mathrm{F}(3,165)=2.86 ; P<0.05$. The Time $\mathrm{x}$ Treatment interaction was also significant for the memory performance in the $\mathrm{ORT}(\mathrm{F}(3,165)=4.47$; $P<0.01$ ). Separate analysis per treatment condition showed that there was a significant time effect for the TRP- condition $(F(3,87)=5.41 ; P<0.01)$ in memory performance, but not for 
the TRP+ condition $(\mathrm{F}(3,84)=1.77 ; \mathrm{P}=$ n.s. $)$. Post-hoc analysis showed that object recognition performance was significantly impaired when the TRP- mixture was administered $3 \mathrm{~h}$ before the first trial.

Table 3: Exploration times in the object recognition task at baseline and after ATD. * indicates significant differences to the baseline group, $P<0.05$

\begin{tabular}{|c|c|c|c|c|c|}
\hline & & $\mathrm{T} 1-30 \mathrm{~min}$ & $\mathrm{~T} 1-1 \mathrm{~h}$ & $\mathrm{~T} 1$ - 3h & $\mathrm{T} 1-6 \mathrm{~h}$ \\
\hline \multicolumn{6}{|l|}{ A) TRP + } \\
\hline & el & $26.62(2.09)$ & $32.30(1.37)$ & $27.82(2.06)$ & $29.00(2.50)$ \\
\hline & e2 & $33.64(2.40)$ & $49.78(3.11)^{*}$ & $28.61(2.39)$ & $28.37(2.15)$ \\
\hline \multicolumn{6}{|l|}{ B) TRP - } \\
\hline & el & $26.97(2.11)^{\circ}$ & $30.39(1.78)$ & $29.29(1.66)$ & $24.98(1.53)$ \\
\hline & e2 & $39.26(4.17)$ & $37.32(2.40)$ & $30.06(1.77)$ & $28.91(2.69)$ \\
\hline
\end{tabular}

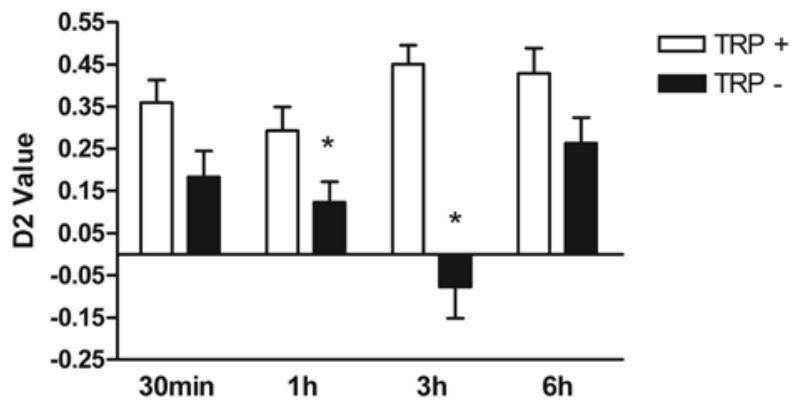

Pre-treatment time

Figure 2: The effects of treatment time of TRP+ or TRP- on the performance in object recognition task. Asterisks indicate a significant impairment in object recognition performance $\left({ }^{*} P<0.05\right)$.

\section{Behavioral experiment 2}

The effects of ATD in combination with rolipram on object recognition performance are depicted in Figure 3 and Table 4. A dose dependent increase in discrimination performance was observed after treatment with rolipram $(\mathrm{F}(4,104)=6.85 ; P<0.01)$. Post-hoc analysis showed that a dose of $0.1 \mathrm{mg} / \mathrm{kg}$ rolipram reversed the effects of TRP- treatment $(P<0.05)$. Rolipram treatment decreased exploration times in the first trial $(F(4,106)=16.24 ; P<0.01)$, but had no effect on exploration times the second trial $(\mathrm{F}(4,106)=1.53$; n.s.; see Table 4). 
Post hoc analysis showed that for all of the rolipram doses the exploration in the first trial was lower than the saline control condition.

A comparison between the $\mathrm{d} 2$ values of the control groups of the first and second experiment (TRP $3 \mathrm{~h}$ vs. saline) showed that there was no difference between these two control groups $(\mathrm{t}(38)=0.906$; n.s. $)$.

Table 4: Exploration times in the object recognition task after treatments with rolipram and TRP- mixture. ${ }^{*}$ indicates significant differences to the baseline group, $P<0.05$

\begin{tabular}{cccccc}
\hline & Saline & Vehicle & $0.01 \mathrm{mg} / \mathrm{kg}$ & $0.03 \mathrm{mg} / \mathrm{kg}$ & $0.1 \mathrm{mg} / \mathrm{kg}$ \\
TRP- & TRP- & TRP- & TRP- \\
\hline Saline & $28.72(2.52)$ & $26.18(1.72)$ & $19.15(1.66)^{*}$ & $18.68(1.35)^{*}$ & $12.02(1.53)^{*}$ \\
$e 2$ & $28.73(1.42)$ & $27.43(1.80)$ & $21.68(1.96)$ & $27.89(2.63)$ & $27.29(2.70)$ \\
\hline
\end{tabular}

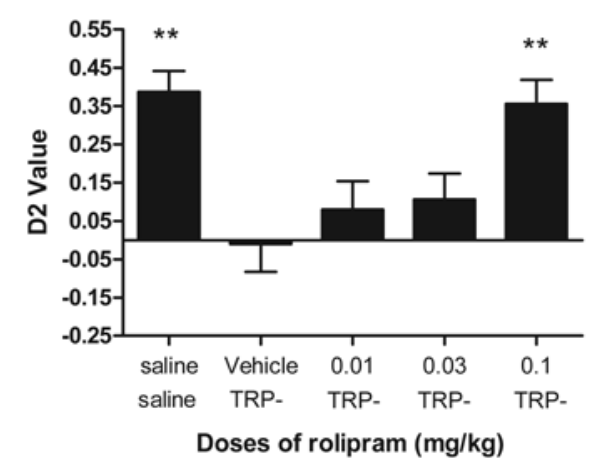

Figure 3: The effects of rolipram treatment on ATD induced deficits in the object recognition task. Asterisks indicate a significant difference in object recognition performance compared with the TRP- and vehicle condition $(* * \mathrm{P}<0.01)$. The $0.1 \mathrm{mg} / \mathrm{kg}$ dose of rolipram reverses the ATD effect.

\section{Discussion}

The present study shows that acute tryptophan depletion results in reliable lowering of plasma TRP and the TRP/LLNAA ratio. When rats were administered one dose $(10 \mathrm{ml} / \mathrm{kg})$ of the TRP- mixture, depletion was maximal (48\%) one hour after the treatment. The present data provide strong evidence that blood TRP levels predict object recognition performance and that ATD has only temporary effects on TRP levels and memory performance. When injected $3 \mathrm{~h}$ before $\mathrm{T} 1$ object recognition was maximally impaired. This is in support of the 
results from the blood TRP values (see above). Thus, TRP levels in the blood seem to be related with behavioral performance in rats. Since previous studies have shown (Lieben et al. 2004a) a clear relation between plasma TRP and central 5-HT, these data provide further support that ATD can be used as a serotonergic deficit model in the object recognition task.

In the study by Lieben at al. (2004) two doses of the TRP- mixture $(10 \mathrm{ml} / \mathrm{kg})$ were administered, which resulted in a $70 \%$ drop of the TRP/ $\mathrm{LNAA}$ ratio and in memory impairment in the ORT. In contrast, the present study showed that one dose of the TRP- mixture resulted in a $48 \%$ drop in the TRP/ $L$ LNAA ratio, which was found to induce memory impairment in the ORT. These findings suggest that a 50\% reduction in plasma TRP levels is sufficient to impair object memory in rats.

In the first behavioral experiment, no effects on exploration times in the ORT were observed, except from an increase in exploration time in the second trial of the TRP $1 \mathrm{~h}$ before $\mathrm{T} 1$ group. However, in the second experiment a dose dependent decrease in the exploration time of T1 was observed after treatment with rolipram. Previous work from our group has shown that as long as exploration in trial 1 is higher than $10 \mathrm{~s}$ a reliable discrimination index (d2) can be calculated (Sik et al. 2003). Furthermore, as can be seen when exploration times are compared to $d 2$ values, effects in exploration time are independent of effects in $d 2$ values (Sik et al. 2003). Rolipram is known to have some sedative side effects (at higher dosages $>0.1 \mathrm{mg} / \mathrm{kg}$ ) (Griebel et al. 1991; Silvestre et al. 1999), nevertheless the low dosages used in the present study improved memory performance.

Rolipram has shown its pro-cognitive effects in several behavioral models. We have shown that rolipram treatment increases object memory in a time dependent forgetting paradigm (Rutten et al. 2006a). In addition, rolipram attenuated cholinergic deficits caused by scopolamine in several behavioral tasks (Imanishi et al. 1997; Rutten et al. 2006a; Silvestre et al. 1999; Zhang and O'Donnell 2000). When rolipram $(0.1 \mathrm{mg} / \mathrm{kg})$ was administered in combination with the TRP- mixture (i.e. TRP- $3 \mathrm{~h}$ before T1 and rolipram $30 \mathrm{~min}$ before T1), we found that it reversed the effects of ATD. These are the first data suggesting that rolipram can reverse a serotonergic induced memory deficit in rats.

Our previous study indicated that rolipram can reverse the cholinergic deficit caused by scopolamine in the ORT (Rutten et al. 2006a). Remarkably, a similar dose of $0.1 \mathrm{mg} / \mathrm{kg}$ rolipram was capable of reversing the serotonergic and cholinergic deficits in the object recognition task, which might be explained by a non-specific working mechanism of rolipram. Although the underlying mechanisms of action of the memory enhancing effects of rolipram in these models remain to be determined, the present data could be explained via an enhanced cholinergic and serotonergic turnover by rolipram (Imanishi et al. 1997; Schoffelmeer et al. 1985). 
Alternatively, the effects of rolipram could also be explained in terms of only a cholinergic mechanism of action. Thus, previous studies have shown that the acetylcholinesterase (AChE) inhibitor metrifonate ameliorates the effects of ATD as well and improves performance in scopolamine deficit models of the ORT (Lieben et al. 2005b). This suggests that the cholinergic and serotonergic systems act in a synergistic manner in memory performance (see Lieben et al. 2005b for a detailed discussion). Clearly, further research is needed to scrutinize the mechanism of action rolipram in the different animal models of memory.

Another mechanism of action of rolipram that could explain the present data is related to the intracellular signaling in long-term potentiation (LTP). In the hippocampus, rolipram has shown to improve LTP through activation of the cAMP/PKA/CREB pathway (Frey et al. 1993; Impey et al. 1996). Moreover, these mechanisms have been linked to behavioral improvement in several behavioral tasks (Barad et al. 1998; Bernabeu et al. 1997; Blokland et al. 2006a; Rutten et al. 2006a). Consequently, it could be argued that the present data could be explained by the effects of rolipram on the CAMP/PKA/CREB pathway. However, a recent study by our group showed that the administration time of rolipram was of critical relevance. Rolipram was only effective in the $24 \mathrm{~h}$ interval ORT when administered $3 \mathrm{~h}$ after T1 (Rutten et al. 2006a) and the mechanism of late LTP was proposed to explain these effects. However, in the present study a $1 \mathrm{~h}$ interval in the ORT was examined, in which no gene transcription or protein synthesis is required. Therefore, we assume that the cAMP/PKA/CREB pathway cannot explain these effects.

A recent PET study used radioactive rolipram as a measure for PDE4 binding and as an indirect index of cAMP signaling (Lourenco et al. 2006). Acute elevation of synaptic neurotransmitter levels (noradrenaline, 5-HT and histamine) resulted in elevated cAMP levels that in turn elevated (R)-[11C] rolipram binding to PDE4 (Lourenco et al. 2006). According to this rationale, elevation of cAMP levels through inhibition of PDE4 can reverse cAMP mediated deficits in behavior that occur due to a shortage of 5-HT, ie, reversing the ATD induced object recognition impairment. Since rolipram non-selectively facilitates several neurotransmitter systems, a broad mechanism of action can be expected. This can be favorable because influencing multiple systems increases the likelihood that several aspects of behavior could be enhanced. This may explain previous reports that rolipram was effective in depression models (Bobon et al. 1988; Norman et al. 1992b; Weishaar et al. 1985b). On the downside, the broad mechanism of action increases the risks for negative side effects, e.g. emesis, sedation and nausea.

Summarizing, the method of ATD can be used as a reliable method for inducing object memory impairment in rats. The selective PDE4 inhibitor rolipram was able to reverse this serotonergic deficit, which could be explained by different mechanisms of action. These data provide further support that PDE4 inhibition could be considered as a potential target to improve memory performance. 


\section{References}

Bailey CH, Bartsch D, Kandel ER (1996) Toward a molecular definition of long-term memory storage. Proc. Natl. Acad. Sci. USA 93: 13445-13452

Barad M, Bourtchouladze R, Winder DG, Golan H, Kandel E (1998) Rolipram, a type IV-specific phosphodiesterase inhibitor, facilitates the establishment of long-lasting long-term potentiation and improves memory. Proc. Natl. Acad. Sci. USA 95: 15020-15025

Bernabeu R, Bevilaqua L, Ardenghi P, Bromberg E, Schmitz P, Bianchin M, Izquierdo I, Medina JH (1997) Involvement of hippocampal cAMP/cAMP-dependent protein kinase signaling pathways in a late memory consolidation phase of aversively motivated learning in rats. Proc. Natl. Acad. Sci. USA 94: 7041-7046

Blokland A, Schreiber R, Prickaerts J (2006) Improving Memory: A role for Phosphodiesterases. Curr. Pharm. Des. 12: $2511-2523$

Bobon D, Breulet M, Gerard-Vandenhove MA, Guiot-Goffioul F, Plomteux G, Sastre-y-Hernandez M, Schratzer M, Troisfontaines B, von Frenckell R, Wachtel H (1988) Is phosphodiesterase inhibition a new mechanism of antidepressant action? A double blind double-dummy study between rolipram and desipramine in hospitalized major and/or endogenous depressives. Eur. Arch. Psychiatry Neurol. Sci. 238: 2-6

Booij L, Van der Does AJ, Riedel WJ (2003) Monoamine depletion in psychiatric and healthy populations: review. Mol. Psychiatry. 8: 951-973

Dixon WJ (1959) Analysis of extreme values. Ann. Math. Stat. 21: 488-506

Egawa T, Mishima K, Matsumoto Y, Iwasaki K, Fujiwara M (1997) Rolipram and its optical isomers, phosphodiesterase 4 inhibitors, attenuated the scopolamine-induced impairments of learning and memory in rats. Jpn. J. Pharmacol. 75: 275-281

Fernstrom JD (1981) Dietary precursors and brain neurotransmitter formation. Annu. Rev. Med. 32: 413-425

Fluttert M, Dalm S, Oitzl MS (2000) A refined method for sequential blood sampling by tail incision in rats. Lab. Anim. 34: 372-378

Frey U, Huang YY, Kandel ER (1993) Effects of cAMP simulate a late stage of LTP in hippocampal CA1 neurons. Science 260: 1661-1664

Griebel G, Misslin R, Vogel E, Bourguignon JJ (1991) Behavioral effects of rolipram and structurally related compounds in mice: behavioral sedation of cAMP phosphodiesterase inhibitors. Pharmacol. Biochem. Behav. 39: 321-323

Imanishi T, Sawa A, Ichimaru Y, Miyashiro M, Kato S, Yamamoto T, Ueki S (1997) Ameliorating effects of rolipram on experimentally induced impairments of learning and memory in rodents. Eur. J. Pharmacol. 321: 273-278

Impey S, Mark M, Villacres EC, Poser S, Chavkin C, Storm DR (1996) Induction of CRE-mediated gene expression by stimuli that generate long-lasting LTP in area CA1 of the hippocampus. Neuron 16: 973-982

Lieben CK, Blokland A, Ş1k A, Sung E, van Nieuwenhuizen P, Schreiber R (2005) The selective 5-HT6 receptor antagonist Ro4368554 restores memory performance in cholinergic and serotonergic models of memory deficiency in the rat. Neuropsychopharmacology 30: 2169-2179

Lieben CK, Blokland A, Westerink B, Deutz NE (2004a) Acute tryptophan and serotonin depletion using an optimized tryptophan-free protein-carbohydrate mixture in the adult rat. Neurochem. Int. 44: 9-16

Lieben CK, van Oorsouw K, Deutz NE, Blokland A (2004b) Acute tryptophan depletion induced by a gelatin-based mixture impairs object memory but not affective behavior and spatial learning in the rat. Behav. Brain. Res. 151: 53-64

Lourenco CM, Kenk M, Beanlands RS, DaSilva JN (2006) Increasing synaptic noradrenaline, serotonin and histamine enhances in vivo binding of phosphodiesterase-4 inhibitor (R)-[11C]rolipram in rat brain, lung and heart. Life. Sci. 79: 356-364

Norman TR, Judd FK, Burrows GD (1992) New pharmacological approaches to the management of depression: from theory to clinical practice. Aust N Z J Psychiatry 26: 73-81

Park SB, Coull JT, McShane RH, Young AH, Sahakian BJ, Robbins TW, Cowen PJ (1994) Tryptophan depletion in normal volunteers produces selective impairments in learning and memory. Neuropharmacology 33: $575-588$ 
Prickaerts J, de Vente J, Honig W, Steinbusch HW, Blokland A (2002) cGMP, but not cAMP, in rat hippocampus is involved in early stages of object memory consolidation. Eur. J. Pharmacol. 436: 83-87

Prickaerts J, Steinbusch HW, Smits JF, de Vente J (1997) Possible role of nitric oxide-cyclic GMP pathway in object recognition memory: effects of 7-nitroindazole and zaprinast. Eur. J. Pharmacol. 337: 125-136

Riedel WJ, Klaassen T, Deutz NE, van Someren A, van Praag HM (1999) Tryptophan depletion in normal volunteers produces selective impairment in memory consolidation. Psychopharmacology (Berl) 141: 362-369

Rose GM, Hopper A, De Vivo M, Tehim A (2005) Phosphodiesterase inhibitors for cognitive enhancement. Curr. Pharm. Des. 11: 3329-3334

Rutten K, Prickaerts J, Blokland A (2006) Rolipram reverses scopolamine-induced and time-dependent memory deficits in object recognition by different mechanisms of action. Neurobiol. Learn. Mem. 85: 132-138

Schmitt JA, Jorissen BL, Sobczak S, van Boxtel MP, Hogervorst E, Deutz NE, Riedel WJ (2000) Tryptophan depletion impairs memory consolidation but improves focussed attention in healthy young volunteers. J. Psychopharmacol. 14: 21-29

Schoffelmeer AN, Wardeh G, Mulder AH (1985) Cyclic AMP facilitates the electrically evoked release of radiolabelled noradrenaline, dopamine and 5-hydroxytryptamine from rat brain slices. Naunyn Schmiedebergs Arch. Pharmacol. 330: 74-76

Şık A, van Nieuwehuyzen P, Prickaerts J, Blokland A (2003) Performance of different mouse strains in an object recognition task. Behav. Brain. Res. 147: 49-54

Silvestre JS, Fernandez AG, Palacios JM (1999) Preliminary evidence for an involvement of the cholinergic system in the sedative effects of rolipram in rats. Pharmacol. Biochem. Behav. 64: 1-5

Van Eijk HM, Rooyakkers DR, Deutz NE (1993) Rapid routine determination of amino acids in plasma by highperformance liquid chromatography with a 2-3 microns Spherisorb ODS II column. J. Chromatogr. 620: 143-148

Weishaar RE, Cain MH, Bristol JA (1985) A new generation of phosphodiesterase inhibitors: multiple molecular forms of phosphodiesterase and the potential for drug selectivity. J. Med. Chem. 28: 537-545

West AR, Galloway MP (1996) Regulation of serotonin-facilitated dopamine release in vivo: the role of protein kinase $A$ activating transduction mechanisms. Synapse 23: 20-27

Wurtman RJ, Hefti F, Melamed E (1980) Precursor control of neurotransmitter synthesis. Pharmacol. Rev. 32: 315-335

Zhang HT, Crissman AM, Dorairaj NR, Chandler LJ, O'Donnell JM (2000) Inhibition of cyclic AMP phosphodiesterase (PDE4) reverses memory deficits associated with NMDA receptor antagonism. Neuropsychopharmacology 23: 198-204

Zhang HT, O'Donnell JM (2000) Effects of rolipram on scopolamine-induced impairment of working and reference memory in the radial-arm maze tests in rats. Psychopharmacology (Berl) 150: 311-316

Zhang HT, Zhao Y, Huang Y, Dorairaj NR, Chandler LJ, O’Donnell JM (2004) Inhibition of the phosphodiesterase 4 (PDE4) enzyme reverses memory deficits produced by infusion of the MEK inhibitor U0126 into the CA1 subregion of the rat hippocampus. Neuropsychopharmacology 29: 1432-1439 


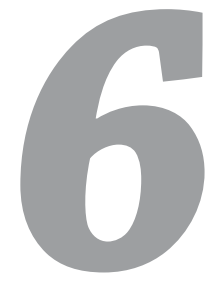

\title{
BEHAVIORAL EFFECTS OF PDE4-D AND PDE4-B KNOCK-OUT MICE IN MODELS OF LEARNING AND MEMORY
}

\author{
Kris Rutten, Melissa Works, Arjan Blokland, \\ Luca Santarelli, Tanya Wallace-Boone
}

\section{Awaiting clearance from Roche Palo Alto for submission}

Sustained activation of cyclic adenosine monophosphate (cAMP) and subsequent phosphorylation of cAMP responsive element binding protein (CREB) is believed to be a critical mediator of long-term memory (LTM) formation. Consistent with this hypothesis, pharmacological inhibition at the level of the phosphodiesterase 4 (PDE4), the primary enzyme responsible for the breakdown of CAMP results in memory enhancement in several cognitive behavioral tasks across multiple species. Currently, four isoforms of the PDE4 enzyme (A, B, C and D) have been identified, yet the requisite involvement of each of these isoforms in mediating LTM has yet to be elucidated, in part because selective small molecule isoform inhibitors have not been characterized. The intent of the present study was to use genetic knockout mice to investigate the involvement of two of the PDE4 isoforms that have high brain expression, namely D and $\mathrm{B}$, in in vivo models of learning and memory. Adult, male PDE4-D and PDE4-B knock-out mice were first characterized in an associative learning paradigm using the fear conditioning model (FC) at two time points, 24 hours for long term memory (LTM), and 1 hour for short term memory (STM). Interestingly, whereas the PDE4 B knock out mice demonstrated equivalent LTM and STM as compared to wildtype mice, the PDE4-D knock-out animals exhibited significant deficits in LTM as compared with their control littermates. The impairment in LTM observed in the PDE4D knockout mice could not be attributed to differences in acquisition of the FC task (i.e., STM), alterations in locomotor activity or effects on shock sensitivity, as there were no significant genotype effects in any of these measures. Neither the PDE4B or PDE4D mice showed any alterations in MWM performance (acquisition or retention) as compared to wildtype controls. Whereas the deficit in LTM observed in the PDE4D knockout mice was not expected, and may be explained by adaptive responses occurring because of constitutive inactivity of this isoform throughout development, it does suggest that the PDE4D isoform, possibly more so than PDE4B may be of importance in learning and memory. 


\section{Introduction}

Activation of the cAMP (cyclic adenosine monophosphate)/protein kinase-A (PKA) /CREB pathway has been proposed to mediate long term potentiation (LTP) and memory (Ahi et al. 2004; Barco et al. 2003; Bernabeu et al. 1997; Bourtchouladze et al. 2003; Comery et al. 2005; Frey et al. 1993). In particular, cAMP plays an important role in intracellular signaling (Bailey et al. 1996) and in processes of neuroplasticity and is believed to be involved in the processes of late phase LTP and late memory consolidation (Rose et al. 2005; Rutten et al. 2006a). The degradation of cAMP and cGMP cyclic guanine monophosphate, a closely related cyclic nucleotide, is regulated by phosphodiesterase (PDE) enzymes. The family of PDEs is relatively large and eleven different isozymes have been identified thus far. Several studies have shown memory enhancing effects of phosphodiesterase inhibitors (PDE-Is) in many different species and in a large array of memory tasks (for review see Blokland et al. 2006, in press). At present, the studies that describe effects of selective PDEs on memory performance have concentrated on inhibitors of PDE4 (i.e. Rose et al. 2005), PDE5 (i.e. Prickaerts et al. 2004) and more recently PDE2 (i.e. Boess et al. 2004). PDE4 and PDE5 are specific inhibitors of cAMP or cGMP, respectively, whereas PDE2 hydrolyzes both cAMP and cGMP.

Within the PDE4 family, four PDE4 subtypes have been characterized, namely PDE4 A, $\mathrm{B}, \mathrm{C}$, and D. Whereas PDE4 is ubiquitously expressed in the brain, the PDE4-B and D isoforms are more widely expressed than PDE4 A and C (Perez-Torres et al. 2000). In particular, PDE4$B$ and PDE4-D are present in cortex, hippocampus, hypothalamus, midbrain and cerebellum, with PDE4-B being specifically enriched in the striatum (Blokland et al. 2006, in press). In the amygdala and the hippocampus PDE4-B and D are both expressed but not equally.

At present, it is unknown which PDE4 isoform (s) is involved in mediating synaptic plasticity and cognitive enhancing effects. Previous studies showed that intra-hippocampal infusions of cAMP analogs (e.g., 8-Br-cAMP, sp-cAMPs) improved learning in memory in animals models of cognition (Bernabeu et al. 1997; Bernabeu et al. 1996). Similar results were observed after infusions of 8-Br-cGMP in the rat hippocampus in another one trial learning task, the object recognition task (Prickaerts et al. 2002a). The most widely characterized PDE4 inhibitor, rolipram, has demonstrated cognitive enhancing properties in several animal models of learning and memory (Bourtchouladze et al. 2003; Rutten et al. 2006a; Zhang et al. 2000; Zhang et al. 2005; Zhang et al. 2004). In addition, PDE4 inhibitors can reverse memory impairments in several mouse models of disease (e.g., Alzheimer's disease) (Bourtchouladze et al. 2003; Comery et al. 2005; Gong et al. 2004).

Whereas PDE4 inhibitors are enticing targets for the treatment of cognitive impairing disease such as Alzheimer's, it has been very difficult to circumvent the adverse effects that often accompany the beneficial effects of the PDE4-Is. Thus, one approach to minimize the adverse effects would be to develop selective PDE4 isoform inhibitors depending on the characterization and understanding of which isoform (s) was involved in learning/memory. It was the intent of the present study to use genetic knock out mice with selective deletions 
of either the PDE4B or PDE4D isoform to identify whether either or both of these subtypes is involved in mediating LTM. Characterization of specific isoform functions can provide better understanding of the mechanism for cognitive enhancement of PDE4 inhibition and the augmentation of pro-cognitive drugs.

\section{Methods}

\section{Generation of PDE4-D \& B KO mice}

The generation of the PDE4-D- and PDE4-B-deficient mice has been described previously (Jin et al. 2005). For both lines the effect of the null PDE4 allele was tested on mice of a mixed background (C57BL/6 x 129/Ola) using wild-type littermates as controls. Colonies were established and maintained by out-breeding heterozygous pairs and genotyping the offspring. A total of 184 young adult male (25-30g) transgenic, PDE4-D ( $\mathrm{n}=92)$ and PDE4-B ( $\mathrm{n}=92)$ mice, were used in the characterization experiments. The mice used in the present studies were all adults between the ages of 10-23 weeks of age. All animals were housed in standard Allentown mouse cages on corncob bedding ( $n=1-8 /$ cage, depending on littermate availability) in a temperature controlled room (about $20^{\circ} \mathrm{C}$ ). They were kept under a regular 12/12-hour light/dark cycle (lights on from 6.00h to 18.00h) and had free access to food and water. All experimental procedures were approved by the Institutional Animal Care and Use Committee (IACUC) of Roche Palo Alto and were in accordance with NIH guidelines.

\section{Apparatus:}

\section{Fear Conditioning}

Training took place in 8 identical mouse fear conditioning boxes (Coulbourn Instruments, Allentown, PA). The floor was a metal grid $(17.8 \mathrm{~cm}$ long $\times 17.8 \mathrm{~cm}$ wide $\times 30.5 \mathrm{~cm}$ high) connected to a shock generator (model H13-15) used to administer foot shocks (0-1.0 mA). Each fear conditioning box was dimly lit (3-8 lux) by a single house light and was enclosed by a sound attenuating chamber. The boxes were equipped with a $24 \mathrm{~V}$ speaker and on top of each box a digital camera was mounted which was connected to a computer system that automatically monitored freezing behavior (Freezeframe, Coulbourn Instruments, Allentown, PA). The threshold for detecting freezing was set at 15 and was based on empirically collected data comparing manual and automatic scoring measurements. Freezing was defined as a total lack of movement except for respiration.

On the day of training and testing mice were brought into the test room with free access to food and water. The animals were then weighed and acclimated to the test room for $60 \mathrm{~min}$. The fear conditioning test consisted of a training phase and a test phase conducted $24 \mathrm{~h}$ later. Before each training and testing session the conditioning boxes were cleaned with an $85 \%$ ethanol solution. 
On the training day, each mouse was placed in a conditioning box and was allowed to explore the new environment for 120s. Next a tone (CS, $3000 \mathrm{~Hz}, 85 \mathrm{~dB}$ ) was presented for 30 s that co-terminated with a 2 s foot shock (0, 0.4 or $1 \mathrm{~mA}$ ) (US). A second CS/US pairing was presented after an inter stimulus interval (ISI) of 120s. After the second shock the mice remained in the training box for 30 seconds before being returned to their home cages.

On the test day, conducted 1 hr (short-term memory) or 24 hr (long-term memory) after training, mice were returned to the testing room and each mouse was placed in the same chamber used for training and the association between the context and the aversive US (foot shock) was measured by means of freezing behavior over a 5 minute period (i.e., context test). Freezing behavior was monitored automatically.

Approximately, one hour after contextual fear testing, the environmental conditions of the testing room were changed in preparation for the cue test, in which an altered context was created. Cue tests were conducted in standard mouse cages with sawdust bedding and covered with filter tops. The boxes were scented with orange extract and the testing room itself was cleaned with a different disinfectant (Lysol instead of 85\% ethanol) to minimize similarity to the original conditioning environment. During the cue test a radio provided soft background noise and the test room was divided into a smaller segment as compared to the original conditioning session by a black curtain. Next, the association between the auditory cue (CS) and the aversive foot shock (US) were measured manually by monitoring freezing behavior (i.e., altered context/cue test). In this test, four mice were scored simultaneously by a blinded observer at 4 second intervals each mouse was judged as either freezing or active. For the altered context (cue) test, baseline freezing was scored for the first 120 s (pre-CS).

\section{Morris water maze (MWM)}

The testing room consisted of a circular, galvanized steel pool 1.42 meters in diameter, painted white, filled with $22^{\circ} \mathrm{C}$ water and $250 \mathrm{~mL}$ of white, latex indoor house paint to make the water opaque. The pool was surrounded by curtains that could be drawn, and around the room, bright and bold visual cues were displayed on the walls. These extra-maze cues were kept constant throughout the training and testing period. The pool was divided into four quadrants (North, West, South, East) and a $13 \mathrm{~cm}$ white, circular platform was placed $1.5 \mathrm{~cm}$ below the surface of the water in the North quadrant. Centered above the pool, a camera (Panasonic, Secaucus, NJ) was connected to an HP computer loaded with a visual tracking program (Noldus Ethovision, Leesburg, VA).

Mice were subjected to the following testing schedule for MWM: spatial navigation with acquisition and probe trials (days 1-5), reversal learning (days 6 \& 7), and cued navigation (day 8). Acquisition of spatial navigation (days 1-4) consisted of 4 trials per day with a 10-minute inter-trial interval where mice were trained to use spatial cues to reach a hidden platform. Each trial started with the mouse facing the wall of the pool and ended when the mouse reached the platform, or 60 seconds, which ever came first. Starting positions were balanced in a Latin Square design so that no mouse started the trials in the same loca- 
tion order. If the mouse failed to find the platform, it was guided to the platform location with a prop (an immobilized paint roller). At the end of the trial, the mouse was allowed to stay on the platform for approximately 10 seconds and was then taken off the platform via the prop. On day 3, 1.5 hours after the last acquisition trial, and day 5, 24 hours after the last acquisition trial, the platform was removed from the tank and the mouse was allowed to swim in the tank for 60 seconds. Reversal learning (days 6 and 7) consisted of 4 trials per day with a 10-minute inter-trial interval in which the platform was moved to the East quadrant. Starting positions were balanced in a Latin Square design. The mouse was given 60 seconds to find the platform and allowed to stay on the platform for approximately 10 seconds. Cued navigation (day 8), which tested swimming ability and visual acuity, consisted of 4 trials per day with a 10-minute inter-trial interval. The curtains were closed around the pool and the platform was placed in the center of the pool. An object was placed in the center of the platform to act as a "cue". Starting positions were balanced in a Latin Square design. The mouse was given 60 seconds to find the platform and allowed to stay on the platform for approximately 10 seconds. Comparisons of path length $(\mathrm{cm})$ in acquisition, reversal, and cued tests, and percent distance in each quadrant in probe trials were performed between $\mathrm{KO}$ and WT mice.

\section{Learning Capacity Test in Morris Water Maze}

In modified version of the Morris water maze, another group of mice were tested for learning capacity. In this test, mice had a maximum of 8 (60-second) trials per day to locate the hidden platform using spatial cues. If the mouse was able to reach the platform in an average of 21 seconds over three consecutive trials (i.e., reached "criteria"), then testing ended for the day. The next day, the platform was moved to a new location and the mouse was given another 8 trials. If the mouse did not reach criteria on a given day, testing ended after 8 trials and the platform was placed in the same location the next day. For any given trial location, subjects were allowed a maximum of 4 days, or 32 trials, before the platform was moved to the next location automatically. Mice experienced a maximum of 10 platform locations. Half of the mice experienced the platforms locations in the order of 1 to 10 , while the other half experienced the platforms in the order of 10 to 1 , in order to account for platform location order bias. The platform locations were dispersed throughout the pool to account for quadrant bias. Average trials to criterion and number of platforms experienced were compared between $\mathrm{KO}$ and WT mice.

\section{Locomotor activity (LMA)}

Loco-motor activity was measured in 10 identical test chambers. The chambers were square ( $1 \times \mathrm{b} \times \mathrm{h})$ and equipped with laser beams and photocells that were aligned to create a grid. The boxes were connected to a computer system that automatically tracked an animal's movement and calculated the total distance moved (Med Associates, St. Albans, VT). Mice were 
placed inside a test chamber $(27.9 \mathrm{~cm} \times 27.9 \mathrm{~cm})$ equipped with 16 infrared beam arrays to monitor distance traveled, and were allowed to explore the chamber freely for $60 \mathrm{~min}$. Before and after each session the boxes were cleaned with $85 \%$ ethanol solution. The dependent measure in this task was the total distance traveled $(\mathrm{cm})$.

\section{Shock sensitivity}

Tests for sensitivity to shock were conducted inside the fear conditioning chambers. A mouse was placed in a test chamber and was administered five foot shocks of increasing amplitude $(0,0.2,0.4,0.8$ and $1.0 \mathrm{~mA})$ with an ITI of 30s. An observer, blinded to genotype, scored shock sensitivity in the PDE4-D and B mice, based on three behavioural categories: flinching, running/jumping and vocalizing. For each mouse individual, scores from naïve $\mathrm{KO}$ and naïve WT animals were averaged and compared. The dependent measure in this task was the average amplitude to first detect flinching, running/jumping or vocalizing.

\section{Statistical analysis}

For all behavioral experiments, scores were averaged per genotype and compared in a between subjects design. A correlation analysis was performed to assess the effect of shock amplitude on freezing behavior in the shock response curve experiment for both automatic and manual scoring. Analysis of the shock dependent freezing experiment for the PDE4-D and B wild-types, a one-way ANOVA test was performed with shock intensity as factor and freezing behavior as dependent variable. A Bonferroni post hoc test was performed in case of statistical significant effects. Furthermore, differences between genotypes (wild-type vs. knock-out for both PDE4-B and -D) in LTM, STM, LMA and shock sensitivity were assessed by means of independent sample t-tests $(p<0.05=$ significant result). Differences between genotypes in MWM were assessed by two-way repeated measures ANOVA (day and genotype) for acquisition and reversal and two-way ANOVA (zone and genotype) for probe trials. Differences between the genotypes in the learning capacity test were assessed by two-way repeated measures ANOVA (trials to criterion and genotype) and two-way ANOVA (average trials to criterion and genotype; number of platforms experienced and genotype). A Bonferroni post hoc test was performed in case of statistically significant effects.

\section{Results}

Figure 1 shows the effect of shock intensity (0, 0.4 or $1 \mathrm{~mA}$ ) on context and cue dependent freezing for PDE4-D and PDE4-B wild-type mice. For the PDE4-D mice a difference in freezing behavior was observed between different shock amplitudes $(F(2,41)=42.47$; $P<0.01$ ) (Figure 1A). As expected, the sham group was significantly lower as compared to the 0.4 and $1 \mathrm{~mA}$ group (Bonferroni, $P<0.01$ ). Furthermore a shock dependent increase in freezing behavior in the context test was observed. Moreover, the cue test for all shock groups showed a significant increase between pre and post cue freezing $\left(\mathrm{T}_{0 \mathrm{~mA}}(13)=-3.75\right.$; 
$\left.\mathrm{T}_{0.4 \mathrm{~mA}}(13)=-5.50, \mathrm{~T}_{1 \mathrm{~mA}}(13)=5.52 ; P<0.01\right)$. An increase in freezing during the CS is indicative of a learned association of the CS with the US. Furthermore, the PDE4-B wild-type animals showed similar results as the PDE4-D wild-type animals (Figure 1B). Differences between freezing levels were observed between shock amplitudes $(\mathrm{F}(2,41)=12.86 ; P<0.01)$. Freezing behavior in both $0.4 \mathrm{~mA}$ and $1 \mathrm{~mA}$ conditions was higher than the $0 \mathrm{~mA}$ condition (Bonferroni, $P<0.01$ ). The cue test for all shock groups showed a significant increase between pre and post cue freezing $\left(\mathrm{T}_{0 \mathrm{~mA}}(13)=-3.75 ; \mathrm{T}_{0.4 \mathrm{~mA}}(13)=-8.48, \mathrm{~T}_{1 \mathrm{~mA}}(13)=-6.86 ; P<0.01\right)$. A strong correlation in shock dependent freezing behavior exists between C57/Bl control animals and the PDE4-D ( $r=0.72)$ and PDE4-B $(r=0.78)$ wild-types (data not shown).

PDE4 D

A

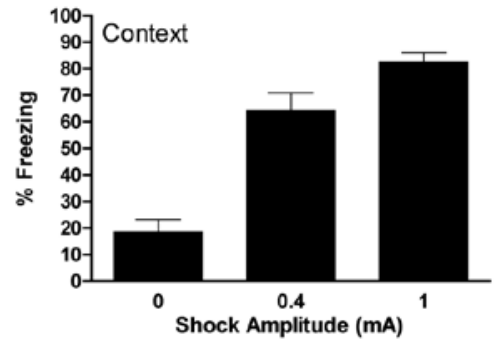

B

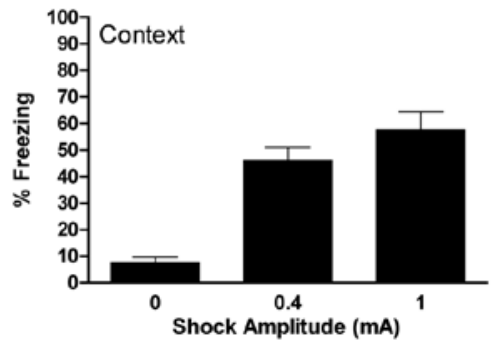

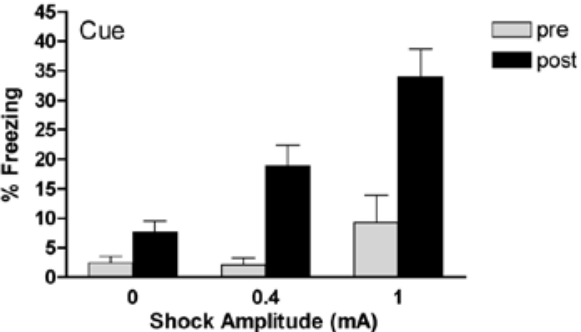

PDE4 B

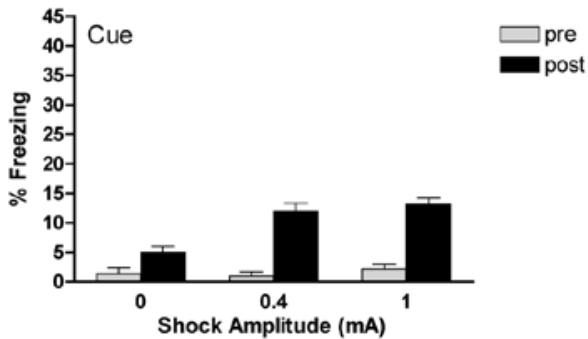

Figure 1: Shock amplitude dependent increases in freezing behavior for context test and cue test. A) Freezing behavior for PDE4-D wildtype mice ( $\mathrm{n}=14$ /group). B) Freezing behavior for PDE4-B wild-type mice ( $\mathrm{n}=14$ /group).

\section{Characterization of PDE4 KO mice}

Previous work showed that wild-type littermates of the PDE4-D and B knock-out strains performed equal to C57/B16 mice in the fear conditioning paradigm (data not shown).

To characterize the effects of the isoform specific knock-out on learning and memory as assessed by fear conditioning, we chose a shock intensity $(0.4 \mathrm{~mA})$ that would enable measuring effects on enhancement (i.e., freezing) and on impairment (i.e., decrease in freezing) of memory. The results for the long and short term memory fear conditioning for PDE4-D 
mice are depicted in Figure 2A and 2B. No differences between genotypes were observed in the training session of the fear conditioning task (data not shown). For the PDE4-D mice differences were observed on basis of genotype in the context test, 24h after training with 2 CS/US pairings of $0.4 \mathrm{~mA}(\mathrm{t}(28)=3.58$; $P<0.01)$. PDE4-D KO mice exhibited a significant deficit in LTM compared to WT animals. In addition, it was of interest to characterize how PDE4-D mice acquired the association between the CS-US as compared to wild-type mice by measuring freezing levels at $1 \mathrm{hr}$ after training. The right panel of Figure 3A shows, that PDE4-D KO and WT mice equally obtained the association between tone and shock $\left(\mathrm{t}_{\mathrm{WT}}(28)=\right.$ -9.78; $\left.\mathrm{t}_{\mathrm{KO}}(29)=-6.72 ; P<0.01\right)$. There were no differences in freezing behavior between $\mathrm{KO}$ and WT in the (post)cue test $(\mathrm{t}(28)=-0.98 ; P=$ n.s.) Heterozygous animals showed similar results as the wild-type animals (data not shown). Figure $3 \mathrm{~B}$ shows the comparison of genotypes in the short term memory task of fear conditioning. No differences were observed between PDE4-D KO and WT mice for contextual freezing $(\mathrm{t}(4)=0.53 ; P=n . s)$ and neither for (post)cue freezing $(1 . t(4)=0.51 ; P=$ n.s.). Both groups did show a significant increase of cue associated freezing $\left(\mathrm{t}_{\mathrm{WT}}(10)=-8.24 ; \mathrm{t}_{\mathrm{KO}}(4)=-9.35 ; P<0.01\right)$.

No differences between knock-outs and wild-types were observed for the PDE4-B mice in LTM fear conditioning test (Figure 3). Training with 2CS/US pairings with $0.4 \mathrm{~mA}(\mathrm{t}(13)=$ $0.27 ; P=$ n.s.) did not reveal any differences in context test. The (post)cue test did not reveal any differences between genotypes $(t(13)=1.10 ; P=n . s)$. However, the difference between pre and post cue freezing indicates that both genotypes learned the association between CS and US $\left(\mathrm{t}_{\mathrm{WT}}(13)=-8.48 ; \mathrm{t}_{\mathrm{KO}}(15)=-7.24 ; P<0.01\right)$.
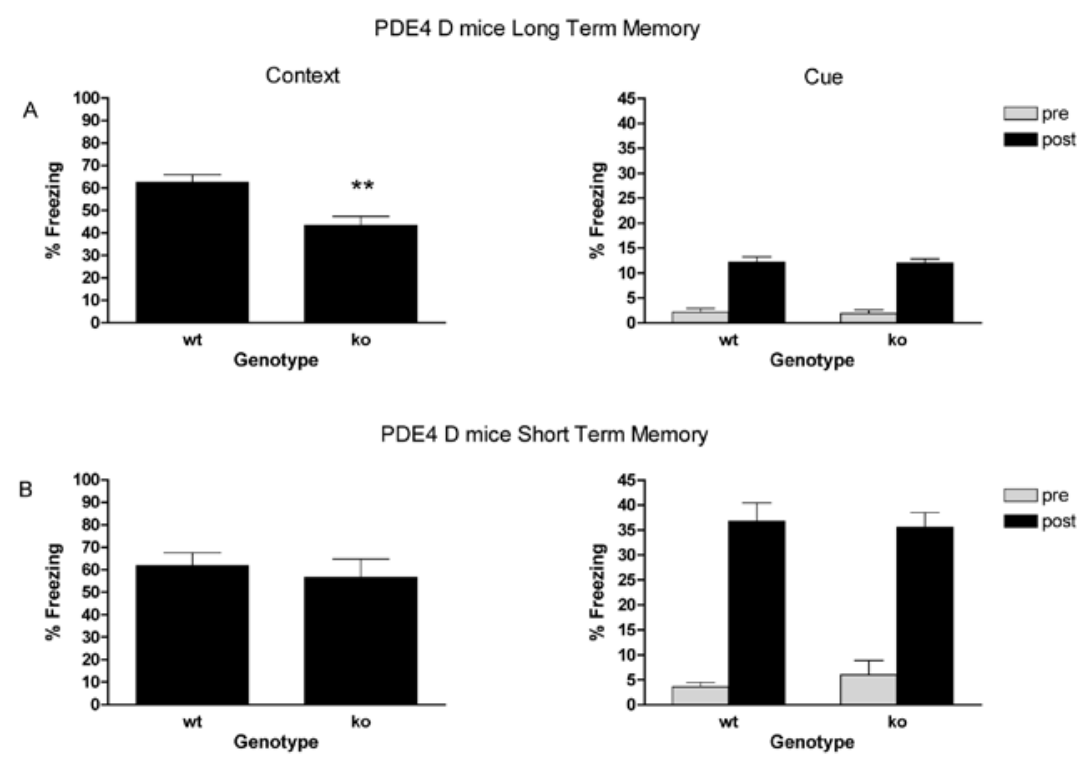

Figure 2: Freezing behavior of PDE4-D wild-types vs. knock-outs in context and cue test after training with 2 CS/US pairings (0.4 mA). A) Long term memory fear conditioning (24h between training and testing) $\mathrm{n}=16 /$ group, B) Short term memory fear conditioning (1h between context and testing) $n=8 /$ group. 
Comparison of PDE4-B wild-types and knock-outs in the short term memory fear conditioning task showed no differences in contextual freezing $(t(7)=0.04 ; P=n . s$.$) and$ neither for cue freezing $(\mathrm{t}(7)=0.04 ; P=$ n.s.) Thus, the $\mathrm{KO}$ mice performed equal to the WT mice in the short term version of fear conditioning in both strains. The difference between pre and post cue freezing indicates that both genotypes learned the association between CS and US $\left(\mathrm{t}_{\mathrm{WT}}(7)=-8.37 ; \mathrm{t}_{\mathrm{KO}}(7)=-585 ; P<0.01\right)$.

Locomotor activity for both PDE4-D and PDE4-B mice is shown in Figure 4. When comparing between genotypes (wild-type and knock-out) no significant differences in LMA were found on basis of genotype in neither the PDE4-D $(t(13)=1.8, P=$ n.s. $)$ nor the PDE4-B ( $\mathrm{t}(13)=-2.12, P=$ n.s.) animals. The general activity level of the PDE4-B mice was higher than the PDE4-D mice for both wild-types $(t(13)=-3.41 ; P<0.01)$ and knock-outs $(\mathrm{t}(13)=-6.60 ; P<0.01)$.

To determine that PDE4-D and PDE4-B knock-out mice showed equal sensitivity to the shock stimulus as compared to the wild-type littermates, naïve mice underwent delivery of brief (1s), ascending shocks from ( $0 \mathrm{~mA}$ to $1.0 \mathrm{~mA})$. The average amplitude to first detect flinching, running/jumping or vocalizing behavior was calculated (Figure 5). The lower shock amplitudes generally elicited flinching behavior, whereas the higher shock amplitudes induced running and jumping behavior. Vocalizing occurred on average from $0.3 \mathrm{~mA}$ and up for both groups. No differences between WT and $\mathrm{KO}$ animals were observed in the different categories of shock sensitivity for either the PDE4-D or PDE4-B animals (see Table 1 for statistics)

\section{PDE4 B mice Long Term Memory}
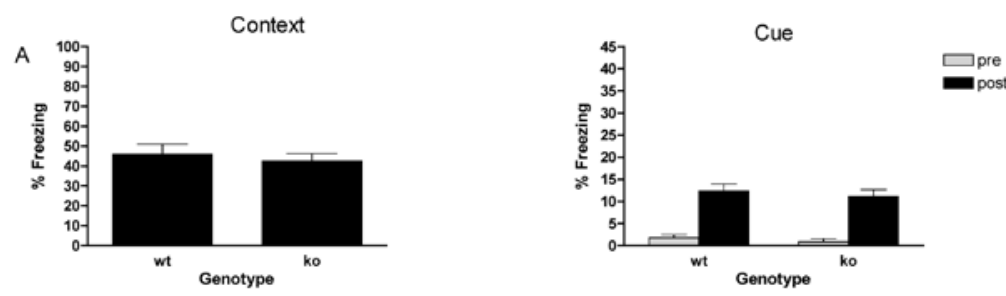

PDE4 B mice Short Term Memory
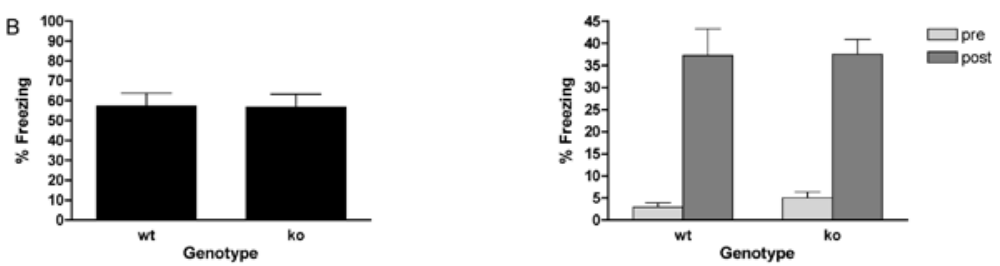

Figure 3: Freezing behavior of PDE4-B wild-types vs. knock-outs in context and cue test after training with 2 CS/US pairings (0.4 mA). A) Long term memory fear conditioning (24h between training and testing) $\mathrm{n}=16 /$ group, B) Short term memory fear conditioning (1h between context and testing) $n=8 /$ group. 

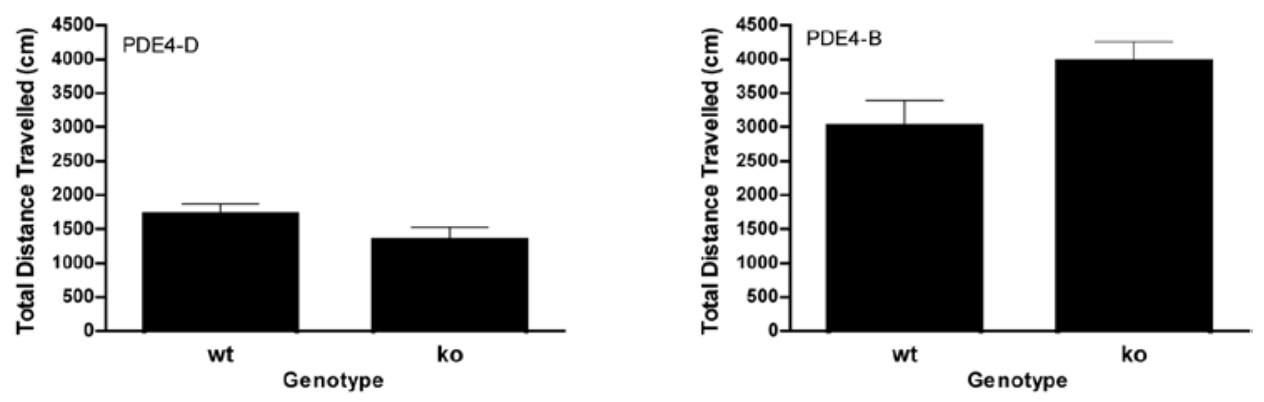

Figure 4: Loco-motor activity. Left: Total distance moved forPDE4-D wild-types vs.. knock-outs (n=16/group), and Right: distance moved forPDE4-B wild-types vs.. knock-outs (n=16/group).

Table 1: T-values and degrees of freedom belonging to the independent samples T-tests comparing WT to $\mathrm{KO}$ on each behavioral level of the shock sensitivity test, for PDE4D and PDE4B animals. No significant T-values were found.

\begin{tabular}{|c|c|c|c|c|}
\hline & PDE4-D & & PDE4-B & \\
\hline & $t$-values & $d f$ & $t$-values & $d f$ \\
\hline Flinching & -1.00 & 26 & -0.85 & 14 \\
\hline Running/Jumping & -0.74 & 24 & 0.08 & 14 \\
\hline Vocalizing & 0.56 & 26 & 0.31 & 14 \\
\hline
\end{tabular}
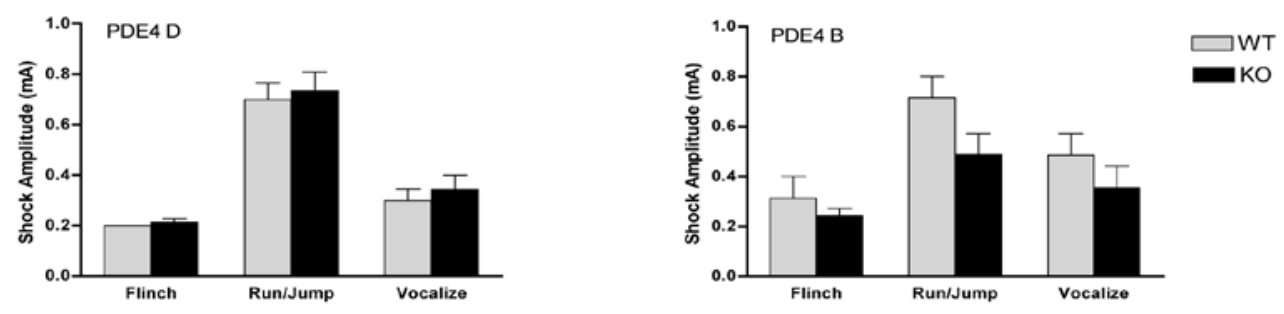

Figure 5: Sensitivity to the foot shock for PDE4-D and PDE4-B animals. The bars indicate the average required shock amplitude to generate flinching, running/jumping, or vocalizing behavior. Wild-types were compared to knock-outs for both PDE4-D (left) and PDE4-B (right) animals. 
No significant differences between knock-outs and wild-types were observed for either the PDE4-D or the PDE4-B mice (Figure 6) in the acquisition phase of spatial navigation. Post hoc Bonferroni tests revealed a significantly longer path length on day $1(P<0.001)$ compared to days $2(t=5.656), 3(t=4.667)$, and $4(t=4.221)$ in the PDE4-B mice. Post hoc tests also revealed a significantly longer path length on day $1(P<0.001)$ compared to days 3 $(t=6.3646)$ and $4(t=5.807)$ in the PDE4-D mice.
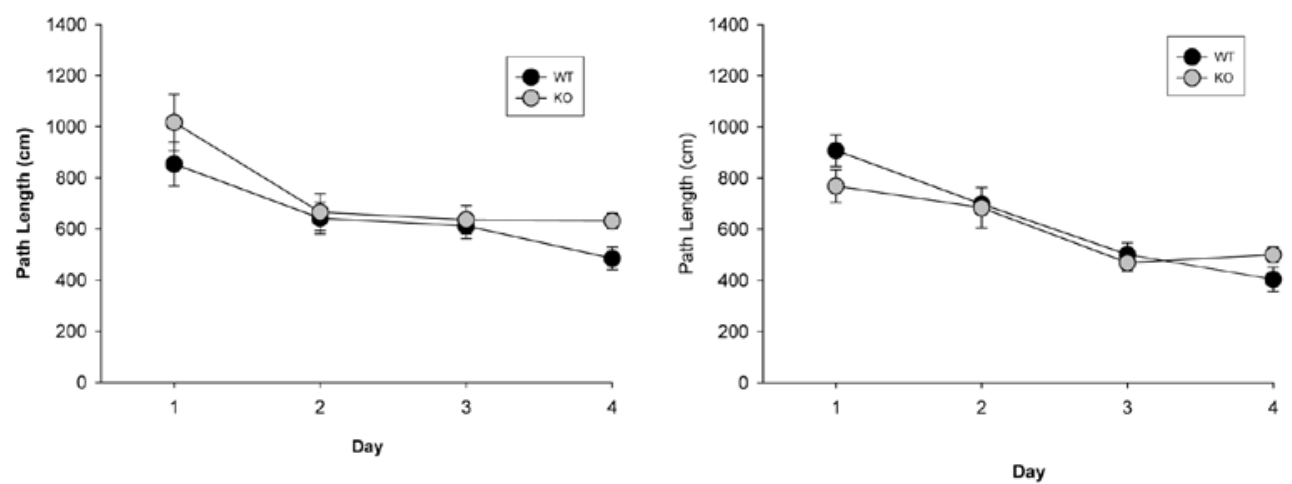

Figure 6: Acquisition of spatial navigation in Morris water maze for PDE4-D and PDE4-B animals. Wild-types were compared to knockouts for both PDE4-D (left) and PDE4-B (right) animals.

In the probe trials on day 3 and 5 , there were no significant differences in percent distance in zone in the PDE4-D (Figure 7). PDE4-B mice on the day 3 probe trial showed a significantly higher percent distance traveled in the target (North) quadrant compared to all other quadrants. Post-hoc tests revealed that percent total distance spent in the North quadrant for PDE4-B knock-outs was significantly higher than the South $(\mathrm{t}=5.907$, $P<0.001)$, East ( $\mathrm{t}=3.664, P<0.05)$, and West $(\mathrm{t}=3.664, P<0.01)$, and for PDE4-B wild-types was significantly higher than the South $(\mathrm{t}=6.161, P<0.001)$, East $(\mathrm{t}=4.595, P<0.001)$, and West ( $\mathrm{t}=3.427, P<0.01$ ). PDE4-B knock-out and wild-type mice did not differ within zone, between genotype in the day 3 probe trial. There were no significant differences observed for PDE4B mice on the day 5 probe trial.

In reversal learning, PDE4-D mice did not show significant differences in learning across days or genotype (Figure 8). PDE4-B mice showed a significant decrease in path length across day in reversal learning ( $t=4.288, P<0.001$ ) and there were significant differences in path length between PDE4-B knock-out and wild-type mice on day 2 ( $\mathrm{t}=2.464, P<0.05)$. 

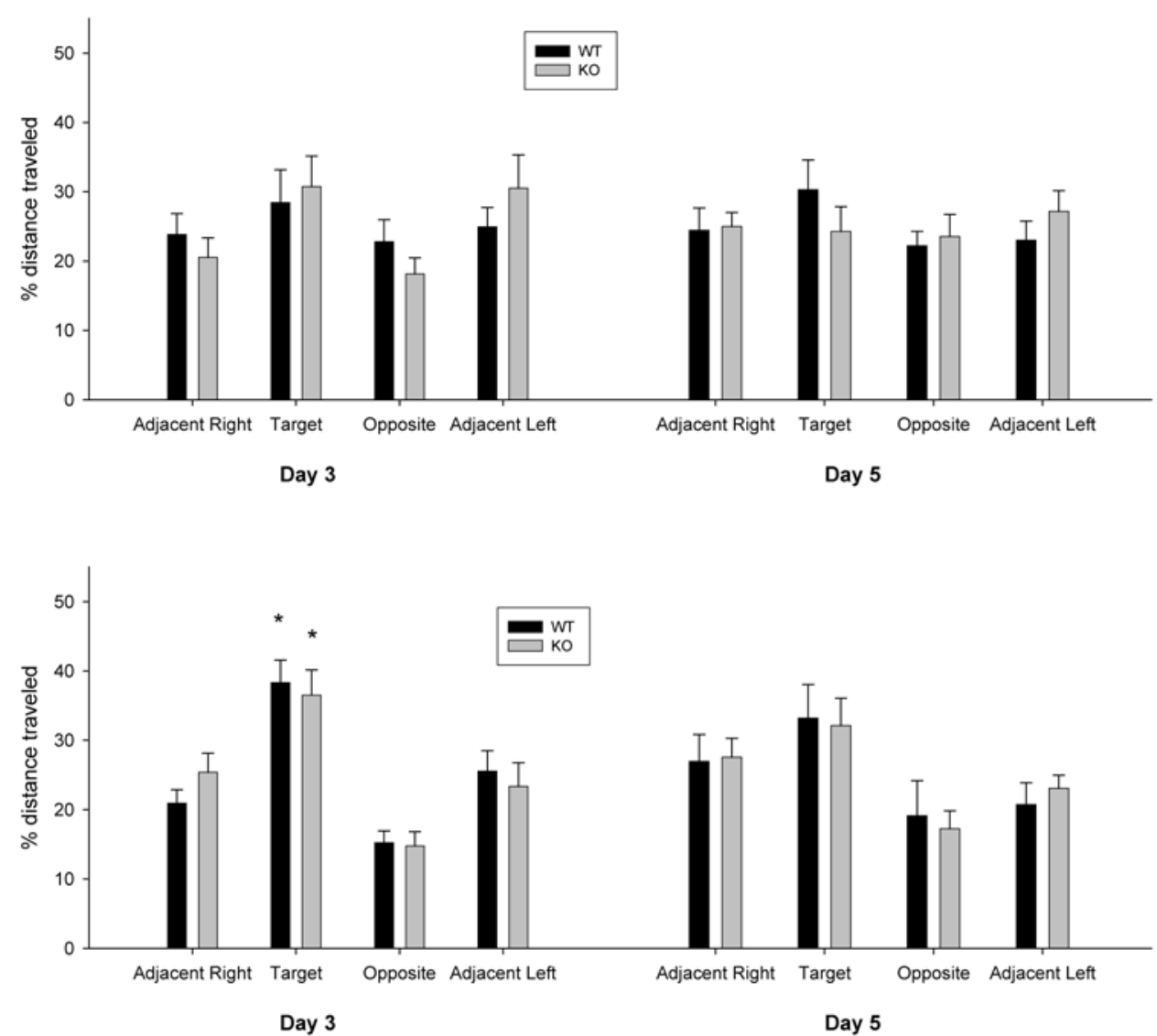

Figure 7: Probe trial of spatial navigation in Morris water maze for PDE4-D and PDE4-B animals. Wild-types were compared to knock-outs for both PDE4-D (top) and PDE4-B (bottom) animals.
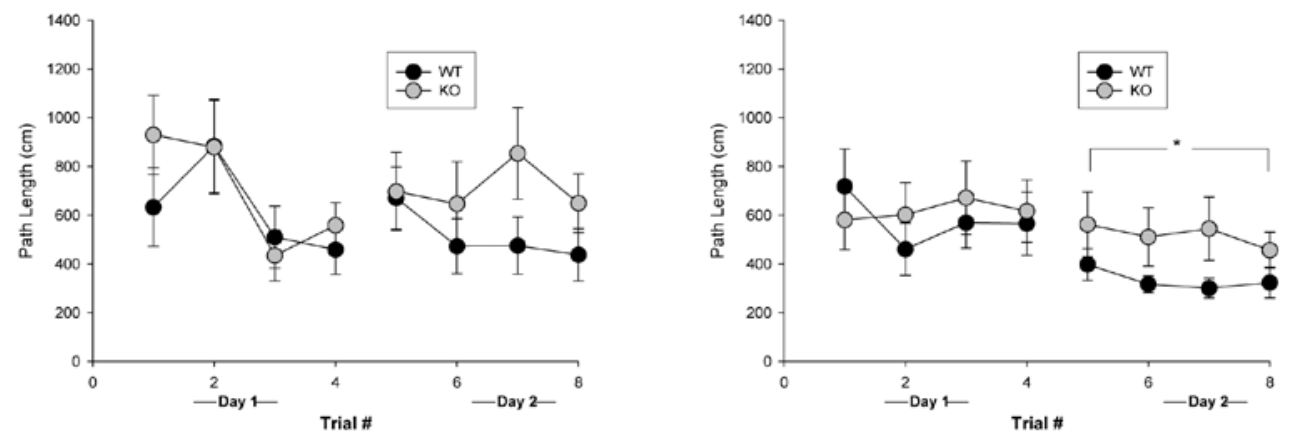

Figure 8: Reversal trial of spatial navigation in Morris water maze for PDE4-D and PDE4-B animals. Wild-types were compared to knockouts for both PDE4-D (left) and PDE4-B (right) animals. 
In cued navigation, both PDE4-D (Figure 9) and PDE4-B showed decreasing path lengths to reach the platform across trials and no differences were observed between knock-out and wildtype mice.

No significant differences between knock-outs and wild-types were observed for either PDE4D or PDE4-B mice in the learning capacity test. Between PDE4-D and PDE4-B mice, there were no significant differences in trials to criterion (Figure 10) or number of platforms experienced.
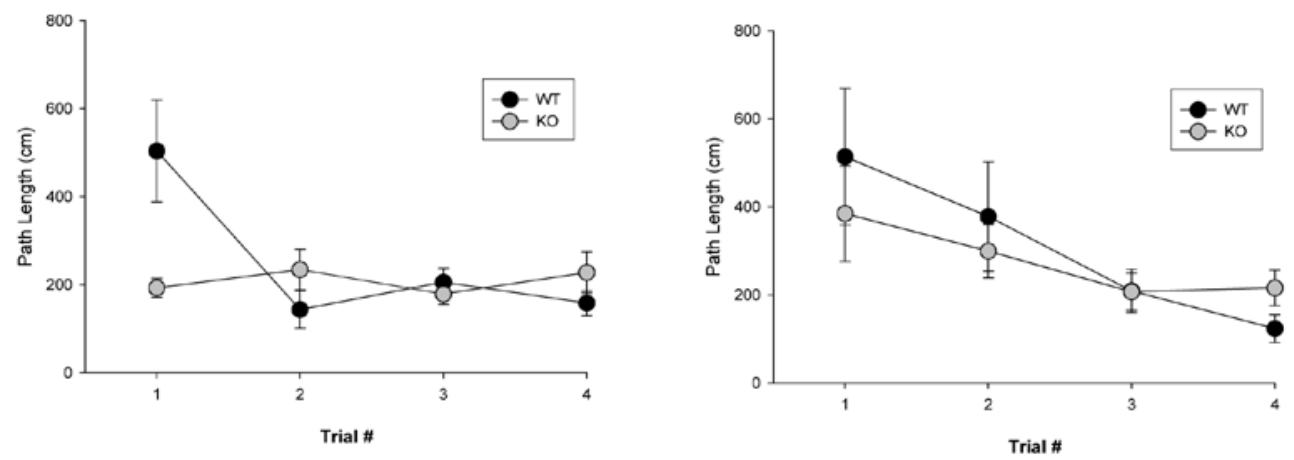

Figure 9: Cued navigation in Morris water maze for PDE4-D and PDE4-B animals. Wild-types were compared to knock-outs for both PDE4D (left) and PDE4-B (right) animals.
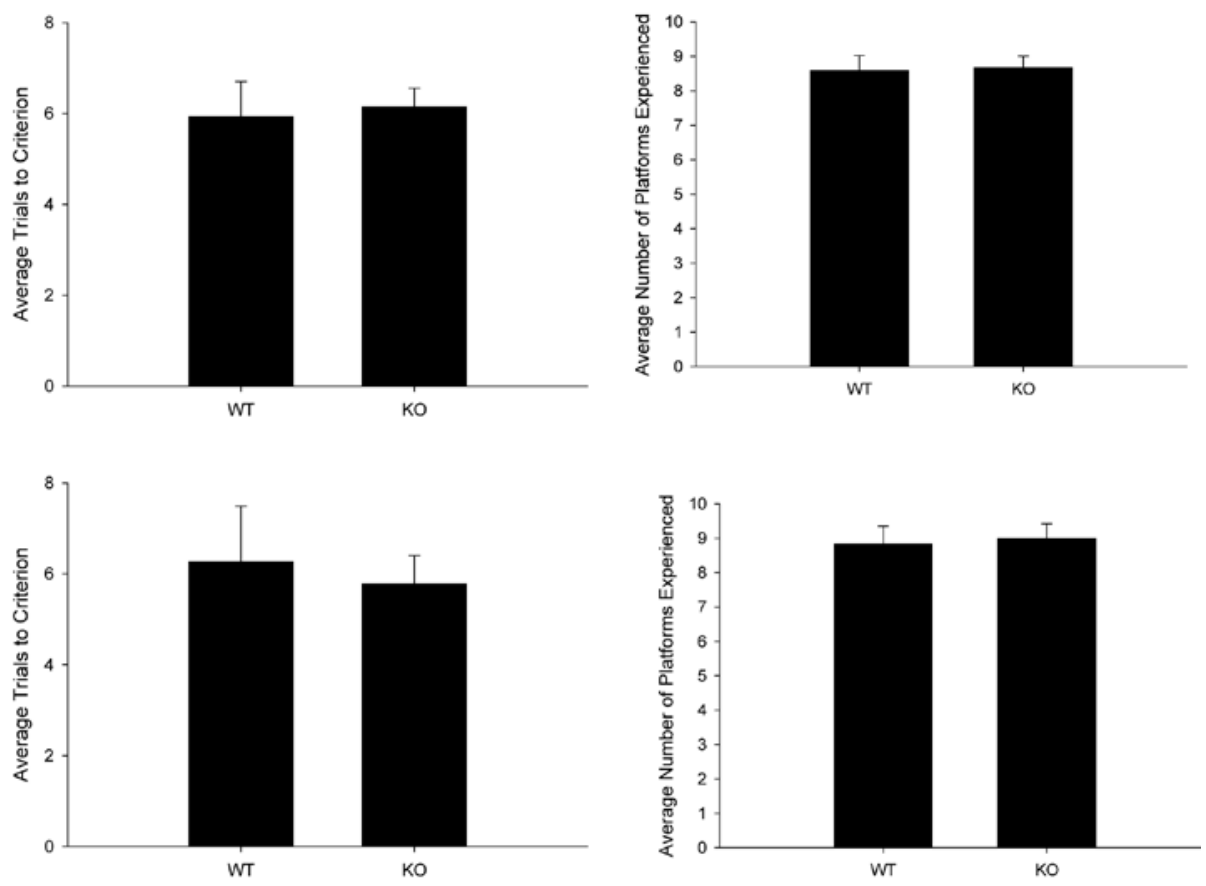

Figure 10: Learning capacity test in Morris water maze for PDE4-D and PDE4-B animals. Wild-types were compared to knockouts in average trials to criterion (left) and total number of platforms experienced (right) in PDE4-D (top) and PDE4-B (bottom) animals. 


\section{Discussion}

In the present study we characterized the effects on cognition of two specific PDE4 isoforms (PDE4-D and PDE4-B). PDE4 knockout mice were behaviorally tested in the context and cue test of a fear conditioning task and in a water maze task. In the fear conditioning paradigm found a shock dependant increase of freezing behavior in the context and cue test. Wild-type animals of both PDE4-B and PDE4-D strains learned to make an association between the delivered foot shock and the testing environment (context learning). In addition, the animals associated the tone to the aversive foot shock in the altered context condition (cue learning). These two (context and cue) forms of associative learning have shown to have different underlying neuronal mechanisms (LeDoux 2000). Lesions of the amygdala interfered with the conditioning of fear responses to both the cue and the context, whereas lesions of the hippocampus interfered with conditioning to the context but not to the cue. These findings suggest an associative role for the amygdala and a sensory relay role for the hippocampus in fear conditioning (Phillips and LeDoux 1992).

In the Morris water maze, a hippocampus-dependent task, both strains were able to learn the platform location. PDE4-D and PDE4-B mice showed a decrease in path length over acquisition trials indicating successful spatial navigation. There were no differences in path length in acquisition between knock-outs and wild-types in either PDE4-D or PDE4-B mice. In the probe trial on day 3 , a short-term spatial memory test, both knock-out and wild-type PDE4-B mice showed a preference for the target quadrant over all other quadrants, whereas the PDE4D mice showed equal preference for all quadrants. In reversal learning trials, PDE4-D mice did not show an improvement in spatial navigation over time. While the PDE4-B mice showed an overall improvement in navigation in reversal learning, this effect was largely driven by a significant decrease in path length for the wild-type mice. Within the second day of reversal learning, PDE4-B knock-out mice had significantly longer path lengths compared to wild-type mice. In the learning capacity test, both PDE4-D and PDE4-B mice demonstrated a similar number of trials to reach criterion and experienced the same average number of platforms.

The localization of PDE4-D and PDE4-B mRNA has been extensively described for many species including human, monkey and rat, however, to our knowledge, PDE4 isoform localization in the brain of mice has not been described yet (Perez-Torres et al. 2000). According to Perrez-Torres et al. (2000), PDE4-D mRNA is more abundant than PDE4-B mRNA in CA1, CA2 and CA3 areas of the hippocampus and in the granule cell layer of the dendate gyrus in rats. In addition, more mRNA activation was observed in the entorhinal and perirhinal cortex for PDE4-D than for PDE4-B. In contrast, PDE4-B mRNA was observed more in the caudate nucleus, putamen and nucleus accumbens. In the amygdaloid complex, PDE4-D mRNA was observed more in the bed nucleus of the accessory tract and the anterior cortical amygdaloid nucleus whereas PDE4-B mRNA was observed more in the basolateral amygdaloid nucleus (Perez-Torres et al. 2000). 
Neurons of the lateral amygdala show synaptic LTP and this may be the site for long term memory in cue fear conditioning. Increases in spike firing in the LA after fear conditioning are CS dependent, since unpaired US-CS (i.e. only the tone) showed extinction of fear responses (Maren and Quirk 2004). The PDE4-B isoform is more pronounced in the lateral amygdala areas than the PDE4-D isoform (as described above). However, no effects were observed after isoform knock-out on the cue-test in either of the strains. Since the hippocampus is believed to encode and process contextual cues in the fear conditioning task (Phillips and LeDoux 1992), this may indicate that the observed impairment might be originated in hippocampal areas, whereas the amygdala remains unaffected.

Moreover when tested in a short term memory version of the FC task with a 1 h delay between training and testing, no differences between genotypes were observed neither in the context version nor the cue version of the task. Thus, PDE4-D KO mice were impaired on long term memory but not on short term memory in context fear conditioning. Furthermore, for both context and cue test, PDE4-B animals learned the associations to the foot shock and no differences between genotypes were observed on long-term or short-term fear conditioning. The short-term memory task shows that the animals did acquire the task and that there were no baseline differences between the genotypes in the ability to learn the task.

A possibility was that the observed differences between genotypes in the PDE4-D mice were caused by differences in baseline activity levels or differences in shock perception. However, a loco-motor analysis showed that there were no differences between knock-out and wildtype mice in general activity measures. Moreover, no differences were observed between the genotypes in the reaction to the foot shocks. Thus, differences between WT mice and KO mice could not be explained by differences in loco-motor activity or shock perception.

When comparing the PDE4-D and PDE4-B animals on long term fear conditioning, it was observed that the PDE4-B wild-type animals had lower freezing scores than the PDE4-D wild-type mice. In the PDE4-B mice we did not see impairment after training with a $0.4 \mathrm{~mA}$ shock. Also, in the LMA experiment it was observed that PDE4-D animals were less active then PDE4-B animals, this might explain the higher baseline freezing levels between the wild-types of both strains. The reduced activity of PDE4-D mice as compared to PDE4-B's might be explained by developmental differences. For example, PDE4-D knockout mice have lower birth weights than wild-type littermates. From the above described results it might be concluded that PDE4-B and -D isoforms are differently involved in memory for FC. While PDE4-D knock-out mice show impairment in long term memory in the fear conditioning task the PDE4-B KO seem unaffected by the missing gene. The PDE4-D enzyme seems to influence processes in the long term acquisition of context memory in the FC paradigm.

Earlier pharmacological studies with PDE4 inhibitors showed memory improvement in several behavioral tasks in rats and mice (Gong et al. 2004; Imanishi et al. 1997; Rutten et al. 
2006a; Zhang et al. 2005). Inhibition of PDE4 causes elevation of cAMP and this is believed to improve LTP and long term memory via the CAMP/PKA/CREB pathway. Therefore we expected PDE4 KO to perform better than WT animals. However, this was not the case, PDE4-D knock-out mice even showed memory impairment in the fear conditioning task. Unpublished results have demonstrated LTP in PDE4-D knock-out mice and LTD in PDE4B knock-out mice. How to explain the observed impairment for the PDE4-D KOs remains speculative. A possible explanation could be that developmental changes occur in these mice that cause the deficit. These knock-out mice show lower birth weights as compared with wild-type littermates. Another explanation could be that adaptive changes to the missing enzyme have occurred in the brain and as a result baseline enzyme and neurotransmitter levels are altered. Furthermore, knock-out of the PDE4-D gene may cause an up-regulation of other PDEs that result in impaired fear conditioning performance. Due to these developmental differences of PDE4-D knockout mice no clear conclusions can be drawn at this point. Ongoing studies with specific local gene-silencing techniques rule out these developmental deficits and will provide more isoform specific information on the influence of PDE4 in depression and cognition.

Since no effects were observed in PDE4-B knock-out animals a specific role for the PDE4-D gene in cognition might be expected. A previous experiment with these PDE4-D knock-out mice showed an antidepressant-like effect for these animals (Zhang et al. 2002), however cognition was not assessed in this study. The present study for the first time investigated the effects of PDE4-D and PDE4-B knockout on hippocampus and amygdala dependant cognitive behavior.

Finally, inhibition of PDE4, for example by the PDE4 inhibitor rolipram, has shown to have pro-cognitive and antidepressive effects in several behavioral models (Blokland et al. 2006, in press; Mizokawa et al. 1988; Overstreet et al. 1989; Rose et al. 2005). However, severe side effects, such as emesis, have always been a dose limiting factor for clinical use of rolipram as an antidepressant or cognitive enhancer (Dyke and Montana 2002; Hebenstreit et al. 1989; Norman et al. 1992a; Overstreet et al. 1989). The PDE4-D isoform has been described to be involved in emesis, one of the dose-limiting factors in treatment with PDE4 inhibitors (Robichaud et al. 2002). However, mice deficient in other PDE4 isoforms have not been tested. Thus, targeting specific PDE4 isoforms could reduce the limiting side effects of the presently available PDE4 inhibitors and dissociate between side effects and procognitive or antidepressant effects. To further elucidate the role of the different subtypes of PDE4 genes in cognition and to further comprehend the present results and apply them to pro-cognitive drug development more specific PDE4 isoform studies are required. 


\section{References}

Ahi J, Radulovic J, Spiess J (2004) The role of hippocampal signaling cascades in consolidation of fear memory. Behav. Brain. Res. 149: 17-31

Bailey CH, Bartsch D, Kandel ER (1996) Toward a molecular definition of long-term memory storage. Proc. Natl. Acad. Sci. USA 93: 13445-52

Barco A, Pittenger C, Kandel ER (2003) CREB, memory enhancement and the treatment of memory disorders: promises, pitfalls and prospects. Expert. Opin. Ther. Targets. 7: 101-14

Bernabeu R, Bevilaqua L, Ardenghi P, Bromberg E, Schmitz P, Bianchin M, Izquierdo I, Medina JH (1997) Involvement of hippocampal cAMP/cAMP-dependent protein kinase signaling pathways in a late memory consolidation phase of aversively motivated learning in rats. Proc. Natl. Acad. Sci. USA 94: 7041-6

Bernabeu R, Schmitz P, Faillace MP, Izquierdo I, Medina JH (1996) Hippocampal cGMP and cAMP are differentially involved in memory processing of inhibitory avoidance learning. Neuroreport 7: 585-588

Blokland A, Schreiber R, Prickaerts J (2006, in press) Improving Memory: A role for Phosphodiesterases. Curr. Pharm. Des.

Boess FG, Hendrix M, van der Staay FJ, Erb C, Schreiber R, van Staveren W, de Vente J, Prickaerts J, Blokland A, Koenig G (2004) Inhibition of phosphodiesterase 2 increases neuronal cGMP, synaptic plasticity and memory performance. Neuropharmacology 47: 1081-92

Bourtchouladze R, Lidge R, Catapano R, Stanley J, Gossweiler S, Romashko D, Scott R, Tully T (2003) A mouse model of Rubinstein-Taybi syndrome: defective long-term memory is ameliorated by inhibitors of phosphodiesterase 4. Proc. Natl. Acad. Sci. U S A 100: 10518-22

Comery TA, Martone RL, Aschmies S, Atchison KP, Diamantidis G, Gong X, Zhou H, Kreft AF, Pangalos MN, Sonnenberg-Reines J, Jacobsen JS, Marquis KL (2005) Acute gamma-secretase inhibition improves contextual fear conditioning in the Tg2576 mouse model of Alzheimer's disease. 25: 8898-902

Dyke HJ, Montana JG (2002) Update on the therapeutic potential of PDE4 inhibitors. Expert Opin. Investig. Drugs. 11: 1-13

Frey U, Huang YY, Kandel ER (1993) Effects of cAMP simulate a late stage of LTP in hippocampal CA1 neurons. Science 260: 1661-4

Gong B, Vitolo OV, Trinchese F, Liu S, Shelanski M, Arancio O (2004) Persistent improvement in synaptic and cognitive functions in an Alzheimer mouse model after rolipram treatment. J. Clin. Invest. 114: 1624-1634

Hebenstreit GF, Fellerer K, Fichte K, Fischer G, Geyer N, Meya U, Sastre-y-Hernandez M, Schony W, Schratzer M, Soukop W, et al. (1989) Rolipram in major depressive disorder: results of a double-blind comparative study with imipramine. Pharmacopsychiatry 22: 156-160

Imanishi T, Sawa A, Ichimaru Y, Miyashiro M, Kato S, Yamamoto T, Ueki S (1997) Ameliorating effects of rolipram on experimentally induced impairments of learning and memory in rodents. Eur. J. Pharmacol. 321 273-278

Jin SL, Latour AM, Conti M (2005) Generation of PDE4 knockout mice by gene targeting. Methods Mol. Biol. 307: $191-210$

LeDoux JE (2000) Emotion circuits in the brain. Annu. Rev. Neurosci. 23: 155-84

Maren S, Quirk GJ (2004) Neuronal signalling of fear memory. Nat. Rev. Neurosci. 5: 844-52

Mizokawa T, Kimura K, Ikoma Y, Hara K, Oshino N, Yamamoto T, Ueki S (1988) The effect of a selective phosphodiesterase inhibitor, rolipram, on muricide in olfactory bulbectomized rats. Jpn. J. Pharmacol. 48: 357-364

Norman TR, Judd FK, Burrows GD (1992) New pharmacological approaches to the management of depression: from theory to clinical practice. Aust. N. Z. J. Psychiatry 26: 73-81

Overstreet DH, Double K, Schiller GD (1989) Antidepressant effects of rolipram in a genetic animal model of depression: cholinergic supersensitivity and weight gain. Pharmacol. Biochem. Behav. 34: 691-696

Perez-Torres S, Miro X, Palacios JM, Cortes R, Puigdomenech P, Mengod G (2000) Phosphodiesterase type 4 isozymes expression in human brain examined by in situ hybridization histochemistry and[3H]rolipram binding autoradiography. Comparison with monkey and rat brain. J. Chem. Neuroanat. 20: 349-74

Phillips RG, LeDoux JE (1992) Differential contribution of amygdala and hippocampus to cued and contextual fear conditioning. Behav. Neurosci. 106: 274-285 
Prickaerts J, de Vente J, Honig W, Steinbusch HW, Blokland A (2002) cGMP, but not cAMP, in rat hippocampus is involved in early stages of object memory consolidation. Eur. J. Pharmacol. 436: 83-87

Prickaerts J, Sik A, van Staveren WC, Koopmans G, Steinbusch HW, van der Staay FJ, de Vente J, Blokland A (2004) Phosphodiesterase type 5 inhibition improves early memory consolidation of object information. Neurochem. Int. 45: 915-928

Robichaud A, Savoie C, Stamatiou PB, Lachance N, Jolicoeur P, Rasori R, Chan CC (2002) Assessing the emetic potential of PDE4 inhibitors in rats. Br. J. Pharmacol. 135: 113-118

Rose GM, Hopper A, De Vivo M, Tehim A (2005) Phosphodiesterase inhibitors for cognitive enhancement. Curr. Pharm. Des. 11: 3329-34

Rutten K, Prickaerts J, Blokland A (2006) Rolipram reverses scopolamine-induced and time-dependent memory deficits in object recognition by different mechanisms of action. Neurobiol. Learn. Mem. 85: 132-8

Zhang HT, Crissman AM, Dorairaj NR, Chandler LJ, O'Donnell JM (2000) Inhibition of cyclic AMP phosphodiesterase (PDE4) reverses memory deficits associated with NMDA receptor antagonism. Neuropsychopharmacology 23: 198-204

Zhang HT, Huang Y, Jin SL, Frith SA, Suvarna N, Conti M, O’Donnell JM (2002) Antidepressant-like profile and reduced sensitivity to rolipram in mice deficient in the PDE4D phosphodiesterase enzyme. Neuropsychopharmacology 27: 587-95

Zhang HT, Huang Y, Suvarna NU, Deng C, Crissman AM, Hopper AT, De Vivo M, Rose GM, O’Donnell J M (2005) Effects of the novel PDE4 inhibitors MEM1018 and MEM1091 on memory in the radial-arm maze and inhibitory avoidance tests in rats. Psychopharmacology (Berl)

Zhang HT, Zhao Y, Huang Y, Dorairaj NR, Chandler LJ, O'Donnell JM (2004) Inhibition of the phosphodiesterase 4 (PDE4) enzyme reverses memory deficits produced by infusion of the MEK inhibitor U0126 into the CA1 subregion of the rat hippocampus. Neuropsychopharmacology 29: 1432-9 


\section{SELECTIVE PDE INHIBITORS SILDENAFIL AND ROLIPRAM IMPROVE OBJECT RETRIEVAL PERFORMANCE IN UNIMPAIRED ADULT CYNOMOLGUS MACAQUES}

K. Rutten, J. L. Basile, J. Prickaerts, A. Blokland, J. A. Vivian

Psychopharmacology (submitted)

Rationale: Selective phosphodiesterase (PDE) inhibitors have been shown to improve long-term memory in several rodent models of cognition. However, studies evaluating the effects of PDE inhibition on cognition in unimpaired primates are very scarce. OBJECTIVES: The present study investigates the effect of the PDE4 inhibitor rolipram and the PDE5 inhibitor sildenafil on object retrieval (OR) performance. OR is a prefrontal cortical mediated task, which is likely to capture attention and response inhibition. Materials and methods: Adult male cynomolgus macaques were trained in the OR task. The effects of rolipram $(0,0.003,0.01$ and $0.03 \mathrm{mg} / \mathrm{kg}$, i.m.) and sildenafil (0, 0.3, 1 and $3 \mathrm{mg} / \mathrm{kg}$, i.m.) treatment on the percentage correct first reaches, which is $50 \%$ correct in difficult trials, were investigated. Results: Rolipram dose-dependently increased correct first reaches during difficult trials, reaching significance at $0.01 \mathrm{mg} / \mathrm{kg}$ and maximal performance of $71 \%$ correct at the dose of $0.03 \mathrm{mg} / \mathrm{kg}$. Sildenafil dose-dependently increased correct first reaches during difficult trials, reaching significance at $1 \mathrm{mg} / \mathrm{kg}$. At the highest dose tested ( $3 \mathrm{mg} / \mathrm{kg}$ ), correct reaches were increased to $73 \%$. Conclusions: Both rolipram and sildenafil significantly improved performance in the OR task. These findings complement and extend to the cognition-enhancing effects of cAMP and cGMP via PDE inhibition. However, the underlying mechanism of action and cellular pathways remain elusive. 


\section{Introduction}

Second messenger cyclic nucleotides, i.e cyclic adenosine monophosphate (cAMP) and cyclic guanosine monophosphate (cGMP), have been strongly implicated in processes of synaptic long term potentiation (LTP) (Frey et al. 1993; Zhuo et al. 1994) and have cognition enhancing properties (Bernabeu et al. 1996; Blokland et al. 2006b; Prickaerts et al. 2005). cAMP and cGMP are hydrolyzed by phosphodiesterase (PDE) enzymes. Cognition enhancing effects of cAMP and cGMP are widely studied by administration of PDE inhibitors (PDE-Is) in animal models of cognition. In this field, research has focused on PDE4 and PDE5 inhibitors (Blokland et al. 2006b; Rose et al. 2005; Rutten et al. 2006a), and more recently PDE2 (Boess et al. 2004; Rutten et al. 2007b) and PDE10 (Rodefer et al. 2005) inhibitors. Rodent studies have shown that inhibition of PDE2, 4 and 5 can improve memory in the object recognition task (Boess et al. 2004; Prickaerts et al. 2004; Rutten et al. 2007b). Moreover, the cAMPselective PDE4-I rolipram is an effective performance enhancer in the passive avoidance task (Egawa et al. 1997; Imanishi et al. 1997), fear conditioning test (Barad et al. 1998) and radial arm maze (Zhang and O’Donnell 2000).

The cyclic-GMP (cGMP) selective PDE5-I sildenafil has been shown to not only effectively enhance performance in the object recognition task, but also in the T-Maze and spatial plus maze (Devan et al. 2006; Devan et al. 2004; Patil et al. 2006; Prickaerts et al. 2004). In addition, sildenafil improved object recognition memory in mice (Rutten et al. 2005) and another PDE5I, zaprinast, improved performance in a passive avoidance task in neonate chicks (Campbell and Edwards 2006). Human experiments with PDE5-Is in memory tasks are being performed and also preclinical trials with PDE4-Is are ongoing. PDE-Is can be seen as a an effective target for cognitive enhancement in several neuropathological diseases, such as Alzheimer's disease, Parkinson's disease, and amnesia (Blokland et al. 2006b; Weishaar et al. 1985a).

The current literature of PDE inhibition in cognition has mainly focused on learning and memory functioning in rodents. However, the effects of PDE-I on prefrontal, executive functions have not been evaluated previously. The present study shifts attention from rodents to non-human primates and focuses on possible cognition-enhancing effects of PDE inhibition in a task of prefrontal behavior, namely the object retrieval task. Object retrieval in primates (OR; also known in the literature as the object detour task) is a prefrontal cortical mediated behavior, which is likely to capture attention, response inhibition and planning (executive function) (Diamond et al. 1989). Successful completion of the OR task requires various hypothetical steps, including: resolution of contradictory signals conveyed by visual and tactile inputs, suppression of the incorrect signal, representation of the incorrect approach stored in a short term memory system that may be retrieved, and expression in the 'detour' test of an innate species-characteristic tendency of perseveration toward a sustained sensory stimulation. (Lipina and Colombo 2001). Deficits in motor planning and in the ability to inhibit certain behavioral responses have been demonstrated in humans with Parkinson's disease, in patients with frontal lobe lesions and in children with attention deficit hyperactivity disorder (ADHD) (Schneider and Roeltgen 1993). Furthermore, deficits 
in OR tasks have been documented in primates after treatment with MPTP (Schneider and Roeltgen 1993; Taylor et al. 1990a; Taylor et al. 1990b), phencyclidine (PCP) (Jentsch et al. 2000; Jentsch et al. 1999a; Jentsch et al. 1999b), and after excitotoxic lesioning with quinolinic acid of the prefrontal cortex (Roitberg et al. 2002). The effect of PDE-Is in the OR have, to our knowledge, never been evaluated before in unimpaired primates. Of note, Ramos et al. (2003) found improved spatial working memory performance of the prefrontal cortex after treatment with rolipram in young Rhesus monkeys and performance impairment in aged Rhesus monkeys in a spatial delayed response task.

Based on previous studies with PDE-Is in rodents, the objective of the current study was to characterize the potential cognition-enhancing effects of PDE-Is in a frontally-mediated behavior capturing executive function. We hypothesized that not only memory but also executive functions and response inhibition might be improved by inhibition of PDEs. The PDE4 enzyme is omnipresent throughout the brain and PDE5 is found in the hippocampus, throughout the cortex and in the cerebellum (See van Staveren et al. 2004). Thus, elevation of cAMP and cGMP in the prefrontal cortex, through PDE4-Is or PDE5-Is respectively, could therefore be a possible way to improve cognitive performance in a prefrontal task. The present study investigated the pro-cognitive effects of two selective PDE-Is in non-human primates. The effects of sildenafil (PDE5-I) and rolipram (PDE4-I) were assessed in the OR task in unimpaired adult cynomolgus macaques.

\section{Methods}

\section{Subjects}

A total of 14 adult male cynomolgus macaques (Macaca fascicularis) were housed in samesex pairs in a colony room maintained at $21 \pm 2^{\circ} \mathrm{C}, 40 \pm 10 \%$ humidity, and on a normal $12 \mathrm{~h}$ light/dark cycle (lights on $7.00 \mathrm{am}$ ). Food (Purina High Protein \#5045) and water were available ad lib. All experimental procedures were approved by the Institutional Animal Care and Use Committee (IACUC) of Roche Palo Alto and were in accordance with NIH guidelines.

\section{Object retrieval task}

The object retrieval task has been previously described by Diamond et al. (1989), and revised by Basile \& Vivian (publication in prep). Briefly, this task requires a monkey to reach into a clear acrylic box (dimensions: $5 \mathrm{~cm} \times 5 \mathrm{~cm} \times 5 \mathrm{~cm}$ ) with one open side, to retrieve a food treat (cubes of apple or pear $\left(1-2 \mathrm{~cm}^{2}\right)$ ). The box was positioned in front of the monkey and outside of the home cage, with the open side facing left, right, or centered (i.e., in front of) relative to the monkey. Food treats were placed on the outer edge, inner edge, or deep within the box. A test session consisted of 17 trials with 9 "easy" food retrievals (i.e., placement of the food reward on the inner or outer edges of the box, or when the opening is centered relative to the monkey) and 8 "difficult" food retrievals (i.e., placement of the food reward deep 
within the box and the open side facing left or right, see Figure 1). The order of presentation never varied (Table 1), and trials were terminated if there were no reaches within 3-min. Note that there were no contingencies for incorrect reaches (i.e., monkeys typically acquired the treat after the incorrect reach) or dropped treats, and the box was cleaned diligently between trials to minimize barrier cues which could influence the task and subsequent task performance. After an initial period (1 week) to acclimate the monkeys to the apparatus, and familiarize them with the procedures, tests were conducted twice a week.

Table 1: Primate Object Retrieval: Trial Order

\begin{tabular}{ccc}
\hline Trial \# & Description & Level \\
\hline 1 & LOS - Line of Sight & Easy \\
3 & LOS - Line of Sight & Easy \\
4 & RO - Right Outside & Easy \\
5 & RD - Right Deep & Difficult \\
6 & RO - Right Outside & Easy \\
7 & RI - Right Inside & Easy \\
8 & RD - Right Deep & Difficult \\
9 & LO - Left Outside & Easy \\
10 & LD - Left Deep & Difficult \\
11 & LO - Left Outside & Easy \\
12 & LI - Left Inside & Easy \\
13 & LD - Left Deep & Difficult \\
14 & LD - Left Deep & Difficult \\
15 & RD - Right Deep & Difficult \\
16 & LD - Left Deep & Difficult \\
17 & RD - Right Deep & Difficult
\end{tabular}

\section{Drugs}

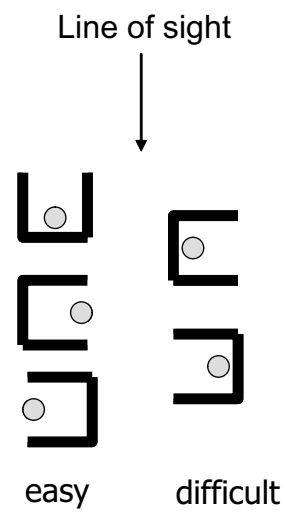

Figure 1: A schematic overview of possible trials in the object retrieval (detour reaching) task. The left panel shows easy trials and the right panel shows difficult trials. 
Sildenafil (0.3, 1 and 3 mg/kg; Sequoia Research Products Limited, Pangbourne, UK) and rolipram (0.003, 0.01, 0.03 and $0.1 \mathrm{mg} / \mathrm{kg}$; Sigma Chemicals, St Louis, MO) were prepared fresh daily in a suspension of $10 \%$ cremaphore/ $90 \%$ saline, and administered 60 or 30 min prior to testing, respectively. All drugs were administered intramuscular (i.m.) in a volume of $0.1 \mathrm{ml} / \mathrm{kg}$.

\section{Data Analysis}

The mean percent correct first reaches for easy and difficult food retrievals were analyzed with a one-factor (DOSE) repeated measures analysis of variance (ANOVA). When significant effects were demonstrated, a post-hoc Dunnett analysis was performed, comparing dose conditions to vehicle performance. For all tests, the significance level was 0.05, two-tailed.

\section{Results}

In object retrieval test sessions involving vehicle administration, monkeys readily reached for the food treats, successfully acquiring the treat on the first reach $100 \pm 0 \%$ during easy trials, and $52 \pm 3 \%$ during difficult trials. Over the course of the experiment ( 2 months), there were no changes in vehicle performance.

The PDE-4 inhibitor rolipram (0.003-0.1 mg/kg, i.m.) dose-dependently increased correct first reaches during difficult trials $[\mathrm{F}(3,55)=13.5, p<0.05]$, reaching significance at $0.01 \mathrm{mg} / \mathrm{kg}$, i.e. different from vehicle (Figure $2 \mathrm{a}$ ). At $0.03 \mathrm{mg} / \mathrm{kg}$, the percentage correct first reaches were increased to $71 \pm 3 \%$. Note that at $0.1 \mathrm{mg} / \mathrm{kg}$ (data not shown), emesis was observed in all but two monkeys, these results were therefore excluded from analysis.

The PDE-5 inhibitor sildenafil (0.3-3 mg/kg, i.m.) dose-dependently increased correct first reaches during difficult trials $[\mathrm{F}(3,50)=8.6, p<0.05]$, reaching significance at $1 \mathrm{mg} / \mathrm{kg}$. At the highest dose tested ( $3 \mathrm{mg} / \mathrm{kg}$ ), correct reaches were increased to $73 \pm 3 \%$, and no untoward signs were observed (Figure $2 b$ ).
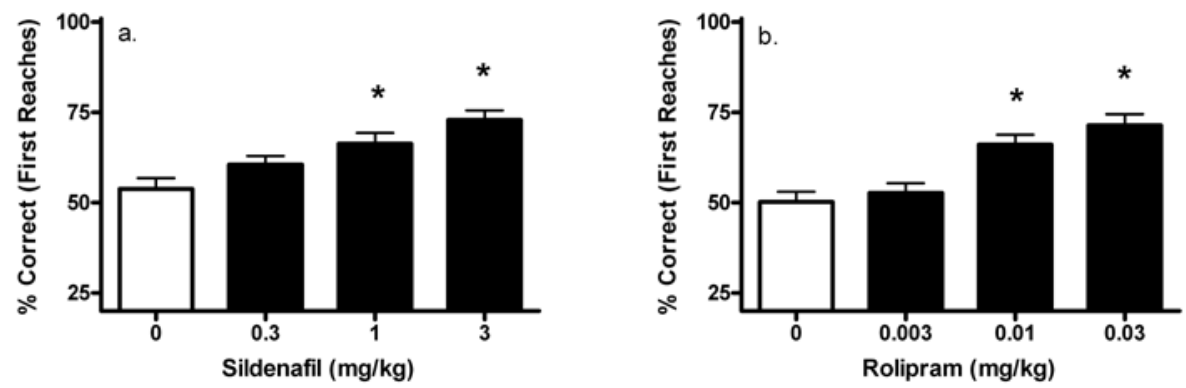

Figure 2: The effects of PDE-I on Object Retrieval (OR) performance (mean values and SEM).a) The effects of the PDE5 inhibitor sildenafil (a) and the PDE4 inhibitor rolipram (b) on the percentage correct first reaches on difficult trials in the OR task. Asterisks indicate significant differences from baseline $(\mathrm{P}<0.05)$ 
Neither rolipram nor sildenafil altered performance during the easy trials, with the exception of the high dose of rolipram $(0.1 \mathrm{mg} / \mathrm{kg})$, in which monkeys failed to perform the task (data not shown) because of emetic side-effects.

\section{Discussion}

The present study demonstrates performance-enhancing effects of two selective PDEIs on object retrieval in unimpaired monkeys. The object retrieval task is generally used as a measure for prefrontal functioning after induced damage to the frontal cortex or frontostriatal pathways. The prefrontal cortex and its dopaminergic and cholinergic innervation pathways are involved in attention processes, working memory processes, and response inhibition in rodents and primates. Thus, the current results complement and extend cognition-enhancing effects of PDE inhibition.

Previous studies have repeatedly shown that PDE-Is can have pro-cognitive effects in healthy unimpaired rodents. PDE4 inhibition improved long term memory in the object recognition task (Rutten et al. 2006a), in passive avoidance learning (Zhang et al. 2005), and fear conditioning (Barad et al. 1998). Furthermore, PDE4-Is have shown to be effective in numerous deficit models (for a review see Blokland et al. 2006b). Compared to PDE4 inhibition, the cognition enhancing effects of PDE5 inhibition have not been studied as extensively. However, a growing amount of studies have shown pro-cognitive effects of PDE5-Is in different species and various behavioral tasks. PDE5-Is improved cognitive performance in inhibitory and passive avoidance task (Baratti and Boccia 1999; Shafiei et al. 2006), elevated plus maze (Singh and Parle 2003), and object recognition (Prickaerts et al. 2005; Prickaerts et al. 2004; Prickaerts et al. 2002b; Rutten et al. 2005). In addition, a couple of studies have shown ameliorating effects of PDE5-Is in deficit models (Devan et al. 2006; Devan et al. 2004; Patil et al. 2006). The underlying mechanisms of PDE-Is and cognition enhancement are still elusive, but several possible pathways have been described (see below).

A possible mechanism of action for rolipram in cognition enhancement is the cAMP-Protein kinase A (PKA) pathway. This pathway was shown to enhance performance in hippocampal short-term memory tasks (Ahi et al. 2004; Bernabeu et al. 1997; Frey et al. 1993; Friedrich et al. 2004). A recent study showed that activation of the cAMP-PKA signaling pathway, through rolipram, improves spatial working memory in the prefrontal cortex in young rats (delayed alternation in a T-maze) and monkeys (special delayed response task) (Ramos et al. 2003).

In addition, the effects of rolipram on prefrontal functioning in the OR may be explained by its stimulatory effect on neurotransmission. Since rolipram is independent of a specific receptor system it is suggested that rolipram may ameliorate physiological abnormalities that occur secondary to alterations in dopaminergic, glutamatergic, serotonergic and/or adrenergic transmission (Maxwell et al. 2004; Rutten et al. 2007a). Both enhanced cholinergic turnover pre-synaptically and inhibition of cAMP degradation post-synaptically, could enhance cholinergic signaling and increase attention and behavioral performance (Imanishi et al. 1997). In addition, elevated cAMP levels are thought to excite noradrener- 
gic and dopaminergic neurotransmitter systems (Schoffelmeer et al. 1985), thus enhancing their availability, hence also enhancing synaptic transmission.

What is known about the possible mechanism underlying our observed pro-cognitive effects of sildenafil related to prefrontal cortex function? Current concepts on the working mechanism of cGMP and nitric oxide (NO) in strengthening synaptic contacts define a presynaptic effect of NO, in conjunction with the retrograde messenger role of NO (Garthwaite and Boulton 1995). NO activates soluble Guanylate Cyclase (sGC) pre-synaptically, which in turn catalyzes cGMP production and enhances neurotransmission (Bernabeu et al. 1996; Prickaerts et al. 1997; Son et al. 1998). The enhanced neurotransmission might be caused by cGMP-mediated Protein Kinase G (PKG) activation (Zhuo et al. 1994) or by stimulation of cGMP-gated ion channels (Zufall 1996). In addition, cGMP- PKG activation has also been suggested for long term memory enhancement in hippocampus dependent tasks via CREB activation (Lu and Hawkins 2002). Thus, PDE5-I can have an effect, via elevated cGMP levels, on memory processes either pre-synaptically (through the sGC/cGMP pathway) or post-synaptically (through the cGMP/PKG/CREB pathway). A very recent study by Matsumoto et al. (2006) suggested another pathway through which cGMP can influence cognitive processes. This study showed that the NO/cGMP pathway directly stimulates the cAMP/PKA/CREB pathway, which is known to be involved in long-term memory as well (Matsumoto et al. 2006). Thus, both cGMP and cAMP can activate the PKA/CREB cascade and induce long lasting changes in neuronal signaling and may thereby improve learning and memory.

Similar to rolipram, sildenafil is a drug that is not linked to specific neurotransmitter systems. Modulatory activity of sildenafil was suggested on central dopaminergic pathways and, possibly, on nitric oxide production (Ferrari et al. 2002). Hence, activation of cGMP may improve dopaminergic turnover and prefrontal functioning. Thus far, it remains unclear which of these above mentioned mechanisms are involved in the prefrontal cortex and how they explain cognition enhancement by inhibition of PDEs in the object retrieval task.

Of note, in aged monkeys and rats, rolipram decreased working memory performance of the prefrontal cortex (Arnsten et al. 2005; Ramos et al. 2003). The behavioral tasks used, i.e. delayed alternation in a T-maze for rats and delayed response task in Rhesus monkeys, rely heavily on working memory processes. The object retrieval task, used in the present study, does not involve working memory but requires attention and response inhibition (Diamond et al. 1989). Furthermore, the animals tested in the former studies were age impaired animals as compared to the adult unimpaired monkeys used in the present study. Our findings corroborate the findings by Ramos et al (2003) that rolipram tended to improve spatial working memory in the frontal cortex at a similar dose of rolipram $(10 \mu \mathrm{g} / \mathrm{kg})$ in young adult monkeys. However in aged monkeys rolipram impaired working memory performance and opposite profiles between the hippocampus and the prefrontal cortex were suggested with advancing age to explain these results: the prefrontal cortex showed indices of increase PKA activity, while the hippocampus exhibited evidence of decreased PKA activity (Ramos et al. 2003). 
Dopaminergic dysfunction in prefrontal cortex may subserve at least a component of the impaired object retrieval/detour performance in deficit models (Jentsch et al. 1999a). Moreover, serotonin depletions of the orbitofrontal cortex in the common marmoset result in deficits in the acquisition of the OR task (Walker et al. 2006). On one hand, the increase in neurotransmitter signaling by both elevation of cAMP and cGMP might be the underlying mechanism of the effects of PDE-I on OR performance. On the other hand, the cellular pathway theories of cAMP/PKA, sGC/cGMP or cGMP/PKG are considered very important mechanisms for learning and memory processes in the hippocampus and these could also be effective in prefrontal cortical areas.

Summarizing, the present study shifts the focus of PDE4 and 5 inhibition from a rodent hippocampal task to a primate prefrontal task and it showed that, in unimpaired adult monkeys, rolipram and sildenafil have pro-cognitive effects. Underlying mechanisms of action for these drugs remain to be further elucidated.

\section{References}

Ahi J, Radulovic J, Spiess J (2004) The role of hippocampal signaling cascades in consolidation of fear memory. Behav. Brain. Res. 149: 17-31

Arnsten AF, Ramos BP, Birnbaum SG, Taylor JR (2005) Protein kinase A as a therapeutic target for memory disorders: rationale and challenges. Trends. Mol. Med. 11: 121-8

Barad M, Bourtchouladze R, Winder DG, Golan H, Kandel E (1998) Rolipram, a type IV-specific phosphodiesterase inhibitor, facilitates the establishment of long-lasting long-term potentiation and improves memory. Proc. Natl. Acad. Sci. USA 95: 15020-15025

Baratti CM, Boccia MM (1999) Effects of sildenafil on long-term retention of an inhibitory avoidance response in mice. Behav. Pharmacol. 10: 731-737

Bernabeu R, Bevilaqua L, Ardenghi P, Bromberg E, Schmitz P, Bianchin M, Izquierdo I, Medina JH (1997) Involvement of hippocampal cAMP/cAMP-dependent protein kinase signaling pathways in a late memory consolidation phase of aversively motivated learning in rats. Proc. Natl. Acad. Sci. USA 94: 7041-6

Bernabeu R, Schmitz P, Faillace MP, Izquierdo I, Medina JH (1996) Hippocampal cGMP and cAMP are differentially involved in memory processing of inhibitory avoidance learning. Neuroreport 7: 585-588

Blokland A, Schreiber R, Prickaerts J (2006) Improving memory: a role for phosphodiesterases. Curr. Pharm. Des. 12: 2511-2523

Boess FG, Hendrix M, van der Staay FJ, Erb C, Schreiber R, van Staveren W, de Vente J, Prickaerts J, Blokland A, Koenig G (2004) Inhibition of phosphodiesterase 2 increases neuronal cGMP, synaptic plasticity and memory performance. Neuropharmacology 47: 1081-92

Campbell E, Edwards T (2006) Zaprinast consolidates long-term memory when administered to neonate chicks trained using a weakly reinforced single trial passive avoidance task. Behav. Brain. Res. 169: 181-5

Devan BD, Bowker JL, Duffy KB, Bharati IS, Jimenez M, Sierra-Mercado D, Jr., Nelson CM, Spangler EL, Ingram DK (2006) Phosphodiesterase inhibition by sildenafil citrate attenuates a maze learning impairment in rats induced by nitric oxide synthase inhibition. Psychopharmacology (Berl) 183: 439-45

Devan BD, Sierra-Mercado D, Jr., Jimenez M, Bowker JL, Duffy KB, Spangler EL, Ingram DK (2004) Phosphodiesterase inhibition by sildenafil citrate attenuates the learning impairment induced by blockade of cholinergic muscarinic receptors in rats. Pharmacol. Biochem. Behav. 79: 691-9

Diamond A, Zola-Morgan S, Squire LR (1989) Successful performance by monkeys with lesions of the hippocampal formation on $\mathrm{AB}$ and object retrieval, two tasks that mark developmental changes in human infants. Behav. Neurosci. 103: 526-37 
Egawa T, Mishima K, Matsumoto Y, Iwasaki K, Fujiwara M (1997) Rolipram and its optical isomers, phosphodiesterase 4 inhibitors, attenuated the scopolamine-induced impairments of learning and memory in rats. Jpn. J. Pharmacol. 75: 275-281

Ferrari F, Ottani A, Giuliani D (2002) Influence of sildenafil on central dopamine-mediated behaviour in male rats. 70: 1501-8

Frey U, Huang YY, Kandel ER (1993) Effects of cAMP simulate a late stage of LTP in hippocampal CA1 neurons. Science 260: 1661-4

Friedrich A, Thomas U, Muller U (2004) Learning at different satiation levels reveals parallel functions for the cAMP-protein kinase A cascade in formation of long-term memory. J. Neurosci. 24: 4460-8

Garthwaite J, Boulton CL (1995) Nitric oxide signaling in the central nervous system. Annu. Rev. Physiol. 57: 683-706

Imanishi T, Sawa A, Ichimaru Y, Miyashiro M, Kato S, Yamamoto T, Ueki S (1997) Ameliorating effects of rolipram on experimentally induced impairments of learning and memory in rodents. Eur. J. Pharmacol. 321: 273-278

Jentsch JD, Roth RH, Taylor JR (2000) Object retrieval/detour deficits in monkeys produced by prior subchronic phencyclidine administration: evidence for cognitive impulsivity. Biol. Psychiatry. 48: 415-24

Jentsch JD, Taylor JR, Elsworth JD, Redmond DE, Jr., Roth RH (1999a) Altered frontal cortical dopaminergic transmission in monkeys after subchronic phencyclidine exposure: involvement in frontostriatal cognitive deficits. Neuroscience 90: 823-32

Jentsch JD, Taylor JR, Redmond DE, Jr., Elsworth JD, Youngren KD, Roth RH (1999b) Dopamine D4 receptor antagonist reversal of subchronic phencyclidine-induced object retrieval/detour deficits in monkeys. Psychopharmacology (Berl) 142: 78-84

Lipina SJ, Colombo JA (2001) Dissociated functional recovery in parkinsonian monkeys following transplantation of astroglial cells. Brain. Res. 911: 176-80

Lu YF, Hawkins RD (2002) Ryanodine receptors contribute to cGMP-induced late-phase LTP and CREB phosphorylation in the hippocampus. J. Neurophysiol. 88: 1270-8

Matsumoto Y, Unoki S, Aonuma H, Mizunami M (2006) Critical role of nitric oxide-cGMP cascade in the formation of cAMP-dependent long-term memory. Learn. Mem. 13: 35-44

Maxwell CR, Kanes SJ, Abel T, Siegel SJ (2004) Phosphodiesterase inhibitors: a novel mechanism for receptor-independent antipsychotic medications. Neuroscience 129: 101-107

Patil CS, Singh VP, Kulkarni SK (2006) Modulatory effect of sildenafil in diabetes and electroconvulsive shock-induced cognitive dysfunction in rats. Pharmacol. Rep. 58: 373-380

Prickaerts J, Sik A, van der Staay FJ, de Vente J, Blokland A (2005) Dissociable effects of acetylcholinesterase inhibitors and phosphodiesterase type 5 inhibitors on object recognition memory: acquisition versus consolidation. Psychopharmacology (Berl) 177: 381-390

Prickaerts J, Sik A, van Staveren WC, Koopmans G, Steinbusch HW, van der Staay FJ, de Vente J, Blokland A (2004) Phosphodiesterase type 5 inhibition improves early memory consolidation of object information. Neurochem. Int. 45: 915-928

Prickaerts J, Steinbusch HW, Smits JF, de Vente J (1997) Possible role of nitric oxide-cyclic GMP pathway in object recognition memory: effects of 7-nitroindazole and zaprinast. Eur. J. Pharmacol. 337: 125-136

Prickaerts J, van Staveren WC, Sik A, Markerink-van Ittersum M, Niewohner U, van der Staay FJ, Blokland A, de Vente J (2002) Effects of two selective phosphodiesterase type 5 inhibitors, sildenafil and vardenafil, on object recognition memory and hippocampal cyclic GMP levels in the rat. Neuroscience 113: 351-361

Ramos BP, Birnbaum SG, Lindenmayer I, Newton SS, Duman RS, Arnsten AF (2003) Dysregulation of protein kinase a signaling in the aged prefrontal cortex: new strategy for treating age-related cognitive decline. Neuron 40: 835-45

Rodefer JS, Murphy ER, Baxter MG (2005) PDE10A inhibition reverses subchronic PCP-induced deficits in attentional set-shifting in rats. Eur. J. Neurosci. 21: 1070-1076

Roitberg BZ, Emborg ME, Sramek JG, Palfi S, Kordower JH (2002) Behavioral and morphological comparison of two nonhuman primate models of Huntington's disease. Neurosurgery 50: 137-45; discussion 145-6

Rose GM, Hopper A, De Vivo M, Tehim A (2005) Phosphodiesterase inhibitors for cognitive enhancement. Curr. Pharm. Des. 11: 3329-34 
Rutten K, Lieben C, Smits L, Blokland A (2007a) The PDE4 inhibitor rolipram reverses object memory impairment induced by acute tryptophan depletion in the rat.

Rutten K, Prickaerts J, Blokland A (2006) Rolipram reverses scopolamine-induced and time-dependent memory deficits in object recognition by different mechanisms of action. Neurobiol. Learn. Mem. 85: 132-8

Rutten K, Prickaerts J, Hendrix M, van der Staay FJ, Sik A, Blokland A (2007b) Time-dependent involvement of cAMP and cGMP in consolidation of object memory: Studies using selective phosphodiesterase type 2, 4 and 5 inhibitors. Eur. J. Pharmacol. 558: 107-112

Rutten K, VenteJD, SikA, Ittersum MM, PrickaertsJ, BloklandA(2005)TheselectivePDE5inhibitor, sildenafil,improves objectmemoryin Swiss miceand increases cGMPlevels in hippocampal slices. Behav. Brain. Res.164:11-6

Schneider JS, Roeltgen DP (1993) Delayed matching-to-sample, object retrieval, and discrimination reversal deficits in chronic low dose MPTP-treated monkeys. Brain. Res. 615: 351-4

Schoffelmeer AN, Wardeh G, Mulder AH (1985) Cyclic AMP facilitates the electrically evoked release of radiolabelled noradrenaline, dopamine and 5-hydroxytryptamine from rat brain slices. Naunyn Schmiedebergs Arch. Pharmacol. 330: 74-6

Shafiei M, Mahmoudian M, Rostami P, Nemati F (2006) Effect of sildenafil (Viagra) on memory retention of a passive avoidance response in rats. Acta Physiol. Hung. 93: 53-59

Singh N, Parle M (2003) Sildenafil improves acquisition and retention of memory in mice. Indian J. Physiol. Pharmacol. 47: 318-324

Son H, Lu YF, Zhuo M, Arancio O, Kandel ER, Hawkins RD (1998) The specific role of cGMP in hippocampal LTP. Learn. Mem. 5: 231-45

Taylor JR, Elsworth JD, Roth RH, Sladek JR, Jr., Redmond DE, Jr. (1990a) Cognitive and motor deficits in the acquisition of an object retrieval/detour task in MPTP-treated monkeys. Brain 113 ( Pt 3): 617-37

Taylor JR, Roth RH, Sladek JR, Jr., Redmond DE, Jr. (1990b) Cognitive and motor deficits in the performance of an object retrieval task with a barrier-detour in monkeys (Cercopithecus aethiops sabaeus) treated with MPTP: long-term performance and effect of transparency of the barrier. Behav. Neurosci. 104: 564-76

van Staveren WC, Steinbusch HW, Markerink-van Ittersum M, Behrends S, de Vente J (2004) Species differences in the localization of cGMP-producing and NO-responsive elements in the mouse and rat hippocampus using cGMP immunocytochemistry. Eur. J. Neurosci. 19: 2155-2168

Walker SC, Mikheenko YP, Argyle LD, Robbins TW, Roberts AC (2006) Selective prefrontal serotonin depletion impairs acquisition of a detour-reaching task. Eur. J. Neurosci. 23: 3119-3123

Weishaar RE, Cain MH, Bristol JA (1985) A new generation of phosphodiesterase inhibitors: multiple molecular forms of phosphodiesterase and the potential for drug selectivity. J. Med. Chem. 28: 537-45

Zhang HT, Huang Y, Suvarna NU, Deng C, Crissman AM, Hopper AT, De Vivo M, Rose GM, O'Donnell J M (2005) Effects of the novel PDE4 inhibitors MEM1018 and MEM1091 on memory in the radial-arm maze and inhibitory avoidance tests in rats. Psychopharmacology (Berl)

Zhang HT, O'Donnell JM (2000) Effects of rolipram on scopolamine-induced impairment of working and reference memory in the radial-arm maze tests in rats. Psychopharmacology (Berl) 150: 311-316

Zhuo M, Hu Y, Schultz C, Kandel ER, Hawkins RD (1994) Role of guanylyl cyclase and cGMP-dependent protein kinase in long-term potentiation. Nature 368: 635-9

Zufall F (1996) Cyclic nucleotide-gated channels, nitric oxide, and neural function. Neuroscientist 2: 24-32 


\section{General Discussion}




\section{GENERAL DISCUSSION AND CONCLUSION}

Although the underlying mechanisms of learning and memory are not yet explained or fully understood, experimental results from morphology, electrophysiology, biochemistry, and behavioral experiments point towards critical roles for cAMP and cGMP in this process. These second messengers play an important role in intracellular signaling (Bailey et al. 1996; Son et al. 1998) and in processes of neuroplasticity such as long term potentiation (LTP). Hippocampal LTP has been proposed to be a neurophysiological correlate of memory (Bliss and Collingridge 1993). The studies presented in this thesis investigated the effects of different PDE inhibitors on memory performance in several test models (object recognition, fear conditioning and object retrieval) and species (mice, rats and cynomolgus macaques). The results from these studies support the importance of the role of the second messengers cAMP and cGMP in learning and memory processes.

As described previously, two important studies showed specific and time dependent roles of cAMP and cGMP in memory (Bernabeu et al. 1996; Prickaerts et al. 2002a). Intra-hippocampal injections of a cAMP analogue (8Br-cAMP) enhanced memory performance only when injected $3 \mathrm{~h}$ after learning, whereas injections of a cGMP analogue (8Br-cGMP) was only effective when administered directly after the learning trial. These findings advocate specific roles for cGMP and cAMP in memory processes and imply differential cellular underlying pathways.

A large part of this thesis investigated the effects of specific PDE-Is on long-term memory performance and the time dependent differences between cAMP- and cGMP selective PDEs in the object recognition task (ORT) (chapters 2-4). Furthermore, the effects of PDEs on short-term memory were investigated in deficit models (chapters 3 and 5). Next, the effects of specific isoform knock-out of the PDE4 enzyme (i.e. PDE4B or PDE4D) on fear conditioning memory were investigated in a knock-out mouse model (Chapter 6). Finally, the effects of PDE4 and PDE5 inhibition were investigated in a non-human primate model of cognition, the object retrieval task (chapter 7).

\section{Effects of PDE inhibition on unimpaired long-term memory}

\section{PDE5 Inhibition}

Previous studies showed memory enhancing effects of PDE5-I on long-term memory in rats directly after the learning trial in the ORT (Prickaerts et al. 2004). We investigated the effects of sildenafil directly after the first trial in the C57/B16 mouse. The effects of PDE5-I were never before investigated in the mouse object recognition paradigm. Sildenafil $(1 \mathrm{mg} / \mathrm{kg})$ improved ORT performance in these mice and also enhanced cGMP immunoreactivity (cGMP-IR) in varicosities of the CA3 region of the hippocampus (See Chapter 2 or Rutten et al. 2005). Evidence has been presented that behavioral improvement of memory 
performance after sildenafil treatment might in part be mediated by an effect on E-LTP (Ingram et al. 1996). The pre-synaptic action of $\mathrm{NO} / \mathrm{sGC/cGMP}$ is assumed to be part of the mechanism of E-LTP. Since our behavioral results were observed $24 \mathrm{~h}$ after learning, they outlast the period of E-LTP (i.e. maximally $3 \mathrm{~h}$ ), but it is possible that E-LTP is converted into L-LTP, as has been observed recently (Pang et al. 2004). Of note, the latter has been associated with a post-synaptic localization. Considering the absence of colocalization of cGMP-immunoreactivity with synaptophysin in our immunucytochemical study, it could be concluded that sildenafil also acts post-synaptically. Nevertheless, it might also be the case that the used detection methods are not sensitive enough to pick up a pre-synaptic signal. Recently, it was demonstrated that NO and cGMP act both pre- and post-synaptically during induction of a form of E-LTP (Wang et al. 2005). In addition, Lu and Hawkins (2002) showed that post-synaptically localized cGMP contributes to L-LTP. To resolve this issue, studies are needed in which the PDE5 enzyme is localized at a sub-cellular level using a selective PDE5 antibody. At present a selective PDE5 antibody has been generated in our laboratory and we are awaiting the first immunohistochemical results.

To further investigate the role of the treatment time of different PDEs on object memory, we administered the PDE5-I vardenafil directly after, $1 \mathrm{~h}, 3 \mathrm{~h}$ or $6 \mathrm{~h}$ after learning in rats (See chapter 4 or Rutten et al. 2006b). We observed that only when administered directly after learning the PDE5-I was effective in ORT performance corroborating the previous finding of a role of PDE5-I in early consolidation processes (Prickaerts et al. 2004). Since in the same study the PDE4-I rolipram was not active directly after learning, but only $3 \mathrm{~h}$ after learning we suggest different working mechanisms for cAMP or cGMP dependent PDE-Is. This will be discussed in more detail below.

\section{PDE4 inhibition}

Based on the finding that intra-hippocampal injections of cAMP only enhanced memory when injected $3 \mathrm{~h}$ after training we assumed that rolipram would only affect late consolidation processes. In a first study we tested the effects of rolipram in the ORT when administered before learning (i.e. acquisition), immediately after learning (early consolidation) and $3 \mathrm{~h}$ after learning (late consolidation). As expected we found that rolipram was effective only when injected 3 h after the learning trial (see Chapter 3 and Rutten et al. 2006a). Thus, rolipram had no effect on acquisition or early consolidation, but enhanced late consolidation processes.

This finding was repeated in a second study that further examined the time-dependent effects of PDE-Is on object recognition memory. Rolipram was administered directly, $1 \mathrm{~h}$, $3 \mathrm{~h}$ or $6 \mathrm{~h}$ after the learning trial and was only effective $3 \mathrm{~h}$ after learning (see Chapter 4 and Rutten et al. 2006b). These findings again suggest a role for rolipram in late consolidation processes. The underlying mechanisms of PDE4-I and memory enhancement are not yet fully understood. However, evidence suggests that elevation of cAMP activates the cAMP/ PKA/CREB pathway that is involved in the process of L-LTP. This process leads to gene tran- 
scription and physical long lasting changes at the level of the synapse. The activity of rolipram reported across a range of different models and experimental conditions in rodents is remarkable and suggests that PDE4-Is possess robust cognitive-enhancing properties.

\section{PDE2 inhibition}

The PDE2 enzyme hydrolyses both cAMP and cGMP. To our knowledge, BAY 60-7550 is the only selective PDE2-I that has been tested in learning and memory models (Boess et al. 2004; Rutten et al. 2006b). In this thesis, the effects of BAY 60-7550 (3 mg/kg, p.o.) on object recognition memory were investigated and the effect of time of treatment was studied (Chapter 3 and Rutten et al. 2006b). We found an effect of BAY 60-7550 on object memory when it was given directly after training. This might be related to elevated cGMP levels, as the effect was observed at a drug administration time point where vardenafil affected recognition memory in the same study. In addition, improved object memory was observed when the PDE2-I was injected 3 h after training. Similar to the results of the rolipram study, these effects might be mediated by the elevation of CAMP levels and the process of late consolidation.

The results from the experiment with this PDE2-I support the notion of a specific and time-critical role of cGMP and cAMP in memory consolidation and are consistent with the results obtained after treatment with rolipram or vardenafil. Based on this study and previous studies with PDE4 and PDE5 inhibitors we suggest a role for cGMP in early consolidation processes and cAMP for late consolidation processes of memory.

\section{Effects of PDE inhibition in deficit models of short-term memory}

In the literature, short-term memory effects of PDE4-Is are predominantly measured in pharmacological deficit models (see Table 3 of introduction). To also evaluate the effects of rolipram in memory deficit models two more experiments were performed, which were described in the present thesis. The first study showed ameliorating effects of rolipram (0.1 mg/ $\mathrm{kg}$ ) in the scopolamine deficit model when both were administered 30 min before learning (see Chapter 3 and Rutten et al. 2006a). This is in concordance with the literature that has repeatedly shown that rolipram reverses the deficit caused by scopolamine. The second study tested the effects on memory performance of rolipram in combination with an acute dose of a tryptophan free mixture. Acute tryptophan depletion (ATD) has shown to impair memory performance in both humans and rodents (Lieben et al. 2005a; Lieben et al. 2004c; Park et al. 1994; Riedel et al. 1999; Sambeth et al. in press; Schmitt et al. 2000). We found that rolipram reversed the memory deficit caused by ATD. In this experiment the tryptophan depleted mixture was administered 3 h before learning and rolipram 30 min before learning (See Chapter 5 and Rutten et al. in press). The effective dose of rolipram was similar $(0.1 \mathrm{mg} / \mathrm{kg})$ as in the scopolamine study. Thus, PDE4-I can ameliorate both a serotonergic and a cholinergic deficit in object recognition performance. However, the precise underlying mechanisms of action are still unknown. Since in these deficit models of the ORT shortterm memory is examined, no gene transcription or protein synthesis is required. Thus, the 
cAMP/PKA/CREB pathway may not be involved. Possibly, rolipram ameliorates the effects of scopolamine through enhancement of cholinergic, noradrenergic and/or dopaminergic turnover (Imanishi et al. 1997; Schoffelmeer et al. 1985). The same could be true for amelioration of the serotonergic system. PDE4 is involved in beta-adrenergic receptor mediated cAMP signaling, which has been shown to mediate some effects of antidepressants (Ye and O’Donnell 1996).

Thus, PDE4 inhibitors can improve short-term memory by enhancement of cAMP levels, likely via modulation of neurotransmitter activity, whereas improvements in acquisition and consolidation processes of long-term memory are likely mediated by increased cAMP levels, which activate the cAMP/PKA/CREB pathway.

\section{Role of PDE4 isoforms: a genetic model}

Whereas PDE4 inhibitors are enticing targets for the treatment of cognitive impairing disease such as Alzheimer's, it has been very difficult to circumvent the adverse effects that often accompany the beneficial effects of the PDE4-Is. Thus, one approach to minimize the adverse effects would be to develop selective PDE4 isoform inhibitors depending on the characterization and understanding of which isoform (s) was involved in learning/memory. The objective of this experiment was to determine whether either or both of the brain enriched isoforms, B or D, were involved in mediating associative memory as assessed by the delayed fear conditioning and morris water maze test using selective PDE4 gene knock-out mice.

Unpublished results showed that LTP was enhanced in PDE4-D knock-out mice and LTD was enhanced in PDE4-B knock-out mice. We expected PDE4 KO to perform better than WT animals, since these animals are believed to have higher cAMP levels. However, this was not the case; PDE4-D knock-out mice even showed memory impairment in the fear conditioning task, whereas PDE4-B knock-out mice showed no differences in performance as compared to wild type littermates. How to explain the observed behavioral impairment for the PDE4-D KOs remains speculative. A possible explanation could be that developmental changes occur in these mice that cause the deficit. These knock-out mice show lower birth weights and are encountered with harmful differences in maternal behavior as compared with wild-type littermates. Another explanation could be that adaptive changes to the missing enzyme have occurred in the brain and as a result baseline enzyme and neurotransmitter levels are altered. Furthermore, knock-out of the PDE4-D gene may cause an up-regulation of other PDEs that result in impaired fear conditioning performance. Due to these developmental differences of PDE4-D knock-out mice no clear conclusions can be drawn at this point. Nevertheless, specific PDE4 isoform research is necessary since rolipram is currently an invalidated clinical target because of side effects. Severe side effects, such as emesis, have always been a dose limiting factor for clinical use of rolipram as an antidepressant or cognitive enhancer (Dyke and Montana 2002; Hebenstreit et al. 1989; Norman et al. 1992a; Overstreet et al. 1989). The PDE4-D isoform has been implied to produce emesis (Robichaud et al. 2002), which is one of the most prominent negative side effects of treatment with PDE4 inhibitors. Thus, targeting specific PDE4 iso- 
forms could reduce the dose-limiting side effects of the presently available PDE4-I. SiRNA is a recently developed technique which is used to silence genes (Xia et al. 2002) and could therefore be an interesting alternative for $\mathrm{KO}$ animals.

Indirect evidence suggests that PDE4-A and PDE4-B are involved in signaling pathways involved in affective behavior (Ye et al. 2000) and memory processes (Ahmed and Frey 2003), respectively. Recently, the antidepressant potential of PDE4-A in the hippocampus has been found to be related to specific splice variants of this PDE4 isoform (D'Sa et al. 2005). The same probably holds for PDE4-B and memory (Ahmed and Frey 2005). To our knowledge, there are no selective PDE4 inhibitors available for the three PDE4 isoforms yet. Thus, the role of the different PDE4 isoforms in the hippocampus with respect to affective and cognitive behavior could be evaluated directly using a novel technique such as SiRNA. Finally, using SiRNA techniques, there are no developmental aspects involved as is the case in the PDE4 KO mice.

\section{Effects of PDE inhibition in higher species}

\section{Non-human primates}

Notwithstanding these intriguing findings in rodents, PDE4 is clinically not validated as a target for the treatment of cognitive disorders and the rationale would be strengthened if more data in higher species such as non-human primates became available (Blokland et al. 2006 , in press). In a first study, a trend was found for rolipram to improve delayed responding performance in young unimpaired rhesus monkeys, although performance in aged, impaired monkeys was decreased (Ramos et al. 2003). The primate task involved activity of the prefrontal cortex and it is possible that PDE4 inhibitors possess differential effects in hippocampal/amygdala-mediated tasks and frontal cortex-mediated tasks. Further, Ramos et al (2003) observed a disinhibited cAMP/PKA pathway in the prefrontal cortex of aged animals, suggesting that prefrontal cortex cAMP levels should be inhibited instead of elevated to improve cognitive functions. In this thesis, we investigated the cognition enhancing properties of rolipram in the object retrieval task in non-human primates.

To our knowledge, PDE5-I have never before been evaluated in primate models of cognition. This thesis presented the first study in which the cognitive effects of PDE5-Is were investigated in a non-human primate model. The object retrieval task requires prefrontal functioning and is likely to capture attention and response inhibition (Diamond et al. 1989). Rolipram and sildenafil were administered to cynomolgus macaques $1 \mathrm{~h}$ prior to the OR task. In our experiment we found that both rolipram and sildenafil effectively improved prefrontal performance in adult monkeys (see Chapter 7). Although the underlying pathways are not yet fully understood, these results further strengthen the possibility of PDE4-I and PDE5-I as a clinical targets for cognitive improvement. 


\section{Humans}

To our knowledge, the effects of PDE-I have not been investigated in humans yet. However unpublished data suggest some effects of PDE5-I on human memory. In this double blind placebo controlled study, two groups of people were treated with the PDE5-I sildenafil and their memory performance was evaluated. The first group consisted of students from the department of psychology of the Maastricht University; the second group consisted of subjects older than 60 years. Preliminary results suggested no general effect on memory of the PDE-I. However, post-hoc analysis showed that when subjects were divided into good and bad performers based on the memory performance in the vehicle condition, the group of bad performers benefited from the sildenafil treatment in both age groups. Thus, when people with poor memory were treated with sildenafil their memory performance increased significantly. These results are preliminary and further investigation will be required. An ongoing study will screen subjects on memory performance first and then administration of sildenafil will be investigated.

PDE4-Is have not been tested in humans yet, possibly because the most used PDE4-I rolipram produces severe emetic side effects.

\section{Central vascular effects of PDEs}

PDE-Is, in particular PDE5-Is, are known to have peripheral effects on vasodilatation. It has not yet been fully determined whether PDE-Is may also have central effects on blood flow and glucose metabolism. A possible alternative explanation to all experiments described above could be that PDE-Is enhance central blood flow and glucose metabolism and thereby enhance cellular functioning in, for example, the hippocampus, and thus memory performance. However, studies by Prickaerts et al (1997) showed that the PDE5 inhibitor zaprinast clearly improved object memory in rats at $10 \mathrm{mg} / \mathrm{kg}$ (i.p.) but did not affect mean arterial blood pressure at this dosage (Prickaerts et al. 1997). Similar results on object memory and blood pressure have been observed for sildenafil administration in rats (Prickaerts et al. 2004). Taking this into account, it is unlikely that the memory enhancing effects of PDE5 inhibitors can simply be explained through changes in blood flow or blood pressure (for a more detailed review see: (Prickaerts et al. 2004). In an ongoing study by our group and the University of Edinburgh in Scotland, the effects rolipram $(0.03 \mathrm{mg} / \mathrm{kg})$ and vardenafil $(1 \mathrm{mg} / \mathrm{kg})$ are studied on central blood flow and glucose metabolism. The results from this study were not yet available at the time of submitting the present thesis. Nevertheless, on the basis of the available data we do not expect that the memory enhancing effects of PDEs can be explained by a simple increase in glucose metabolism. We hope that the data on cerebral blood flow and glucose metabolism can confirm our notion. 


\section{Final evaluation of PDEs in cognition}

Taken together, the results presented in the present thesis show convincing cognitive enhancing properties of PDE-Is. The enhancing effects of PDE-I on memory performance have been shown in rats, mice and primates. Evidence suggests differential time dependent effects of cGMP or cAMP selective PDEs. It appears that cGMP is mainly involved in early consolidation processes and CAMP in late consolidation processes. The underlying pathways are yet to be fully explained, although cellular processes that are related to LTP seem to be a possible mechanism. The cGMP/PKG/CREB pathway for early consolidation processes and the $\mathrm{CAMP} / \mathrm{PKA} / \mathrm{CREB}$ pathway for late consolidation processes might be the most probable mechanisms underlying the observed behavioral effects. In addition, the pre-synaptic NO/ sGC/GMP pathway may also exert effects on short-term memory, but this has not yet been investigated at present. Furthermore, cAMP may also be involved in short-term memory processes through enhanced neurotransmitter release. Finally, the understanding of the underlying mechanisms of PDE-Is and cognition can be further complicated, since evidence has shown that E-LTP can be converted to L-LTP.

Isoform specific studies are promising new ways to further investigate the underlying mechanisms of cognition enhancement in animal models. Genetic knock-out models for PDE4 show behavioral differences in cognition and depression, but developmental deficits in these animals might confound the outcome of these studies. Novel techniques, such as gene silencing, could further increase our understanding of the mechanisms of PDE-Is in cognition and might provide more selective targets for cognitive enhancement.

\section{References}

Ahmed T, Frey JU (2003) Expression of the specific type IV phosphodiesterase gene PDE4B3 during different phases of long-term potentiation in single hippocampal slices of rats in vitro. Neuroscience 117: 627-638

Ahmed T, Frey JU (2005) Phosphodiesterase 4B (PDE4B) and cAMP-level regulation within different tissue fractions of rat hippocampal slices during long-term potentiation in vitro. Brain. Res. 1041: 212-222

Bailey CH, Bartsch D, Kandel ER (1996) Toward a molecular definition of long-term memory storage. Proc. Natl. Acad. Sci. USA 93: 13445-52

Bernabeu R, Schmitz P, Faillace MP, Izquierdo I, Medina JH (1996) Hippocampal cGMP and cAMP are differentially involved in memory processing of inhibitory avoidance learning. Neuroreport 7: 585-588

Bliss TV, Collingridge GL (1993) A synaptic model of memory: long-term potentiation in the hippocampus. Nature 361: 31-9

Blokland A, Schreiber R, Prickaerts J (2006, in press) Improving Memory: A role for Phosphodiesterases. Curr. Pharm. Des.

Boess FG, Hendrix M, van der Staay FJ, Erb C, Schreiber R, van Staveren W, de Vente J, Prickaerts J, Blokland A, Koenig G (2004) Inhibition of phosphodiesterase 2 increases neuronal cGMP, synaptic plasticity and memory performance. Neuropharmacology 47: 1081-92

D'Sa C, Eisch AJ, Bolger GB, Duman RS (2005) Differential expression and regulation of the cAMP-selective phosphodiesterase type $4 \mathrm{~A}$ splice variants in rat brain by chronic antidepressant administration. Eur. J. Neurosci. 22: $1463-1475$ 
Diamond A, Zola-Morgan S, Squire LR (1989) Successful performance by monkeys with lesions of the hippocampal formation on $\mathrm{AB}$ and object retrieval, two tasks that mark developmental changes in human infants. Behav. Neurosci. 103: 526-37

Dyke HJ, Montana JG (2002) Update on the therapeutic potential of PDE4 inhibitors. Expert Opin. Investig. Drugs. 11: 1-13

Hebenstreit GF, Fellerer K, Fichte K, Fischer G, Geyer N, Meya U, Sastre-y-Hernandez M, Schony W, Schratzer M, Soukop W, et al. (1989) Rolipram in major depressive disorder: results of a double-blind comparative study with imipramine. Pharmacopsychiatry 22: 156-160

Imanishi T, Sawa A, Ichimaru Y, Miyashiro M, Kato S, Yamamoto T, Ueki S (1997) Ameliorating effects of rolipram on experimentally induced impairments of learning and memory in rodents. Eur. J. Pharmacol. 321: 273-278

Ingram DK, Shimada A, Spangler EL, Ikari H, Hengemihle J, Kuo H, Greig N (1996) Cognitive enhancement. New strategies for stimulating cholinergic, glutamatergic, and nitric oxide systems. Ann. N. Y. Acad. Sci. 786:348-61

Lieben CK, Blokland A, Sik A, Sung E, van Nieuwenhuizen P, Schreiber R (2005) The selective 5-HT6 receptor antagonist Ro4368554 restores memory performance in cholinergic and serotonergic models of memory deficiency in the rat. Neuropsychopharmacology 30: 2169-2179

Lieben CK, van Oorsouw K, Deutz NE, Blokland A (2004) Acute tryptophan depletion induced by a gelatin-based mixture impairs object memory but not affective behavior and spatial learning in the rat. Behav. Brain. Res. 151: 53-64

Norman TR, Judd FK, Burrows GD (1992) New pharmacological approaches to the management of depression: from theory to clinical practice. Aust. N. Z. J. Psychiatry 26: 73-81

Overstreet DH, Double K, Schiller GD (1989) Antidepressant effects of rolipram in a genetic animal model of depression: cholinergic supersensitivity and weight gain. Pharmacol. Biochem. Behav. 34: 691-696

Pang PT, Teng HK, Zaitsev E, Woo NT, Sakata K, Zhen S, Teng KK, Yung WH, Hempstead BL, Lu B (2004) Cleavage of proBDNF by tPA/plasmin is essential for long-term hippocampal plasticity. Science 306: 487-91

Park SB, Coull JT, McShane RH, Young AH, Sahakian BJ, Robbins TW, Cowen PJ (1994) Tryptophan depletion in normal volunteers produces selective impairments in learning and memory. Neuropharmacology 33: 575-588

Prickaerts J, de Vente J, Honig W, Steinbusch HW, Blokland A (2002) cGMP, but not cAMP, in rat hippocampus is involved in early stages of object memory consolidation. Eur. J. Pharmacol. 436: 83-87

Prickaerts J, Sik A, van Staveren WC, Koopmans G, Steinbusch HW, van der Staay FJ, de Vente J, Blokland A (2004) Phosphodiesterase type 5 inhibition improves early memory consolidation of object information. Neurochem. Int. 45: 915-928

Prickaerts J, Steinbusch HW, Smits JF, de Vente J (1997) Possible role of nitric oxide-cyclic GMP pathway in object recognition memory: effects of 7-nitroindazole and zaprinast. Eur. J. Pharmacol. 337: 125-136

Ramos BP, Birnbaum SG, Lindenmayer I, Newton SS, Duman RS, Arnsten AF (2003) Dysregulation of protein kinase a signaling in the aged prefrontal cortex: new strategy for treating age-related cognitive decline. Neuron 40: 835-45

Riedel WJ, Klaassen T, Deutz NE, van Someren A, van Praag HM (1999) Tryptophan depletion in normal volunteers produces selective impairment in memory consolidation. Psychopharmacology (Berl) 141: 362-369

Robichaud A, Savoie C, Stamatiou PB, Lachance N, Jolicoeur P, Rasori R, Chan CC (2002) Assessing the emetic potential of PDE4 inhibitors in rats. Br. J. Pharmacol. 135: 113-118

Rutten K, Lieben C, Smits L, Blokland A (in press) The PDE4 inhibitor rolipram reverses the object memory impairment induced by acute tryptophan depletion. Neuropharmacology

Rutten K, Prickaerts J, Blokland A (2006a) Rolipram reverses scopolamine-induced and time-dependent memory deficits in object recognition by different mechanisms of action. Neurobiol. Learn. Mem. 85: 132-8

Rutten K, Prickaerts J, Hendrix M, van der Staay FJ, Sik A, Blokland A (2006b) Time-dependent involvement of cAMP and cGMP in consolidation of object memory: Studies using selective phosphodiesterase type 2, 4 and 5 inhibitors. Eur. J. Pharmacol.

Rutten K, Vente JD, Sik A, Ittersum MM, Prickaerts J, Blokland A (2005) The selective PDE5 inhibitor, sildenafil, improves object memory in Swiss mice and increases cGMP levels in hippocampal slices. Behav. Brain. Res. 164: 11-6 
Sambeth A, Blokland A, Harmer C, Klilkens T, Nathan P, Porter R, Schmitt J, Scholtissen B, Sobczak S, Young A, Riedel W (in press) Sex differences in the effect of acute tryptophan depletion on declarative episodic memory: A pooled analysis of nine studies. Neurosci. Biobehav. Rev.

Schmitt JA, Jorissen BL, Sobczak S, van Boxtel MP, Hogervorst E, Deutz NE, Riedel WJ (2000) Tryptophan depletion impairs memory consolidation but improves focussed attention in healthy young volunteers. J. Psychopharmacol. 14: 21-29

Schoffelmeer AN, Wardeh G, Mulder AH (1985) Cyclic AMP facilitates the electrically evoked release of radiolabelled noradrenaline, dopamine and 5-hydroxytryptamine from rat brain slices. Naunyn Schmiedebergs Arch. Pharmacol. 330: 74-6

Son H, Lu YF, Zhuo M, Arancio O, Kandel ER, Hawkins RD (1998) The specific role of cGMP in hippocampal LTP. Learn. Mem. 5: 231-45

Wang HG, Lu FM, Jin I, Udo H, Kandel ER, de Vente J, Walter U, Lohmann SM, Hawkins RD, Antonova I (2005) Presynaptic and postsynaptic roles of NO, cGK, and RhoA in long-lasting potentiation and aggregation of synaptic proteins. Neuron 45: 389-403

Xia H, Mao Q, Paulson HL, Davidson BL (2002) siRNA-mediated gene silencing in vitro and in vivo. Nat. Biotechnol. 20: 1006-1010

Ye Y, Jackson K, O’Donnell JM (2000) Effects of repeated antidepressant treatment of type 4A phosphodiesterase (PDE4A) in rat brain. J. Neurochem. 74: 1257-1262

Ye Y, O’Donnell JM (1996) Diminished noradrenergic stimulation reduces the activity of rolipram-sensitive, highaffinity cyclic AMP phosphodiesterase in rat cerebral cortex. J. Neurochem. 66: 1894-1902 
SUMMARY 


\section{SUMMARY}

This thesis describes studies investigating the effects of phosphodiesterase (PDE) inhibitors on learning and memory. During the last decennia, our understanding of the neurobiological processes underlying learning and memory has continuously improved, leading to the identification of targets for the development of memory-enhancing drugs. PDEs are enzymes that hydrolyze cyclic AMP (cAMP) and cyclic GMP (cGMP) in the body and the brain. Recently, evidence has been accumulating that these second messenger molecules cGMP and cAMP are very important in learning and memory processes. This thesis adds to the growing public interest into the effects of PDE- on cognition. The studies described in thesis show memory enhancing properties of different PDE-Is in different animal species and in different behavioral tests and models.

Chapter 1: An introduction is provided into the basics of the human memory system, animal models of learning and memory and possible underlying pathways that involve long term potentiation (LTP). Furthermore, an overview is given of the different PDEs that are known at present and we focus on three PDEs which have been identified as possible relevant targets for memory improvement: PDE2, PDE4 and PDE5. Finally, an extensive review of the literature on PDE-I and putative memory enhancement in behavioral models is presented.

Chapter 2: The effects of the in vivo application of the PDE5-I sildenafil on object recognition memory are described in relation to its administration in vitro using hippocampal slices in Swiss mice. To investigate a possible presynaptic underlying mechanism of action for PDE5-I we tried to co-localize cGMP immunoreactivity (cGMP-IR) with the pre-synaptic marker synaptophysin. Sildenafil improved memory performance in the ORT and cGMP-IR was increased in varicosities and some fibers in the CA1 area of the hippocampus. Furthermore, failed co-localization of cGMP with synaptophysin implies that either cGMP is not elevated at the presynaptic level (and thus does not work via a presynaptic mechanism of action), or that our mechanisms for measuring cGMP-IR are not sensitive enough to pick up small fluctuations in cGMP concentrations. Future studies with specific PDE5 antibodies will further elucidate these results.

Chapter 3: The effect of the selective PDE4-I rolipram on memory performance in rats was investigated using the object recognition task. Since, previous studies showed that intrahippocampal injections of 8Br-cAMP enhanced long-term memory only when administered $3 \mathrm{~h}$ after training, we wanted to investigate the time dependent administration of rolipram on long-term memory. Furthermore we investigated the effects of rolipram in a short-term memory deficit model, i.e. the scopolamine model in $1 \mathrm{~h}$ interval ORT. Using a $24 \mathrm{~h}$ interval in the ORT, rolipram showed an improvement in long-term memory performance only when injected $3 \mathrm{~h}$ after training, not when injected $30 \mathrm{~min}$ before or immediately after training. Furthermore, rolipram reversed the scopolamine-induced short-term memory deficit. Although the improved memory performance in both conditions is likely to be explained by elevated cAMP levels, two separate working mechanisms might explain these effects. 
Chapter 4: The time-dependent memory enhancing properties of three selective PDE-Is vardenafil (PDE5-I), rolipram (PDE4-I) and BAY 60-7550 (PDE2-I) were investigated in the ORT. In particular, the time-dependent involvement of cAMP and cGMP in memory consolidation was assessed by altering the time points of drug administration. Vardenafil, rolipram, and BAY 607550 were tested in rats with a $24 \mathrm{~h}$ delay interval in the ORT. The PDE-Is were administered at different time points, i.e. directly after, $1 \mathrm{~h}, 3 \mathrm{~h}$ and $6 \mathrm{~h}$ after T1. Vardenafil only showed an effect on object memory when injected directly after $\mathrm{T} 1$, rolipram only showed an improvement when injected $3 \mathrm{~h}$ after T1 and BAY 60-7550 improved memory when injected either directly after or $3 \mathrm{~h}$ after. No treatment effects were found at the $1 \mathrm{~h}$ or $6 \mathrm{~h}$ administration time points. These results suggest that different types of PDE-Is can affect different stages of memory consolidation. Moreover, time dependent administration of three different PDE-Is advocates specific roles of cAMP and cGMP in the long term memory consolidation processes.

Chapter 5: Previous studies showed that rolipram can reverse the cholinergic deficit caused by scopolamine. However underlying mechanisms of action remain obscure. This study investigated the effect of rolipram in a serotonergic memory deficit model of acute tryptophan depletion (ATD). First, the effects different treatment times of ATD on plasma tryptophan (TRP) values and ORT performance were investigated. ATD significantly lowered the plasma TRP ratio (TRP/ $L \mathrm{LNAA}$ ) to a maximum of $48 \%$, approximately $1 \mathrm{~h}$ after administration. Furthermore ATD impaired ORT performance when administered $3 \mathrm{~h}$ before testing. Rolipram $(0.1 \mathrm{mg} / \mathrm{kg})$ reversed the ATD induced serotonergic deficit. Possible mechanisms of action act through elevation of cAMP levels and downstream up-regulations of neurotransmitter systems.

Chapter 6: Currently, four isoforms of the PDE4 enzyme (A, B, C and D) have been identified, yet the requisite involvement of each of these isoforms in mediating LTM has yet to be elucidated. The intent of the present study was to use genetic knock-out (KO) mice to investigate the involvement of two of the PDE4 isoforms that have high brain expression, namely $\mathrm{D}$ and $\mathrm{B}$, in in vivo models of learning and memory. Adult, male PDE4-D and PDE4-B KO mice were first characterized in an associative learning paradigm using the fear conditioning model (FC) at two time points, $24 \mathrm{~h}$ for long term memory (LTM), and $1 \mathrm{~h}$ for short term memory (STM). Interestingly, whereas the PDE4 B KO mice demonstrated equivalent LTM and STM as compared to wild-type mice, the PDE4-D KO animals exhibited significant deficits in LTM as compared with their control littermates. Neither the PDE4-B or PDE4-D mice showed any alterations in Morris water maze (MWM) performance (acquisition or retention) as compared to wild-type controls. Whereas the deficit in LTM observed in the PDE4-D KO mice was not expected, and may be explained by adaptive responses occurring because of constitutive inactivity of this isoform throughout development, it does suggest that the PDE4-D isoform, possibly more so than PDE4-B may be of importance in learning and memory.

Chapter 7: Selective PDE-Is have been shown to improve long-term memory in several rodent models of cognition. However, studies evaluating the effects of PDE-I on cognition in unimpaired primates are very scarce. This study investigated the effect of the PDE4-I 
rolipram and the PDE5-I sildenafil on object retrieval (OR) performance. OR is a prefrontal cortical mediated task, which is likely to capture attention and response inhibition. Young adult male Cynomolgus macaques were trained in the OR task. Both rolipram and sildenafil significantly improved performance in the OR task. These findings complement and extend to the cognition-enhancing effects of cAMP and cGMP via PDE-I. However, the underlying mechanism of action and cellular pathways remain elusive.

Chapter 8: In the final chapter a general discussion of the findings in this thesis. Taken together, the results presented in the present thesis show convincing cognitive enhancing properties of PDE-Is. The enhancing effects of PDE-I on memory performance have been shown in rats, mice and primates. Evidence suggests differential time-dependent effects of cGMP or cAMP selective PDEs. It appears that cGMP is mainly involved in early consolidation processes and CAMP in late consolidation processes. The underlying pathways are yet to be fully explained, although cellular processes that are related to LTP seem to be a possible mechanism. The cGMP/PKG/CREB pathway for early consolidation processes and the CAMP/PKA/CREB pathway for late consolidation processes might be the most probable mechanisms underlying the observed behavioral effects. In addition, the pre-synaptic NO/ sGC/cGMP pathway may also exert effects on short-term memory, but this has not yet been investigated at present. Furthermore, cAMP may also be involved in short-term memory processes through enhanced neurotransmitter release. Finally, the understanding of the underlying mechanisms of PDE-Is and cognition can be further complicated, since evidence has shown that E-LTP can be converted to L-LTP. Future studies with specific antibodies for PDEs have to elucidate the pre or postsynaptic localization of PDEs and could further illuminate the underlying mechanisms of action. Recently our lab has developed a specific PDE5 antibody and the first immunohistochemical are expected in due course.

PDE-Is, in particular PDE5-Is, are known to have peripheral effects on vasodilatation. It has not yet been fully determined whether PDE-Is may also have central effects on blood flow and glucose metabolism. In this chapter we discussed why based on the literature it is not very likely that our memory enhancing effects of PDE-I are explained by central vascular effects.

Isoform specific studies are promising new ways to further investigate the underlying mechanisms of cognition enhancement in animal models. Genetic KO models for PDE4 show behavioral differences in cognition and depression, but developmental deficits in these animals might confound the outcome of these studies. Novel techniques, such as gene silencing, could further increase our understanding of the role of PDE (isoform) enzymes in cognition and might provide more selective targets for cognitive enhancement. 


\section{SAMENVATTING}




\section{SAMENVATTING}

De studies die beschreven worden in dit proefschrift tonen de effecten van phosphodiesterase (PDE) remmers op leren en het geheugen. De afgelopen jaren is onze kennis van de onderliggende processen van leren en het geheugen steeds beter geworden. Dit heeft geleid tot de identificatie van mogelijke targets voor de ontwikkeling van geheugenverbeterende medicijnen. PDEs zijn enzymen die in ons lichaam en in het brein cyclisch AMP (cAMP) en cyclisch GMP (cGMP) hydrolyseren. Steeds meer bewijs toont aan dat deze secundaire 'messenger' moleculen cAMP en cGMP een belangrijke rol spelen in geheugenprocessen. Dit proefschrift draagt bij aan de groeiende interesse in PDE remmers en cognitie. De in dit proefschrift beschreven experimenten tonen geheugen verbeterende effecten van PDE remmers in verschillende diersoorten en in verschillende gedragstaken en modellen.

Hoofdstuk 1: Er wordt een introductie gegeven van de basale opbouw van het menselijke geheugen systeem, dierexperimentele modellen voor leren en geheugen en de mogelijke onderliggende mechanismen, waaronder long term potentiatie (LTP). Verder wordt een overzicht gegeven van de op dit moment bekende PDEs en we gaan dieper in op drie PDEs die gekenmerkt zijn als mogelijke targets voor geheugenverbetering: PDE2, PDE4 en PDE5. Ten slotte wordt een uitgebreid overzicht van de literatuur over PDE remmers en mogelijke geheugenverbeterende effecten in diermodellen gegeven.

Hoofdstuk 2: De effecten van in vivo toediening van de PDE5 remmer sildenafil op het geheugen in de objectherkenningstaak (ORT) worden onderzocht in relatie tot de in vitro toediening op hippocampale coupes van Swiss muizen. Om een mogelijk presynaptisch onderliggend werkingsmechanisme van PDE5 remmers te onderzoeken werd geprobeerd om immunoreactiviteit van cGMP (cGMP-IR) te co-localiseren met de presynaptische marker synaptophysine. Sildenafil verbeterde het ORT geheugen in muizen en cGMP-IR werd waargenomen in varicositeiten en enkele vezels van het $C A 1$ gebied van de hippocampus. Er werd verder geen co-localisatie gevonden tussen cGMP-IR en synaptophysine. Dit kan betekenen dat cGMP niet verhoogd actief is in presynaptische gebieden (en het dus niet via een presynaptisch mechanisme werkt), of dat onze meettechnieken niet gevoelig genoeg zijn om kleine cGMP fluctuaties op te pikken.

Hoofdstuk 3: De effecten van de selectieve PDE4 remmer rolipram op het geheugen van ratten werden onderzocht in de ORT. Omdat eerdere studies lieten zien dat intra-hippocampale injecties van 8Br-cAMP het lange termijn geheugen alleen verbeterden wanneer de injecties 3 uur na training plaatsvonden, wilden we de effecten van tijd van toediening van rolipram op het lange termijn geheugen onderzoeken. Daarnaast werden de effecten van rolipram onderzocht in een model voor korte termijn geheugen, namelijk het scopolamine model met 1 uur interval in de ORT. Bij een 24 uur interval in de ORT verbeterde rolipram het lange termijn geheugen alleen wanneer het 3 uur na de training werd toegediend en niet 
wanneer het een half uur voor of direct na de training werd toegediend. Verder hief rolipram het korte termijn geheugen defect door scopolamine op. De gevonden geheugenverbeteringen van rolipram in beide condities worden waarschijnlijk veroorzaakt door verhoging van de cAMP concentraties, maar wij denken dat verschillende werkingsmechanismen deze effecten verklaren.

Hoofdstuk 4: De geheugenverbeterende effecten en de tijd van toediening van drie selectieve PDE remmers: vardenafil (PDE5 remmer), rolipram (PDE4 remmer) en BAY 60-7550 (PDE2 remmer) werden onderzocht in de ORT. De tijdsafhankelijke betrokkenheid van cAMP en cGMP bij de consolidatie van het geheugen werd onderzocht door de tijd van toediening te variëren. Vardenafil, rolipram en BAY 60-7550 werden in ratten getest met een 24 uur interval ORT. De PDE remmers werden op verschillende tijdspunten toegediend, namelijk: direct na, 1 uur, 3 uur of 6 uur na trial 1 (T1). Vardenafil verbeterde alleen het geheugen wanneer het direct na $\mathrm{T} 1$ werd toegediend, rolipram werkte alleen wanneer het 3 uur na T1 werd toegediend en BAY 60-7550 verbeterde het geheugen wanneer het of direct, of 3 uur na T1 werd toegediend. Geen effecten werden gevonden wanneer de drugs 1 uur of 6 uur na T1 werden toegediend. Deze resultaten suggereren dat verschillende PDE remmers verschillende fases van consolidatie processen beïnvloeden. Met andere woorden, de tijdsafhankelijke toediening van drie verschillende PDE remmers pleit voor specifieke betrokkenheid van cAMP en/of cGMP in consolidatie processen van het lange termijn geheugen.

Hoofdstuk 5: Eerder onderzoek toonde aan dat rolipram het cholinerge defect dat door scopolamine wordt veroorzaakt kan opheffen. Maar de onderliggende mechanismen zijn nog niet volledig bekend. In deze studie werden de effecten van rolipram onderzocht in een serotonerg defect model, namelijk dat van acute tryptofaan depletie (ATD). Allereerst werden de effecten van verschillende toedieningtijden van het ATD mengsel op de ORT prestatie en de tryptofaan (TRP) waarden in het bloedplasma bepaald. ATD zorgde voor een significante verlaging van de TRP ratio (TRP/ $L$ LNAA) in het bloed tot maximaal 48\%, ongeveer 1 uur na de toediening. Daarnaast verslechterde ATD de geheugenprestatie in de ORT wanneer het mengsel 3 uur voor de training werd toegediend. Rolipram was in staat het serotonerge geheugendefect op te heffen. Een mogelijke verklaring voor deze effecten is dat PDE4 remming via een verhoging van cAMP niveaus, de activiteit van diverse neurotransmitter systemen versterkt.

Hoofdstuk 6: Tot heden zijn er vier isovormen van het PDE4 enzym bekend (A, B, C en D) maar de respectievelijke betrokkenheid van elk van deze isovormen in de vorming van lange termijn geheugen moeten nog onderzocht worden. Het doel van deze studie was om de betrokkenheid te bestuderen van twee PDE4 isovormen die veel in het brein voorkomen, namelijk D en B, in in vivo modellen voor leren en geheugen. Hierbij werd gebruik gemaakt van genetische knock-out (KO) muizen. Volwassen mannelijke PDE4-D en PDE4-B KO muizen werden eerst gekarakteriseerd in een associatieve leertaak. Hierbij werd gebruik gemaakt 
van de fear conditioning (FC) test voor lange termijn geheugen (24 uur interval) en korte termijn geheugen (1 uur interval). De PDE4-B dieren toonden geen verschillen tussen KOs en wild-type muizen op korte en lange termijn geheugen. De PDE4-D KO muizen toonden echter wel een significante verslechtering in lange termijn geheugen in vergelijking met de controle wild-type muizen. Zowel de PDE4-D als de PDE4-B KO muizen lieten geen verschillen zien in de spatiële Morris water maze (MWM) test (acquisitie en retentie) ten opzichte van de wild-types. Hoewel de verslechtering bij de PDE4-D muizen onverwacht was en mogelijk verklaard kan worden door aanpassingsreacties die optreden door de constante inactiviteit van deze isovorm tijdens de ontwikkeling, suggereert dit wel dat de PDE4-D isovorm misschien nog wel meer dan de PDE4-B isovorm belangrijk kan zijn in leren en geheugen.

Hoofdstuk 7: In diverse knaagdier modellen voor leren en geheugen is aangetoond dat selectieve PDE remmers het lange termijn geheugen verbeteren. Er zijn echter maar zeer weinig studies waarin de effecten van PDE remmers op cognitie in gezonde primaten werd onderzocht. Dit hoofdstuk beschrijft de effecten van de PDE4 remmer rolipram en de PDE5 remmer sildenafil op 'object retrieval' (OR) prestatie. De OR taak is een taak die aangestuurd wordt door de prefrontale cortex en processen als aandacht en respons inhibitie worden ermee gemeten. Jonge volwassen Cynomolgus makaken werden getraind in de OR taak. Zowel rolipram als sildenafil verbeterden de prestatie in de OR test. Deze bevindingen versterken en vergroten het bewijs voor de cognitieverbeterende effecten van cAMP en cGMP via remming van PDEs. Hoewel de taakverbetering evident was kunnen we geen eenduidig onderliggende werkingsmechanismen en cellulaire paden aanduiden.

Hoofdstuk 8: In dit hoofdstuk worden de bevindingen van dit proefschrift bediscussieerd. Al met al geven de resultaten van de experimenten uit dit proefschrift overtuigend bewijs van de cognitie verbeterende eigenschappen van PDE remmers. De geheugenverbeterende effecten van PDE remmers werden aangetoond in ratten muizen en primaten. Er is bewijs dat er verschillende tijdsafhankelijke effecten van cAMP of cGMP selectieve PDEs zijn. Het lijkt zo te zijn dat cGMP met name betrokken is in vroege consolidatieprocessen en dat cAMP met name in late consolidatieprocessen betrokken is. De onderliggende mechanismen moeten nog volledig verklaard worden, maar cellulaire processen die in verband staan met LTP zijn een voor de hand liggende en plausibele mogelijkheid. Het cGMP/PKG/CREB proces voor vroege consolidatie processen en het cAMP/PKA/CREB proces voor late consolidatie processen zijn wellicht de meest waarschijnlijke mechanismen die ten grondslag kunnen liggen aan de gevonden geheugen verbeteringen. Verder zou het presynaptische NO/sGC/cGMP proces ook effecten kunnen hebben op het korte termijn geheugen, maar dat is tot heden nog niet onderzocht. Daarnaast kan cAMP ook betrokken zijn in korte termijn geheugen processen, waarschijnlijk via verhoging van neurotransmitter afgifte. Ten slotte wordt het ontrafelen van de onderliggende mechanismen van PDE remming nog moeilijker omdat is aangetoond dat E-LTP kan worden omgezet in L-LTP. In de toekomst zullen experimenten met specifieke antilichamen tegen PDEs uitsluitsel moeten geven over de pre- of postsynaptische localisatie 
van de PDEs en dit zou meer inzicht in de onderliggende werkingsmechanismen kunnen bieden. Recentelijk is in ons lab een specifiek PDE5 antilichaam ontwikkeld en de eerste immunohistochemische resultaten worden in de nabije toekomst verwacht.

PDE remmers, PDE5 remmers in het bijzonder, staan bekend om hun perifere effecten op vaatverwijding. Het is nog niet onomstotelijk aangetoond dat PDE remmers ook effecten hebben op de centrale doorbloeding en het centrale glucose metabolisme. In dit hoofdstuk wordt bediscussieerd waarom het op basis van de literatuur niet waarschijnlijk is dat onze geheugenverbeterende effecten van PDE remmers verklaard zouden kunnen worden door effecten op de doorbloeding.

Isovorm specifieke studies zijn veelbelovende nieuwe manieren om de onderliggende mechanismen van geheugenverbetering in diermodellen te onderzoeken. Genetische KO modellen voor PDE4 laten veranderingen in cognitie en depressie zien maar ontwikkelingsafwijkingen zouden de resultaten van deze experimenten kunnen vertroebelen. Nieuwe technieken zoals 'gen-silencing', zouden ons begrip van de onderliggende mechanismen van PDE remming en cognitie aanzienlijk kunnen verbeteren en kunnen leiden tot meer specifieke targets voor cognitieve verbetering. 



\section{DANKWOORD}




\section{DANKWOORD (ACKNOWLEDGEMENTS)}

De volgende personen wil ik bedanken voor hun steun, hulp en vertrouwen bij het volbrengen van mijn $\mathrm{AiO}$ periode het daaruit volgende proefschrift.

Prof Dr H.W.M. Steinbusch, promotor. Beste Harry, bedankt dat je me het laatste jaar als AiO hebt aangesteld binnen het instituut Hersenen en Gedrag, en voor alle advies en de goede raad betreffende mijn promotie en het mogelijke vervolg van mijn wetenschappelijke carrière, vooral de laatste maanden.

Dr A. Blokland, co-promotor. Beste Arjan, jou wil ik bedanken voor de fijne werkrelatie die we opgebouwd hebben. Je hebt me altijd vrijheid gegeven om mijn studies uit te voeren en te plannen zoals ik dat wilde en wanneer nodig altijd advies gegeven. Bedankt voor het vertrouwen dat je me hebt weten te geven om alles tot een positief einde te brengen. Ik heb enorm veel geleerd en ben erg gegroeid in mijn zelfstandigheid dankzij jou supervisie. Hopelijk zullen er in de toekomst mogelijkheden blijven om samen te werken.

Dr J. Prickaerts. Beste Jos, jij kwam pas vooral het laatste jaar op het toneel in mijn AiO periode en bent een enorme steun geweest voor mijn projecten. Vooral aan je adviezen en expertise op PDE gebied heb ik veel gehad. Jij hebt bijgedragen aan mijn wetenschappelijke bijschaving en hebt me vooral geleerd secuurder te zijn...de puntjes op de i, komen er nu steeds vaker dankzij jou. Ik hoop dat we ook in de toekomst collega's zullen blijven en nog langer actief mogen blijven in het veld van de PDE remmers op cognitie en affect.

Mijn paranimfen, Ayhan Sik en Roel Rutten. Ayhan, bedankt voor de fijne tijd op de afdeling. We zijn altijd collega's geweest en hebben lief en leed gedeeld. Naast collega's zijn we ook maatjes geworden en ik hoop dat we ook ondanks je nieuwe baan vrienden zullen blijven. Roel, bro, thanks for being there. De tijd dat je mijn kleine broertje was is allang niet meer. $\mathrm{Nu}$ zijn we echte vrienden en ik wil je bedanken dat je altijd voor me klaar staat. Als er iemand is die ik altijd alles kan toevertrouwen ben jij het. Bedankt dat jullie mijn paranimfen willen zijn en we gaan er een mooie promotie en een mooi feest van maken.

De kamergenoten, Linda, Eva, Jochen en Olga. Ik wil jullie van harte bedanken voor de steun tijdens mij n experimenten en adviezen bij de totstandkoming van dit proefschrift. Daarnaast natuurlijk ook voor de gezelligheid die bij ons op de kamer eigenlijk altijd wel dik in orde was. Ook de mensen die nu niet meer op de afdeling werken: Cindy, Laura en Marjo jullie wil ik toch bedanken voor de steun en gezelligheid op onze kamer. Hoop dat we ook na mijn promotie collega's/vrienden blijven.

De vakgroep NP, Jan de Vente bedankt voor de adviezen op het gebied van PDE5 en voor het plaatsnemen in de leescommissie van mijn proefschrift, Hellen en Marianne voor het afwe- 
gen van de talloze (haast) niet op te lossen substanties. Iedereen op de afdeling neuropsychologie en psychiatrie, het secretariaat NP, alle stagestudenten, jullie waren fijne collega's en ik wil iedereen bedanken die op welke manier dan ook geholpen heeft bij mijn proefschrift.

Dr Monique Mulder, bedankt voor de samenwerking met de APP muizen in het verleden en wellicht ook in de toekomst. Tim van Mierlo, je hebt een groot deel van je stage bij mij gedaan en we hebben fijn samengewerkt, bedankt en wellicht worden we weer collega's in de toekomst. Dr Franz-Josef Van der Staay. Bedankt voor de samenwerking en de twee mooie publicaties die hieruit zullen volgen. Ik hoop in de toekomst vaker projecten samen te kunnen uitvoeren.

De mensen van de Centrale Proefdier Voorzieningen (CPV) en in het bijzonder Richard, Harry en Allard. Bedankt voor de ondersteuning, verzorging en de assistentie bij de vele gedragsstudies die we in Maastricht hebben uitgevoerd.

Dr Rudy Schreiber, Dear Rudy, I want to thank you for the opportunity you gave me to come to California for a 7 month internship at Roche Palo Alto. I have learnt a great deal here and it was a wonderful experience. Of course, I would like to thank all the people I worked with in the CNS department of Luca Santarelli at Roche Palo Alto. Special thanks go out to my supervisors there: Tanya Wallace and Jeff Vivian. Also in Palo Alto a lot of people helped me with the experiments, Linda Hedley, the research assistants (Min, Sony, Jenny, Kristine, Melissa, July and Bertha), and the people from the animal facilities (Fai).

Finally, a big thank you to the people that made my stay in California outside work at Roche a time to never forget. My roommate David Longwell (and his poker crew), my sparring buddies at the Kung Lee Kickboxing gym in San Jose, and my Asian homeboys Min Jun, Brian Lee and the rest of the clan Henri, Phil, Bo, Gareth, Dan and James.

Natuurlijk wil ik mijn meisje Esmeralda bedanken. Schat, je hebt me altijd gesteund in mijn promotie, we hebben net samen ons nieuwe huisje klaar en we gaan een heel mooie toekomst tegemoet. Ik wens je veel succes toe met de afronding van de opleiding tot GZ psycholoog en ik hoop dat ik er net zo voor jou kan zijn als jij er voor mij bent geweest. Daarnaast wil ik mijn vader, Kitty, oma en Roel en mijn schoonouders Jeu en Ria bedanken omdat ze er altijd voor me zijn. Jim, enorm bedankt voor het ontwerpen van de kaft en de uitnodigingen.

Ten slotte, mijn vrienden die ik al ken sinds de kleuterschool en vaak zijn het nog steeds een stel kleuters. Job, Kevin, Michel, Sebas en ook Dave, Tim, Han, Jos, Mark en Lars. Dat we nog lang vrienden mogen blijven en dat ik nog veel geld van jullie mag winnen met pokeren.

Veel mensen hebben op de een of andere manier bijgedragen aan dit proefschrift. Het kan zijn dat ik bepaalde personen vergeten ben. Ik wil hierbij iedereen bedanken die een bijdrage heeft geleverd aan de totstandkoming van mijn boekje. 


\section{Publications}




\section{Publications}

Rutten, K., Prickaerts, J. \& Blokland, A. Rolipram reverses scopolamine-induced and time dependent forgetting in object recognition by different mechanisms of action. 2006. Neurobiology of Learning and Memory, 85, 132-138.

Rutten, K., de Vente, J., Sik, A., Markerink-van Ittersum, M., Prickaerts, J. \& Blokland, A. The selective PDE5 inhibitor, sildenafil, improves object memory in Swiss mice and increases cGMP levels in hippocampal slices. 2005. Behavioral Brain Research, 164, 11-16.

Rutten, K., Prickaerts, J., Hendrix, M., van der Staay, F.J., Sik, A. \& Blokland, A. Time dependent involvement of cAMP and cGMP in consolidation of object memory: studies using selective phosphodiesterase type 2, 4 and 5 inhibitors. European Journal of Pharmacology, in press 2006.

Rutten, K., Smits, L., Lieben, C. \& Blokland, A. The PDE4 inhibitor rolipram reverses object memory impairment induces by acute tryptophan depletion. Psychopharmacology, in press 2007.

Hoff, E., Blokland, A., Rutten, K., Steinbusch, H., van Oostenbrugge, R. Dissociable effects in reaction time performance after unilateral cerebral infarction: a comparison between the left and right frontal cortices in rats. 2006. Brain Research, 1069, 182-9.

Blokland, A., Rutten, K. Prickaerts, J. Analysis of spatial orientation strategies of male and female Wistar rats in a Morris water escape task. 2006. Behavioral Brain Research, 171, 216-24.

\section{PUBLICATIONS IN PROGRESS}

Van der Staay, F.J., Rutten, K., Erb, C., \& Blokland, A. Effects of MK-801 on learning and memory in rats and mice. European Neuropsychopharmacology, submitted.

Rutten, K., Works, M., Blokland, A., Santarelli, L. \& Wallace-Boone, T. Behavioral effects of PDE4-D and PDE4-B knock-out mice in models of learning and memory. (Awaiting clearance from Roche).

Rutten, K., Basile, J., Blokland, A. \& Vivian, J. Selective PDE inhibitors sildenafil and rolipram improve object retrieval performance in unimpaired adult cynomolgus macaques. (Awaiting clearance from Roche). 


\section{Curriculum vitae}


Kris Rutten was born on September 18th 1980 in Kerkrade and grew up in Landgraaf (Limburg). After his VWO graduation at Eijkhagen College in Landgraaf, he started in 1998 the study of Health Sciences at Maastricht University. After the first year he switched from Health Sciences to the study of Biological Psychology (neuropsychology) in 1999, also at Maastricht University. He graduated in 2003 after a six months research internship at the Department of Psychiatry and Neuropsychology. After his graduation he stayed at this department to work as a research assistant in behavioral pharmacology, testing novel compounds for the pharmacological industry (BAYER and Roche). In 2004 he started as a PhD student on the project described in this thesis at the Department of Psychiatry and Neuropsychology (Intstitute Brain \& Behaviour) at Maastricht University. For his research project, he had the opportunity to visit the department of Central Nervous System (CNS) Bioscience at Roche Pharmaceuticals in Palo Alto, California, USA for seven months.

Kris Rutten werd geboren op 18 september 1980 in Kerkrade en groeide op in Landgraaf (Limburg). Na het behalen van zijn eindexamen VWO aan het Eijkhagen College in Landgraaf, begon hij in 1998 met de studie gezondheidswetenschappen aan de Universiteit Maastricht. Na het eerste jaar stapte hij in 1999 over van gezondheidswetenschappen naar de studie Biologische Psychologie ook aan de Universiteit Maatricht. Na een onderzoeksstage van zes maanden bij de afdeling Psychiatrie en Neuropsychologie haalde hij in 2003 zijn doctoraal diploma in de Biologische Psychologie (neuropsychologie). Hierna, bleef hij werkzaam op deze afdeling als onderzoeksassistent met als taak nieuwe drugs voor de farmacologische industrie (BAYER en Roche) te testen. In 2004 begon hij als assistent in opleiding (AiO) bij de afdeling Psychiatrie en Neuropsychologie (Instituut Hersenen en Gedrag). In deze periode werd het onderzoek verricht dat beschreven staat in dit proefschrift. Tijdens zijn AiO periode kreeg hij de gelegenheid om de CNS afdeling van Roche Pharmaceuticals voor zeven maanden te bezoeken in Palo Alto, Californië, VS. 
